\title{
CITY OF PATTERSON SUSTAINABILITY PLAN
}

\author{
A Thesis \\ presented to \\ the Faculty of California Polytechnic State University, \\ San Luis Obispo
}

In Partial Fulfillment

of the Requirements for the Degree

Master of City and Regional Planning in the College of Architecture

by

Colin B. Clarke

June 2009 
(C)2009

Colin Brian Clarke

ALL RIGHTS RESERVED 


\section{COMMITTEE MEMBERSHIP}

Title:

Author:

Date Submitted:
City of Patterson Sustainability Plan

Colin B. Clarke

June 2009

\section{MAster's THEsis / PROFEssional PROJECT COMMITTEE}

Committee Chair: $\quad$ Adrienne Greve, Assistant Professor

Committee Member: Dave Moran

Senior Associate Planner

Crawford Multari \& Clark Associates

Committee Member: $\quad$ Paul Wack, Professor 


\section{ABSTRACT}

Title: City of Patterson Sustainability Plan

Author: Colin B. Clarke

This Master's Thesis / Professional Project is a Sustainability Plan developed for the City of Patterson, California. The Patterson Sustainability Plan (PSP) was developed concurrently with the General Plan Update, and will be presented to the City for adoption within a year. The Sustainability Plan will help inform decision-making by way of its Goals and Actions for implementation to improve community sustainability. Before the plan was developed, background research was conducted that included a Best Practices Review to assess what other cities are doing to address sustainability, a Needs Assessment to evaluate existing conditions in Patterson and determine its unique strengths and challenges to improving sustainability, and a Policy Audit which includes an inventory and analysis of existing General Plan goals, objectives, policies, and programs supporting sustainability. 


\section{ACKNOWLEDGEMENTS}

This work would not have been possible without the support and encouragement of my supervisor at Crawford Multari \& Clark Associates (CMCA), Dave Moran, and my Committee Chair, Dr. Adrienne Greve, whose thoughtful advice often served to give me a sense of direction throughout the process of developing this Thesis / Professional Project. I would also like to express my gratitude to Rod Simpson, Community Development Director for the City of Patterson, and Sonia Delgado, Administrative Manager of the Public Works Department, for their assistance in gathering information. I am also deeply grateful to Chris Clark of CMCA, for the opportunity, trust, and support that he gave me in order for me to take on this project. I cannot finish without saying how grateful I am to all of my family and friends who extended their support and understanding throughout this process. Lastly, and most importantly, I wish to thank my parents, Brian and Paula Clarke. They have always supported and encouraged me to do my best. 


\section{TABLE OF CONTENTS}

THESIS INTRODUCTION 1

THESIS CONCLUSION ............................................. 12

BIBLIOGRAPHY ............................................................ 17

\section{CitY OF PATTERSON SUSTAINABILITY PLAN}

EXECUTIVE SUMMARY .........................................

\section{INTRODUCTION}

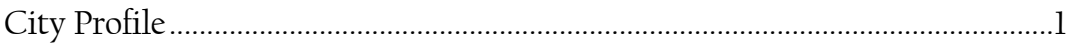

Purpose of the Sustainability Plan ...............................................................................

Climate Change and Sustainability ..............................................................2

Regulatory Framework ...................................................................................

How the Plan Was Prepared..........................................................................

Patterson's Principles of Sustainability ........................................................

How the Plan is Organized ............................................................................... 6

How to Use This Plan ...................................................................................... 6

Relationship to Other Policy Documents ....................................................

\section{SUSTAINABILITY FOCUS AREAS}

LAND USE \& TRANSPORTATION .......................................... 8

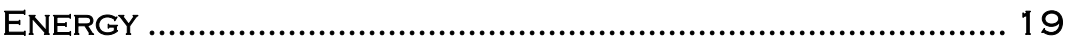

WASTE REDUCTION \& RECYCLING ....................................... 28

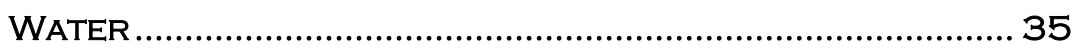

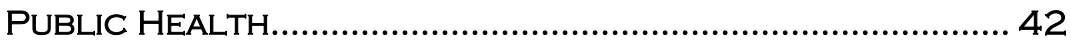

SUSTAINABLE ECONOMIC DEVELOPMENT ............................. 49

OUTREACH \& AWARENESS ................................................... 54

PhASING, IMPLEMENTATION \& FUNDING .............. 61

APPENDIX

BEST PRACTICES REVIEW ................................................. A-1

NEEDS ASSESSMENT \& POLICY AUdIT.................................... B-1

ADDITIONAL ACTIONS FOR CONSIDERATION........................... C-1

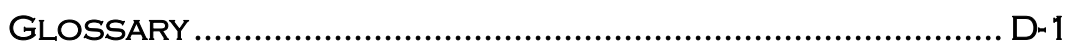




\section{THESIS INTRODUCTION}

Cities nationwide are increasingly taking up the elective task of addressing the concept of sustainability. Sustainability is defined as "meeting the needs of the present generation without compromising the ability of future generations to meet their needs" (World Commission on Environment and Development 1987). A sustainable community is one where natural resources are used only at a rate that can be replenished by nature (i.e. renewable resources), and one where long-term community health and the quality of life for local residents is maintained and continuously being improved. When focusing on community sustainability, cities want to ensure that future growth does not come at a cost of public health or the natural environment. Sustainable development balances economic prosperity, environmental protection, and social equity. Local jurisdictions have the opportunity to lead by example, demonstrating to residents and businesses the benefits of improving sustainability, while strengthening the economy. Achieving sustainability requires a focus on policy that incorporates numerous innovative strategies in a broad array of topics. For example, promoting local agriculture can reduce reliance on distant food purchasing requiring long truck trips, promote organic food consumption, increase the viability of farming as an occupation, protect agricultural land from urban development, and improve the sustainability of the local economy. Other examples of improving sustainability include maintaining a healthy urban forest to help improve air quality, and a system of parks, open space, and pathways for increased connectivity and recreational opportunities, promoting alternative modes of transportation and personal physical fitness.

The City of Patterson, California is conducting a comprehensive General Plan update, making this an ideal opportunity to incorporate principles of sustainability, both to comply with state and federal law, and to lead by example. The purpose of this Master's Thesis / Professional Project is to develop a Sustainability Plan for the City of Patterson. The Patterson Sustainability Plan (PSP) will help inform decision-making by way of its Goals, and propose Actions for implementation to achieve sustainability. 
I begin this thesis describing the geographical context and providing a brief background on the City of Patterson, including why the City was chosen for this project. To provide context for the plan content and the eventual role of the plan in Patterson, I discuss the relationship between sustainability and climate change, the purpose of the Sustainability Plan, the method that went into developing the Plan, and how the Plan is organized. In the Thesis Conclusion, I explain lessons learned from the experience of developing the document, how well the chosen method fit the project, and the extent to which the knowledge gained from this experience will be applicable elsewhere.

\section{CITY PROFILE}

Patterson is a California community of about 21,000 people (an $83 \%$ increase, or nearly double the 11,600 residents counted in the 2000 Census) located approximately 20 miles southwest of Modesto (the County seat), in the western part of Stanislaus County, in the San Joaquin Valley. The nearest community is Westley, six miles northwest of Patterson. The self-proclaimed "Apricot Capital of the World" is adjacent to Interstate-5 and three miles west of the San Joaquin River. Highway-33 runs northwest-southeast along $2^{\text {nd }}$ Street, separating the downtown core from industrial uses to the east. Incorporated in 1919, Patterson is a small, rural town of about three square miles, surrounded by agricultural land, and a history of apricots, almonds, walnuts, dry beans, tomatoes, broccoli, spinach, peas, and melons. The City derives much of its economic vitality from agriculture and food processing, but it also has a large and expanding business park. Patterson's street layout, inspired by the metropolitan areas of Paris, France and Washington, D.C., features a circular format in the central district surrounded by radiating streets. The City is also known for its tree-lined main thoroughfares (eucalyptus, sycamore, and palm trees). In recognition of its agricultural heritage, the City is home to the annual Apricot Fiesta in June. 


\section{WHY PATTERSON?}

As a Master's Candidate wanting to study the application of sustainability on a citywide level, I needed to work in a community experiencing fast growth to be able to make a difference and have the ability to positively influence future growth, a community small enough to ensure the feasibility of completing the project within a year, and a community already in the process of updating its General Plan. The City of Patterson meets all three of these criteria.

It is difficult to integrate principles of sustainability in cities in California's Central Valley because of the increasing pressure for economic growth to support its citizens. I saw this as a huge opportunity to be able to affect positive change in an area that greatly needs to improve its sustainability before it continues to grow even further, especially if California is going to maintain its position as the eighth largest economy in the world, to which agriculture in the Central Valley contributes enormously. Far from build-out, Patterson is a growing Central Valley community characterized by rapid housing growth from the mid-1990s until 2006, when housing growth slowed down nationwide due to an economic downturn not seen since the Great Depression. Since 1990, the City's land footprint increased 250 percent, and "no city in the region sprawled as aggressively as Patterson;" the second-most "land-hungry" city was Turlock, which extended its footprint 74 percent (Modesto Bee 3/29/2009). As part of the General Plan Update currently underway, the Planning Commission in Patterson envisions a population of 83,000, nearly quadrupling its current population, by 2048. The City's elected officials decided to opt out of the adoption of strategies recommended by the San Joaquin Valley Regional Blueprint Planning Process, an innovative, eight county planning exercise intended to provide for sustainable growth through 2050. City officials prefer to "keep local control." By developing the City's own Sustainability Plan, there is a better chance to positively influence future growth in Patterson and plan adoption may come more easily. 
Despite its conventional sprawling (land-consumptive) development pattern, Patterson ranked second overall for "smart growth" in a survey of 60 communities in the San Joaquin Valley (Modesto Bee 2008). Because the City already has experience adopting "smart growth" principles, Patterson may be more willing to adopt a Sustainability Plan than other cities in the Central Valley. The Modesto Bee newspaper, with the help of planning experts from October 2007 to January 2008, polled 68 planning directors from the eight-county San Joaquin Valley, evaluating planning policies (not the reality on-theground) for widely-accepted smart growth principles including public outreach, development, fees, transportation \& infrastructure, design, amenities, affordability, agriculture \& open space, and economic development. Patterson ranked second overall, with a score of $77.25 \%$, behind Oakdale (79.5\%). According to the study, no city scored higher in design (100\%), developer fees (88\%), and affordability (87\%). The study found the City's comprehensive landscaping, street furniture, building, thematic and color design standards to be "second to none," but the City could "feel pain in the future, however, without water and sewer improvements." According to an October 2008 Modesto Bee article, Patterson "recognized its mistakes it made with some developments" and amended its General Plan in 2004 to include policies similar to those neo-traditional development principles embraced by Oakdale and Turlock.

Patterson is a small town surrounded by prime farmland, with great potential for compact growth and an improved jobs/housing ratio, thereby enhancing the ability to walk or bicycle - both aspects which improve community sustainability. According to the US Census, the average one-way commute to work in 2000 was more than 41 minutes for residents of Patterson, compared to 27 minutes for workers in the overall County of Stanislaus. In 2000, at least 70 percent drove a car alone to work, while only 24 percent carpooled (US Census). Nearly 77 percent of workers had jobs outside Stanislaus County (US Census). The Commuter Survey conducted in early 2004 revealed 79 percent of respondents naming a San Francisco Bay Area location (San Jose and Livermore were mentioned the most) as their commute destination and an average one-way commute time of almost 78 minutes. 
Lastly, I was given the opportunity to develop the Patterson Sustainability Plan for the Master's Thesis / Professional Project because I work as a Planning Intern at Crawford Multari \& Clark Associates (CMCA), the City's consultant performing the General Plan Update. The timing was ideal because the Sustainability Plan could be developed concurrently with the General Plan Update, thereby informing the City's broader policies in addition to proposing specific implementation Actions. My position at CMCA allowed me access to a considerable amount of information and resources regarding specific existing conditions in Patterson that would have taken me months to obtain otherwise, had I not been able to work alongside the City's General Plan consultant. Moreover, by attaining buy-in from the City's General Plan consultant, the chances of the Patterson Sustainability Plan actually being implemented in the near future, are improved, especially given the advantage of having institutional knowledge of the local political climate.

\section{Climate Change AND SUSTAINABILITY}

Sustainability is an extremely broad concept, with several aspects to which it subscribes, from compact growth to energy efficiency and a "green" economy, to human and community health, and the conservation of natural resources. These topics under sustainability are interrelated. Greenhouse gas (GHG) emissions, a newly-recognized air pollutant, is another aspect under the realm of sustainability. Climate change mitigation requires the reduction of GHG emissions and adaptation to forthcoming changes. Both mitigation and adaptation to climate change influence the elements of sustainability.

Global warming is characterized by rising temperatures due to the greenhouse effect, which is known to be primarily caused by greenhouse gas emissions from vehicles, buildings, power plants, and other manmade sources - rather than natural variations in climate (PEW Center on Global Climate Change 2009). The impact of global warming is known as climate change, increasingly viewed with consensus by the majority of leading scientists as a serious issue requiring immediate attention from those who shape 
policy. A holistic approach to improving sustainability can slow the rate at which climate change intensifies.

Climate change is a global problem with local consequences for sustainability. Rising temperatures and longer, more frequent heat waves can contribute to increased air pollution (smog) and a variety of public health issues, increasing asthma and respiratory illnesses due to higher ozone levels (in an Air District already known to have some of the worst air quality in the nation). The number of heat wave days per year may increase two-fold (or more), with more days of poor air quality and high ground-level ozone concentrations, meaning more stress on electricity and water supplies, an increase in heat-related deaths, and greater strain on those with respiratory and cardiovascular diseases. On average, summers will likely be hotter and drier, with wildfires, droughts, and severe storms increasing in frequency and intensity. Stanislaus County averages only 12 inches of rainfall each year. Climate change may result in changing rainfall patterns, overwhelming waterways in periods of flooding and making severe droughts far more frequent and long-lasting. The agricultural industry also may be disrupted by shifts in temperature and precipitation patterns, impacting the sustainability of the local economy. Given that the effects of climate change will adversely impact Patterson, it is in the City's best interest to promote principles of sustainability.

\section{PURPOSE OF THE SUSTAINABILITY PLAN}

The Patterson Sustainability Plan sets forth specific actions to improve the City's overall sustainability now and in the future. It recommends changes to the City's current operational and decision-making practices, as well as changes the private sector can make (voluntary or otherwise). The objective of the Plan is to preserve the unique, small rural town character, minimize adverse environmental impacts, and promote efficient use of land, materials, energy, water, and other finite resources, but it is also to improve public health and the quality of life in Patterson. The Plan provides measurable targets (Progress Indicators) to regularly assess the effectiveness of these efforts, and also responds to recent state and 
federal legislation aimed at reducing the effects of local decision-making on climate change. The following Focus Areas are addressed: Land Use \& Transportation, Waste Reduction \& Recycling, Energy, Water, Public Health, Sustainable Economic Development, and Outreach \& Awareness.

There is a need for policies and programs that demonstrate leadership and educate residents and businesses about sustainability, given the many benefits that can be derived from the Actions proposed in this Plan. For example, by preserving agricultural land and promoting decentralized food purchasing, local farming will remain a feasible livelihood, strengthen the regional economy, improve public health, and encourage compact growth. It is important for Patterson to preserve its agricultural heritage and retain the City's identity as the Apricot Capital of the World. By attracting more jobs to Patterson and encouraging a more dense urban form as an alternative to sprawl, the City can reduce the need for a long commute to work and increase the viability of using alternative modes of transportation such as walking, bicycling, and transit. This will help reduce the use of fossil fuels while achieving substantial reductions in greenhouse gas emissions, resulting in cleaner air. Measures for energy efficiency, waste reduction, and water conservation reduce the need for costly new infrastructure, protect natural resources, help ensure a reliable water supply, and result in cost-savings for residents, businesses, and the City. Ultimately, these Actions can fulfill the City's responsibility to maintain a higher quality of life for current and future residents.

\section{METHOD}

Because planning for sustainability is relatively new, the first step in the preparation of the Patterson Sustainability Plan was the Best Practices Review. It identifies planning practices that support sustainability, derived from Sustainability Plans, Climate Action Plans, and General Plan Elements from multiple jurisdictions that incorporate principles of sustainability. "Best practices" are goals, objectives, policies, and programs that provide effective strategies for water conservation, energy efficiency, compact urban growth, jobs/housing balance, waste reduction and recycling, carbon sequestration, improved air 
quality, and outreach $\&$ awareness. While there are many quality plans that have been adopted over the past few years, only a few were selected for innovative strategies to achieve greater sustainability. The cities chosen are generally from California, but cities from around the nation (e.g. Seattle) with a strong reputation and initiative in successfully moving toward sustainability were also studied. Some plans have stronger, more comprehensive actions in the Waste Reduction \& Recycling focus area, for example, while others have a more complete section on Agricultural Preservation. The City of Fresno's Plan was important for review because it has many similar characteristics when compared to the City of Patterson, such as the continuing outward urban sprawl pattern, contributing to the loss of agricultural lands. Not all strategies being implemented elsewhere are appropriate for Patterson. However, some of the approaches were able to be adapted to work in Patterson, while new ones were crafted to address specific issues unique to Patterson. The following documents were reviewed:

\section{Sustainability Plans}

- Sacramento Creating A Sustainable City: Implementation Plan (February 2008)

- Burbank Sustainability Action Plan (January 2008)

- Fresno Green: The City of Fresno's Strategy for Achieving Sustainability (May 2008)

- City of Santa Monica Sustainable City Plan (October 2006)

- City of Pasadena Green City Action Plan (2006)

Sustainability Element of the General Plan

- City of Grand Terrace Sustainable Development Element (January 2008 Draft)

- Boulder County Comprehensive Plan Sustainability Element (May 2007)

- City of Benicia Community Development and Sustainability Element (1999)

Sustainability Throughout the General Plan

- Marin Countywide Plan (November 2007)

Climate Action Plans

- City of Los Angeles: Green LA - An Action Plan to Lead the Nation In Fighting Global Warming (May 2007)

- Meeting the Kyoto Challenge: Seattle Climate Action Plan (September 2006)

- San Francisco Climate Action Plan (September 2004) 
Second, a Needs Assessment was conducted to evaluate existing conditions in Patterson. It discusses "Community Strengths Promoting Sustainability" and "Challenges To Improving Sustainability." The following documents, among others, were reviewed:

- $\quad$ Patterson General Plan (2004)

- Patterson Bicycle Master Plan (2001)

- Patterson Commuter Survey (March 2004)

- Patterson Community Design Guidelines (October 2002)

- Patterson Non-Potable Water Master Plan and Feasibility Study (July 2008)

- Patterson Urban Water Management Plan (December 2006)

- Villages of Patterson Development Plan EIR (2006)

- Stanislaus County General Plan (1994)

- Stanislaus County Non-Motorized Transportation Plan (September 2008)

- Stanislaus County Visioning Project 2000 (January 2002)

- California Farmland Conversion Report (December 2006)

The Policy Audit includes an inventory and analysis of existing General Plan goals, objectives, policies, and programs supporting sustainability. Major areas in need of policy change were identified so the City could focus its efforts. The best practices were analyzed to determine which ideas, approaches, and techniques can be applied in Patterson, given careful consideration of the City's characteristics including current land use, urban form, and geographical context.

Best Practices Review

What Other Cities Are Doing to Address Sustainability

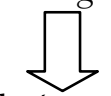

Needs Assessment

Existing Conditions in Patterson

(Strengths \& Challenges to Improving Sustainability)

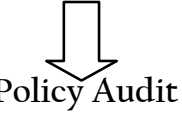

What Policies Patterson Has/Needs

Principles of Sustainability What Patterson Should Focus On

Sustainability Plan

Goals and Actions, Progress Indicators, and Near-Term Phasing 
Following the Best Practices Review and the Needs Assessment \& Policy Audit, I developed Patterson's Principles of Sustainability to help guide preparation of the Sustainability Plan.

\section{HOW THE PLAN IS ORgANIZED}

The Patterson Sustainability Plan consists of an Executive Summary, an Introduction, six Sustainability Focus Areas, and a chapter for overall Outreach \& Awareness:

\section{Land Use \& Transportation}

2. Energy

3. Waste Reduction \& Recycling

4. Water

5. Sustainable Economic Development

6. Public Health

7. Outreach \& Awareness

Each chapter begins with a brief introduction and lists Patterson's Opportunities \& Constraints to improving sustainability, a summary of the findings of the Needs Assessment. Strengths and Opportunities are aspects of Patterson that promote sustainability, while Constraints are aspects of Patterson that may hinder progress toward sustainability. "Recommendations" are followed by Goals, Actions, Progress Indicators, and Near-Term (within five years) Phasing \& Implementation. A Goal is a general direction, or a vision for sustainability. Actions are statements that guide implementation to achieve Goals. Progress Indicators are performance assessment tools that measure how well the City is achieving its sustainability goals. The Phasing \& Implementation table shows Actions recommended for the Near-Term (within five years of plan adoption). Actions have been prioritized based on the degree that the City has the ability to influence implementation, the degree to which they promote long-term community and environmental sustainability, and the extent that residents will benefit in terms of costsavings and improved quality of life and public health. 
Following the seven main chapters of the Plan is a section on Phasing, Implementation \& Funding, discussing potential funding sources and the proposed Near-Term Phasing to occur within the first five years following adoption of the Plan. The Appendix consists of the Best Practices Review, Needs Assessment \& Policy Audit, Additional Actions for Consideration, and Glossary. 


\section{THESIS CONCLUSION}

Many lessons can be taken away from the process of developing a Sustainability Plan for an entire city surrounded by agriculture and the pressure to expand outward. In only nine months, an idea was taken from the conceptual stage in a few brainstorming meetings to a final product. I learned very quickly that the task of developing a Sustainability Plan, with all the background research that is required, is nothing short of a sizeable undertaking. I was warned from the beginning that it would be a great deal of work, but I was eager to take on the challenge. I end this thesis describing lessons learned about options for adoption, and how this experience is relevant to the planning profession at large. I also discuss lessons learned from the process, which proved to be particularly iterative, appropriate language and content of a plan, and general knowledge gained. Finally, I discuss the next steps for Patterson.

\section{OPTIONS FOR ADOPTION}

As part of the Best Practices Review, I examined options for adoption. Because cities have taken several approaches when developing policies and programs to improve sustainability, it was not immediately clear what was the best choice for Patterson. I learned the difference between a stand-alone Sustainability Plan and incorporating sustainability into a General Plan, and the analysis that goes into deciding which is the best alternative. Ultimately, the decision was to create a free-standing Sustainability Plan. By necessity, a Sustainability Plan is an adaptive document because Progress Indicators are regularly monitored and evaluated. In addition, priorities change as technology improves and funding becomes more readily available, so it is advantageous to adopt a stand-alone Sustainability Plan to ease the update process. The option of a stand-alone Plan is beneficial so that the City can include specific implementation measures (Actions), beyond the broad sustainability goals or policies typical in a

General Plan. However, it is imperative for the City also to update its General Plan to incorporate said broad goals and policies, to guide decision-making on a policy level. 
From the experience developing a Sustainability Plan for the City of Patterson, other cities can observe the importance of concurrently update the General Plan as they adopt principles of sustainability and specific implementation Actions. It is especially important because it eases the process of ensuring compatibility and consistency between the General Plan and the Sustainability Plan.

\section{THE PROCESS}

I learned a great deal about the plan-making process, bringing theory to practice in Cal Poly's renowned "learn by doing" mantra, taking what I have learned in the classroom and applying it to a real-world situation. My experience developing the Land Use Element for the 2030 Community Plan (comparable to a General Plan) for the City of Guadalupe over six months, where I worked with a partner to formulate goals, objectives, policies, and programs, greatly informed how I approached the task of writing an entire plan. One stark contrast between the two processes in plan-making, is that the Guadalupe planning process involved a series of five community workshops that helped gain input from citizens and other stakeholders, while for Patterson, because of geographical and time constraints, among other factors, I was not able to conduct outreach or gain any public input, apart from a few conversations with a personal friend who is a resident of Patterson. Without the benefit of public input, I had to perform a great deal of research and work very closely with Dave Moran, my colleague at Crawford Multari \& Clark Associates, who has a great deal of institutional knowledge about the City of Patterson given his seventeen years working as their consultant.

One of the main lessons learned from the experience developing the City of Patterson Sustainability Plan was to constantly ask myself, "how do we make Patterson more sustainable?" The method used in this plan-making process was generally successful. However, at times, I found myself caught up in the "best practices," when I should have been focusing on the client's individual, and unique, needs. I soon realized that I needed to ask myself whether Goals and Actions were realistic, in light of political, financial, and phasing and implementation constraints. Because of these constraints, the process proved to be 
particularly iterative, and the final product transformed constantly. While developing the Goals and Actions for the Plan, I learned the extent to which the organization of plan contents was iterative as well. The subject matter in each chapter, and the order of such content, constantly evolved throughout the process for reasons of clarity, brevity, and relevance. Goals and Actions were streamlined, moved around, or omitted, because the City has no direct control over some Actions, e.g. agricultural preservation surrounding the City, but in the jurisdiction of Stanislaus County.

\section{APPROPRIATE LANGUAGE $\&$ CONTENT}

I learned a great deal about the appropriateness of language and content in a public document. For example, I learned to minimize the citation of other plans within the Patterson Sustainability Plan and cite the original source instead (e.g. buildings nationwide account for $70 \%$ of electricity use). While conducting the Policy Audit, I realized that a General Plan Policy Document does not always have implementation measures for each policy because General Plan policies are simply meant to guide the decision-making process. As such, not all policies will have an implementation measure. After all, a General Plan is "general." Because of this, I gained inspiration to shape the Patterson Sustainability Plan as more of an Action Plan, than a policy document. I developed Goals and Actions to improve sustainability in Patterson, while collaborating with Dave Moran and David Grim at Crawford Multari $\&$ Clark Associates to "inform" the General Plan Update simultaneously underway with more broad goals and policies. While developing the Sustainability Focus Area chapters, I learned the relationship between goals, objectives, policies, programs, actions, targets, and indicators. I also learned the importance of using professional judgement to decide whether to "recommend," or "require," an action. Similarly, it was important to carefully consider whether to use "should," "shall," "may," "will," and "encourage." I also learned how to clearly articulate the relationship between sustainability and climate change, sustainability and public health, and air quality and public health (e.g. clearly distinguishing air pollutants such as ozone and particulate matter from greenhouse gas emissions). 


\section{KNOWLEDGE GAINED}

Throughout the process of developing the City of Patterson Sustainability Plan, I gained a variety of new knowledge in a wide array of topics related to sustainability. For example, I learned a great deal about water resources, renewable energy, and air quality - among numerous other topics I had not previously studied. This new knowledge is, without a doubt, applicable elsewhere. Whether I choose to work for a City, County, regional planning agency, or private firm (planning or otherwise), I have very specific knowledge of what it takes to achieve sustainability. As such, I have gained a potential specialty, or niche, in the planning profession and will be able to help other organizations improve their ability to be sustainable.

\section{NEXT STEPS}

The hope is that CMCA will now present this Patterson Sustainability Plan to the City as the General Plan Update process is completed. The Goals and Actions identified in the Sustainability Plan complement, and are intended to help implement, the policies and programs of the City's proposed General Plan. The Plan provides a range of strategies to ensure principles of sustainability are appropriately integrated into City policies, services, daily operations, and decision-making. The Plan is also intended to encourage residents and businesses to do their part in helping to achieve a more sustainable city. It is meant to be a working strategy document that will continue to evolve. The Sustainability Plan should be reviewed on an annual basis (through the proposed Annual Progress Report), measuring successful implementation, evaluating progress, and updating Actions and priorities due to knowledge of new best practices and performance indicators brought on by improved technology, availability of funding, or other factors. The City should establish an interdepartmental working group (Green Team/Sustainability Task Force) and an external advisory group to secure funding sources and help implement the Plan. 
The City should first focus primarily on City operations to lead by example. Actions that have low cost, or no cost, can be implemented immediately with existing resources. The most cost-effective Actions for the City, its residents, and private businesses should be selected for near-term implementation based on an analysis of the associated costs and benefits (financial, environmental, and social), with an emphasis on investing in Actions delivering multiple benefits (e.g. cost savings, and improved quality of air and water).

Partnerships and local community involvement will be crucial to the success of the Sustainability Plan. Achieving sustainability will require the City's leadership, and participation by residents and businesses. Outreach and awareness programs should be instituted to show residents and businesses what they can do to achieve a more sustainable future. 


\section{BIBLIOGRAPHY}

\section{GENERAL BACKGROUND}

American Planning Association. (2008, April 27). Policy Guide On Planning \&

Climate Change. Retrieved November 14, 2008 from

http://myapa.planning.org/policyguides/pdf/climatechange.pdf

American Planning Association. (2009). Planners Energy and Climate

Database. Retrieved May 24, 2009 from

http://www.planning.org/research/energy/database/

California Climate Change Center. (2006, July). Our Changing Climate:

Assessing the Risks to California. Retrieved November 14, 2008 from

http://www.energy.ca.gov/2006publications/CEC-500-2006-077/CEC-500-2006-077.PDF

Climate Change Task Force, California Chapter: American Planning

Association. (2007, September). Planning Policy Principles for Climate Change Response.

Retrieved November 14, 2008 from

http://www.calapa.org/attachments/contentmanagers/71l/ClimateChange.pdf

Field, Christopher B. et al. (1999, November). Confronting Climate Change in

California: Ecological Impacts on the Golden State. A Report of The Union of Concerned

Scientists and The Ecological Society of America. Retrieved September 18, 2008 from

http://www.ecologicalsocietyofamerica.org/science resources/DocumentFiles/ca report.pdf

Office of the California Attorney General. (2008, October 17). Global

Warming. Retrieved October 17, 2008 from http://ag.ca.gov/globalwarming/

Office of the California Attorney General. (Date Unknown). Global Warming

Impacts in California. Retrieved October 17, 2008 from http://ag.ca.gov/globalwarming/impact.php

Office of the California Attorney General. (2007). The Facts About Global

Warming. Retrieved October 17, 2008 from http://ag.ca.gov/globalwarming/facts.php

Office of the California Attorney General. (2008, September 26). The California

Environmental Quality Act: Addressing Global Warming Impacts at the Local Agency Level.

Retrieved from http://ag.ca.gov/globalwarming/

Pew Center on Global Climate Change. (2008). Climate Change 101 Overview.

Retrieved November 26, 2008 from

http://www.pewclimate.org/docUploads/1ll4 OverviewFinal.pdf

United Nations Green Cities Declaration And Urban Environmental Accords. (2006).

U.S. Environmental Protection Agency. (2009, April 22). Climate Change:

Effects. Retrieved May 24, 2009 from http://www.epa.gov/climatechange/fq/effects.html 
U.S. Environmental Protection Agency. (2008, August 20). Green Communities. Retrieved October 16, 2008 from http://www.epa.gov/greenkit/

U.S. Environmental Protection Agency. (2008, October 9). Sustainability. Retrieved October 16, 2008 from http://www.epa.gov/sustainability/

U.S. Conference of Mayors Climate Protection Agreement. Retrieved October 16, 2008 from http://www.usmayors.org/climateprotection/agreement.htm

Wheeler, Stephen. (2008, Fall). State and Municipal Climate Change Plans. Journal of the American Planning Association. Retrieved November 14, 2008 from http://da.ucdavis.edu/people/websites/wheeler/Wheeler\%20JAPA\%20Climate\%20Change\%20a rticle.pdf

World Commission on Environment and Development. (1987, March 20). Our Common Future. Retrieved November 8, 2008 from http://www.worldinbalance.net/agreements/1987-brundtland.php

\section{CITY BACKGROUND (GENERAL)}

Delgado, Sonia. (2009, May ll). Administrative Manager, City of Patterson Public Works Department. Personal Interview via Email.

Patterson (California), City of. (2002, October). Community Design Guidelines \& Downtown Physical Design Plan. Retrieved October 17, 2008 from http://www.ci.patterson.ca.us/Default.aspx?pi=75\&ni=96

Patterson (California), City of. (2008, September 5). General Plan Background Report Update Draft.

Patterson (California), City of. (2004). General Plan Policy Document.

Patterson (California), City of. (2006). Villages of Patterson Development Plan Environmental Impact Report.

Simpson, Rod R. (2008, November 4). Director, City of Patterson Community Development Department. Personal Interview.

Stapley, Garth. (2009, March 29). Patterson surpasses all, with city land swelling 250\%. The Modesto Bee. Retrieved May, 242009 from http://www.modbee.com/local/story/6464ll.html

\section{REGIONAL BACKGROUND (GENERAL)}

(2008, October 2). Stanislaus needs to take part on regional planning. The Modesto Bee. Retrieved October 28, 2008 from http://www.modbee.com/opinion/story/449608.html 
California Department of Conservation Division of Land Resource Protection

(DLRP). (2006, December). California Farmland Conversion Report 2002-2004. Retrieved

November 13, 2008 from http://redirect.conservation.ca.gov/dlrp/fmmp/pubs/2002-

2004/FCR/FCR 0204.pdf

California Partnership For The San Joaquin Valley. (2006, October). Strategic

Action Proposal. The San Joaquin Valley: California's $21^{\text {st }}$ Century Opportunity. Retrieved November 6, 2008 from http://www.sjvpartnership.org/uploaded files/Doc/TheSanJoaquinValley.pdf

Great Valley Center. (2008). Mapping the Future of the Valley: 2007-2008

Annual Report. Retrieved November 7, 2008 from http://www.greatvalley.org/publications/GVC.Annual.Report.2008.pdf

San Joaquin Valley Blueprint. http://valleyblueprint.org/

Stanislaus (California), County of. (1994). General Plan. Retrieved October 16, 2008.

Stanislaus (California), County of. (2002, January). Visioning Project 2000.

Stanislaus (California), County of. (2009). http://www.stancounty.com

\section{Case Studies (Best Practices ReView)}

Benicia (California), City of. (1999). General Plan Element: Community Development and Sustainability.

Berkeley (California), City of. (2008, September). Climate Action Plan (2 ${ }^{\text {nd }}$ Draft for Public Review). Retrieved from http://www.berkeleyclimateaction.org/Content/10054/Climate Action Plan.html

Boulder (Colorado), County of. (2007, May). Comprehensive Plan Sustainability Element.

Burbank (California), City of. (2008, January). Sustainability Action Plan.

Cal Poly. (2009, May). Benicia Climate Action Plan.

Fresno (California), City of. 23 (April 2007). Fresno green: The City of Fresno's Strategy for Achieving Sustainability. Retrieved September 17, 2008 from http://www.fresno.gov/NR/rdonlyres/4316C47B-49C5-417A-899C2A6C7EB4DAD3/0/GreenStrategy.pdf

Grand Terrace (California), City of. (2008, January). Sustainable Development Element (Draft).

Los Angeles (California), City of. (2007, May). Green LA - An Action Plan to Lead the Nation In Fighting Global Warming.

Marin (California), County of. Community Development Agency. (2007, November 6). Marin Countywide Plan. 
Pasadena (California), City of. (2006). Green City Action Plan. Retrieved October

17, 2008 from http://www.ci.pasadena.ca.us/permitcenter/greencity/GreenActionplanWeb.pdf

Pasadena (California), City of. (2007). Green City Report. Retrieved October 17,2008 from http://www.ci.pasadena.ca.us/permitcenter/greencity/Documents/GreenCityReport.pdf

Sacramento (California), City of. (2007, December). Creating A Sustainable City: A Master Plan to Move the City of Sacramento Towards Sustainability.

Sacramento (California), City of. (2008, February). Creating A Sustainable City: Implementation Plan.

SANDAG. (2007, October 11). Background Report on Climate Action Plans. Retrieved September 17, 2008 from http://www.sandag.org/uploads/projectid/projectid 332 8469.pdf

San Diego (California), City of. (2008, March). General Plan Conservation Element. Retrieved September 17, 2008 from http://www.sandiego.gov/planning/genplan/pdf/generalplan/adoptedconserelemfv.pdf

San Francisco (California), City of. (2008). Building A Bright Future: San Francisco's Environmental Plan. Retrieved September 17, 2008 from http://www.cisco.com/web/about/ac79/docs/wp/cud/San Francisco Collateral CUD Final.pdf

San Francisco (California), City of. (2004, September). Climate Action Plan.

Santa Monica (California), City of. (2006, October 24). The Sustainable City Plan. http://www.smgov.net/epd/scp/pdf/SCP 2006 Adopted Plan.pdf

Santa Monica (California), City of. (2008, August 8). Sustainable City Progress Report. http://www.smgov.net/epd/scpr/index.htm

Santa Monica (California), City of. (2007, September 20). The Sustainable City Report Card. http://www.smgov.net/epd/scpr/SCRC ReportCard 2007.pdf

Santa Monica (California), City of. (1994, September). Summary of Sustainable Procurement Policies. http://www.smgov.net/epd/SP/pdf/Sustainable Procurement policies.pdf

Seattle (Washington), City of. (2005, January). Comprehensive Plan: Toward a Sustainable Seattle. Retrieved September 17, 2008 from http://www.seattle.gov/dpd/Planning/Seattle s Comprehensive Plan/ComprehensivePlan/defaul t.asp

Seattle (Washington), City of. (2006, September). Seattle, a Climate Change: Meeting the Kyoto Challenge: Climate Action Plan. Retrieved September 17, 2008 from http://www.seattle.gov/climate/docs/SeaCAP plan.pdf 


\section{AdDitionAl RefERENCEs By SUBtOPIC}

\section{LAND USE \& TRANSPORTATION}

Healthy Air Living. (2008). Commute Green in the San Joaquin. Retrieved November 8, 2008 from http://www.healthyairliving.com/CommuteGreenFrame.htm

League of American Bicyclists. (2009). Bicycle Friendly Community. Retrieved May 28, 2009 from http://www.bikeleague.org/programs/bicyclefriendlyamerica/communities/

New York (New York), City of. (2008). Sustainable Streets: Strategic Plan for the New York City Department of Transportation 2008 and Beyond. Retrieved November 25, 2008 from http://www.nyc.gov/html/dot/downloads/pdf/stratplan compplan.pdf

Patterson (California), City of. (2001, July 3). Bicycle Transportation Master Plan: Amendment to the Transportation Element of the General Plan.

Stanislaus Council of Governments. (2008, September). Stanislaus County Non-Motorized Transportation Plan. Retrieved November 13, 2008 from http://www.stancog.org/pdf/documents/bicycle/non-motorized-plan.pdf

Stanislaus Council of Governments. (2007). Regional Transportation Plan.

Stanislaus Economic Development and Workforce Alliance. (2004, March). Patterson Commuter Survey.

Stanislaus Regional Transit (StaRT). (2009). http://www.srt.org

ENERGY

Alliance to Save Energy. (2009). Energy Fact Sheet. Retrieved May 24, 2009 from http://energyhog.org/adult/pdf/EnergyFacts.pdf

Build It Green. (2009). GreenPoint Rated. http://www.builditgreen.org

California Climate Action Network. (2009). Green Building. Retrieved May 19, 2009 from http://www.cacities.org/resource files/26927.Green Building.pdf

California Energy Commission. (2006). Cool Roofs. Retrieved June 6, 2009 from http://www.consumerenergycenter.org/coolroof/

Collaborative Economics. (2003, March). Renewable Energy: Strategic Opportunities for the Great Central Valley. Retrieved November 7, 2008 from http://www.greatvalley.org/pub documents/2004 621165434 energy report.pdf

Covanta Energy. (2009). Covanta Stanislaus. Retrieved May 19, 2009 from http://www.covantaholding.com/site/stanislaus/covanta-stanislaus.html

Flex Your Power. (2009). California Energy Efficiency and Conservation. http://www.fypower.org 
Great Valley Center. Energy Program: Energy Independence For The Great Central Valley. Retrieved November 7, 2008 from http://www.gvc-energy.org/

Great Valley Center. (2009, May 5). The Great Valley Center Energy Primer. Retrieved May 28, 2009 from http://www.greatvalley.org/artman2/publish/othergvcpub/pub Great Valley Energy Primer.asp $\underline{x}$

Great Valley Center. (Date Unknown). Great Valley Solar Partnership. Retrieved November 7, 2008 from http://www.greatvalley.org/pub documents/2004 621165434 energy report.pdf

Kornell, Sam. (2009, April 3). Is White the New Green? Three California energy experts make a convincing - and sincere - case that painting roofs white in the hot parts of the planet could offset the greenhouse gas woes caused by the world's cars. Miller-McCune. http://www.miller-mccune.com/science environment/is-white-the-new-green-11l7

Marin (California), County of. (2008, June). Single Family Dwelling Energy Efficiency Ordinance (SFDEEO). Retrieved from http://www.co.marin.ca.us/depts/CD/main/comdev/advance/sustainability/greenbuilding/pdf/Or d3492-2008SFDEEO.pdf

Marshall, Lynn. (2007, November). California Energy Demand 2008 - 2018: Staff Revised Forecast - Final Staff Report, 2nd Edition. Retrieved May 19, 2009 from http://www.energy.ca.gov/publications/displayOneReport.php?pubNum=CEC-200-2007-015$\underline{\mathrm{SF} 2}$

Simons, George and McCabe, Joe. (2005, April). California Solar Resources In Support of the 2005 Integrated Energy Policy Report. Research and Development, Energy Research and Development Division, California Energy Commission. Retrieved May 19, 2009 from http://www.energy.ca.gov/2005publications/CEC-500-2005-072/CEC-500-2005-072-D.PDF

Stanislaus Resource Recovery Facility (SRRF). (2009). A Waste-to-Energy Facility. Retrieved May 28, 2009 from http://www.stanislauswte.com/

The Energy Foundation. (2002). Renewable Energy Atlas of the West. Retrieved November 6, 2008 from http://www.energyatlas.org/contents/default.asp

The Weather Channel. (2009). The truth about CFL light bulbs. Retrieved May 28, 2009 from http://climate.weather.com/articles/dccflbulbs2009.html

Turlock Irrigation District (TID) Water \& Power. (2009). http://www.tid.org

U.S. Department of Energy. (2008). Building Technologies Program. Energy Efficiency and Renewable Energy. Retrieved November 7, 2008 from http://wwwl.eere.energy.gov/buildings/

U.S. Green Building Council. (2009). http://www.usgbc.org/ 


\section{WASTE REDUCTION \& RECYCLING}

Patterson (California), City of. (1999). Recycling. Retrieved May 24, 2009 from http://www.ci.patterson.ca.us/Default.aspx?pi=138\&eni=158

Palo Alto (California), City of. (2008, March). Analysis of the Issues Regarding Single-Use Retail Carryout Bags.

Stanislaus Resource Recovery Facility (SRRF): A Waste-To-Energy Facility. (2008). Retrieved November 7, 2008 from http://www.stanislauswte.com/index.html

\section{WATER}

California Department of Water Resources. (2009). Drought Water Bank. Retrieved May 24, 2009 from http://www.water.ca.gov/drought/bank/

California Urban Water Conservation Council. (2009). Group 1: Water Suppliers. Retrieved May 24, 2009 from http://www.cuwcc.com/about/default.aspx

Patterson (California), City of. (2008, July). Non-Potable Water Master Plan \& Feasibility Study.

Patterson (California), City of. (2006, December). Urban Water Management Plan.

Patterson (California), City of. Water Conservation. Retrieved November 7, 2008 from http://www.ci.patterson.ca.us/Default.aspx?pi=139\&eni=159

Patterson (California), City of. Water Operations. Retrieved November 7, 2008 from http://www.ci.patterson.ca.us/Default.aspx?pi=84\&ni=150

Patterson (California), City of. Stormwater Program. Retrieved November 7 , 2008 from http://www.ci.patterson.ca.us/Default.aspx?pi=89\&ni=110

\section{PuBLic HEALTH}

Akbari, Hashem. (2000, August 30). Heat Island Group. Retrieved June 6, 2009 from http://eetd.lbl.gov/heatisland/

American Lung Association. (2009). Health Risks: Particle Pollution. Retrieved May 24, 2009 from http://www.stateoftheair.org/2009/health-risks/health-risks-particle.html

American Lung Association. (2009). State of the Air: Stanislaus County. Retrieved May 24, 2009 from http://www.stateoftheair.org/2009/states/california/stanislaus06099.html

Marin (California), County of. (2008, July 1). Woodsmoke Ordinance. Retrieved May 24, 2009 from http://www.co.marin.ca.us/depts/CD/main/comdev/advance/sustainability/greenbuilding/pdf/W oodsmokeOrd3395.pdf 
San Joaquin Valley Air Pollution Control District. (2008, October). Annual Report to the Community. Retrieved October 28, 2008 from http://www.valleyair.org/General info/pubdocs/2008AnnualReportfinal-web.pdf

San Joaquin Valley Air Pollution Control District. (2009). Ambient Air Quality Standards \& Valley Attainment Status. Retrieved May 24, 2009 from http://valleyair.org/aqinfo/attainment.htm

U.S. Environmental Protection Agency. (2009). Six Common Air Pollutants. Retrieved May 24, 2009 from http://www.epa.gov/air/urbanair/

\section{SustainABle ECONOMIC DEVELOPMENT}

Great Valley Center. (2005, January). Assessing the Region Via Indicators: The Economy 1999-2004. The State of the Great Central Valley of California. Retrieved November 7, 2008 from http://www.greatvalley.org/pub documents/2005 1 18135943 indicator econ05 report.pdf

Patterson-Westley Chamber of Commerce. (8 May 2008). Retrieved October 16, 2008 from http://www.patterson-westleychamber.com/

Santa Monica (California), City of. (2008). Green Business Certification Program. http://www.smgbc.org/

Santa Monica (California), City of. (2008). Business Greening Program. http://www.sustainableworks.org/

\section{OUTREACH \& AWARENESS}

California Environmental Protection Agency. (2009). Education and the Environment Initiative (EEI). Retrieved May 24, 2009 from http://www.calepa.ca.gov/education/eei/

Delta Sierra CREEC (California Regional Environmental Education Community) Environmental Education Network. (2009, May 28). http://www.creec.org/region6/

National Environmental Education Foundation. (2009). National Environmental Education Week. Retrieved May 24, 2009 from http://www.eeweek.org/

No Child Left Inside Coalition. (2009). Environmental Education and the No Child Left Behind Act. Retrieved May 24, 2009 from http://www.eenclb.org

\section{FUNDING}

California Alternative Energy and Advanced Transportation Financing Authority (CAEATFA). Retrieved June 3, 2009 from http://www.treasurer.ca.gov/caeatfa/ 
California Air Resources Board. (2009, May 28). Air Pollution Incentives, Grants and Credit Programs. Retrieved June 3, 2009 from http://www.arb.ca.gov/ba/fininfo.htm

California Department of Transportation. (2009). Transportation Development Act. Retrieved June 3, 2009 from http://www.dot.ca.gov/hq/MassTrans/State-TDA.html

California Department of Water Resources (2009). Funding. Retrieved June 3, 2009 from http://www.water.ca.gov/nav/nav.cfm?loc=t\&id=103

California Economic Recovery Portal. (2009). Information Related to the American Recovery and Reinvestment Act. Retrieved June 3, 2009 from http://www.recovery.ca.gov/

California Energy Commission. (2009). Bright Schools Program. Retrieved June 3, 2009 from http://www.energy.ca.gov/efficiency/brightschools/

California Energy Commission. (2009). Energy Efficiency Financing. Retrieved June 3, 2009 from http://www.energy.ca.gov/efficiency/financing/

California Energy Commission. (2009). Energy Partnership Program. Retrieved June 3, 2009 from http://www.energy.ca.gov/efficiency/partnership/

California Public Utilities Commission. (2009). Self-Generation Incentive Program. Retrieved June 3, 2009 from http://www.cpuc.ca.gov/PUC/energy/DistGen/sgip/

California Solar Initiative (CSI). (2009). Retrieved June 3, 2009 from http://www.cpuc.ca.gov/PUC/energy/solar http://www.gosolarcalifornia.ca.gov/csi/index.html

California State Integrated Waste Management Board (2009). Grants and Loans. Retrieved June 3, 2009 from http://www.ciwmb.ca.gov/Grants/

California State Water Resources Control Board (2009). Grants and Loans. Retrieved June 3, 2009 from http://www.swrcb.ca.gov/water issues/programs/grants loans/

California State Water Resources Control Board (2009). Financial Assistance Programs - Grants and Loans. Retrieved June 3, 2009 from http://www.swrcb.ca.gov/water issues/programs/grants loans/irwmgp/index.shtml

California State Water Resources Control Board (2009). Water Recycling Funding Program (WRFP). Retrieved June 3, 2009 from http://www.swrcb.ca.gov/water issues/programs/grants loans/water recycling/index.shtml

Caltrans Division of Local Assistance. (2009). Bicycle Transportation Account (BTA). Retrieved June 3, 2009 from http://www.dot.ca.gov/hq/LocalPrograms/bta/btawebPage.htm

Cool California. (2009). Find Resources. Retrieved June 3, 2009 from http://www.coolcalifornia.org/article/find-resources 
Federal Highway Administration. (2009). Congestion Mitigation and Air Quality (CMA2) Improvement Program. Retrieved June 3, 2009 from http://www.fhwa.dot.gov/environment/cmaqpgs/

Federal Transit Administration. (2009). Grants \& Financing. Retrieved June 3, 2009 from http://www.fta.dot.gov/grants financing.html

Great Valley Center. (2009). Renewable Energy: Solar Incentives. Retrieved June 3, 2009 from http://www.greatvalley.org/energy/solarincent.aspx

ICLEI - Local Governments for Sustainability. (2009). Economic Recovery Funding Updates. Retrieved March 31, 2009 from http://www.icleiusa.org/action-center/financingstaffing/stimulus-funding-updates

ICLEI - Local Governments for Sustainability. (2009). Overview of StimulusFunded Programs and Initiatives. Retrieved June 3, 2009 from http://www.icleiusa.org/actioncenter/financing-staffing/overview-of-stimulus-funded-programs-and-initiatives

ICLEI - Local Governments for Sustainability. (2009). Stimulus-Funded Programs and Opportunities. Retrieved June 3, 2009 from http://www.icleiusa.org/actioncenter/financing-staffing/additional-stimulus-funded-opportunities

Local Government Commission. (2009). Funding Opportunities. Retrieved March 31, 2009 from http://www.lgc.org/freepub/energy/funding.html

PMC. (2009, March 26). Funding Opportunities. Retrieved March 31, 2009 from http://carbonconscious.us/funding.html

San Joaquin Valley Air Pollution Control District. (2009). Grants and Incentive Programs. Retrieved June 3, 2009 from http://www.valleyair.org/Grant Programs/GrantPrograms.htm

San Joaquin Valley Clean Energy Organization. (2009). Finding Funding. Retrieved June 3, 2009 from http://www.sjvcleanenergy.org/finding-funding

Turlock Irrigation District (TID) Water \& Power. (2009). Residential Rebates. Retrieved June 3, 2009 from http://www.tid.org/Residential/Rebates/index.htm

U.S. Department of Energy. (2009). Database of State Incentives for Renewables \& Efficiency. Retrieved June 3, 2009 from http://www.dsireusa.org

U.S. Department of Energy. (2009). Energy Efficiency and Conservation Block Grants. Retrieved June 3, 2009 from http://www.eecbg.energy.gov/

U.S. Department of Energy. (2009). Federal Incentives/Policies for Renewables e Efficiency. Retrieved June 3, 2009 from http://www.dsireusa.org/incentives/index.cfm?state=us\&re=1\&EE=1 
U.S. Department of Energy. (2009). Financial Opportunities. Retrieved June 3, 2009 from http://wwwl.eere.energy.gov/cleancities/financial opps.html

U.S. Environmental Protection Agency. (2009). Clean Water State Revolving Fund. Retrieved June 3, 2009 from http:/www.epa.gov/owm/cwfinance/cwsrf/

U.S. Environmental Protection Agency. (2009, May 26). Energy Star: Federal Tax Credits for Energy Efficiency. Retrieved June 3, 2009 from http://www.energystar.gov/index.cfm?c=products.pr tax credits

U.S. Environmental Protection Agency. (2009). Environmental Education Grants. Retrieved June 3, 2009 from http://www.epa.gov/Education/grants.html

DID YOU KNOW? FACTS AND STATISTICS

http://climate.weather.com/articles/dccflbulbs2009.html

http://climate.weather.com/articles/dctraveltips2009.html

http://www.cacities.org/resource files/26927.Green Building.pdf

http://www.chrisjordan.com

http://www.epa.gov/climatechange/wycd/stateandlocalgov/local.html

http://www.fypower.org/res/upgrade/

http://www.ourgreensol.org/

http://www.saveourh20.org/index.cfm/why-conserve/how-much-water-do-i-use/

http://www.wateraware.org/tips household.asp

\section{INTERNET IMAGES}

http://www.leoncountyfl.gov/recycling/images/GlobeguyComposting.jpg

http://www.rmc.sierraclub.org/rfg/Images/ist2 581051 green recycle symbol.jpg

http://www.blogcdn.com/www.engadget.com/media/2008/07/solar-prius.jpg

http://www.chrisjordan.com/images/current2/1171402753.jpg

http://www.chrisjordan.com/images/current2/1178475329.jpg

http://recycleraccoon.files.wordpress.com/2009/03/landfill.jpg

http://www.sierraclubgreenhome.com/cms/wp-content/uploads/solar.jpg

http://i.treehugger.com/osakasolar.jpg 
http://solar.envirohub.net/images/solar-power.jpg

http://www.jewishjournal.com/images/bloggers auto/solar-panels.jpg

http://www.sdenergysmart.com/IMAGES/img-cfl5.jpg

http://www.wicknet.org/clubs/bear/images/CFL sky.jpg

http://creativegreenius.files.wordpress.com/2009/01/car-exhaust-fumes.jpg

http://blog.silive.com/weather/2009/01/CarExhaust.jpg

http://www.pattersonirrigator.com

http://www.carolstream.org/Services/Engineering/images/Water\%20Sense\%20Promotional\%20Label.jp g

http://weblogs.newsday.com/news/local/longisland/politics/blog/water.jpg

http://www.nacdnet.org/stewardship/2008/downloads/images/water\%20drop.jpg

http://people.ucsc.edu/-bkdaniel/number-water-footprint.jpg

http://pro.corbis.com/images/42-15342580.jpg?size =572\&uid=\{9FBE5281-79F6-43EE-BB032F62AB5C597E\}

http://village.croton-on-hudson.ny.us/Public Documents/CrotonHudsonNY BComm/00B2078E000F8513.0/BCP.jpg

http://www.orion.lib.mi.us/township/police/images/pedestrianX.jpg

http://www.cycleguelph.ca/wp-content/uploads/2008/10/flickr-bike-signal-john-swann-davis.jpg

http://www.cityofvancouver.us/upload/images/Transportation/CurbExtBulbOut2.jpg 


\section{SUSTAIN B BI LIT}
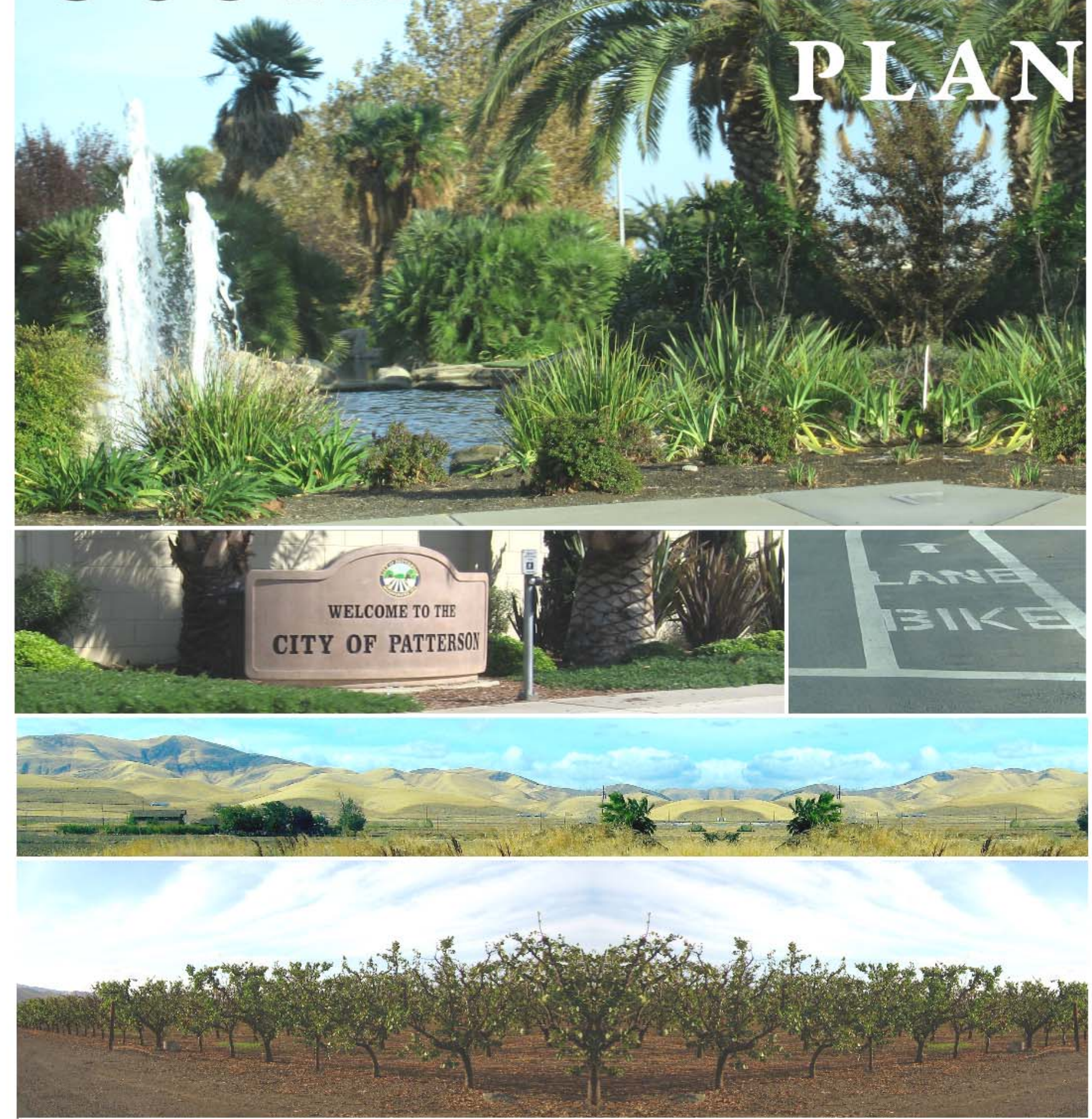


\title{
PATTERSON SUSTAINABILITY PLAN
}

\author{
June 2009
}

Prepared for

The City of Patterson, California

Apricot Capital of the World

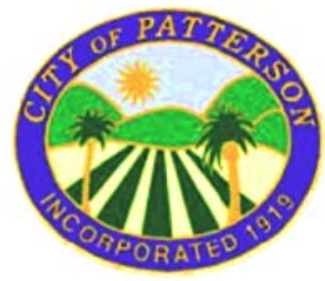

by

Colin B. Clarke

Crawford

Multari \&

Clark

ASSOCIATES 
EXECUTIVE SUMMARY.

i

\section{INTRODUCTION}

City Profile

Purpose of the Sustainability Plan 1

Climate Change and Sustainability ........................................................................ 2

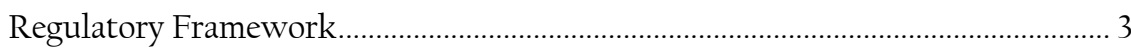

How the Plan Was Prepared..................................................................................

Patterson's Principles of Sustainability ………………………………………... 5

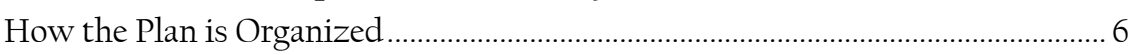

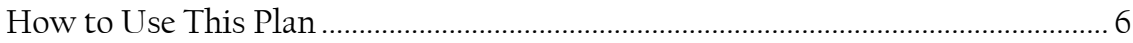

Relationship to Other Policy Documents .............................................................. 7

\section{SUSTAINABILITY FOCUS AREAS}

LAND USE \& TRANSPORTATION ............................................... 8

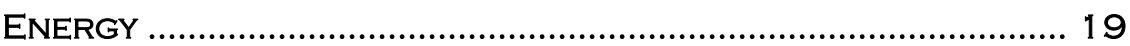

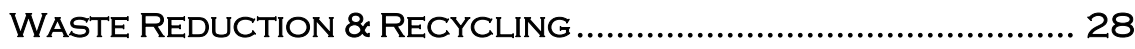

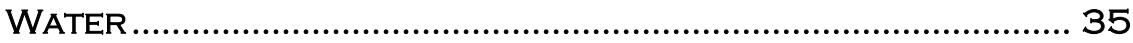

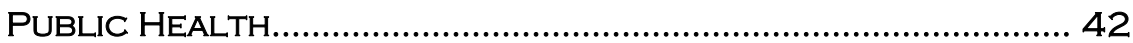

SUSTAINABLE ECONOMIC DEVELOPMENT .................................... 49

OUTREACH \& AWARENESS ...................................................... 54

PHASING, IMPLEMENTATION \& FUNDING ..........................6 1

\section{APPENDIX}

BEST PRACTICES REVIEW A-1

NEEDS ASSESSMENT \& POLICY ..................................................

ADDITIONAL ACTIONS FOR CONSIDERATION ................................. C-1

GLOSSARY

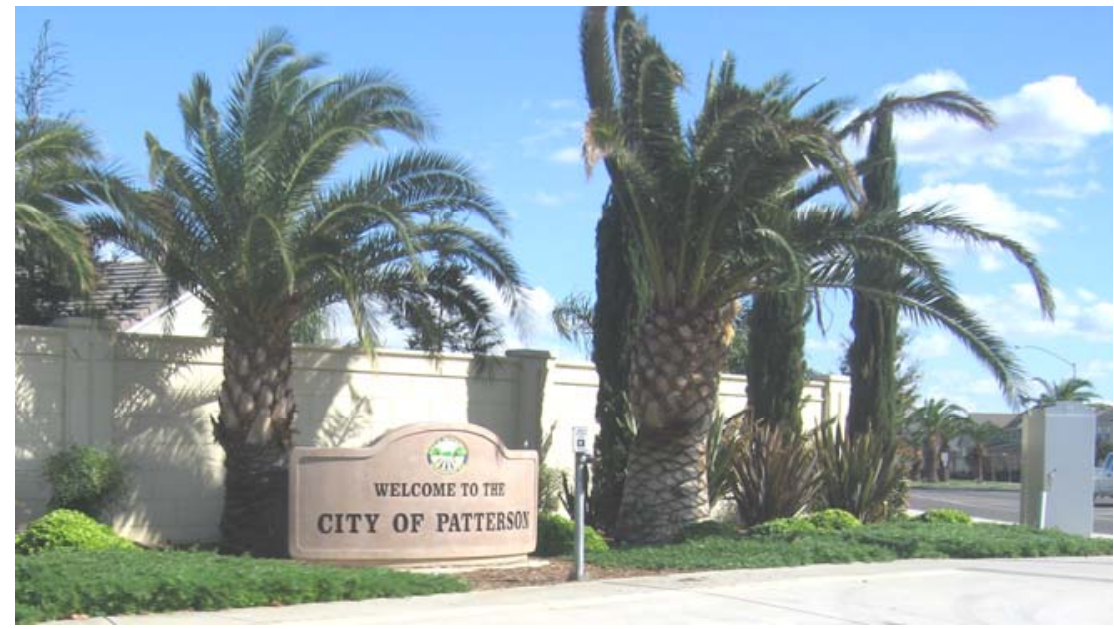





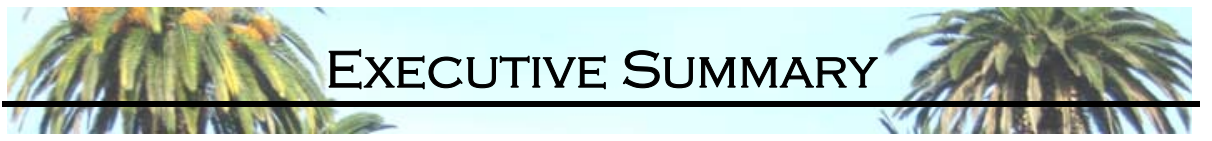

The General Plan is currently undergoing a comprehensive update, making this an ideal opportunity to incorporate principles of sustainability, both to comply with state and federal law, and to lead by example so that residents and private businesses follow.

Although the City of Patterson Sustainability Plan (PSP) will inform decision-making by way of its Goals, as in a General Plan, it identifies Actions needed to implement measures to achieve sustainability. Following the Annual Progress Report, the City will revise the plan regularly as priorities change due to knowledge of new best practices and performance indicators brought on by improved technology, availability of funding, or other factors. Within the Near-Term (five years), the City will also conduct a Greenhouse Gas Emissions Inventory, establish a reduction target, and develop and adopt a Climate Action Plan as a separate document.

The Goals and Actions to improve sustainability are organized into six focus areas and an overall outreach chapter:

1. Land Use \& $\mathbb{E}$ Transportation

2. Energy

3. Waste Reduction \& Recycling

4. Water

5. Sustainable Economic Development

6. Public Health

7. Outreach \& Awareness

Following the Sustainability Focus Areas is a section on Phasing, Implementation \& Funding, discussing potential funding sources and the proposed Near-Term Phasing to occur within the first five years following plan adoption. The Appendix consists of the Best Practices Review, Needs Assessment \& Policy Audit, Additional Actions for Consideration, and Glossary.

\section{BEST PRACTICES REVIEW}

Planning for sustainability and climate change is a relatively new practice in local and regional agencies. The Best Practices Review provides a summary of planning practices that support sustainability, derived from Sustainability Plans, Climate Action Plans, and General Plan Elements from multiple jurisdictions that incorporate principles of sustainability. "Best practices" are goals, objectives, policies, and programs that provide effective strategies for water conservation, energy efficiency, compact urban growth, a jobs/housing balance, waste reduction and recycling, improved air quality, and outreach \& education. These were analyzed to determine which ideas, approaches, and techniques can be applied in Patterson, given careful consideration of the City's characteristics including current land use, urban form, and geographical context (found in the Needs Assessment). After a thorough review, some of these model policies were adapted to work in 
Patterson, while new policies were crafted to address specific issues unique to Patterson.

\section{Needs Assessment \& Policy Audit}

The Needs Assessment \& Policy Audit (Appendix B) provides an evaluation of existing conditions in Patterson, organized by "Community Strengths Promoting Sustainability" and "Challenges To Improving Sustainability." The City of Patterson has many strengths, such as its relatively small size, making alternative transportation more viable. The City's considerable amount of vacant and underutilized land within City limits makes continued compact urban growth a realistic goal, minimizing outward expansion and preserving agricultural land. The tree-lined main thoroughfares help improve air quality, surrounding agriculture allows for local food purchasing, and the abundance of parks provides a place for recreation and physical fitness. The City also has a curbside garbage, green waste, and recycling program, and an ordinance that requires drought-tolerant landscaping to conserve water. In terms of challenges, the City is surrounded by Prime Agricultural soils with property owners choosing Non-Renewal of their Land Conservation contracts under the Williamson Act, leaving them increasingly susceptible to urban development.

The Policy Audit contains an inventory and analysis of existing General Plan goals, objectives, policies, and programs supporting sustainability (organized by General Plan Element). Many of Patterson's General Plan policies already address practices of water conservation, energy efficiency, and compact growth, for example, but the Sustainability Plan proposes specific Actions to reduce long-distance commuting to work, improve the jobs/housing ratio, conserve water, reduce energy use, and preserve agricultural land. 


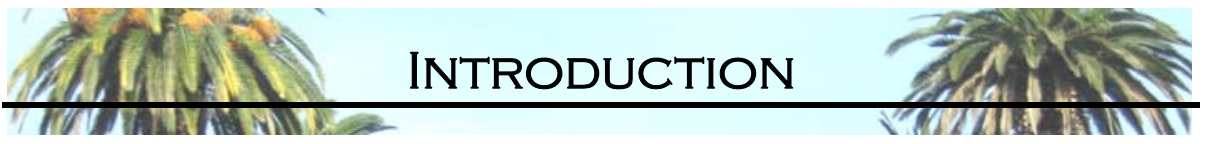

Our built environment, transportation systems, economy, and society are primarily unsustainable, but there are simple actions the City and its constituents can take to make a difference. Sustainability is defined as "meeting the needs of the present generation without compromising the ability of future generations to meet their needs" (Brundtland Commission 1987). A sustainable community is one where natural resources are used only at a rate that can be replenished by nature (i.e. renewable resources), with indicators such as local agriculture, energy efficiency, a reliable water supply, less waste, more reuse and recycling, a healthy urban forest, and a system of parks, open space, and pathways. Sustainable development balances economic prosperity, environmental protection, and social equity.

Local jurisdictions are charged with implementation of adaptation and mitigation measures to slow climate change, prevent environmental disasters, and help ensure sustainability. The City has the opportunity to lead by example - creating new jobs, improving public health, ensuring a more sustainable environment - all while strengthening the economy. However, achieving sustainability will require changes in personal behavior. It will require "a new consciousness" and a commitment to do things differently than we have in the past (Sacramento Sustainability Master Plan p.6). The City of Seattle describes it as "the defining challenge of our time" (Climate Action Plan 2006).

\section{City PROFILE}

Patterson is a community of about 21,000 people (an $83 \%$ increase, or nearly double the 11,600 residents counted in the 2000 Census) located approximately 20 miles southwest of Modesto (the County seat), in the western part of Stanislaus County, in the San Joaquin Valley. The nearest community is Westley, six miles northwest of Patterson. The selfproclaimed "Apricot Capital of the World" is adjacent to Interstate-5 and three miles west of the San Joaquin River. Highway-33 runs northwestsoutheast along $2^{\text {nd }}$ Street, separating the downtown core from industrial uses to the east. Incorporated in 1919, Patterson is a small, rural town of about three square miles, surrounded by agricultural land, and a history of apricots, almonds, walnuts, dry beans, tomatoes, broccoli, spinach, peas, and melons. The City derives much of its economic vitality from agriculture and food processing, but it also has a large and expanding business park. Patterson's street layout, inspired by the metropolitan areas of Paris, France and Washington, D.C., features a circular format in the central district surrounded by radiating streets. The City is also known for its tree-lined main thoroughfares (eucalyptus, sycamore, and palm trees). In recognition of its agricultural heritage, the City is home to the annual Apricot Fiesta in June.

\section{Purpose of The Sustainability Plan}

The Patterson Sustainability Plan sets forth specific actions to improve the City's overall sustainability now and in the future. It recommends specific 
The world will not evolve past its current state of crisis by using the same thinking that created the situation. - Albert Einstein changes to the City's current operational and decision-making practices, as well as changes the private sector can make (voluntary or otherwise). The objective of the Plan is to preserve the unique character and quality of life in Patterson, minimize adverse environmental impacts, and promote efficient use of land, materials, energy, water, and other finite resources. This Plan provides measurable targets (Progress Indicators) to regularly assess the effectiveness of these efforts, and also responds to recent state and federal legislation aimed at reducing the effects of local decision-making on climate change. The following Focus Areas are addressed: Land Use \& Transportation, Waste Reduction \& Recycling, Energy, Water, Public Health, Sustainable Economic Development, and Outreach \& Awareness.

Innovative policies and programs are needed to demonstrate leadership and to educate residents and businesses about sustainability and climate change. There are many benefits the City can derive from the Actions proposed in this Plan. By preserving agricultural land and promoting decentralized food purchasing, local farming will remain a feasible livelihood, strengthen the regional economy, improve public health, and encourage compact growth. It is important for Patterson to preserve its agricultural heritage and retain the City's identity as the Apricot Capital of the World. By attracting more jobs to Patterson and encouraging a more dense urban form as an alternative to sprawl, the City can reduce the need for a long commute to work and increase the viability of using alternative modes of transportation such as walking, bicycling, and transit. This will help reduce the use of fossil fuels and the country's dependence on foreign oil, benefiting national security and the United States economy rather than those overseas, while achieving substantial reductions in greenhouse gas emissions, resulting in cleaner air. Measures for energy efficiency, waste reduction, and water conservation reduce the need for costly new infrastructure, protect natural resources, help ensure a reliable water supply, and result in cost-savings for residents, businesses, and the City. Ultimately, these Actions can fulfill the City's responsibility to maintain a higher quality of life for current and future residents.

\section{CLIMATE CHANGE AND SUSTAINABILITY}

Sustainability is an extremely broad concept, with several aspects to which it subscribes, from compact growth to energy efficiency and a "green" economy, to human and community health, and the conservation of natural resources. These topics under sustainability are interrelated. Greenhouse gas (GHG) emissions, a newly-recognized air pollutant, is another aspect under the realm of sustainability. Climate change mitigation requires the reduction of GHG emissions and adaptation to forthcoming changes. Both mitigation and adaptation to climate change influence the elements of sustainability.

Global warming is characterized by rising temperatures due to the greenhouse effect, which is known to be primarily caused by greenhouse gas emissions from vehicles, buildings, power plants, and other man-made sources - rather than natural variations in climate (PEW Center on Global Climate Change 2009). The impact of global warming is known as climate change, increasingly viewed with consensus by the majority of leading scientists as a serious issue requiring immediate attention from those who 
shape policy. A holistic approach to improving sustainability can slow the rate at which climate change intensifies.

Climate change is a global problem with local consequences for sustainability. Rising temperatures and longer, more frequent heat waves can contribute to increased air pollution (smog) and a variety of public health issues, increasing asthma and respiratory illnesses due to higher ozone levels (in an Air District already known to have some of the worst air quality in the nation). The number of heat wave days per year may increase two-fold (or more), with more days of poor air quality and high ground-level ozone concentrations, meaning more stress on electricity and water supplies, an increase in heat-related deaths, and greater strain on those with respiratory and cardiovascular diseases. On average, summers will likely be hotter and drier, with wildfires, droughts, and severe storms increasing in frequency and intensity. Stanislaus County averages only 12 inches of rainfall each year. Climate change may result in changing rainfall patterns, overwhelming waterways in periods of flooding and making severe droughts far more frequent and long-lasting. The agricultural industry also may be disrupted by shifts in temperature and precipitation patterns, impacting the sustainability of the local economy. Given that the effects of climate change will adversely impact Patterson, it is in the City's best interest to promote principles of sustainability.

\section{REGULATORY FRAMEWORK}

As discussed above, this Plan responds to recent changes to State law aimed at minimizing the effects of local decision-making on climate change, thus helping to promote sustainability:

\section{SENATE BILL 1771}

Senate Bill 1771 (Sher, 2000) established the California Climate Action Registry to serve as a certifying agency for companies and local governments to quantify and register their greenhouse gas emissions for possible future cap-and-trade systems, where air pollution is controlled by providing economic incentives for achieving emissions reductions.

\section{SENATE BILL 1078}

Senate Bill 1078 (Sher, 2002) set a Renewable Portfolio Standard (RPS) requiring electricity providers to increase purchases of renewable energy resources by $1 \%$ per year until attaining a portfolio of $20 \%$ renewable resources.

\section{GOVERNOR'S EXECUTIVE ORDER S-3-05}

Executive Order S-3-05 sets a target of an 80 percent reduction of carbon emissions below 1990 levels by 2050 .

\section{ASSEMBLY BILL 32}

Assembly Bill 32 (Nunez, 2006), known as the Global Warming Solutions Act, is the nation's first comprehensive legislation to fight global warming. The Scoping Plan, which will guide the state in achieving its greenhouse gas reduction goal, was adopted on January 27, 2009. This multi-sector, market- 
based plan will encourage investment, create jobs, promote clean-energy, and make California a model for the nation. The law (AB 32) is used as justification for greenhouse gas emissions now being considered potentially significant under the California Environmental Quality Act (CEQA) given the precedents from San Bernardino County and the City of Stockton. One way to ensure the General Plan Environmental Impact Report is in compliance with $\mathrm{AB} 32$, is through the adoption of a Climate Action Plan.

In April 2007, the California Attorney General filed a lawsuit contesting the adequacy of San Bernardino County's 2030 General Plan, stating that the Plan did not adequately analyze the effects of development on global warming or identify feasible mitigation measures. This case represents the first time that the state used $\mathrm{AB} 32$ to legitimize lawsuits requiring greenhouse gas emissions to be addressed under CEQA. In August 2007, a settlement was reached where the County agreed to carry out a thirtymonth public process to conduct an inventory of greenhouse gas emissions (current levels and 1990 levels) and establish a target for reduction, making it one of the first greenhouse gas reduction plans in the state.

In January 2008, after the Draft Environmental Impact Report was issued in December 2007, the Sierra Club filed a lawsuit to block Stockton's 2035 General Plan, claiming that it failed to address the level of greenhouse gas emissions that would result from build-out of the plan, which estimated an increase in population of almost 50 percent. In September 2008, the City of Stockton reached a settlement with California Attorney General, requiring the City to identify and reduce greenhouse gas emissions by encouraging infill growth in downtown, transit-oriented development, green building ordinances (e.g. energy efficiency, water conservation, environmentallyfriendly building materials), developing a rapid transit bus system, and considering measures such as less restrictive building height requirements, and reduced permit fees.

\section{SENATE BILL 97}

Senate Bill 97 requires the Governor's Office of Planning and Research (OPR) to develop CEQA guidelines for the mitigation of GHG emissions in CEQA documents. Final CEQA guidance is expected in January 2010.

\section{SENATE BILL 1368}

Senate Bill 1368 (Perata, 2006) requires the California Energy Commission (CEC) and California Public Utilities Commission (CPUC) to set a global warming emissions standard for electricity used in California. The standard will apply to electricity generated in-state as well as electricity purchased from another state.

\section{SENATE BILL 375}

Senate Bill 375 (Steinberg, 2008) is meant to act as a tool for implementing Assembly Bill 32 by placing more importance on regional land use and transportation planning, using CEQA streamlining of permit processes as an incentive to encourage residential projects that help achieve emissions reductions, and coordinating the Regional Housing Needs Allocation 
(RHNA) process with the Regional Transportation Plan (RTP). This Bill creates incentives for Metropolitan Planning Organizations (MPOs) that implement Sustainable Communities Strategies (SCS), as defined in their RTPs, to reduce greenhouse gas emissions. A Scoping Plan has not yet been adopted.

\section{How the Plan Was Prepared}

Because planning for sustainability is relatively new, the first step in the preparation of the Patterson Sustainability Plan was the Best Practices Review (Appendix A). It identifies planning practices that support sustainability, derived from Sustainability Plans, Climate Action Plans, and General Plan Elements from multiple jurisdictions that incorporate principles of sustainability. "Best practices" are goals, objectives, policies, and programs that provide effective strategies for water conservation, energy efficiency, compact urban growth, jobs/housing balance, waste reduction and recycling, carbon sequestration, improved air quality, and outreach \& awareness. Some of the approaches were able to be adapted to work in Patterson, while new ones were crafted to address specific issues unique to Patterson.

The Needs Assessment \& Policy Audit (Appendix B) was conducted to evaluate existing conditions in Patterson. The Needs Assessment discusses "Community Strengths Promoting Sustainability" and "Challenges To Improving Sustainability," while the Policy Audit includes an inventory and analysis of existing General Plan goals, objectives, policies, and programs supporting sustainability. Major areas in need of policy change were identified so the City could focus its efforts. The best practices were analyzed to determine which ideas, approaches, and techniques can be applied in Patterson, given careful consideration of the City's characteristics including current land use, urban form, and geographical context.

Following the Best Practices Review and Needs Assessment \& Policy Audit, Patterson's Principles of Sustainability were developed by the City to help guide preparation of this Sustainability Plan and will be used to guide decision-making.

\section{PATTERSON'S PRINCIPLES OF SUSTAINABILITY}

The City of Patterson will strive to:

1. Consider the long-term impacts of policy choices while being proactive in regional planning initiatives and public/private partnerships.

2. Lead by example to preserve and protect open space, farmland, natural resources, and environmentally-sensitive areas.

3. Encourage strategic growth and efficient land use through infill development, mixed-use, and higher density, compact urban form.

4. Maintain a strong, stable, and diverse economy with sustainable, responsible green businesses. Attract more jobs to Patterson to improve the jobs/housing ratio and minimize long-distance commuting to work. 
5. Reduce auto dependency and Vehicle Miles Traveled (VMT) by expanding and improving the system of pedestrian paths and bikeways with a high degree of connectivity, while promoting health and recreation.

6. Reduce energy use and promote the use of clean, renewable energy.

7. Conserve water.

8. Reduce the volume of solid waste and promote reuse, composting, and recycling.

9. Improve Patterson's quality of life, public health, and social wellbeing by addressing air quality, reducing air pollutant levels and greenhouse gas emissions, encouraging physical fitness and healthy eating, and expanding the urban forest.

10. Increase community awareness of simple ways to change behavior, reduce their impacts, and help the City become more sustainable.

\section{How the Plan Is ORganized}

The Patterson Sustainability Plan consists of six Sustainability Focus Areas and a chapter for overall Outreach \& Awareness:

1. Land Use \& Transportation

2. Energy

3. Waste Reduction \& Recycling

4. Water

5. Sustainable Economic Development

6. Public Health

7. Outreach \& Awareness

Each chapter begins with a brief introduction and lists Patterson's Opportunities \& Constraints to improving sustainability. Strengths and Opportunities are aspects of Patterson that promote sustainability, while Constraints are aspects of Patterson that may hinder progress toward sustainability. "Recommendations" are followed by Goals, Actions, Progress Indicators, and Mid-Term (within ten years) Phasing \& Implementation. A Goal is a general direction, or a vision for sustainability. Actions are statements that guide implementation to achieve Goals. Progress Indicators are performance assessment tools that measure how well the City is achieving its sustainability goals. The Phasing \& Implementation table shows Actions recommended for the Mid-Term (within ten years of plan adoption). Actions have been prioritized based on the degree that the City has the ability to influence implementation, the degree to which they promote long-term community and environmental sustainability, and the extent that residents will benefit in terms of cost-savings and improved quality of life and public health.

Following the seven main chapters of the Plan is a section on Phasing, Implementation \& $\&$ Funding, discussing potential funding sources and the proposed Near-Term Phasing to occur within the first five years following adoption of the Plan. The Appendix consists of the Best Practices Review, Needs Assessment \& Policy Audit, Additional Actions for Consideration, and Glossary. 


\section{HoW to Use THIS PLAN}

The Patterson Sustainability Plan provides a range of strategies to ensure principles of sustainability are appropriately integrated into City policies, services, daily operations, and decision-making. The Plan is also intended to encourage residents and businesses to do their part in helping to achieve a more sustainable city. It is meant to be a working strategy document that will continue to evolve. This Sustainability Plan will be reviewed on an annual basis (through the proposed Annual Progress Report). The Report will measure successful implementation, evaluate progress, and update Actions and priorities due to knowledge of new best practices and performance indicators brought on by improved technology, availability of funding, or other factors. The City will establish an interdepartmental working group (Green Team) and an external advisory group to secure funding sources and help implement the Plan.

The City should first focus primarily on City operations to lead by example. Actions that have low cost, or no cost, can be implemented immediately with existing resources. Actions for the City, its residents, and private businesses should be economically feasible to the greatest extent possible. The most cost-effective Actions will be selected for Near-Term implementation based on an analysis of the associated costs and benefits (financial, environmental, and social), with an emphasis on investing in Actions delivering multiple benefits (e.g. cost savings, improved quality of air and water).

Partnerships and local community involvement will be crucial to the success of this Plan. Achieving sustainability will require the City's leadership, and participation by residents and businesses. Large organizations government, businesses, and industry - have the unique ability to have a positive impact by requiring sustainable practices of their employees, vendors, and customers. Education programs will be instituted to show residents and businesses what they can do to achieve a more sustainable future.

\section{RELATIONSHIP TO OTHER POLICY DOCUMENTS}

Concurrent with the process of developing this Sustainability Plan, the City of Patterson is updating the General Plan. A primary goal and objective of the General Plan Update is to create a sustainable community, minimizing environmental impacts. The Goals and Actions identified in this Sustainability Plan complement, and are intended to help implement, the policies and programs of the City's General Plan. 


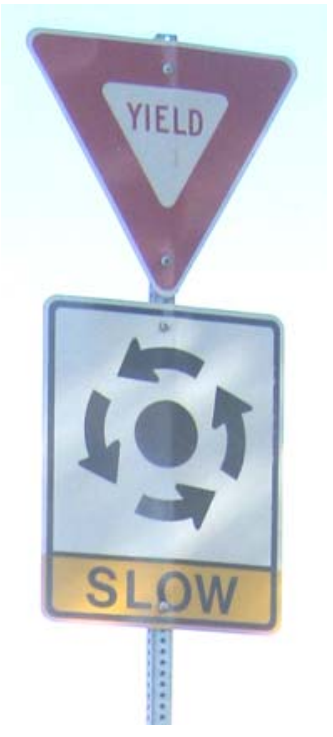

\section{LAND USE \& TRANSPORTATION}

\section{INTRODUCTION}

According to the U.S. Census (2000), the majority of Patterson's residents commute outside the City for work, making transportation and land use critical elements in improving community sustainability. In California, the transportation sector alone accounts for $40 \%$ of the state's greenhouse gas emissions (CARB). To reduce reliance on commuting, Patterson needs to improve its jobs/housing ratio. By attracting more jobs, encouraging a more efficient land use pattern that is compact, mixed-use, dense infill growth, alternative modes of transportation such as walking, biking, and public transit will become more viable options, and people will have an opportunity to reduce their dependence on private automobiles. The consequent trip reduction and decline in Vehicle Miles Traveled (VMT) reduces traffic congestion and greenhouse gas emissions, and promotes greater public health and improved air quality.

The following Opportunities and Constraints in Patterson should be addressed to improve sustainability:

\section{STRENGTHS \& OPPORTUNITIES}

1. City is relatively small in size (3 square miles), making alternative transportation more viable

2. 1,865 acres of vacant land available within City limits

3. Abundance of parks

4. Abundance of traffic circles (roundabouts)

5. Three miles of Class II facilities (on-street bicycle lanes) as of September 2008

6. All 10 Stanislaus Regional Transit (StaRT) 40-foot buses run on compressed natural gas (CNG)

\section{CONSTRAINTS}

1. Longer than average commute distance

2. Current (2009) population of 21,000 is not large enough to support frequent and convenient bus service

3. Imbalance between jobs and housing

4. Suburban sprawl (over-consumptive development pattern that encourages the use of motor vehicles)

5. Loss of agricultural land and Prime Farmland

6. Many of the Williamson Act lands surrounding the City have filed for Non-Renewal, leaving the possibility for uses other than agriculture after nine years

7. Lack of an urban-rural buffer (greenbelt)

8. Commercial areas are not within walking distance for all residents

9. Lack of connectivity (e.g. dead-end cul-de-sacs)

10. Patterson has only one mile of Class I (off-street) bicycle facilities (September 2008)

11. City Fleet Services Division has no electric or hybrid vehicles 


\section{RECOMMENDATIONS}

In order to improve sustainability, the City should re-visit its roots, promoting compact urban form, smaller homes, and an improved circulation network that emphasizes walking, bicycling, and transit for better connectivity throughout the City. This provides for a more friendly shopping environment which in turn helps the local economy, and enhances the overall quality of life. More dense, infill growth should replace conventional sprawl to preserve surrounding agricultural lands. The jobs/housing ratio should be improved to reduce the need for a long daily commute, and more efficient vehicles should replace inefficient ones for those who still choose to drive. Improving fuel efficiency reduces dependence on foreign, non-renewable energy sources and results in less greenhouse gas emissions and improved air quality. The development of such technologies also contributes to a healthier economy. Mixing land uses will provide the ability to walk

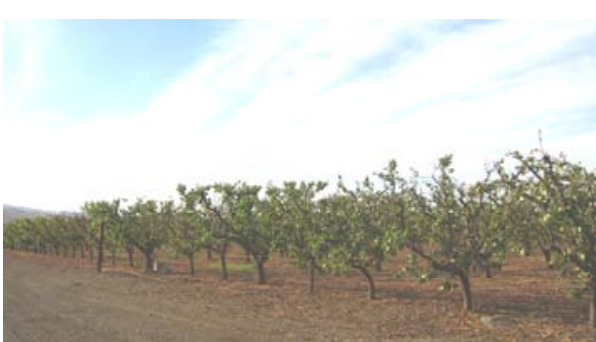
or bike to daily destinations, and narrower roads and wider sidewalks will improve the environment for pedestrians and bicyclists.

The following Goals and Actions seek to improve sustainability in Patterson:

\section{OVERALL GoALS}

1. Reduce long-distance home-to-work commuting.

2. Reduce auto dependency, i.e. number of Single Occupancy Automobile Trips, and household Vehicle Miles Traveled (VMT).

3. Improve transportation efficiency City-wide.

4. Promote and accommodate walking, biking, and public transit as alternatives to the private automobile.

\section{GOALS AND ACTIONS}

Goal LT-l: Promote more compact land use patterns to preserve Patterson's unique small town quality and facilitate the use of alternative modes of travel for the majority of daily trips.

\section{Actions}

LT-1.1 Amend Municipal Code to encourage mixed-use so that daily destinations such as banks, gyms, and food centers, as well as employment uses are located near housing and geographically dispersed. Uses such as retail, restaurants, and entertainment, however, should be centrally located to maintain a vibrant downtown.

LT-1.2 Amend Municipal Code to require all residential dwellings to be within 1/2 mile of neighborhood retail/commercial uses.
Communities can be shaped by choice... or by chance. We can keep accepting the kind of communities we get, or we can insist on getting the kind of communities we want. - Richard Moe 


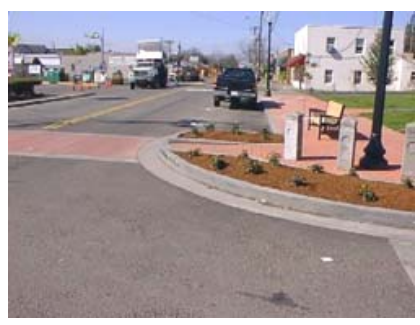

LT-1.3 Encourage and attract more goods \& services (e.g. clothing stores, food centers, one-stop-shop retail outlets) to reduce the need to drive long distances for basic necessities.

LT-1.4 Promote a variety of dwelling types to allow residents of all socioeconomic backgrounds to live within a short distance of work, school, and daily necessities.

LT-1.5 Adopt a maximum lot coverage (building footprint) or maximum floor-area-ratio (FAR) for the "Estate Residential" General Plan land use designation.

Goal LT-2: Incorporate policies that promote alternative modes of transportation into the City's development regulations.

\section{Actions}

LT-2.1 Require increased connectivity and transit-oriented development utilizing neighborhood village style development (devoid of cul-de-sacs). Ensure all residential dwellings are within $1 / 4$ mile of a transit stop.

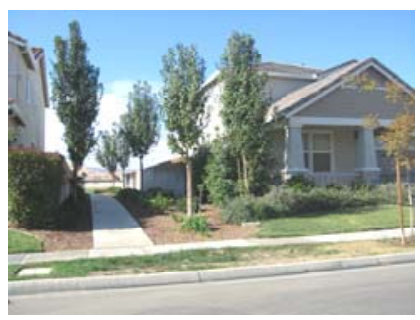

LT-2.2 Update street design standards to provide an attractive and inviting bicycle and pedestrian environment, by decreasing the required minimum pavement width of roads for each street type (local, collector, and arterial), while still maintaining adequate access for emergency vehicles.

LT-2.3 Amend Municipal Code to encourage wider sidewalks.

LT-2.4 Require Trip Reduction Plans for all major employment generators as part of the development review process, and the establishment of an Employee Alternative Commute Program (e.g. walking, bicycling, rideshare, public transit, and telecommuting).

Why higher density? Increased density is an effective way to improve energy efficiency and walkability. Multifamily and taller office buildings use far less energy per occupant than stand-alone onestory buildings. Also, public transit becomes more cost-effective and service can be more frequent because there are more more people to support it.
LT-2.5 Require new development to provide on-site amenities such as bicycle parking and employee showers.

LT-2.6 Conduct a study to determine the costs and benefits of metered parking in Downtown. More expensive parking will motivate people to take alternative transportation, or at the very least, motivate people to limit the number of trips that require paid parking.

Goal LT-3: Increase intensity of development on parcels located in the Downtown area.

\section{Actions}

LT-3.1 Offer density bonuses for mixed-use development near public transportation facilities and retail nodes. 
LT-3.2 Amend zoning regulations to allow more flexible development standards, such as decreased minimum setback requirements, density bonuses, increased maximum building height, and Floor Area Ratio (FAR), for projects that include mixed uses, green building techniques, bicycle amenities, or that include affordable housing.

LT-3.3 Explore the option of a Transfer of Development Rights (TDR) program.

Goal LT-4: Develop a Parking Master Plan to manage parking in a manner that facilitates higher intensity, compact development.

\section{Actions}

LT-4.1 Allow flexible (reduced) parking requirements for mixed-use development near public transit facilities. Consider maximum parking requirements, shared parking lots, and in-lieu parking fees in place of required off-street parking.

LT-4.2 Amend Municipal Code to encourage parking in the rear of buildings. Design residential development to be neighborhood villages with parking separate from homes and a network of pathways for pedestrians and bicyclists to encourage physical fitness and increase social interaction.

LT-4.3 Amend Municipal Code to reduce parking ratio requirements for projects located near transit.

LT-4.4 Implement a "park once" strategy by encouraging a range of land uses served by a single parking space.

Goal LT-5: Improve bicycle and pedestrian circulation.

\section{Actions}

LT-5.1 Develop and adopt a Bicycle \& Pedestrian Plan by 2011 to replace the existing Bicycle Master Plan and plan for the necessary requirements to achieve recognition as a Bicycle Friendly Community under the League of American Bicyclists.

a. Identify and prioritize bicycle $\&$ pedestrian improvement projects.

b. Maintenance plan for bicycle and pedestrian infrastructure.

LT-5.2 Provide more Class I off-street bicycle pathways.

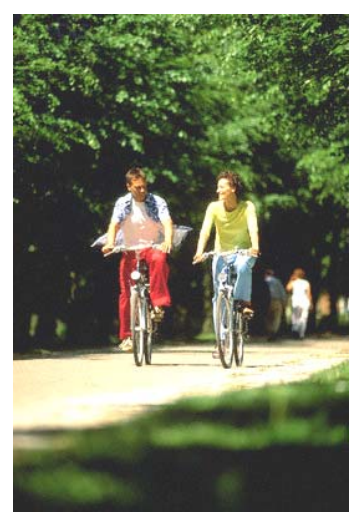

DRs allow the movement of development rights from property important for preservation to other sites more suitable for development. This program allows land to remain available for agricultural uses, wildlife habitat, riparian corridor protection, open space, and other purposes consistent with the principles of sustainability. 


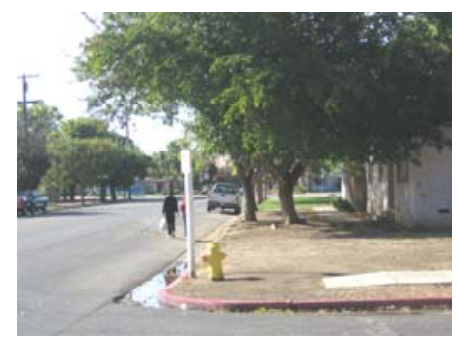

LT-5.3 For "complete streets" with bicycle lanes, improve on-road bicycling conditions (e.g. level pavement surfaces, debris removal, degree of separation from vehicles, way-finding system with signage).

LT-5.4 Provide more bicycle parking at parks, community facilities, retail/commercial areas, employment centers, and other common destinations.

LT-5.5 Complete and repair unfinished sidewalks in and around Downtown.

LT-5.6 Improve lighting and striping (marked crosswalks), and install pedestrian-activated push buttons for signals. Install ground-lights along crosswalks that flash to alert drivers of pedestrians at night (activated by weight sensors) in high-use areas such as Downtown.

LT-5.7 Use textured or raised pavement in retail/commercial areas and other areas of high pedestrian activity.

Goal LT-6: Develop and maintain an interconnected system of parks, open space, and public areas for gathering.

\section{Actions}

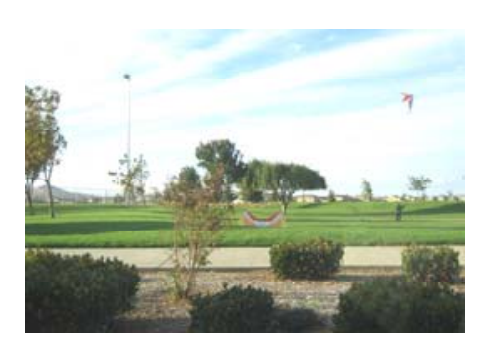

LT-6.1 Increase the amount of publicly accessible and protected green space, waterways, urban creeks, and riparian corridors.

LT-6.2 Establish a greenbelt with recreational trails surrounding the City.

LT-6.3 Amend Municipal Code to require new development to be designed so that all residents live within $\mathrm{l} / 4$ mile of a neighborhood park and $1 / 2$ mile of a community park or recreational open space.

Goal LT-7: Preserve agriculture and agriculture-related operations as an important industry within and around Patterson, and protect agricultural land from urban development.

\section{Actions}

LT-7.1 Establish a permanent 100-foot minimum buffer, or Greenbelt, between urban development within the City and surrounding agricultural lands. Passive recreational access, trails, and native plants should be included in a newly-created transition area.

LT-7.2 Amend Municipal Code to encourage agriculture-related operations such as food processing to the extent that the water supply and wastewater treatment can meet their needs.

CITY of PATTERSON JUNE 2009 SUSTAINABILITY PLAN 
LT-7.3 Amend the Right-to-Farm Ordinance.

a. Require buyers of property adjacent to or near agricultural land to sign a contract at the time of sale, acknowledging and accepting the inconvenience or discomfort inherent to the property's location including, but not limited to, the sounds, odors, dust, smoke, chemicals, and hours of operation that may accompany agricultural uses.

LT-7.4 Establish an Agricultural Advisory Committee as a multijurisdictional alliance to encourage collaboration between landowners, Stanislaus County, nearby cities, StanCOG, the Great Valley Center, local conservancies and non-profit agricultural land trusts, non-governmental organizations such as the American Farmland Trust, Farm Bureau, and other agricultural interest groups to:

a. Seek grant funding.

b. Develop an agricultural land conservancy program to prevent farmland conversion.

c. Coordinate and enforce the mitigation program.

d. Obtain easements or other contracts to protect and preserve farmland and create permanent open space.

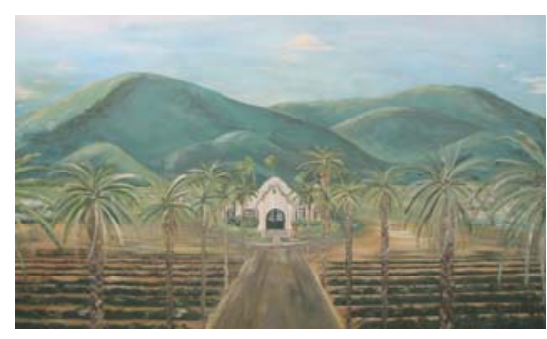

i. Easements: give landowners the option to sell development rights, but retain ownership for uses laid out in a contract overseen by a non-profit organization (e.g. growing crops, grazing, or limited public access). If donated, land becomes tax-exempt.

e. Support continued participation in the Williamson Act program of Agriculture-designated properties within the Planning Area and Sphere of Influence (SOI), thereby providing property tax relief to farmers who volunteer to keep their land in agricultural use.

Goal LT-8: Improve fuel efficiency of the City's Vehicle Fleet.

\section{Actions}

LT-8.1 Require all City-owned vehicles to meet a minimum of 35 miles per gallon (mpg) fuel efficiency by 2015.

LT-8.2 By 2017, convert 100\% of non-emergency City vehicles to electric, hybrid, flex-fuel, or alternative fuels.

LT-8.3 Investigate the "right size" of the City Fleet (de-commission unnecessary vehicles), and minimize the purchase of new vehicles while phasing out older, inefficient vehicles. 
LT-8.4 Require Parks \& Recreation and Public Works Departments to replace gas-powered mowers and other equipment with electric or hybrid models.

LT-8.5 For diesel-powered City vehicles that cannot be replaced with electric, hybrid, or alternative fuel vehicles, install advanced emission control devices, particulate traps, and power inverters that enable equipment to run off batteries without using the engine.

LT-8.6 Whenever possible, use biodiesel fuel (produced from waste oil) for diesel vehicles.

Did you know?

28,000

42-gallon barrels of oil are consumed in the

United States every two minutes (equal to the flow of a mediumsized river)

- chrisjordan.com
In the United States, energy-related activities account for $75 \%$ of humangenerated greenhouse gas emissions (GHGs), generally in the form of carbon dioxide emissions from burning fossil fuels - US EPA
Goal LT-9: Improve fuel efficiency community-wide.

\section{Actions}

LT-9.1 By 2014, develop City infrastructure to support plug-in hybrid and electric vehicle charging stations.

LT-9.2 Utilize only private contractors with green fleets that have cleaner, more efficient vehicles such as electric, hybrid, or alternative fuels (e.g. solid waste \& recycling operations, street sweepers, construction).

LT-9.3 Encourage the use of "preferential parking" for electric, hybrid, and alternative fuel vehicles, as well as carshare, in residential developments and employment centers.

LT-9.4 Consider replacing LOS with a measurement that prioritizes transit, bicycling, and walking before motor vehicles, as its use is merely convention, not law.

LT-9.5 Implement an Automated Traffic Signal Synchronization and Control System (ATSAC).

Goal LT-10: Increase the use of alternative modes of transportation by City employees and employees of commercial and industrial businesses.

\section{Actions}

LT-10.1 Encourage City employees to live locally, participate in rideshare programs, and drive less.

LT-10.2 Offer City employees alternative work schedules and telecommuting (home office) options. Encourage employers to offer similar options.

LT-10.3 Establish a City Employee Alternative Commute Program (e.g. ride-matching) to encourage employees to rideshare, or earn incentives by walking, bicycling, or taking transit. 
LT-10.4 Offer incentives (e.g. discounted transit passes) for City employees who commute by walking, bicycling, and transit. Offer commercial \& industrial employers similar incentives to distribute to employees.

Goal LT-ll: Increase the use of alternative modes of transportation by the general public.

\section{Actions}

LT-11.1 Develop a City-operated Sports Bus ridesharing program (kids going to the community sports complex for weekly athletic games, community pool, proposed community center).

LT-11.2 In the community newsletter and on the City Website, promote the benefits of alternative modes of transportation, and strategies to "Drive Smart:" what to look for when purchasing a car, maintenance (keeping tires inflated) and driving tips (moderate speeds, bundling errands, reduce idling for more than 15 seconds, eliminate quick starts) to maximize fuel efficiency.

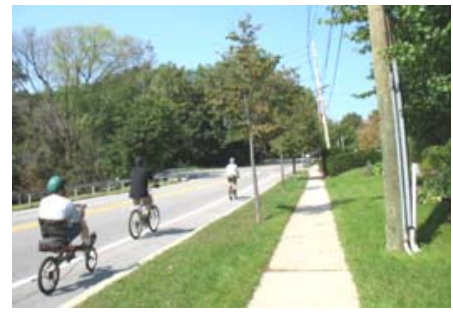

LT-11.3 Encourage residents to drive an electric, hybrid, or other fuelefficient vehicle for personal transportation by marketing state and federal tax incentives in the community newsletter and on the City Website.

LT-11.4 In the community newsletter, as a handout at City Hall and City-sponsored events, and on the City Website, offer a detailed, user-friendly pedestrian and bicycle network map (Patterson's Pathways), and "bicycle confidence" information that teaches traffic laws related to bicycle and pedestrian safety.

LT-11.5 Develop an easy-to-use, web-based ride-matching service for residents, made available on the City website.

LT-11.6 Develop events around, and participate in, National Bike Month (May) and Bike-to-Work Week (counting cyclists), promoted by the League of American Bicyclists.

Goal LT-12: Promote increased public transit ridership.

\section{Actions}

LT-12.1 Encourage expansion of the Dial-a-Ride service.

LT-12.2 Encourage Stanislaus Regional Transit (StaRT) to expand local transit service as ridership increases, and offer fast, frequent, convenient, and reliable bus service. 
LT-12.3 Encourage Stanislaus Regional Transit (StaRT) to provide transit service to the West Patterson Business Park.

LT-12.4 Encourage Stanislaus Regional Transit (StaRT) to offer an Eco-Pass that provides unlimited use. Eco-Pass should be taxdeductible for employers and tax-free for employees and residents.

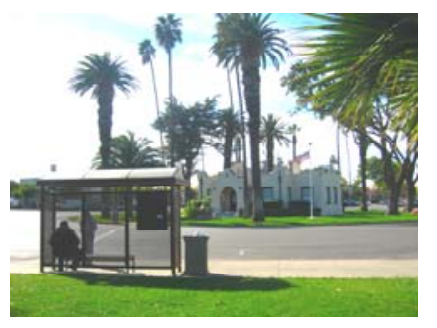

LT-12.5 Encourage StanCOG to increase funding for public transit in

a. Subsidize businesses new to the program for the first year (50\%) to provide all employees with an Eco-Pass.

b. Require new development to offer a fully subsidized EcoPass to its residents for the first year, with a 25\% discounted renewal for the second year.

Patterson. 


\section{MEAsuring PROGRESS}

The following Sustainability Indicators will be monitored annually:

\section{LAND USE}

1. Number of acres of public open space by type (e.g. parks, plazas, gardens) per capita

a. Target: Upward trend

2. Number of miles in the bicycle network

a. Target: Upward trend

3. Percent of total miles of city arterial streets with bike lanes

a. Target: $35 \%$ by 2015

4. Parking ratios in new developments

a. Target: Downward trend

5. Number of carshare preferential parking spaces at municipal and private parking lots

a. Target: Upward trend

\section{TRIP REDUCTION}

6. Household Vehicle Miles Traveled (VMT) measured by model estimates

a. Target: Downward trend

7. Percentage of bicycle and walking trips

a. Target: Upward trend

8. Percentage of all alternative modes combined for commute trips (walk, bike, transit)

a. Target: $25 \%$ by 2015

9. Annual public transit (bus) ridership

a. Target: Upward trend

10. Percentage of City employees using alternative modes for their commute

a. Target: $75 \%$ by 2015

11. Vehicle ownership: average number of vehicles per person of driving age

a. Target: $10 \%$ reduction in the average number of vehicles per person by 2010

\section{Alternative Fuels \& FUEL EFFICIENCY}

12. Percent of City's non-emergency fleet vehicles using electric or hybrid engines or alternative fuels

a. Target: $100 \%$ by 2017

13. Percentage of clean air public transit vehicles

a. Target: $100 \%$ 


\section{LAND USE \& TRANSPORTATION}

\begin{tabular}{|c|c|c|}
\hline No. & ACTION & RESPONSIBILITY \\
\hline LT-1.3 & $\begin{array}{l}\text { Encourage and attract more goods \& services (e.g. clothing stores, } \\
\text { food centers, one-stop-shop retail outlets) to reduce the need to } \\
\text { drive long distances for basic necessities. }\end{array}$ & $\begin{array}{l}\text { - City Council } \\
\text { - Economic Strategic Commission } \\
\text { - Community Development }\end{array}$ \\
\hline $\mathrm{LT}-4.2$ & $\begin{array}{l}\text { Amend Municipal Code to encourage parking in the rear of } \\
\text { buildings. Design residential development to be neighborhood } \\
\text { villages with parking separate from homes and a network of } \\
\text { pathways for pedestrians and bicyclists to encourage physical } \\
\text { fitness and increase social interaction. }\end{array}$ & - Community Development \\
\hline LT-5.1 & $\begin{array}{l}\text { Develop and adopt a Bicycle \& Pedestrian Plan by } 2011 \text { to replace } \\
\text { the existing Bicycle Master Plan and plan for the necessary } \\
\text { requirements to achieve recognition as a Bicycle Friendly } \\
\text { Community under the League of American Bicyclists. } \\
\text { a. Identify and prioritize bicycle \& pedestrian } \\
\text { improvement projects. } \\
\text { b. Maintenance plan for bicycle and pedestrian } \\
\text { infrastructure. }\end{array}$ & - Community Development \\
\hline LT-5.4 & $\begin{array}{l}\text { Provide more bicycle parking at parks, community facilities, } \\
\text { retail/commercial areas, employment centers, and other common } \\
\text { destinations. }\end{array}$ & $\begin{array}{l}\text { - Public Works } \\
\text { - Community Development }\end{array}$ \\
\hline LT-9.1 & $\begin{array}{l}\text { By 2014, develop City infrastructure to support plug-in hybrid and } \\
\text { electric vehicle charging stations. }\end{array}$ & - Community Development \\
\hline LT-11.1 & $\begin{array}{l}\text { Develop a City-operated Sports Bus ridesharing program (kids } \\
\text { going to the community sports complex for weekly athletic games, } \\
\text { community pool, proposed community center). }\end{array}$ & - Parks \& Recreation \\
\hline LT-11.5 & $\begin{array}{l}\text { Develop an easy-to-use, web-based ride-matching service for } \\
\text { residents, made available on the City website. }\end{array}$ & - Webmaster \\
\hline LT-11.6 & $\begin{array}{l}\text { Develop events around, and participate in, National Bike Month } \\
\text { (May) and Bike-to-Work Week (counting cyclists), promoted by } \\
\text { the League of American Bicyclists. }\end{array}$ & - Community Development \\
\hline
\end{tabular}




\section{INTRODUCTION}

For the purpose of this chapter, energy refers to energy use efficiency, energy demand reduction, and renewable energy production. Energy use includes electricity, gas, and motor vehicle fuel. Fuel efficiency of motor vehicles can be found in Chapter I - Land Use \& Transportation. The Energy chapter focuses mainly on buildings because of their high-energy use and the potential for energy demand reduction. According to the U.S. Green Building Council, buildings nationwide account for $70 \%$ of electricity use. Buildings use a great deal of energy for heating (air \& water), cooling, and other functions. According to the California Energy Commission (CEC), the residential sector accounts for more than $32 \%$ of electricity consumption in the state (2006). Almost half of residential energy use is from heating and cooling (Alliance to Save Energy).

The average family in the United States spends about $\$ 1,900 /$ year on home energy bills (Energy Star). Warmer temperatures from climate change may result in higher energy bills for air conditioning in summer months, but the average green building consumes 30\% less energy, resulting in greater cost savings, lower emissions, and better air quality - in addition to many other benefits.

The following Opportunities and Constraints in Patterson should be addressed to improve sustainability:

\section{STRENGTHS \& OPPORTUNITIES}

1. Patterson Aquatic Center utilizes solar heating for the community pool

2. Renewable energy (22.5 megawatts of electricity) produced from the Waste-To-Energy Facility

a. Approximately 3.5 megawatts are consumed for in-house operations and the remaining 19 megawatts (average of 135,500 megawatts annually) is sold to PG\&E to power more than 18,000 homes. Recognized by the State as a renewable source of energy and eligible for the renewable energy portfolio.

3. Turlock Irrigation District (TID), which provides 100\% of the City's electricity, has already exceeded its Renewable Portfolio goal of $20 \%$ by 2017

4. TID offers rebates on Compact Fluorescent Lamp (CFL) purchases, ENERGY STAR ${ }^{\circledR}$ appliances, each new shade tree planted to cool homes in the summer, home installation of photovoltaic (PV) systems, window-covering shade screens, whole house fans, and new residential construction that meets its energy efficiency program requirements

5. Kohl's has already built solar projects and green buildings around the country, something the City should encourage for the distribution center in Patterson 
Did you know? Since CFLs use up to $75 \%$ less energy than incandescent light bulbs, you can easily notice a reduction in your energy bills.

- weather.com

\section{CONSTRAINTS}

1. Building Maintenance Division has only one authorized position (reporting to the Urban Forestry supervisor), making it difficult for energy efficient measures to be implemented in a timely manner

2. No methane recovery system at Fink Road Landfill or at the City's Water Quality Control Facility (WQCF), or wastewater treatment plant, to generate electricity

3. Lack of citywide awareness of the importance of energy efficiency

\section{RECOMMENDATIONS}

The establishment of a Green Building Program is imperative to improve sustainability. Building energy efficient structures when they are first constructed is far more cost-effective than remodeling. LEED (Leadership in Energy and Environmental Design), developed by the United States Green Building Council (USGBC), is the nationally accepted benchmark for the design, construction, and operation of high performance green buildings. LEED promotes a whole-building approach to sustainability by recognizing performance in five areas of human and environmental health: 1) sustainable site development, 2) water savings, 3) energy efficiency, 4) materials selection, and 5) indoor environmental quality. Certification levels are based on total point value: Certified, Silver, Gold, and Platinum. GreenPoint Rated (Build It Green), endorsed by the Home Builders Association of Northern California (HBANC), is for new and existing residential structures, evaluated on five categories: 1) energy efficiency, 2) resource conservation, 3) indoor air quality, 4) water conservation, and 5) community. In addition to environmental benefits, green building will yield social and economic benefits such as long-term savings from reduced operating costs and enhancement of asset value and profits due to improved employee productivity (Great Valley Center).

The City should install renewable energy demonstration projects. Renewable energy includes solar, wind, biogas, geothermal, and other sources. Many cities are developing a Renewable Energy Standard Portfolio, requiring a certain percentage of citywide electricity to be generated from renewable sources. Exercising appropriate marketing techniques, these measures will educate the public on the importance of clean energy.

Energy Audits and retrofits will substantially increase energy efficiency, and can be as easy as replacing light bulbs. Compact florescent lamps (CFLs) are the most cost-effective and efficient lighting option available, lasting 10 times longer than incandescent light bulbs and cutting lighting costs by $75 \%$. It also reduces the need for new energy infrastructure such as power plants and transmission lines. There are state and federal tax incentives available for energy investments, and many efficiency measures do not require any spending (e.g. shorter showers, fully loaded dishwashers, and keeping the door closed during the heating season). 
The following Goals and Actions seek to improve sustainability in Patterson:

\section{OVERALL ENERGY GOALS}

1. Reduce energy use (e.g. electricity, gas) in buildings.

2. Integrate energy efficiency into standard operating procedures for government, residents, and commercial \& industrial businesses.

3. Strive to meet all new demand through energy efficiency and renewable energy sources.

4. Increase the amount of on-site renewable energy projects in Patterson.

\section{GOALS AND ACTIONS}

Goal EE-1: Incorporate sustainable building practices into the City's development regulations.

\section{Actions}

EE-1.1 By 2010, adopt a mandatory Green Building Ordinance for new construction and renovation.

a. Require Build It Green's GreenPoint Rated certification for residential construction and a LEED Silver rating for healthcare facilities and commercial \& industrial construction.

b. Offer flexibility and options to the property owner in determining which materials and techniques meet their needs and desires for complying with the standards.
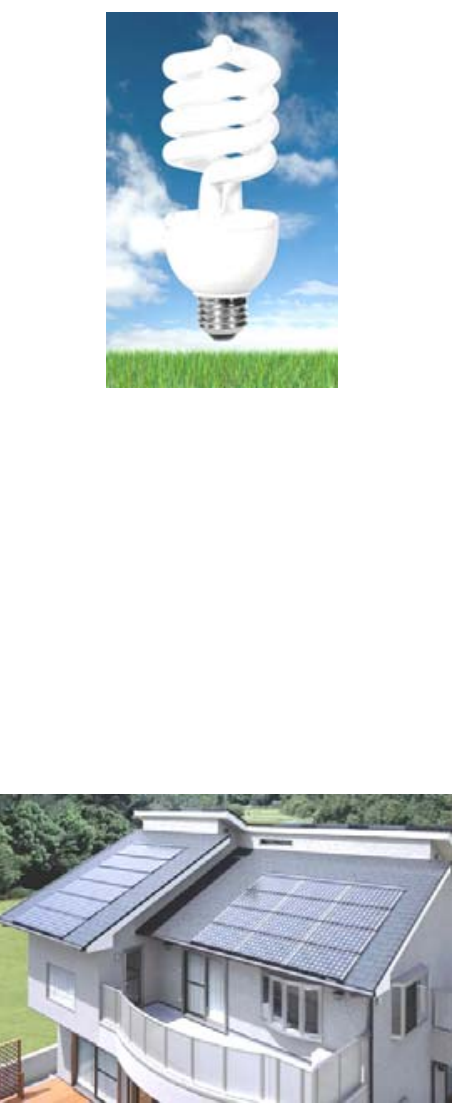

EE-1.2 Encourage passive solar design (passive heating and cooling) to avoid or minimize cooling needs through building orientation of all new development.

EE-1.3 Amend Municipal Code to allow more flexible development standards as incentives for development projects that exceed the minimum requirements for LEED or GreenPoint Rated, such as density bonuses, increased maximum building height, increased Floor Area Ratio (FAR), or a reduced on-site parking requirement.

EE-1.4 Develop financial incentives for new construction projects that are LEED-certified. The incentive rate should increase for each additional point earned.

EE-1.5 Preserve existing structures when feasible, and encourage adaptive reuse.

Did you know? Highly reflective roofs and surfaces can reduce home or building owners' air-conditioning bills by 10 to $50 \%$ They also help make cities cooler and reduce the formation of smog. - US EPA

EE-1.6 Encourage commercial \& industrial businesses to install cool roofs (painted white) or green roofs (with vegetation). 
EE-1.7 Encourage the replacement of inefficient appliances with efficient ones, when there is a change in ownership (or rental).

Goal EE-2: Improve the energy efficiency of City-owned buildings.

\section{Actions}

Did you know?

$45 \%$ of a home's

heat loss comes

from inadequate

insulation.

- Flex Your Power

EE-2.1 By 2020, retrofit all municipal buildings to achieve a minimum of a LEED Silver rating.

EE-2.2 Pursue a LEED Gold rating for the proposed Community Center.

EE-2.3 Pursue green roof (or cool roof) development for City Hall, the proposed Community Center, and all other new municipal buildings.

EE-2.4 Conduct individualized Energy Audits of all City-owned facilities by 2010 and implement cost-effective retrofits by 2011.

a. Purchase super-efficient "80-plus" computers and servers for City facilities.

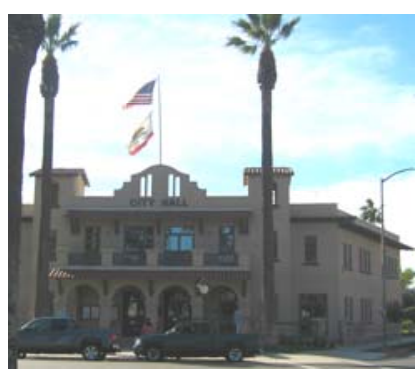

b. Replace thermostats with programmable thermostats.

c. Require the use of timers or daylight and motion sensors.

d. Replace incandescent lighting with LEDs or CFLs.

e. Require linear fluorescent lights to be high efficiency fluorescent fixtures $(\mathrm{T}-8 \mathrm{~s})$.

f. Install vending machine misers.

g. Replace all incandescent traffic signal lights with LED lamps.

Goal EE-3: Improve the energy efficiency of private residences and businesses.

\section{Actions}

EE-3.1 Offer inexpensive individualized Energy Audits for residential and commercial \& industrial buildings, educating occupants on cost-effective retrofits.

a. Train City staff for Energy Audits to reduce "energy leaks" and provide direct installation \& technical assistance.

b. Partner with California Youth Energy Services (CYES) and the Patterson Joint Unified School District (PJUSD) to train high school juniors \& seniors to volunteer their time in the summer for Energy Audits to reduce "energy leaks" as part of a home weatherization program that 
provides direct installation and technical assistance for low-income residents and seniors before all other residents.

c. Encourage early replacement of old, inefficient appliances with new, more efficient Energy Star-certified refrigerators, washer/dryers, water heaters, furnaces, and electric heating and natural gas appliances.

d. Encourage the replacement of incandescent light bulbs with LEDs or CFLs, and high efficiency fluorescent fixtures (T-8s) for linear fluorescent lights.

e. Encourage the replacement of thermostats with programmable thermostats.

f. Encourage the use of timers or daylight and motion sensors.

g. Encourage the purchase of super-efficient "80-plus" computers and servers.

h. Encourage the installation of vending machine misers.

EE-3.2 Encourage TID to adopt seasonal "time of use" billing rates that offer lower rates for electric usage during off-peak hours than during peak hours.

Goal EE-4: Promote the development of on-site renewable energy (e.g. solar, wind, biomass, and geothermal).

\section{Actions}

EE-4.1 Conduct a feasibility study to explore the possibility of installing a methane recovery system at the City's Water Quality Control Facility (WQCF), or wastewater treatment plant, to generate electricity.

EE-4.2 Amend Municipal Code to streamline the approval of solar panels and small-scale wind turbines. Protect light access for solar energy systems.

EE-4.3 Offer a Solar Fee Waiver for any building permit application fees related to the installation of solar panels.

EE-4.4 Implement a Solar Roof Program under Property Assessed Clean Energy to minimize upfront costs for installing solar panels on residential and non-residential buildings. The landowner will pay an annual 'special assessment' property tax.
Did you know? In 2008, Americans saved $\$ 19$ billion on their utility bills by becoming more energy efficient, avoiding greenhouse gas emissions equivalent to those from 29 million cars. - Energy Star

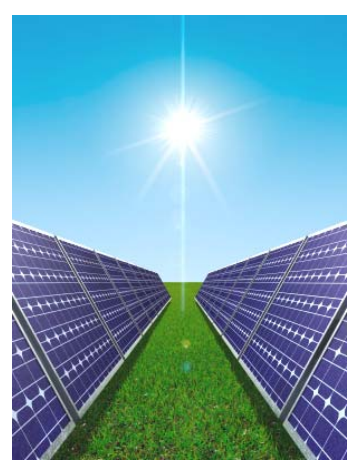


EE-4.5 Encourage installation and private funding of on-site renewable energy projects in Patterson, e.g. homes; roofs and parking lot solar photovoltaic arrays in the West Patterson Business Park and in commercial centers providing a large area for solar panels, and providing shade for vehicles.

EE-4.6 Collaborate with large landowners, including surrounding agricultural uses in Stanislaus County, to encourage

Did you know? Every minute, 320,000 kilowatt hours of electricity is wasted in the United States from inefficient residential electricity usage (inefficient wiring, computers in sleep mode, etc.) - chrisjordan.com

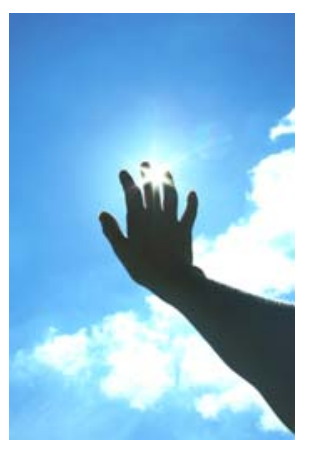

installation and funding of on-site renewable energy projects.

EE-4.7 Encourage the Stanislaus County Environmental Resources Department to install a methane recovery system at the Fink Road Landfill to generate electricity.

Goal EE-5: Increase public awareness of energy-saving measures.

\section{Actions}

EE-5.1 Provide green building and energy efficiency training.

a. Provide LEED and GreenPoint Rated (GPR) training for two key Planning \& Building staff to offer consulting services (for a fee) to applicants.

b. Join the Local Government Sustainable Energy Coalition (LGSEC) to ensure that training includes the latest technology and best practices.

c. Hold a voluntary meeting for developers, architects, designers, contractors, and building operators, informing them of the benefits of green building and the upcoming requirements of the Green Building Ordinance.

d. Hold a voluntary meeting for real estate agents to encourage the marketing of Build It Green's GreenPoint Seal on new and existing for-sale homes.

e. Provide an energy efficiency workshop for Planning Commission, City Council, and the Economic Strategic Commission, the Chamber of Commerce, designers, contractors, and building operators.

f. Make energy efficiency presentations at schools and neighborhood organization meetings.

EE-5.2 Install demonstration projects (e.g. solar) at City facilities and schools to serve as educational displays with permanent interpretive panels that teach about the building's use of green technology. 
EE-5.3 In the community newsletter and on the City website, advertise and link to the energy efficiency and renewable energy rebates offered by TID, PG\&E, the Great Valley Solar Partnership, and the state and federal governments.

Collaborate with TID, PG\&E, and the Great Valley Solar Partnership to pool funding resources to help spread the word with ads on local television.

EE-5.4 Create a friendly competition among cities within Stanislaus County, tracking annual solar installations. Publicize it in utility billing notices, the community newsletter, and the City website.

EE-5.5 Encourage PG\&E and TID to allow individual energy customers to easily access their energy use information to enable modified behavior to cut costs by becoming more energy efficient. Explore the feasibility of partnering with Google for the smart meter project. 


\section{MeAsuring Progress}

The following Sustainability Indicators will be monitored annually:

\section{GREEN BUILDING}

1. Percentage of all new construction that is LEED-certified (Silver, Gold, or Platinum)

a. Target: $30 \%$ for $2012 ; 80 \%$ for 2030 .

2. Number of buildings obtaining LEED Silver certification

a. Target: Upward trend

3. Number of green roofs or cool roofs

a. Target: 10 green roofs and 10 cool roofs by 2012

\section{ENERGY EFFICIENCY / DEMAND REDUCTION}

4. Per capita residential energy use (both gas and electric)
a. Target: For 2015, reduction of $15 \%$ compared to baseline year of 2010

5. Total citywide energy use (by sector)

a. Target: Downward trend

\section{RENEWABLE ENERGY}

6. Percent of citywide energy generated by renewable sources

a. Target: $20 \%$ by $2015 ; 33 \%$ by 2020

7. Annual solar installations within the City

a. Target: 100 by 2012 


\section{Mid-Term Phasing \& Implementation}

\begin{tabular}{|c|c|c|}
\hline No. & ACTION & RESPONSIBILITY \\
\hline EE-1.1 & $\begin{array}{l}\text { By } 2010 \text {, adopt a mandatory Green Building Ordinance for new } \\
\text { construction and renovation. }\end{array}$ & $\begin{array}{l}\text { - City Council } \\
\text { - Community Development }\end{array}$ \\
\hline EE-2.4 & $\begin{array}{l}\text { Conduct individualized Energy Audits of all City-owned facilities } \\
\text { by } 2010 \text { and implement cost-effective retrofits by } 2011 \text {. }\end{array}$ & - Public Works \\
\hline EE-3.1 & $\begin{array}{l}\text { Offer inexpensive individualized Energy Audits for residential and } \\
\text { commercial \& industrial buildings, educating occupants on cost- } \\
\text { effective retrofits. }\end{array}$ & - Public Works \\
\hline EE-3.2 & $\begin{array}{l}\text { Encourage TID to adopt seasonal "time of use" billing rates that } \\
\text { offer lower rates for electric usage during off-peak hours than } \\
\text { during peak hours. }\end{array}$ & - Community Development \\
\hline EE-4.1 & $\begin{array}{l}\text { Conduct a feasibility study to explore the possibility of installing a } \\
\text { methane recovery system at the City's Water Quality Control } \\
\text { Facility (WQCF), or wastewater treatment plant, to generate } \\
\text { electricity. }\end{array}$ & - Community Development \\
\hline $\mathrm{EE}-4.2$ & $\begin{array}{l}\text { Amend Municipal Code to streamline the approval of solar panels } \\
\text { and small-scale wind turbines. Protect light access for solar energy } \\
\text { systems. }\end{array}$ & $\begin{array}{l}\text { - City Council } \\
\text { - Community Development }\end{array}$ \\
\hline $\mathrm{EE}-4.5$ & $\begin{array}{l}\text { Encourage installation and private funding of on-site renewable } \\
\text { energy projects in Patterson, e.g. homes; roofs and parking lot solar } \\
\text { photovoltaic arrays in the West Patterson Business Park and in } \\
\text { commercial centers providing a large area for solar panels, and } \\
\text { providing shade for vehicles. }\end{array}$ & - Community Development \\
\hline EE-5.1.a & $\begin{array}{l}\text { Provide LEED and GreenPoint Rated (GPR) training for two key } \\
\text { Planning \& Building staff to offer consulting services (for a fee) to } \\
\text { applicants. }\end{array}$ & - Community Development \\
\hline $\mathrm{EE}-5.2$ & $\begin{array}{l}\text { Install demonstration projects (e.g. solar) at City facilities and } \\
\text { schools to serve as educational displays with permanent } \\
\text { interpretive panels that teach about the building's use of green } \\
\text { technology. }\end{array}$ & $\begin{array}{l}\text { - Public Works } \\
\text { - Community Development }\end{array}$ \\
\hline EE-5.5 & $\begin{array}{l}\text { Encourage PG\&E and TID to allow individual energy customers to } \\
\text { easily access their energy use information to enable modified } \\
\text { behavior to cut costs by becoming more energy efficient. Explore } \\
\text { the feasibility of partnering with Google for the smart meter } \\
\text { project. }\end{array}$ & - Public Works \\
\hline
\end{tabular}




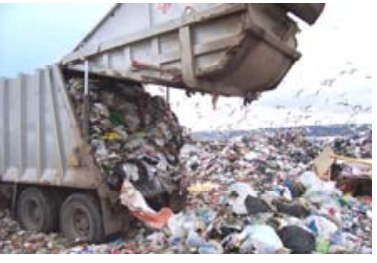

\section{WASTE REDUCTION \& RECYCLING}

\section{INTRODUCTION}

Waste reduction is essential to improving sustainability by reducing the amount of solid waste taken to the landfill, which produces greenhouse gas emissions (methane) and requires more truck trips to the landfill. It also decreases the amount of land needed to accommodate our trash.

The following Opportunities and Constraints in Patterson should be addressed to improve sustainability:

\section{STRENGTHS \& OPPORTUNITIES}

1. Waste-To-Energy Facility diverts $70 \%$ of Patterson's waste from the landfill, saving valuable space and prolonging the life of the landfill

2. As a member of the Stanislaus County Regional Solid Waste Planning Agency, Patterson has a 61\% diversion rate, exceeding the state-mandated 50\%

3. Stanislaus Resource Recovery Facility (SRRF) recycles an average of 5,400 tons of ferrous metals annually

4. Curbside garbage, green waste (e.g. lawn clippings, trimmed tree branches, leaves, weeds), and recycling program

5. Polystyrene (Styrofoam) is recyclable in Patterson

6. Used oil and oil filters can be disposed of at local auto care facilities

7. TID offers help recycling old refrigerators

\section{CONSTRAINTS}

1. Food waste is not recycled in Patterson (composting facilities are not available locally)

2. Batteries must be taken to the Modesto Collection Facility, which is 17 miles (and 39 minutes) away, or to a mobile collection event held only twice a year, for HHW and E-Waste.

3. Construction $\&$ demolition waste is taken to the landfill rather than recycled

\section{RECOMMENDATIONS}

Increasing the practice of alternative disposal methods such as recycling and composting are equally as important as producing less waste through thoughtful product purchasing. Recycling is an easy way to reduce the amount of solid waste going to the landfill, while providing raw materials for manufacturing companies and jobs for the local economy. Composting is an effective way of re-using food waste in the garden and minimizing the amount taken to the landfill. Most importantly, the City, in collaboration with waste collection services, should conduct extensive outreach to residents and businesses to educate the public.

The following Goals and Actions seek to improve sustainability in Patterson: 


\section{GOALS AND ACTIONS}

$\begin{array}{ll}\text { Goal WR-1: } & \begin{array}{l}\text { Incorporate policies into Municipal Code that promote } \\ \text { reduced generation of solid waste. }\end{array}\end{array}$

Actions

WR-1.1 Adopt a mandatory Construction \& Demolition (C\&D) Ordinance, as part of the Green Building Ordinance (Action EE-1.1), requiring all new development projects to submit a plan to recycle a minimum of $60 \%$ of construction and demolition waste.

a. Review and increase the minimum recycling rate periodically as $C \& D$ processes and markets improve.

b. Assist contractors in locating Materials Recovery Facilities (MRFs), materials exchange opportunities, and other reuse and recycling resources.

WR-1.2 In partnership with local businesses, impose a 25-cent fee on paper and plastic shopping bags at grocery, drug, and convenience stores. Impose a ban for 2012.

a. Retailers will receive 10 -cents of each fee for administrative costs, while the rest will be collected by the City to implement policies improving sustainability.

WR-1.3 Adopt an ordinance banning foam containers (e.g. plates, meat trays, egg cartons, and hot \& cold beverage cups), disposable plastic or plastic-coated paper products, and nonrecyclable materials in restaurants, food centers, and retail stores. Encourage food service industry (restaurants, delicatessens, fast food outlets, coffee shops, and grocery stores) to convert to packaging that is biodegradable (compostable) or locally recyclable. Adopt an ordinance making it mandatory for 2012.

WR-1.4 Ban the sale of incandescent bulbs and non-rechargeable batteries.

WR-1.5 Encourage Stanislaus County to ban plastic disposables, plastic peanuts, and expanded polystyrene disposables from the landfill, as well as yard waste, wood furniture, paper, cardboard, glass, metal, and other easily recyclable materials. Ban treated wood (e.g. furniture) from the landfill and require it to be stripped and recycled. Issue fines for noncompliance found by landfill operators and through waste audits (refer to Action WR-6.2 below).
Did you know?

Americans use 1.14 million brown paper supermarket bags every hour. chrisjordan.com

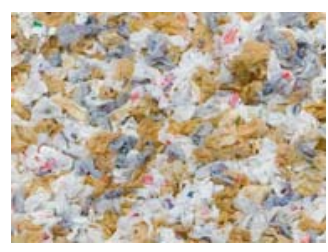

Did you know? Americans use 60,000 plastic bags every 5 seconds. - chrisjordan.com

Did you know? 410,000 disposable hot-beverage paper cups are used every 15 minutes in the US. chrisjordan.com 


\section{Goal WR-2: Reduce the generation of solid waste from City} operations.

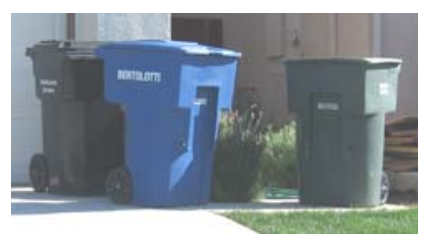

\section{Actions}

WR-2.1 On the City website, allow residents to securely view statements and pay online for business licenses, permits, parking citations, and utility services: water, sewer, refuse.

WR-2.2 Develop an Environmentally-Preferred Purchasing Policy for the City to integrate waste reduction solutions into purchasing and investment decisions, and decrease consumption of non-local, non-renewable, and non-recyclable materials.

a. Ban the use of City funds to purchase single-serving plastic bottled water.

b. In place of conventional products, purchase durable and long-lasting products with recycled and biodegradable content, that reduce energy and water use, reduce greenhouse gas emissions, and use non-toxic, unbleached, chlorine-free manufacturing processes.

Americans use 4 million plastic bottles every hour, but only 1 in 4 is recycled. Fill up a reusable bottle,

because bottled water isn't always cleaner, and the production, shipment, and disposal of plastic water bottles are taking an enormous toll on the environment. - weather.com

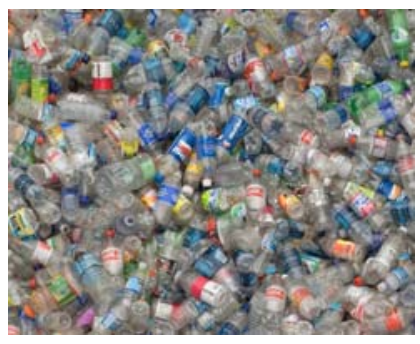

WR-2.3 Adopt a "zero waste" policy for public events (e.g. Farmer's Market, Apricot Fiesta), reusing or recycling as much waste as possible.

WR-2.4 Establish an online permitting system via the City website to allow electronic submittal, reduce application paperwork, and require large-scale printed plans only when necessary. Applicants should also be able to view application status.

Goal WR-3: Increase the recycling rate in residential neighborhoods.

\section{Actions}

WR-3.1 Ensure that recycling bins are provided at all public parks and multi-family buildings.

WR-3.2 Ensure local recycling facilities are available to the public.

WR-3.3 Establish a permanent local collection center / recycling facility for Household Hazardous Waste (HHW) and ewaste such as batteries, computers, and other electronics. 
Goal WR-4: Increase the recycling rate for commercial and industrial businesses.

\section{Actions}

WR-4.1 Adopt a Business Recycling Ordinance requiring 30\% diversion of commercial waste.

a. Require a plan from businesses outlining strategies to increase commercial recycling and meet the diversion requirement.

Did you know? Americans use 2 million plastic beverage bottles every 5 minutes. chrisjordan.com

WR-4.2 Require a plan from each private refuse hauler to increase commercial recycling as a condition of contract. Require haulers to achieve a minimum recycling rate, such as the statemandated $50 \%$ presently required of cities.

WR-4.3 Promote reuse to businesses (and residents) by encouraging thrift shops, reuse stores, and materials exchange programs (i.e. swap meets) with a focus on furniture and clothing. One person's trash is another person's treasure.

WR-4.4 Establish Outstanding Recycler Awards for businesses.

WR-4.5 In partnership with local businesses, encourage and promote the use of reusable shopping bags and recyclable food service ware in place of food service plastics.

WR-4.6 Encourage food processing operations to donate food waste to nearby cattle feed lots.

WR-4.7 Encourage businesses to offer electronic (email) billing and sales receipts as an alternative to paper bills and sales receipts.

Goal WR-5: Increase the composting of organic waste.

\section{Actions}

WR-5.1 Ensure that a local composting facility is available.

WR-5.2 Improve convenient curbside collection of "green bin" materials to include food waste, animal bedding, and soiled paper, in addition to yard debris.

WR-5.3 Encourage residents to separate and collect food scraps, which can be thrown into the green bin for pick-up along with yard waste.

WR-5.4 In the community newsletter and on the City website, promote the use of "backyard bins" for home composting to break down biodegradable materials, for grass-cycling and mulching. 
WR-5.5 Establish incentives for restaurants and other businesses to recycle food waste such as grease (e.g. can be used for biofuel).

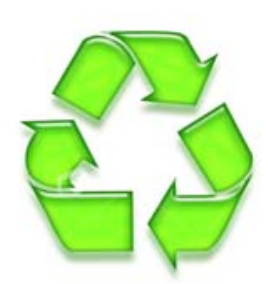

Goal WR-6: Increase public awareness of waste reduction and recycling.

\section{Actions}

WR-6.1 Set volume-based garbage collection fees in a "pay-as-youthrow" program.

a. Cost for curbside collection is based on how much is recycled and how much is thrown away. The more you recycle, the less you pay.

WR-6.2 Implement a waste audit program for residents and businesses to enforce recycling habits.

a. Trash bins and dumpsters will be screened at random.

Violators will be tracked in a database. After one warning, a fine will be issued for any future wrongful disposal of recyclables.

WR-6.3 In the community newsletter and on the City website, encourage residents to switch to electronic (email) billing view statements and pay online for TV, phone, and Internet service.

Did you know?

Americans use

106,000 aluminum

cans every 30

seconds.

- chrisjordan.com

WR-6.4 In the City newsletter, waste services' electronic billing notices, and on the City website, educate people on how and where to recycle paper, cardboard, glass, metal, plastic, yard debris, food scraps, textiles, and other materials. Emphasize the not-so-obvious recyclables such as plastic bags and Polystyrene/Styrofoam.

WR-6.5 In the City newsletter, waste services' electronic billing notices, and on the City website, promote reuse before recycling, recycling sales receipts, and the use of rechargeable batteries.

WR-6.6 Provide composting workshops. 


\section{MEASURING PROGRESS}

In addition to reviewing reports from contracted waste collection services, the following Sustainability Indicators will be monitored annually:

\section{WASTE REDUCTION}

1. Solid waste generation per capita

a. Target: Do not exceed year 2000 levels by 2010

2. Percentage of solid waste diverted from landfill (City Operations)

a. Target: $90 \%$ by 2015

3. Percentage of solid waste diverted from landfill (Community-wide)

a. Target: $70 \%$ by 2015

\section{RECYCLING \& COMPOSTING}

1. Number of participants in the composting program

a. Target: Upward trend

2. Percentage of construction \& demolition waste recycled (per company / per project), thereby diverted from the landfill

a. Target: At least 60\% 


\section{Mid-Term Phasing \& Implementation}

\begin{tabular}{|c|c|c|}
\hline No. & ACTION & RESPONSIBILITY \\
\hline WR-1.1 & $\begin{array}{l}\text { Adopt a mandatory Construction \& Demolition (C\&D) } \\
\text { Ordinance, as part of the Green Building Ordinance (Action EE- } \\
\text { 1.1), requiring all new development projects to submit a plan to } \\
\text { recycle a minimum of } 60 \% \text { of construction and demolition } \\
\text { waste. }\end{array}$ & $\begin{array}{l}\text { City Council } \\
\text { Community Development }\end{array}$ \\
\hline WR-1.2 & $\begin{array}{l}\text { In partnership with local businesses, impose a } 25 \text {-cent fee on } \\
\text { paper and plastic shopping bags at grocery, drug, and } \\
\text { convenience stores. Impose a ban for } 2012 \text {. }\end{array}$ & $\begin{array}{l}\text { City Council } \\
\text { Community Development }\end{array}$ \\
\hline WR-1.3 & $\begin{array}{l}\text { Adopt an ordinance banning foam containers (e.g. plates, meat } \\
\text { trays, egg cartons, and hot \& cold beverage cups), disposable } \\
\text { plastic or plastic-coated paper products, and non-recyclable } \\
\text { materials in restaurants, food centers, and retail stores. } \\
\text { Encourage food service industry (restaurants, delicatessens, fast } \\
\text { food outlets, coffee shops, and grocery stores) to convert to } \\
\text { packaging that is biodegradable (compostable) or locally } \\
\text { recyclable. Adopt an ordinance making it mandatory for } 2012 \text {. }\end{array}$ & $\begin{array}{l}\text { City Council } \\
\text { Community Development }\end{array}$ \\
\hline WR-1.4 & $\begin{array}{l}\text { Ban the sale of incandescent bulbs and non-rechargeable } \\
\text { batteries. }\end{array}$ & $\begin{array}{l}\text { City Council } \\
\text { Community Development }\end{array}$ \\
\hline WR-2.1 & $\begin{array}{l}\text { On the City website, allow residents to securely view } \\
\text { statements and pay online for business licenses, permits, } \\
\text { parking citations, and utility services: water, sewer, refuse. }\end{array}$ & Webmaster \\
\hline WR-2.2 & $\begin{array}{l}\text { Develop an Environmentally-Preferred Purchasing Policy for the } \\
\text { City to integrate waste reduction solutions into purchasing and } \\
\text { investment decisions, and decrease consumption of non-local, } \\
\text { non-renewable, and non-recyclable materials. } \\
\text { a. Ban the use of City funds to purchase single-serving plastic } \\
\text { bottled water. }\end{array}$ & $\begin{array}{l}\text { City Council } \\
\text { City Manager's Office } \\
\text { Community Development }\end{array}$ \\
\hline WR-3.2 & Ensure local recycling facilities are available to the public. & Community Development \\
\hline WR-4.4 & Establish Outstanding Recycler Awards for businesses. & City Council \\
\hline WR-6.1 & $\begin{array}{l}\text { Set volume-based garbage collection fees in a "pay-as-you- } \\
\text { throw" program. } \\
\text { a. Cost for curbside collection is based on how much is } \\
\text { recycled and how much is thrown away. The more you } \\
\text { recycle, the less you pay. }\end{array}$ & City Council \\
\hline
\end{tabular}




\section{INTRODUCTION}

The City needs to provide residents with a reliable supply of clean water. This can be achieved by relying on a diverse set of sources, and reducing water consumption to lower demand and the energy associated with the conveyance and treatment of water. An estimated 19\% of California's energy use is associated with the pumping, moving, and treatment of water (Flex Your Power). Allowing groundwater aquifers to recharge ensures the availability of water for future generations. Water conservation can reduce wastewater treatment costs, reduce greenhouse gas emissions, and improve air quality. The City should also pursue recycled water and storm water capture to lower demand.

In a warming climate, there may be less precipitation, increased evaporation, and drier soil. Extreme events like floods and droughts are likely to become more frequent, which will affect water quality and availability. For example, increases in drought in some areas may increase the frequency of water shortages and lead to more restrictions on water usage (US EPA).

The following Opportunities and Constraints in Patterson should be addressed to improve sustainability:

\section{STRENGTHS \& OPPORTUNITIES}

1. City maintains 4.5 millions gallons of water storage at its three pump stations/storage tanks and six operational wells

2. Nearly all water services in Patterson are metered on a monthly basis, leaving the potential to measure water use by sector (residential, commercial, industrial, landscaping, etc.)

3. City has a Water Conservation Control mobile (truck) unit, performing inspections and repairs to ensure water conservation

4. City website displays water conservation methods, recommended efficient plumbing fixtures, recommended drought-tolerant and low water-use trees and plants, and the Landscaping Watering Schedule required by Municipal Code

5. Municipal Code requires $90 \%$ drought-tolerant plants, underground irrigation must reduce water waste, planting and irrigation system design standards for new development, and preparation of landscape and irrigation plans

6. City conducted a Non-Potable Water Master Plan and Feasibility Study in July 2008

7. City has adopted a Drought Contingency Plan

\section{CONSTRAINTS}

1. Lack of diversity in the City's water sources (supply comes only from the groundwater aquifer)

2. City has no surface water entitlements

3. Groundwater quality and quantity are both limited (high level of salinity) 


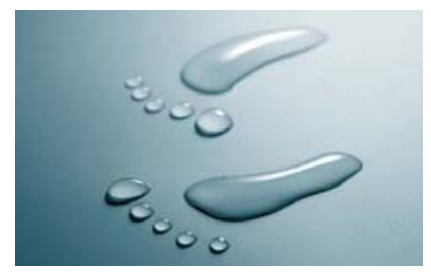

4. City is reviewing potential General Plan scenarios that could expand the population by more than three times by 2028 , requiring a substantial amount of additional water (City may be required to provide treatment in the near future)

5. City is expected to deplete the available supply of groundwater meeting Domestic Water Quality Standards sometime in the near future

6. Most projections indicate that less water will be available in the future, due to climate change

7. The cost of delivering water will increase substantially in the next 15 to 30 years; Patterson will experience impacts more severely than most water purveyors (Villages of Patterson EIR)

\section{RECOMMENDATIONS}

Long-term water security can be achieved by gaining rights to additional water sources, beyond groundwater, and by improving the efficiency with which existing supplies are used. In order to maximize water efficiency and conservation, the City should perform residential and business Water Audits and fully implement the Non-Potable Water Master Plan (i.e. recycled water for landscaping). The City should also conduct an extensive outreach program to encourage water conservation through such measures as upgrading fixtures. Once outreach has begun, the City should phase in and adopt a usage-based fee system for water service.

The following Goals and Actions seek to improve sustainability in Patterson:

\section{OVERALl GoAls}

1. Secure a reliable long-term supply of high quality water sources.

2. Increase water use efficiency to reduce overall water demand.

3. Reduce per capita water consumption $25 \%$ by 2020 .

4. Reduce the water consumed for park irrigation by $40 \%$ by 2020.

Did you know? Per capita water use is higher in hotter, inland regions than in cooler, coastal locations. - saveourh2o.org (ACWA)

\section{GOALS AND ACTIONS}

Goal WC-1: Reduce overall municipal water use.

\section{Actions}

WC-1.1 City staff (Water Conservation Control) will conduct individualized Water Audits (inspection program performed simultaneously with Energy Audits).

a. Assess current indoor and outdoor water usage at all public buildings and public facilities (e.g. parks). Identify, repair, and eliminate leaks. Retrofit all public buildings with cost-effective water-saving features.

b. Continue enforcement of the Landscaping Watering Schedule (provided on the City website), implementing Ordinance 13.24.240 - Negligent Waste of Water. 
c. Offer inexpensive Water Audits to private residences and businesses to assess current indoor and outdoor water usage and educate occupants on cost-effective retrofits.

d. Conduct Landscape Audits of large commercial \& industrial businesses to ensure compliance with Municipal Code Chapter 15.48 (drought-tolerant landscaping).

WC-1.2 Incorporate water conservation into the practice of sustainable park design and maintenance at all City facilities, parks, streetscapes, medians, and open space areas.

a. Install weather-based irrigation controllers (Automated Irrigation System).

b. Install drip irrigation systems to reduce runoff and evaporation.

c. Plant, grow, and maintain sustainable landscaping (i.e. regionally-appropriate drought-tolerant native plant species and grasses or Xeriscape landscape concepts).

d. Implement the Non-Potable Water Master Plan to use recycled water for park irrigation.

e. Explore the feasibility of installing bioswales and proper drainage for stormwater purification.

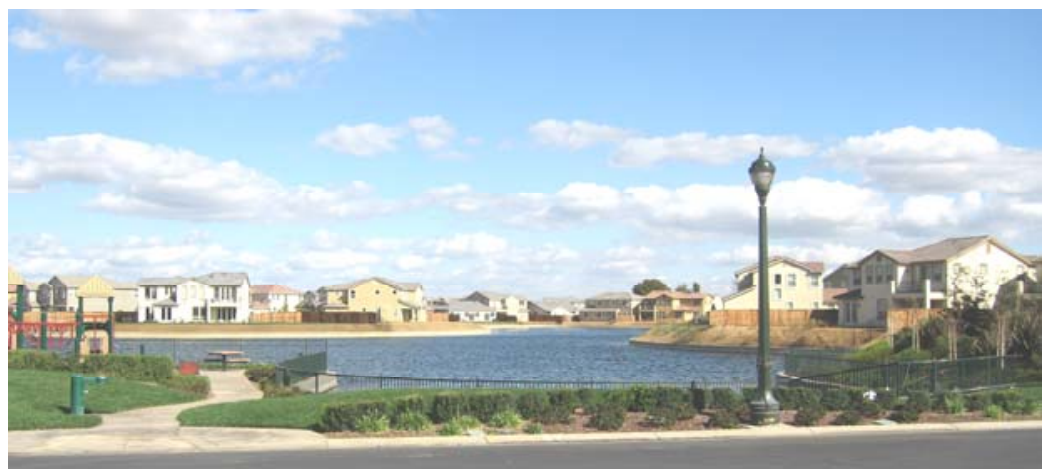

WC-1.3 Continue as an active member of the California Urban Water Conservation Council (CUWCC), pledging to develop and implement comprehensive conservation Best Management Practices (BMPs).

WC-1.4 Collaborate with Homeowners Associations (HOAs) to encourage residents to install cost-effective water-saving features and help enforce timing of residential water use, and use of regionally-appropriate drought-tolerant landscaping, recognizing that education should precede penalty.

WC-1.5 Encourage commercial \& industrial businesses to install drip irrigation systems to replace conventional sprinkler systems, which will reduce runoff and evaporation, as part of the Green Business Certification program. 
WC-1.6 Encourage businesses to use recycled water for commercial \& industrial landscape irrigation, as part of the Green Business Certification program.

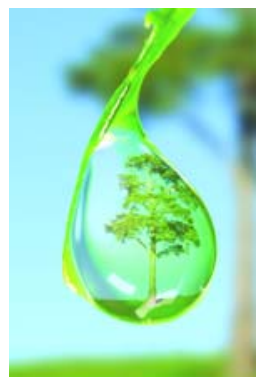

Goal WC-2: Incorporate policies into Municipal Code that promote water conservation.

\section{Actions}

WC-2.1 Adopt a usage-based fee system (tiered rate structure) to encourage efficient residential and commercial $\&$ industrial water use. Customers will be awarded a lower cost for consuming less, with increasing cost as consumption increases, and will pay a penalty fee when exceeding a certain amount of water usage.

WC-2.2 Adopt an ordinance requiring the installation of water efficient plumbing fixtures for existing buildings when properties change ownership/lessee (e.g. adding aerators to faucets, high-efficiency clothes washers and dish washers, low-flush toilets, low-flow faucets and showerheads, waterless urinals).

WC-2.3 Amend Municipal Code Chapter 15.48 to require 100\% (in place of the current 90\%) of all trees and plants to be droughttolerant and low-water use, selected from an approved tree and plant list, which will include regionally-appropriate drought-tolerant native plants and trees with optimal carbon sequestration characteristics.

WC-2.4 Establish a permitting process and amend Municipal Code to allow the use of residential rainwater collection systems (e.g. rainwater barrels capturing water runoff from roofs), and encourage graywater systems for non-potable uses such as commercial \& industrial rainwater collection systems for the harvesting, storing, and use of rainwater from roof surfaces for on-site landscaping irrigation and fire suppression.

Goal WC-3: Secure a stable, balanced portfolio and a reliable longterm supply of high quality water sources.

\section{Actions}

WC-3.1 Acquire surface water rights from one of the three water districts.

WC-3.2 Approve new development only when a reliable and adequate water supply can be proven to serve it in the long-term.

WC-3.3 Avoid the need for construction of new potable water treatment facilities, to the extent feasible. 
WC-3.4 For City projects, use permeable paving materials and products that filter surface runoff and aid in groundwater recharge.

WC-3.5 Explore the feasibility and develop locations for stormwater infiltration to recharge groundwater aquifers, and stormwater capture \& reuse.

WC-3.6 Preserve and protect current and future potential drinking water sources (e.g. groundwater aquifers, Delta Mendota Canal).

WC-3.7 Investigate opportunities for water banking (i.e. use less and sell the water rights).

Goal WC-4: Increase public awareness of water conservation measures.

\section{Actions}

WC-4.1 Provide water conservation and drought-tolerant landscaping training for Public Works employees and the Parks \& Recreation Commission.

WC-4.2 Provide water conservation training for Building Division employees, with an emphasis on water-efficient design and plumbing fixture upgrades.

WC-4.3 Allow individual water customers to easily access their water use information to encourage the installation of cost-effective water-saving features and enable modified behavior to cut costs through water use efficiency.

WC-4.4 In the community newsletter, in water services' electronic billing notices, and on the City website, encourage residents and businesses to save money and conserve water by upgrading to water-saving fixtures and appliances. Explain the importance of their actions, the benefits, proper use of graywater and recycled water, and notify them of the upcoming tiered rate structure and inexpensive Water Audits.

WC-4.5 Continue providing valuable water conservation tips on the City website.

WC-4.6 Offer landscape workshops on drought-tolerant native trees and plants.

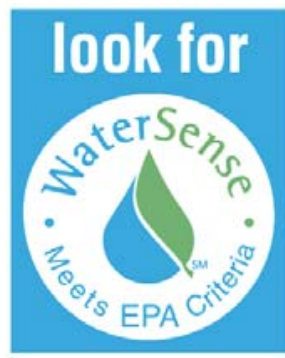

WC-4.7 Place signage (flags on streetpoles) around the City highlighting water conservation and native landscaping efforts. 


\section{MEASURING PROGRESS}

The following Sustainability Indicators will be monitored annually:

\section{WATER CONSERVATION}

1. Total citywide water use per capita

b. Target: $25 \%$ reduction by 2020

2. Total citywide water use by sector (tracked via water bill statements)

c. Target: Downward trend

3. Number of permits issued for residential and commercial \& industrial rainwater collection systems

d. Target: Upward trend

4. Number of permits issued for graywater systems

e. Target: Upward trend

5. Percent of new or replaced, public landscaped area with regionallyappropriate plants.

f. Target: $100 \%$ by 2011 


\section{Mid-Term Phasing \& Implementation}

\begin{tabular}{|l|l|l|}
\hline No. & \multicolumn{1}{|c|}{ ACTION } & \multicolumn{1}{|c|}{ RESPONSIBILITY } \\
\hline WC-1.1 & $\begin{array}{l}\text { City staff (Water Conservation Control) will conduct } \\
\text { individualized Water Audits (inspection program performed } \\
\text { simultaneously with Energy Audits). }\end{array}$ & - Public Works \\
\hline WC-2.1 & $\begin{array}{l}\text { Adopt a usage-based fee system (tiered rate structure) to } \\
\text { encourage efficient residential and commercial \& industrial water } \\
\text { use. Customers will be awarded a lower cost for consuming less, } \\
\text { with increasing cost as consumption increases, and will pay a } \\
\text { penalty fee when exceeding a certain amount of water usage. }\end{array}$ & - City Council \\
\hline WC-2.2 & $\begin{array}{l}\text { Adopt an ordinance requiring the installation of water efficient } \\
\text { plumbing fixtures for existing buildings when properties change } \\
\text { ownership/lessee. }\end{array}$ \\
\hline WC-4.3 & $\begin{array}{l}\text { Allow individual water customers to easily access their water use } \\
\text { information to encourage the installation of cost-effective water- } \\
\text { saving features and enable modified behavior to cut costs through } \\
\text { water use efficiency. }\end{array}$ \\
\hline
\end{tabular}




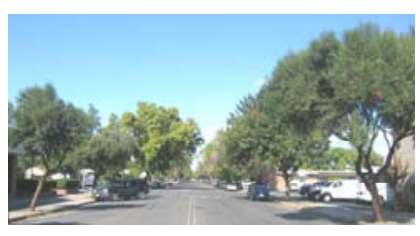

\section{INTRODUCTION}

Improving public health is directly related to one of the core tenets of sustainability: equity. Without a healthy environment and healthy residents, the quality of life for all Patterson residents will diminish. The Public Health chapter addresses air quality, climate change, food systems planning, and the promotion of physical fitness to reduce the obesity rate. Strategies such as increased transit, biking, and walking opportunities, included in Chapter I Land Use \& Transportation, serve to encourage physical fitness, thereby improving air quality and promoting public health. Green Building strategies (e.g. improving indoor air quality) are included in Chapter II - Energy. In other words, public health is implicitly addressed in many chapters.

Air quality is affected by several factors, including ozone and particulate matter (two of the six common air pollutants, US EPA), both of which are in large part related to emissions from buildings and from vehicles. According to the American Lung Association, breathing particle pollution diminishes lung function, increases the chance of heart attacks, cardiac arrhythmias, coughing, wheezing, cardiovascular disease (e.g. strokes and congestive heart failure), and increased severity of asthma attacks. Natural defenses help us to cough or sneeze larger particles out of our bodies, but this does not keep out smaller particles. Smaller particles get trapped in the lungs, and the smallest can even pass through the lung tissue into the blood stream, circulating like oxygen molecules. Regardless of size, particles can be harmful to one's health and very dangerous to breathe. Short-term exposure to particle pollution can even be deadly. Deaths can occur on the day that particle levels are high, or within one to two months. Infants and young children are especially vulnerable to increased mortality. Even young, healthy adults are at least prone to inflammation of lung tissue.

Public health can also be affected by climate change, in the form of longer, more intense and frequent heat waves resulting in more heat-related deaths and illness; storms; increased frequency of insect-borne illnesses as many insect ranges expand (e.g. malaria); and increased smog (US EPA). Climate change health effects are especially serious for youth, the elderly, and those with heart and respiratory problems. According to the US EPA, there is "virtual certainty" of declining air quality since greater heat can also worsen air pollution such as ozone or smog.

Climate change may also affect agriculture, impacting food and ultimately, public health. The supply and cost of food may be more costly in the future, as farmers and the food industry adapt to new climate patterns. A slight increase in temperature along with increasing $\mathrm{CO}_{2}$ levels may benefit some crops, although the impacts also depend on the availability of water and nutrients (US EPA 2009). For warming of more than a few degrees, the effects will become increasingly negative, especially for crops already toward the warm end of their natural range (US EPA 2009). 
An important aspect of public health is physical fitness. According to the advocates of the No Child Left Inside Act, one in three children in America are overweight or obese (Environmental Education and the No Child Left Behind Act). Young people are spending less time outdoors because recess periods are being shortened and children are spending more time inside after school and on the weekends. The City should encourage the Patterson Joint Unified School District (PJUSD) to spark children's interest in the outdoors and encourage participation in outside activities.

The following Opportunities and Constraints in Patterson should be addressed to improve sustainability:

\section{STRENGTHS \& OPPORTUNITIES}

1. The tree-lined main thoroughfares, abundance of parks, and agriculture help improve air quality

2. Given close proximity to agriculture and food processing operations, food centers have the ability to purchase fresh, healthy, organic food locally

3. City provides lots of parks, bicycle lanes, a community pool, a sports complex, and recreation programs

\section{CONSTRAINTS}

1. For 2009, Stanislaus County earned an ozone grade of "F" from the American Lung Association; between 2005-2007, there was an annual average of 45 Orange days (unhealthy for sensitive groups) and 2 Red days (unhealthy)

2. For 2009, Stanislaus County earned a grade of "F" from the American Lung Association, ranking $20^{\text {th }}$ for the most polluted county in the nation for short-term (24-hr) particle pollution; between 20052007, there was an annual average of 32 Orange days (unhealthy for sensitive groups) and 2 Red days (unhealthy)

3. Smog in the San Joaquin Valley is responsible for $\$ 3.2$ billion annually in health costs and asthma and other respiratory illnesses abound (LA Times March 2006) - which will worsen as temperatures rise with climate change

4. Lack of a Tree Master Plan

5. No higher education facilities, or an adult school; students commute 20 miles to Modesto Junior College

\section{RECOMMENDATIONS}

The City should work with Stanislaus County officials to promote the adoption of sustainable agriculture practices, community gardens, and the purchase of fresh, local, organic food options. When implemented, successful food systems planning will improve residents' health as well as the local economy, while decreasing the number of truck trips transporting food from thousands of miles away. By taking action to expand the urban forest (tree canopy) and decrease ozone and particulate matter levels, improved air quality will reduce the number of people who suffer from asthma, respiratory illnesses, and cancer.

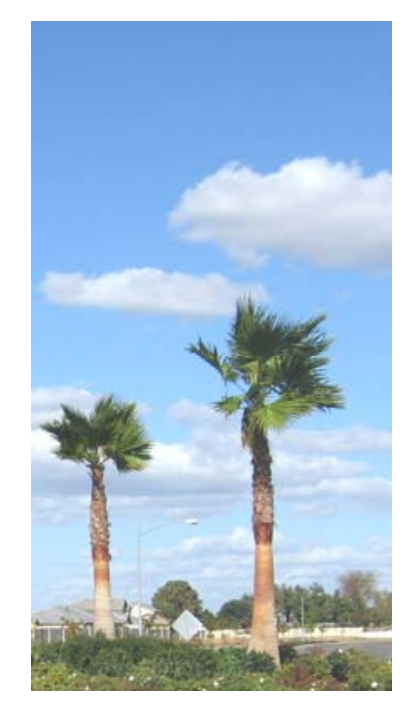


The following Goals and Actions seek to improve sustainability in Patterson:

\section{GOALS AND ACTIONS}

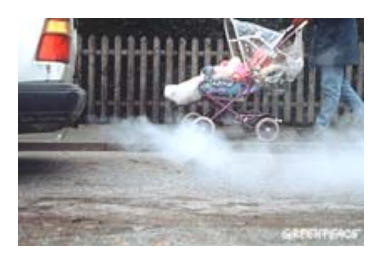

$\begin{array}{ll}\text { Goal PH-1: } & \begin{array}{l}\text { Reduce air pollution and greenhouse gas (GHG) } \\ \text { emissions. }\end{array}\end{array}$

\section{Actions}

PH-1.1 Collaborate with the San Joaquin Valley Air Pollution Control District, Stanislaus County, CARB, and others to reduce the air pollutant levels of ozone and particulate matter.

PH-1.2 Develop, adopt, and implement a Climate Action Plan (CAP) by 2012 .

a. Prepare a Greenhouse Gas Emissions Inventory for Patterson and adopt a Reduction Target by 2011.

b. Sign the U.S. Conference of Mayors Climate Protection Agreement.

c. Join the Cities for Climate Protection (CCP) Campaign under ICLEI - Local Governments for Sustainability.

d. Become a registered member of the California Climate Action Registry (CCAR).

PH-1.3 Adopt a Wood Smoke Ordinance to reduce the air quality impacts associated with smoke from non-EPA rated wood burning stoves and fireplaces. Require removal or replacement with a cleaner alternative.

PH-1.4 Adopt an ordinance restricting the use of gasoline-powered lawn mowers.

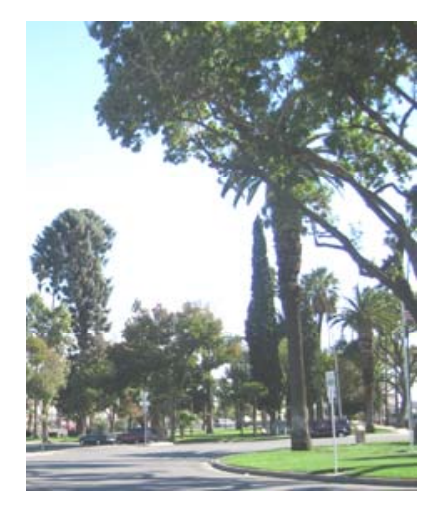

Goal PH-2: Establish and maintain a healthy urban forest.

\section{Actions}

PH-2.1 Develop, adopt, and implement a Tree Master Plan.

a. Include a Street Tree Plan for the downtown core and major arterial streets.

b. Prepare adequate maintenance plans for City-owned trees and landscaped medians.

c. Explore the feasibility of becoming a recognized Tree City USA.

PH-2.2 Adopt a Tree Preservation Ordinance to protect trees of a certain size or age. 
PH-2.3 Require submittal of a Parking Lot Tree Shading Tree Selection and Shading Plan for all new projects, to illustrate and explain how the project will plant and maintain trees to achieve shading of at least $50 \%$ of all paved parking and pedestrian surfaces, within 15 years of acquisition of a building permit.

PH-2.4 Compile a GIS-based database (tree inventory) of all Cityowned trees, including an assessment of the health and condition of the City's oldest and most significant trees.

PH-2.5 Implement a residential tree planting and replacement program with a goal of planting 100 new trees annually.

PH-2.6 Amend the approved drought-tolerant tree and plant list on the City website to include regionally-appropriate plants and trees with optimal carbon sequestration characteristics.

PH-2.7 Establish a municipal Tree Committee and support the establishment of a tree advocacy group, e.g. "Tree Patterson."

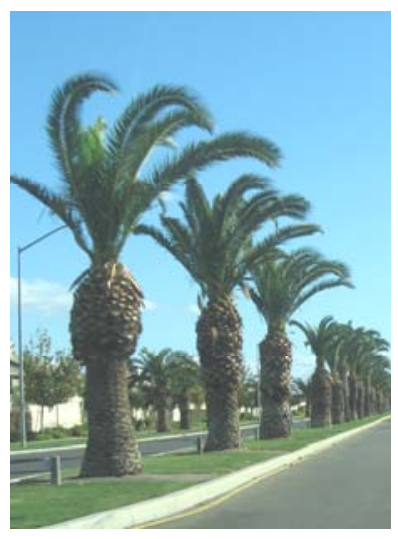

PH-2.8 Develop and adopt a program and seek grant funds for planting shade trees and other landscaping along all arterial streets and on all municipal property.

Goal PH-3: Improve the availability and access to local food sources.

\section{Actions}

PH-3.1 Collaborate with large manufacturers, food service operators, and grocers to adopt and implement a Food Systems Plan (local, sustainable food production, processing, distribution/purchasing, and composting food waste).

a. Remove obstacles and identify opportunities for piloting decentralized (local) food purchasing. Develop incentives for purchasing food produced within the region.

PH-3.2 Within or adjacent to community parks, designate land for community gardens.

PH-3.3 Amend Municipal Code to require new multi-family housing to provide a gardening space for tenants.

PH-3.4 As part of the Environmentally-Preferred Purchasing Policy (Action WR-2.2), require food vendors to provide a minimum of $20 \%$ locally grown organic food in orders received by the City (e.g. events). 


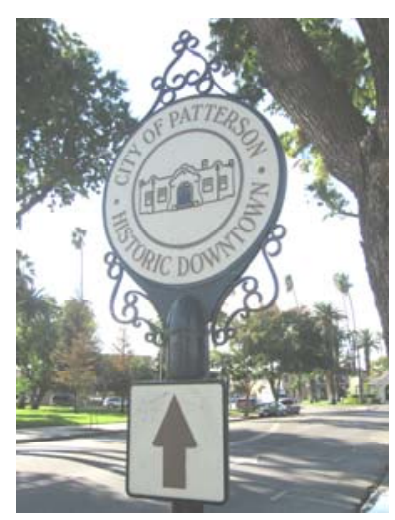

Goal PH-4: Educate the public about health issues related to air quality, eating habits, and physical fitness.

\section{Actions}

PH-4.1 At Farmer's Market, encourage residents to purchase produce from local farms and community-supported agriculture. Support similar projects to teach urban residents about the agricultural industry and to provide a forum for dialogue between urban residents and farmers.

PH-4.2 Collaborate with Stanislaus County to develop an outreach program encouraging local growers to adopt sustainable agriculture practices and organically farm their land.

PH-4.3 In the community newsletter and on the City website, inform the public of:

a. The social, economic, environmental, and health benefits of purchasing fresh, local, organic food products.

b. How to eat healthier by including organic food in a typical diet and how to read and understand nutrition labels. 


\section{MEASURING PROGRESS}

The following Sustainability Indicators will be monitored annually:

\section{AIR QUALITY}

1. Countywide ozone and particulate matter levels (measured by SJVAPCD)

a. Target: Downward trend

\section{URBAN FORESTRY}

2. Type and number of trees planted each year

a. Target: 100 new trees annually

\section{PHYSICAL HEALTH}

3. Percent of population overweight and obese by age and gender

a. Target: Decrease of $10 \%$ by 2015

4. Percent of fresh, locally-produced, organic produce served at City facilities and other institutions (e.g. schools, health facilities, and City-sponsored food programs)

a. Target: Upward trend 


\section{Public HeAlth}

\section{Mid-Term Phasing \& Implementation}

\begin{tabular}{|c|c|c|}
\hline No. & ACTION & RESPONSIBILITY \\
\hline $\mathrm{PH}-1.2$ & $\begin{array}{l}\text { Develop, adopt, and implement a Climate Action Plan (CAP) by } \\
\text { 2012. } \\
\text { a. Prepare a Greenhouse Gas Emissions Inventory for } \\
\text { Patterson and adopt a Reduction Target by } 2011 .\end{array}$ & $\begin{array}{l}\text { - City Council } \\
\text { - Community Development }\end{array}$ \\
\hline PH-1.3 & $\begin{array}{l}\text { Adopt a Wood Smoke Ordinance to reduce the air quality } \\
\text { impacts associated with smoke from non-EPA rated wood } \\
\text { burning stoves and fireplaces. Require removal or replacement } \\
\text { with a cleaner alternative. }\end{array}$ & - City Council \\
\hline PH-1.4 & $\begin{array}{l}\text { Adopt an ordinance restricting the use of gasoline-powered } \\
\text { lawn mowers. }\end{array}$ & - City Council \\
\hline PH-2.1 & Develop, adopt, and implement a Tree Master Plan. & $\begin{array}{l}\text { - } \text { Public Works } \\
\text { - } \text { Community Development }\end{array}$ \\
\hline $\mathrm{PH}-2.2$ & $\begin{array}{l}\text { Adopt a Tree Preservation Ordinance to protect trees of a } \\
\text { certain size or age. }\end{array}$ & $\begin{array}{ll}\text { - } & \text { City Council } \\
\text { - } & \text { Community Development }\end{array}$ \\
\hline PH-2.3 & $\begin{array}{l}\text { Amend Municipal Code to require submittal of a Parking Lot } \\
\text { Tree Shading Tree Selection and Shading Plan for all new } \\
\text { projects, to illustrate and explain how the project will plant and } \\
\text { maintain trees to achieve shading of at least } 50 \% \text { of all paved } \\
\text { parking and pedestrian surfaces, within } 15 \text { years of acquisition } \\
\text { of a building permit. }\end{array}$ & $\begin{array}{l}\text { - City Council } \\
\text { - Community Development }\end{array}$ \\
\hline PH-2.4 & $\begin{array}{l}\text { Compile a GIS-based database (tree inventory) of all City- } \\
\text { owned trees, including an assessment of the health and } \\
\text { condition of the City's oldest and most significant trees. }\end{array}$ & $\begin{array}{l}\text { - } \text { GIS Analyst } \\
\text { - Public Works }\end{array}$ \\
\hline PH-2.5 & $\begin{array}{l}\text { Implement a residential tree planting and replacement program } \\
\text { with a goal of planting } 100 \text { new trees annually. }\end{array}$ & - Public Works \\
\hline PH-2.6 & $\begin{array}{l}\text { Amend the approved drought-tolerant tree and plant list on the } \\
\text { City website to include regionally-appropriate plants and trees } \\
\text { with optimal carbon sequestration characteristics. }\end{array}$ & $\begin{array}{l}\text { - City Arborist } \\
\text { - Webmaster }\end{array}$ \\
\hline PH-3.1 & $\begin{array}{l}\text { Collaborate with large manufacturers, food service operators, } \\
\text { and grocers to adopt and implement a Food Systems Plan (local, } \\
\text { sustainable food production, processing, } \\
\text { distribution/purchasing, and composting food waste). } \\
\text { a. Remove obstacles and identify opportunities for piloting } \\
\text { decentralized (local) food purchasing. Develop incentives } \\
\text { for purchasing food produced within the region. }\end{array}$ & $\begin{array}{l}\text { - City Council } \\
\text { - Community Development }\end{array}$ \\
\hline $\mathrm{PH}-3.2$ & $\begin{array}{l}\text { Within or adjacent to community parks, designate land for } \\
\text { community gardens. }\end{array}$ & $\begin{array}{l}\text { - City Council } \\
\text { - Community Development }\end{array}$ \\
\hline
\end{tabular}




\section{SUSTAINABLE ECONOMIC DEVELOPMENT}

\section{INTRODUCTION}

Stanislaus County ranks as one of the nation's top ten agricultural counties, producing in excess of $\$ 1$ billion in gross farm income. The distinct advantage for sustainable economic development that Patterson shares is its proximity to major markets, access to major ports, easy access to major highways and railways, and prime location in the world's most highly productive farming region. For every dollar of agricultural production in Stanislaus County, $\$ 3.50$ in economic activity is generated through processing, packaging, marketing, and retail. Agriculture and food processing industries are important to the area's economic success, but the growing commercial, industrial, and service sectors will contribute to a diversified and sustainable economic base.

The following Opportunities and Constraints in Patterson should be addressed to improve sustainability:

\section{STRENGTHS \& OPPORTUNITIES}

1. Already-established Chamber of Commerce

2. Generally, residents' everyday basic needs are met locally, including basic necessities such as groceries and products typically found in a pharmacy

3. Agriculture, food processing, and distribution have long been active in the area

4. The Apricot Fiesta, an annual agricultural and community festival which began in 1970, is a great way to market local agriculture

\section{CONSTRAINTS}

1. Considerable "leakage" of local expenditures to other nearby cities such as Turlock or Modesto, for items such as clothing, electronics, and appliances

2. Lack of awareness in businesses about energy efficiency and water conservation, waste reduction, recycling, etc.

3. Conversion of productive farmland to urban development

\section{RECOMMENDATIONS}

There are several ways the City can strengthen its economy and maintain a diverse, stable economic base. By attracting goods \& services not currently found in Patterson, such as clothing, electronics, and appliances, the City can prevent leakage of sales tax revenue, while eliminating the need for residents to drive long distances for basic necessities, which also reduces greenhouse gas emissions. Through the preservation of agriculture and the re-establishment of a Farmers' Market, the City can help reinforce the viability of downtown. By creating a business-friendly regulatory environment for green companies, the City can attract renewable energy and clean technology firms, thereby improving the jobs/housing ratio. A Green 
Business Certification Program can serve as way to encourage local businesses to offer environmentally-friendly goods and services and make small changes, while still turning a profit. By employing minor, cost-effective improvements, commercial \& industrial businesses of all sizes, can have a powerful impact on the environment, employees, and consumers, while also cutting costs. Private

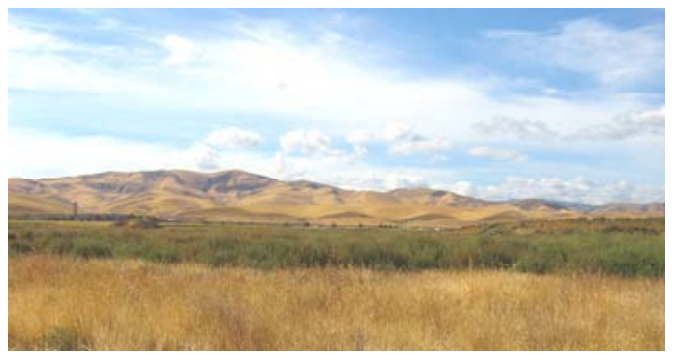
investment in solutions to improve sustainability can stimulate the economy through job creation, offer new marketing techniques, and create new business opportunities and partnerships, and ultimately serve as a model to residents. Energy efficiency and water conservation improvements, for example, save businesses money, increasing the amount of capital available for other ventures, such as research and development, or sponsoring local sports teams, scholarships, and community events.

The following Goals and Actions seek to improve economic sustainability in Patterson:

\section{GOALS AND ACTIONS}

Goal ED-l: Maintain a sustainable, diverse, and stable economy that supports the basic needs of all segments of the community.

\section{Actions}

ED-1.1 Establish a Green Business Certification Program.

a. Using the Bay Area Green Business program as a model, develop standards/criteria requiring for certification the adoption of sustainable business practices such as water conservation, energy conservation, solid waste reduction \& recycling, and pollution prevention.

b. Allow voluntary Green Business Certification before mandating it by ordinance for 2015 .

ED-1.2 Collaborate with the City's Economic Strategic Commission, the Chamber of Commerce, and the Stanislaus Economic Development Workforce and Alliance to promote the Green Business Certification Program.

ED-1.3 Prioritize the green sector in the City's overall economic development and workforce strategies (e.g. General Plan) by incorporating policies and incentives to attract new green businesses.

a. Establish and award bid preferences to City vendors and contractors that are certified Green Businesses. 
b. Establish a CleanTech Overlay Zone in the West Patterson Business Park industrial area, with "flex use" allowing research \& development, to attract new jobs in the renewable/clean energy technology sector.

ED-1.4 In the West Patterson Business Park, attract and retain a balance of different types of industrial uses.

ED-1.5 Re-establish and maintain a Farmers' Market to encourage residents and grocers to purchase produce from local farmers.

Goal ED-2: $\quad$ Increase public awareness of Green Businesses.

\section{Actions}

ED-2.1 Designate a City staff liaison to help create public/private partnerships and collaborate with the Chamber of Commerce to offer workshops informing companies about the Green Business Certification Program.

ED-2.2 Encourage copy centers, print shops, and other businesses to use soy-based ink and 100\% recycled paper (FSC-Certified 100\% Post-Consumer Waste Fiber).

ED-2.3 Offer an Outstanding Green Business Award to companies that exceed the minimum qualifications of the Green Business Certification Program.

ED-2.4 Establish a Greenest Restaurant Competition, Greenest Retail Store, Greenest Office, and Greenest Big Business (manufacturer, distributor, or large food outlet).

ED-2.5 Collaborate with major employers to increase their visibility by setting an example for the rest of the community incorporating energy efficiency, water conservation, waste reduction and recycling, renewable energy projects, etc.

ED-2.6 Collaborate with community-based organizations to develop workforce training programs to ensure that low and middleincome households develop the skills to obtain jobs in the green economy.

ED-2.7 In the community newsletter and on the City website, encourage residents to shop locally and explain the benefits, such as agricultural preservation (e.g. healthy food options, sustaining the local economy, carbon sequestration, decreased "Food Miles Traveled" which reduces greenhouse gas emissions).
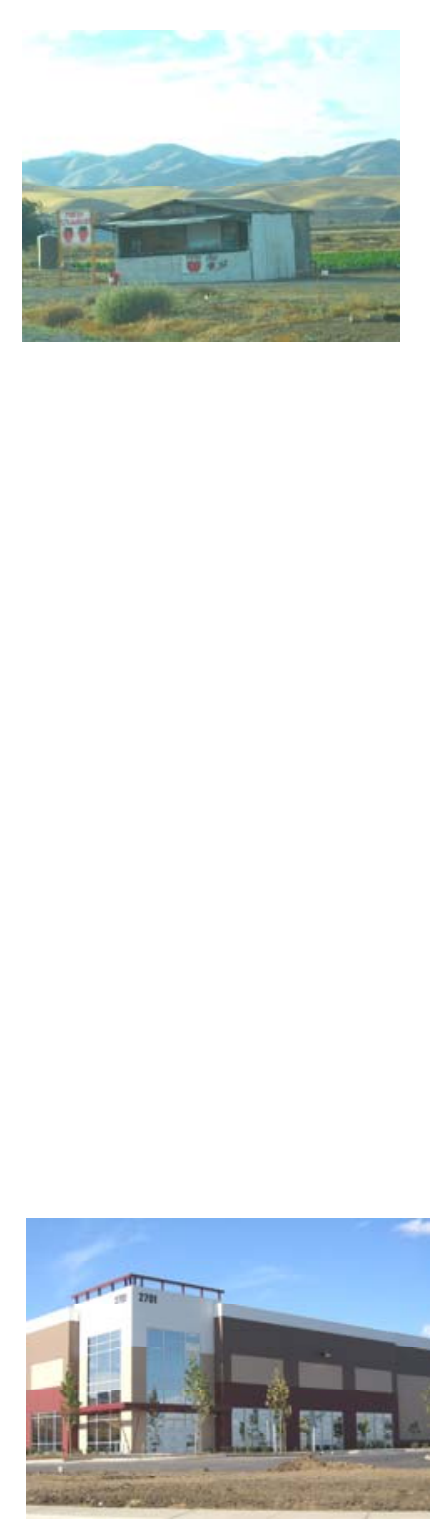


\section{MEASURING PROGRESS}

The following Sustainability Indicators will be monitored annually:

\section{GREEN BUSINESSES}

1. Number of certified "green" businesses

a. Target: 20 by 2012, and $100 \%$ of businesses by 2015

2. Percent of restaurants that purchase ingredients (e.g. produce) from local growers

a. Target: Upward trend

3. Percent of residents employed inside the City

a. Target: Upward trend

4. Percent of City employees who live inside the City

a. Target: $90 \%$ by 2015

\section{DIVERSE ECONOMIC BASE}

1. Jobs/housing ratio (number of jobs to the number of housing units)

b. Target: Ratio of l:1

2. Percentage of total economic activity/output (by sector)

a. Target: No single sector shall be greater than $25 \%$ of the total economic activity/output; and the top three sectors shall not be greater than $50 \%$ of the total economic activity/output. 


\section{Mid-Term Phasing \& Implementation}

\begin{tabular}{|c|c|c|}
\hline No. & ACTION & RESPONSIBILITY \\
\hline ED-1.1 & $\begin{array}{l}\text { Establish a Green Business Certification Program. } \\
\text { a. Using the Bay Area Green Business program as a model, } \\
\text { develop standards/criteria requiring for certification the } \\
\text { adoption of sustainable business practices such as water } \\
\text { conservation, energy conservation, solid waste reduction \& } \\
\text { recycling, and pollution prevention. }\end{array}$ & $\begin{array}{l}\text { - City Council } \\
\text { - Economic Strategic Commission } \\
\text { - Community Development }\end{array}$ \\
\hline ED-1.3 & $\begin{array}{l}\text { Prioritize the green sector in the City's overall economic } \\
\text { development and workforce strategies (e.g. General Plan) by } \\
\text { incorporating policies and incentives to attract new green } \\
\text { businesses. } \\
\text { a. Establish and award bid preferences to City vendors and } \\
\text { contractors that are certified Green Businesses. } \\
\text { b. Establish a CleanTech Overlay Zone in the West Patterson } \\
\text { Business Park industrial area, with "flex use" allowing } \\
\text { research \& development, to attract new jobs in the } \\
\text { renewable/clean energy technology sector. }\end{array}$ & $\begin{array}{l}\text { - City Council } \\
\text { - City Manager's Office } \\
\text { - Community Development }\end{array}$ \\
\hline ED-1.5 & $\begin{array}{l}\text { Re-establish and maintain a Farmers' Market to encourage } \\
\text { residents and grocers to purchase produce from local farmers. }\end{array}$ & - Community Development \\
\hline ED-2.3 & $\begin{array}{l}\text { Offer an Outstanding Green Business Award to companies that } \\
\text { exceed the minimum qualifications of the Green Business } \\
\text { Certification Program. }\end{array}$ & $\begin{array}{l}\text { - City Council } \\
\text { - Economic Strategic Commission }\end{array}$ \\
\hline ED-2.4 & $\begin{array}{l}\text { Establish a Greenest Restaurant Competition, Greenest Retail } \\
\text { Store, Greenest Office, and Greenest Big Business (manufacturer, } \\
\text { distributor, or large food outlet). }\end{array}$ & $\begin{array}{l}\text { - City Council } \\
\text { - Economic Strategic Commission }\end{array}$ \\
\hline
\end{tabular}




\section{OUTREACH \& AWARENESS}

\section{INTRODUCTION}

This chapter contains broad actions for community outreach to promote sustainability, while many other strategies are listed in their respective chapters based on sustainability focus area. This chapter does not repeat outreach measures from previous chapters. To improve sustainability, the City of Patterson should conduct outreach to educate and motivate the community to make small changes in their personal behavior. Public involvement is crucial to the implementation of this Plan. The actions of City employees, residents, and commercial and industrial businesses to help achieve sustainability will ultimately improve public health, safety, and welfare, as well as the quality of life in Patterson. Businesses and residents should have a basic understanding of the relationship between people and the environment, an understanding of key environmental challenges (environmental literacy), including global climate change and sustainability.

The following Opportunities and Constraints in Patterson should be addressed to improve sustainability:

\section{STRENGTHS \& OPPORTUNITIES}

1. City website displays water conservation methods, recommended efficient plumbing fixtures, recommended drought-tolerant and low water-use trees and plants, and the Landscaping Watering Schedule required by Municipal Code

2. Stanislaus Regional Transit (StaRT) bus schedules are available at City Hall

\section{CONSTRAINTS}

1. Lack of general public awareness of sustainability

\section{RECOMMENDATIONS}

The City should increase awareness of sustainability in the community to make people conscious of the link between their everyday actions (e.g. waste, energy/water use) and climate change. City staff should conduct an extensive outreach program by developing a variety of educational material that is understandable to the general public, made easily available on the City website and through other media, and tailored for target audiences (e.g. City employees, residents, Spanish-speaking residents, youth, commercial and industrial businesses). Outreach should inform people of the benefits of taking specific actions, how easy some measures are to improve sustainability, and how others are cost-effective and include a considerable return on investment. The City should first focus on encouraging people to reduce long distance commutes to work; walk, bicycle, and take transit; reduce energy use; conserve water; reduce waste and recycle more; shop locally; and eat healthy.

The following Goals and Actions seek to improve sustainability in Patterson: 


\section{GOALS AND ACTIONS}

Goal OA-1: Turn the City's employees into ambassadors for sustainability.

\section{Actions}

OA-1.1 Facilitate coordination among various City departments by forming, supporting, and maintaining an interagency working group (Green Team/Sustainability Task Force) to identify and implement immediate opportunities from this Plan (Departmental Action Plans) and develop a prioritized list of City actions based on this Plan and best practices elsewhere.

OA-1.2 Hire a Sustainability Coordinator who will promote, coordinate, and facilitate the Actions set forth in this Plan as well as all City sustainability projects.

OA-1.3 Develop staff training materials and conduct annual staff sustainability training.

OA-1.4 Provide sustainability training for Planning Commission, City Council, the Economic Strategic Commission, the Beautification Committee, and the Senior Center Board of Directors.

OA-1.5 The Finance Department will work with the Employees Retirement System to explore options for eco-friendly investing (in solutions).

Goal OA-2: Establish regional alliances to support the exchange of information and increase public awareness of sustainability.

\section{Actions}

OA-2.1 Join Green Cities California.

OA-2.2 Collaborate with StanCOG, Stanislaus County, the San Joaquin Valley Air Pollution Control District, the Great Valley Center, and the Westside Community Alliance to develop, share, and distribute education materials.

OA-2.3 Collaborate with local/regional educational institutions to develop and distribute outreach materials and make presentations to inform the public about sustainability (e.g. Modesto Junior College, CSU Stanislaus, and UC Merced). 
Never doubt that a group of thoughtful, committed citizens can change the world. Indeed, it's the only thing that ever has. Margaret Mead
Goal OA-3: Increase youth awareness of sustainability.

\section{Actions}

OA-3.1 Encourage Patterson Joint Unified School District (PJUSD) to partner with school districts throughout Stanislaus County to hold a Green Science \& Technology Fair. Encourage local green certified businesses to sponsor an Invention Convention as part of this event meant to educate and excite youth about sustainability.

OA-3.2 Collaborate with the Delta Sierra CREEC Environmental Education Network (California Regional Environmental Education Community, Region 6B STEEP: Stanislaus and Tuolumne Counties) and the Stanislaus County Office of Education to develop and distribute education materials to students, make presentations at schools, and hold awareness events.

OA-3.3 Support Environmental Education and the proposed No Child Left Inside Act (as part of the No Child Left Behind Act) to raise awareness of behavioral problems brought on by Nature Deficit Disorder (Richard Louv, 2005 Last Child in the Woods) and rises in childhood obesity and attention disorders.

OA-3.4 Encourage Patterson Joint Unified School District (PJUSD) to take part in the National Environmental Education Week, and the National Take a Child Outside Week to help children gain a better understanding and appreciation for the environment.

OA-3.5 Encourage Patterson Joint Unified School District (PJUSD) to integrate sustainability and environmental literacy into the academic curriculum. Actively support the California EEI Curriculum (Education and the Environment Initiative).

Goal OA-4: Increase public awareness of measures to improve sustainability.

\section{Actions}

OA-4.1 Review this Sustainability Plan annually in an Annual Progress Report made available to the public and presented to City Council beginning in 2010. Measure successful implementation, evaluate progress, and update Actions, Progress Indicators, and priorities.

OA-4.2 Establish, update, and maintain a Sustainability webpage on the City website. 
a. Offer educational resources, "Tips to be Sustainable," information about City sustainability programs, past accomplishments, and a link to a specialized calculator to determine a personal (or household) ecological footprint.

b. Develop and implement an information exchange program (e.g. blog) made available through the City Website for sharing ideas, experiences, best practices, and success stories.

c. Develop and implement a technical assistance program where residents and businesses are able to request direct technical support and individualized help from an expert/specialist (e.g. energy/water/waste audit, commute trip reduction).

OA-4.3 Host an annual event with the Mayor and other civic leaders on Earth Day to recognize and celebrate past accomplishments improving sustainability, announce "Next Steps," and recruit partners from the business community.

OA-4.4 Set up a booth to promote sustainability at events including school fairs, health fairs, the annual Apricot Fiesta, Fall Family Festival \& Pride Fun Run, the Art and Wine Gala, Holiday Parade, and other City-sponsored events.

OA-4.5 Install flags on lightpoles throughout the City promoting the City's 12 new "Theme Months," each focusing on a different

You must be the change you want to see in the world. - Gandhi aspect of sustainability. Offer one-time workshops and a lecture series based on the Sustainability Themes throughout the year.

- January: Waste Reduction \& Recycling Month

- February: Transit Month

- Bus/Walk to Work Week

- March: Energy Efficiency Month

- April: Water Conservation Month

- May: Bike Month

- June: Green Building Month

- July: Solar Energy Month

- Install rooftop solar panels!

- August: Local Food Month

- Eat Organic!

- September: Urban Forestry Month

- Plant a Tree!

- October: Green Business Month

- November: Air Quality Month

- Replace your wood fireplace with a clean alternative!

- December: Eco-Friendly Purchasing Month

OA-4.6 Develop catch phrases and slogans, for use in the community newsletter, on the City website, and other marketing methods, to garner public attention for new outreach programs. 
OA-4.7 Form a Citizen Advisory Committee to work with the City's interagency working group (Green Team/Sustainability Task Force), oversee, and provide input for the implementation of this Sustainability Plan.

OA-4.8 Establish a Center for Sustainability resource center at the Patterson Branch Library.

OA-4.9 Partner with public agencies, a variety of media (e.g. Community Newsletter, Patterson Irrigator Newspaper, and local television news stations), community groups (e.g. nonprofits, churches), educational groups, and other interested parties to promote what actions the City is taking and what actions residents can take. 


\section{MEAsuring Progress}

The following Sustainability Indicators will be monitored annually:

\section{OUTREACH $\&$ AWARENESS}

1. Number of website hits and technical assistance requests

a. Target: Upward trend

2. Number of participants trained (City staff, private contractors, citizens)

a. Target: Upward trend

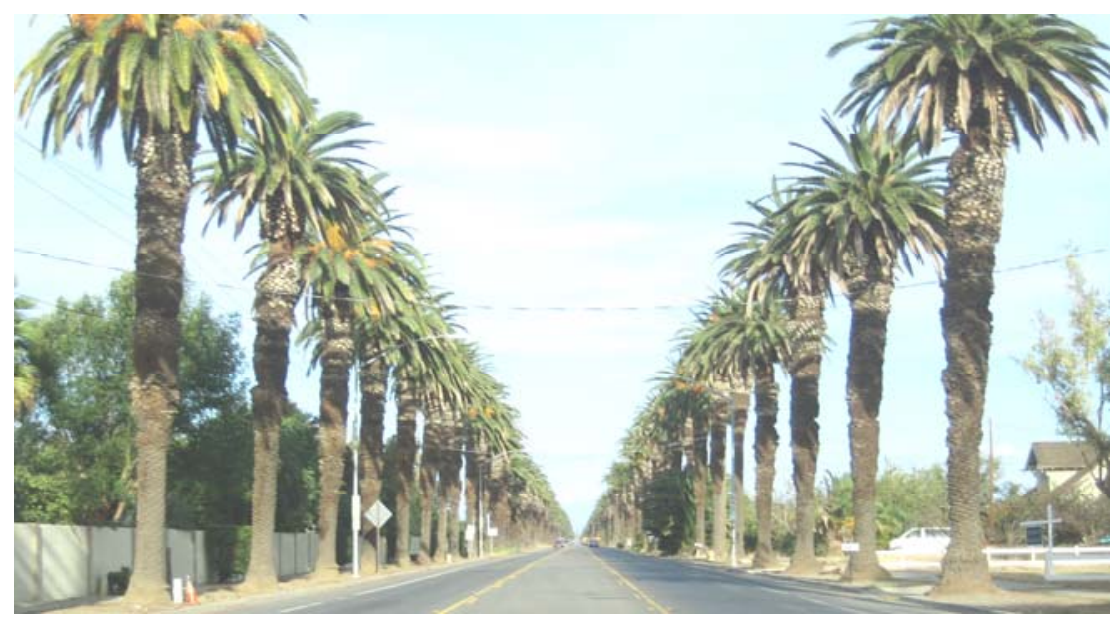




\section{Mid-Term Phasing \& Implementation}

\begin{tabular}{|c|c|c|}
\hline No. & ACTION & RESPONSIBILITY \\
\hline OA-1.1 & $\begin{array}{l}\text { Facilitate coordination among various City departments by } \\
\text { forming, supporting, and maintaining an interagency working } \\
\text { group (Green Team/Sustainability Task Force) to identify } \\
\text { and implement immediate opportunities from this Plan } \\
\text { (Departmental Action Plans) and develop a prioritized list of } \\
\text { City actions based on this Plan and best practices elsewhere. }\end{array}$ & $\begin{array}{l}\text { City Council } \\
\text { Community Development }\end{array}$ \\
\hline OA-1.2 & $\begin{array}{l}\text { Hire a Sustainability Coordinator who will promote, } \\
\text { coordinate, and facilitate the Actions set forth in this Plan as } \\
\text { well as all City sustainability projects. }\end{array}$ & City Council \\
\hline OA-3.1 & $\begin{array}{l}\text { Encourage Patterson Joint Unified School District (PJUSD) } \\
\text { to partner with school districts throughout Stanislaus } \\
\text { County to hold a Green Science \& Technology Fair. } \\
\text { Encourage local green certified businesses to sponsor an } \\
\text { Invention Convention as part of this event meant to educate } \\
\text { and excite youth about sustainability. }\end{array}$ & Community Development \\
\hline $\mathrm{OA}-4.1$ & $\begin{array}{l}\text { Review this Sustainability Plan annually in an Annual } \\
\text { Progress Report made available to the public and presented } \\
\text { to City Council beginning in 2010. Measure successful } \\
\text { implementation, evaluate progress, and update Actions, } \\
\text { Progress Indicators, and priorities. }\end{array}$ & $\begin{array}{l}\text { City Council } \\
\text { Community Development }\end{array}$ \\
\hline $\mathrm{OA}-4.2$ & $\begin{array}{l}\text { Establish, update, and maintain a Sustainability webpage on } \\
\text { the City website. }\end{array}$ & Webmaster \\
\hline $\mathrm{OA}-4.3$ & $\begin{array}{l}\text { Host an annual event with the Mayor and other civic leaders } \\
\text { on Earth Day to recognize and celebrate past } \\
\text { accomplishments improving sustainability, announce "Next } \\
\text { Steps," and recruit partners from the business community. }\end{array}$ & $\begin{array}{l}\text { Mayor } \\
\text { City Council } \\
\text { Community Development }\end{array}$ \\
\hline $\mathrm{OA}-4.4$ & $\begin{array}{l}\text { Set up a booth to promote sustainability at events including } \\
\text { school fairs, health fairs, the annual Apricot Fiesta, Fall } \\
\text { Family Festival \& Pride Fun Run, the Art and Wine Gala, } \\
\text { Holiday Parade, and other City-sponsored events. }\end{array}$ & $\begin{array}{l}\text { Volunteers/Interns } \\
\text { Community Development }\end{array}$ \\
\hline $\mathrm{OA}-4.7$ & $\begin{array}{l}\text { Form a Citizen Advisory Committee to work with the City's } \\
\text { interagency working group (Green Team/Sustainability Task } \\
\text { Force), oversee, and provide input for the implementation of } \\
\text { this Sustainability Plan. }\end{array}$ & City Council \\
\hline
\end{tabular}


PHASING, IMPLEMENTATION \& FUNDING

\section{PHASING \& IMPLEMENTATION}

This Sustainability Plan is meant to be a working strategy document that will continue to evolve. It will be reviewed on an annual basis. The Annual Progress Report will measure successful implementation, evaluate progress, and update Actions and priorities due to knowledge of new best practices and performance indicators brought on by improved technology, availability of funding, or other factors. The City will establish an interdepartmental working group (Green Team) and an external advisory group to secure funding sources and help implement the Plan.

The City should first focus primarily on City operations to lead by example. Actions that have low cost, or no cost, can be implemented immediately with existing resources. Actions for the City, its residents, and private businesses should be economically feasible to the greatest extent possible. Partnerships and local community involvement will be crucial to the success of this Plan. Achieving sustainability will require the City's leadership, and participation by residents and businesses. The most cost-effective Actions will be selected for Near-Term implementation based on an analysis of the associated costs and benefits (financial, environmental, and social), with an emphasis on investing in Actions delivering multiple benefits (e.g. cost savings, improved quality of air and water).

The Mid-Term Phasing \& Implementation table following each chapter, or Sustainability Focus Area, shows Actions recommended for implementation within ten years of plan adoption. Actions have been prioritized based on the degree that the City has the ability to influence implementation, the degree to which they promote long-term community and environmental sustainability, and the extent that residents will benefit in terms of costsavings and improved quality of life and public health. Additional Actions for Consideration are included in Appendix C. Some Actions have been temporarily excluded for a variety of reasons, some because of funding scarcity, some because they are outside the City's authority, and others because they should be considered for later implementation. The Additional Actions for Consideration should be analyzed as part of the evaluation process that goes into the Annual Progress Report. When new funding sources are made available, or City staff time becomes more readily available, these Additional Actions for Consideration should be considered for inclusion in the Sustainability Plan.

The following Near-Term Phasing table lists the Actions intended for implementation within five years of plan adoption: 


\section{Near-Term Phasing \& Implementation}

\begin{tabular}{|c|c|c|}
\hline No. & ACTION & RESPONSIBILITY \\
\hline LT-4.2 & $\begin{array}{l}\text { Amend Municipal Code to encourage parking in the rear of } \\
\text { buildings. Design residential development to be neighborhood } \\
\text { villages with parking separate from homes and a network of } \\
\text { pathways for pedestrians and bicyclists to encourage physical } \\
\text { fitness and increase social interaction. }\end{array}$ & Community Development \\
\hline LT-5.1 & $\begin{array}{l}\text { Develop and adopt a Bicycle \& Pedestrian Plan by } 2011 \text { to replace } \\
\text { the existing Bicycle Master Plan and plan for the necessary } \\
\text { requirements to achieve recognition as a Bicycle Friendly } \\
\text { Community under the League of American Bicyclists. } \\
\text { a. Identify and prioritize bicycle \& } \begin{array}{l}\text { improvement projects. } \\
\text { b. Maintenance plan for bicycle and pedestrian } \\
\text { infrastructure. }\end{array}\end{array}$ & Community Development \\
\hline LT-9.1 & $\begin{array}{l}\text { By 2014, develop City infrastructure to support plug-in hybrid and } \\
\text { electric vehicle charging stations. }\end{array}$ & Community Development \\
\hline LT-11.5 & $\begin{array}{l}\text { Develop an easy-to-use, web-based ride-matching service for } \\
\text { residents, made available on the City website. }\end{array}$ & Webmaster \\
\hline LT-11.6 & $\begin{array}{l}\text { Develop events around, and participate in, National Bike Month } \\
\text { (May) and Bike-to-Work Week (counting cyclists), promoted by } \\
\text { the League of American Bicyclists. }\end{array}$ & Community Development \\
\hline EE-1.1 & $\begin{array}{l}\text { By 2010, adopt a mandatory Green Building Ordinance for new } \\
\text { construction and renovation. }\end{array}$ & $\begin{array}{l}\text { City Council } \\
\text { Community Development }\end{array}$ \\
\hline EE-2.4 & $\begin{array}{l}\text { Conduct individualized Energy Audits of all City-owned facilities } \\
\text { by } 2010 \text { and implement cost-effective retrofits by } 2011 \text {. }\end{array}$ & Public Works \\
\hline EE-3.1 & $\begin{array}{l}\text { Offer inexpensive individualized Energy Audits for residential and } \\
\text { commercial \& industrial buildings, educating occupants on cost- } \\
\text { effective retrofits. }\end{array}$ & Public Works \\
\hline EE-4.2 & $\begin{array}{l}\text { Amend Municipal Code to streamline the approval of solar panels } \\
\text { and small-scale wind turbines. Protect light access for solar energy } \\
\text { systems. }\end{array}$ & $\begin{array}{l}\text { City Council } \\
\text { Community Development }\end{array}$ \\
\hline $\mathrm{EE}-4.5$ & $\begin{array}{l}\text { Encourage installation and private funding of on-site renewable } \\
\text { energy projects in Patterson, e.g. homes; roofs and parking lot solar } \\
\text { photovoltaic arrays in the West Patterson Business Park and in } \\
\text { commercial centers providing a large area for solar panels, and } \\
\text { providing shade for vehicles. }\end{array}$ & Community Development \\
\hline EE-5.1.a & $\begin{array}{l}\text { Provide LEED and GreenPoint Rated (GPR) training for two key } \\
\text { Planning \& Building staff to offer consulting services (for a fee) to } \\
\text { applicants. }\end{array}$ & Community Development \\
\hline $\mathrm{EE}-5.2$ & $\begin{array}{l}\text { Install demonstration projects (e.g. solar) at City facilities and } \\
\text { schools to serve as educational displays with permanent } \\
\text { interpretive panels that teach about the building's use of green } \\
\text { technology. }\end{array}$ & $\begin{array}{l}\text { Public Works } \\
\text { Community Development }\end{array}$ \\
\hline WR-1.1 & $\begin{array}{l}\text { Adopt a mandatory Construction \& Demolition (C\&D) } \\
\text { Ordinance, as part of the Green Building Ordinance (Action EE- } \\
\text { 1.1), requiring all new development projects to submit a plan to } \\
\text { recycle a minimum of } 60 \% \text { of construction and demolition waste. }\end{array}$ & $\begin{array}{l}\text { City Council } \\
\text { Community Development }\end{array}$ \\
\hline WR-1.2 & $\begin{array}{l}\text { In partnership with local businesses, impose a } 25 \text {-cent fee on paper } \\
\text { and plastic shopping bags at grocery, drug, and convenience } \\
\text { stores. Impose a ban for } 2012 \text {. }\end{array}$ & $\begin{array}{l}\text { City Council } \\
\text { Community Development }\end{array}$ \\
\hline WR-1.3 & $\begin{array}{l}\text { Adopt an ordinance banning foam containers (e.g. plates, meat } \\
\text { trays, egg cartons, and hot \& cold beverage cups), disposable } \\
\text { plastic or plastic-coated paper products, and non-recyclable } \\
\text { materials in restaurants, food centers, and retail stores. Encourage } \\
\text { food service industry (restaurants, delicatessens, fast food outlets, }\end{array}$ & $\begin{array}{l}\text { City Council } \\
\text { Community Development }\end{array}$ \\
\hline
\end{tabular}




\section{Near-Term Phasing \& Implementation}

\begin{tabular}{|c|c|c|}
\hline & $\begin{array}{l}\text { coffee shops, and grocery stores) to convert to packaging that is } \\
\text { biodegradable (compostable) or locally recyclable. Adopt an } \\
\text { ordinance making it mandatory for } 2012 \text {. }\end{array}$ & \\
\hline WR-2.1 & $\begin{array}{l}\text { On the City website, allow residents to securely view statements } \\
\text { and pay online for business licenses, permits, parking citations, } \\
\text { and utility services: water, sewer, refuse. }\end{array}$ & Webmaster \\
\hline WR-2.2 & $\begin{array}{l}\text { Develop an Environmentally-Preferred Purchasing Policy for the } \\
\text { City to integrate waste reduction solutions into purchasing and } \\
\text { investment decisions, and decrease consumption of non-local, non- } \\
\text { renewable, and non-recyclable materials. } \\
\text { a. Ban the use of City funds to purchase single-serving plastic } \\
\text { bottled water. }\end{array}$ & $\begin{array}{l}\text { City Council } \\
\text { City Manager's Office } \\
\text { Community Development }\end{array}$ \\
\hline WR-4.4 & Establish Outstanding Recycler Awards for businesses. & City Council \\
\hline WC-1.1 & $\begin{array}{l}\text { City staff (Water Conservation Control) will conduct } \\
\text { individualized Water Audits (inspection program performed } \\
\text { simultaneously with Energy Audits). }\end{array}$ & Public Works \\
\hline WC-2.1 & $\begin{array}{l}\text { Adopt a usage-based fee system (tiered rate structure) to } \\
\text { encourage efficient residential and commercial } \& \text { industrial water } \\
\text { use. Customers will be awarded a lower cost for consuming less, } \\
\text { with increasing cost as consumption increases, and will pay a } \\
\text { penalty fee when exceeding a certain amount of water usage. }\end{array}$ & $\begin{array}{l}\text { City Council } \\
\text { Public Works }\end{array}$ \\
\hline WC-2.2 & $\begin{array}{l}\text { Adopt an ordinance requiring the installation of water efficient } \\
\text { plumbing fixtures for existing buildings when properties change } \\
\text { ownership/lessee. }\end{array}$ & $\begin{array}{l}\text { City Council } \\
\text { Community Development }\end{array}$ \\
\hline PH-1.2 & $\begin{array}{l}\text { Develop, adopt, and implement a Climate Action Plan (CAP) by } \\
\text { 2012. } \\
\text { a. Prepare a Greenhouse Gas Emissions Inventory for Patterson } \\
\text { and adopt a Reduction Target by } 2011 \text {. }\end{array}$ & $\begin{array}{l}\text { City Council } \\
\text { Community Development }\end{array}$ \\
\hline PH-1.3 & $\begin{array}{l}\text { Adopt a Wood Smoke Ordinance to reduce the air quality impacts } \\
\text { associated with smoke from non-EPA rated wood burning stoves } \\
\text { and fireplaces. Require removal or replacement with a cleaner } \\
\text { alternative. }\end{array}$ & City Council \\
\hline PH-2.1 & Develop, adopt, and implement a Tree Master Plan. & $\begin{array}{l}\text { Public Works } \\
\text { Community Development }\end{array}$ \\
\hline PH-2.2 & $\begin{array}{l}\text { Adopt a Tree Preservation Ordinance to protect trees of a certain } \\
\text { size or age. }\end{array}$ & $\begin{array}{l}\text { City Council } \\
\text { Community Development }\end{array}$ \\
\hline PH-2.3 & $\begin{array}{l}\text { Amend Municipal Code to require submittal of a Parking Lot Tree } \\
\text { Shading Tree Selection and Shading Plan for all new projects, to } \\
\text { illustrate and explain how the project will plant and maintain } \\
\text { trees to achieve shading of at least } 50 \% \text { of all paved parking and } \\
\text { pedestrian surfaces, within } 15 \text { years of acquisition of a building } \\
\text { permit. }\end{array}$ & $\begin{array}{l}\text { City Council } \\
\text { Community Development }\end{array}$ \\
\hline PH-2.4 & $\begin{array}{l}\text { Compile a GIS-based database (tree inventory) of all City-owned } \\
\text { trees, including an assessment of the health and condition of the } \\
\text { City's oldest and most significant trees. }\end{array}$ & $\begin{array}{l}\text { GIS Analyst } \\
\text { Public Works }\end{array}$ \\
\hline PH-2.5 & $\begin{array}{l}\text { Implement a residential tree planting and replacement program } \\
\text { with a goal of planting } 100 \text { new trees annually. }\end{array}$ & Public Works \\
\hline PH-2.6 & $\begin{array}{l}\text { Amend the approved drought-tolerant tree and plant list on the } \\
\text { City website to include regionally-appropriate plants and trees } \\
\text { with optimal carbon sequestration characteristics. }\end{array}$ & $\begin{array}{l}\text { City Arborist } \\
\text { Webmaster }\end{array}$ \\
\hline PH-3.2 & $\begin{array}{l}\text { Within or adjacent to community parks, designate land for } \\
\text { community gardens. }\end{array}$ & $\begin{array}{l}\text { City Council } \\
\text { Community Development }\end{array}$ \\
\hline ED-1.1 & $\begin{array}{l}\text { Establish a Green Business Certification Program. } \\
\text { a. Using the Bay Area Green Business program as a model, } \\
\text { develop standards/criteria requiring for certification the } \\
\text { adoption of sustainable business practices such as water }\end{array}$ & $\begin{array}{l}\text { City Council } \\
\text { Economic Strategic Commission } \\
\text { Community Development }\end{array}$ \\
\hline
\end{tabular}




\section{Near-Term Phasing \& Implementation}

\begin{tabular}{|c|c|c|}
\hline & $\begin{array}{l}\text { conservation, energy conservation, solid waste reduction } \& \\
\text { recycling, and pollution prevention. }\end{array}$ & \\
\hline ED-1.3 & $\begin{array}{l}\text { Prioritize the green sector in the City's overall economic } \\
\text { development and workforce strategies (e.g. General Plan) by } \\
\text { incorporating policies and incentives to attract new green } \\
\text { businesses. } \\
\text { a. Establish and award bid preferences to City vendors and } \\
\text { contractors that are certified Green Businesses. } \\
\text { b. Establish a CleanTech Overlay Zone in the West Patterson } \\
\text { Business Park industrial area, with "flex use" allowing } \\
\text { research \& development, to attract new jobs in the } \\
\text { renewable/clean energy technology sector. }\end{array}$ & $\begin{array}{l}\text { City Council } \\
\text { City Manager's Office } \\
\text { Community Development }\end{array}$ \\
\hline ED-1.5 & $\begin{array}{l}\text { Re-establish and maintain a Farmers' Market to encourage } \\
\text { residents and grocers to purchase produce from local farmers. }\end{array}$ & Community Development \\
\hline ED-2.3 & $\begin{array}{l}\text { Offer an Outstanding Green Business Award to companies that } \\
\text { exceed the minimum qualifications of the Green Business } \\
\text { Certification Program. }\end{array}$ & $\begin{array}{l}\text { City Council } \\
\text { Economic Strategic Commission }\end{array}$ \\
\hline OA-1.1 & $\begin{array}{l}\text { Facilitate coordination among various City departments by } \\
\text { forming, supporting, and maintaining an interagency working } \\
\text { group (Green Team/Sustainability Task Force) to identify and } \\
\text { implement immediate opportunities from this Plan (Departmental } \\
\text { Action Plans) and develop a prioritized list of City actions based } \\
\text { on this Plan and best practices elsewhere. }\end{array}$ & $\begin{array}{l}\text { City Council } \\
\text { Community Development }\end{array}$ \\
\hline OA-1.2 & $\begin{array}{l}\text { Hire a Sustainability Coordinator who will promote, coordinate, } \\
\text { and facilitate the Actions set forth in this Plan as well as all City } \\
\text { sustainability projects. }\end{array}$ & City Council \\
\hline $\mathrm{OA}-4.1$ & $\begin{array}{l}\text { Review this Sustainability Plan annually in an Annual Progress } \\
\text { Report made available to the public and presented to City Council } \\
\text { beginning in 2010. Measure successful implementation, evaluate } \\
\text { progress, and update Actions, Progress Indicators, and priorities. }\end{array}$ & $\begin{array}{l}\text { City Council } \\
\text { Community Development }\end{array}$ \\
\hline $\mathrm{OA}-4.2$ & $\begin{array}{l}\text { Establish, update, and maintain a Sustainability webpage on the } \\
\text { City website. }\end{array}$ & Webmaster \\
\hline $\mathrm{OA}-4.3$ & $\begin{array}{l}\text { Host an annual event with the Mayor and other civic leaders on } \\
\text { Earth Day to recognize and celebrate past accomplishments } \\
\text { improving sustainability, announce "Next Steps," and recruit } \\
\text { partners from the business community. }\end{array}$ & $\begin{array}{l}\text { Mayor } \\
\text { City Council } \\
\text { Community Development }\end{array}$ \\
\hline $\mathrm{OA}-4.4$ & $\begin{array}{l}\text { Set up a booth to promote sustainability at events including school } \\
\text { fairs, health fairs, the annual Apricot Fiesta, Fall Family Festival \& } \\
\text { Pride Fun Run, the Art and Wine Gala, Holiday Parade, and other } \\
\text { City-sponsored events. }\end{array}$ & $\begin{array}{l}\text { Volunteers/Interns } \\
\text { Community Development }\end{array}$ \\
\hline $\mathrm{OA}-4.7$ & $\begin{array}{l}\text { Form a Citizen Advisory Committee to work with the City's } \\
\text { interagency working group (Green Team/Sustainability Task } \\
\text { Force), oversee, and provide input for the implementation of this } \\
\text { Sustainability Plan. }\end{array}$ & City Council \\
\hline
\end{tabular}




\section{FUNDING}

This section presents options for funding the various Actions recommended in this Sustainability Plan. Although the discussion is aimed primarily at actions to be undertaken directly by the City, many of the potential funding options are applicable to other agencies, private households, businesses and organizations. The list of funding sources is not exhaustive, recognizing that these sources will change over time. Accordingly, the City should remain vigilant and take advantage of funding opportunities when they arise.

\section{FEDERAL FUNDING}

The American Recovery and Reinvestment Act. In February 2009, President Obama signed the American Recovery and Reinvestment Act (AARA), also known as the federal stimulus, a $\$ 787$ billion plan to create jobs, help revive the economy, and make significant improvements to the nation's infrastructure. More than $\$ 80$ billion of monies provided in the Act will benefit California.

Additionally, Californians will receive an estimated $\$ 35.4$ Billion in tax breaks aimed at the following:

- Revive the renewable energy industry and provide the capital over the next three years to eventually double domestic renewable energy capacity;

- Undertake the largest weatherization program in history by modernizing 75 percent of federal building space and more than one million homes;

- As part of the $\$ 150$ billion investment in new infrastructure, enact the largest increase in funding of our nation's roads, bridges, and mass transit systems since the creation of the national highway system in the 1950s. http://www.recovery.ca.gov/

Of the $\$ 80$ billion available to California, the following amounts have been allocated for energy-and climate-related programs and initiatives:

- $\$ 3.1$ billion for the State Energy Program

- $\$ 3.2$ billion for Energy Efficiency and Conservation Block Grants

- $\$ 5$ billion for the Weatherization Assistance Program

- $\$ 400$ million for transportation electrification

- \$300 million for Energy Efficient Appliance Rebate Program and ENERGY STAR ${ }^{\circledR}$

- $\$ 300$ million for Alternative Fueled-Vehicles Pilot Grant Program

- $\$ 300$ million for diesel conversions

- \$500-\$750 million for workforce assistance

- $\$ 2.5$ billion for applied research, development, demonstration and deployment including:

o $\$ 800$ million for biomass

o $\$ 400$ million for geothermal 
o $\$ 50$ million for information and communications technology

- $\$ 2$ billion for advanced battery manufacturing grant

- $\$ 4.5$ billion for smart grid \& meter

- $\$ 1.6$ billion for clean renewable energy bonds

- $\$ 2.4$ billion for qualified energy conservation bonds

- $\$ 1.4$ billion for green infrastructure

- $\$ 2.75$ billion for green housing

- Energy-related tax incentives

http://www.icleiusa.org/action-center/financing-staffing/overview-ofstimulus-funded-programs-and-initiatives

These funds are administered through the following federal funding programs:

- Energy Efficiency and Conservation Block Grants

- State Energy Program

- Weatherization Assistance Program

- Alternative Fueled Vehicles Pilot Grant Program (Clean Cities Program, Department of Energy)

- EPA Diesel Emission Reduction Act Grants

- Transportation Electrification

- Green Jobs Training

- Clean Water and River Restoration Funding

http://www.icleiusa.org/action-center/financing-staffing/additionalstimulus-funded-opportunities

Clean Water State Revolving Fund Program (CWSRF) has provided more than $\$ 5$ billion annually in recent years to fund (low-interest loans) water quality protection projects for wastewater treatment, nonpoint source pollution control, and watershed management. The program also has partnerships with banks, nonprofits, local governments, and other federal and state agencies to aid in securing other funding sources.

http://www.epa.gov/owm/cwfinance/cwsrf/

Clean Cities Program (US Department of Energy) offers Financing Opportunities, under the Office of Energy Efficiency and Renewable Energy. http://wwwl.eere.energy.gov/cleancities/financial opps.html

Federal Incentives/Policies for Renewables \& Efficiency is a database of funding options available for energy efficiency and renewable energy projects. http://www.dsireusa.org/incentives/index.cfm?state=us\&re=1\&EE=1

Energy and Environmental Conservation Block Grant (EECBG) through the US Department of Energy and California Energy Commission - over $\$ 355$ Million in funding to be used for http://www.eecbg.energy.gov/

Energy Star (US EPA, Department of Energy) offers Federal Tax Credits for Energy Efficiency, for new and existing structures (residential \& commercial) and appliances.

http://www.energystar.gov/index.cfm?c=products.pr tax credits 
Environmental Education Grants Program (US EPA Environmental Education Division, Office of Children's Health Protection and Environmental Education) supports environmental education projects that enhance public awareness to help people make informed decisions that affect environmental quality. Annual funding for the program ranges between $\$ 2$ and $\$ 3$ million. Most grants are in the $\$ 15,000$ to $\$ 25,000$ range. http://www.epa.gov/Education/grants.html

Federal Transit Administration Grants \& Financing (Department of Transportation) supports public transportation by issuing grants for planning, vehicle purchases, facility construction, operations, and other purposes. FTA administers this financial assistance according to the Safe, Accountable, Flexible, and Efficient Transportation Equity Act: A Legacy for Users (August 2005). The SAFETEA-LU CMAQ (Congestion Mitigation and Air Quality Improvement) Program provides over $\$ 8.6$ billion dollars in funds to State DOTs, MPOs, and transit agencies to invest in projects that reduce criteria air pollutants regulated from transportation-related sources over a period of five years.

http://www.fta.dot.gov/grants financing.html http://www.fhwa.dot.gov/environment/cmaqpgs/

\section{STATE FUNDING}

Bicycle Transportation Account (Caltrans) provides state funds for City and County projects that improve safety and convenience for bicycle commuters. To be eligible for BTA funds, a city or county must prepare and adopt a Bicycle Transportation Plan (BTP) that complies with Streets and Highways Code Section 891.2.

http://www.dot.ca.gov/hq/LocalPrograms/bta/btawebPage.htm

Transportation Development Act (TDA) Department of Transportation (Caltrans Mass Transportation Division) provides two major sources of funding for public transportation: the Local Transportation Fund (LTF) and the State Transit Assistance fund (STA). These funds are allocated to areas of each county based on population, taxable sales and transit performance for the development and support of public transportation needs. Some counties have the option of using LTF for local streets and roads projects if there are no unmet transit needs.

http://www.dot.ca.gov/hq/MassTrans/State-TDA.html

Database of State Incentives for Renewables \& Efficiency provides funding options available for energy efficiency and renewable energy projects.

http://www.dsireusa.org

Energy Efficiency Financing Program (California Energy Commission) provides financing for schools, hospitals and local governments through lowinterest loans for feasibility studies and the installation of energy-saving measures.

http://www.energy.ca.gov/efficiency/financing/ 
Energy Partnership Program (California Energy Commission) offers a free energy audit of municipal buildings.

http://www.energy.ca.gov/efficiency/partnership/

Bright School Program (California Energy Commission) assists K-12 schools with energy efficiency projects.

http://www.energy.ca.gov/efficiency/brightschools/

California Solar Initiative (CSI) solar rebate program through the California Public Utilities Commission (CPUC), provides financial incentives for solar installation.

http://www.cpuc.ca.gov/PUC/energy/solar

http://www.gosolarcalifornia.ca.gov/csi/index.html

California Tax Code Section 73 offers a property tax exemption equal to the increased property value from a solar system installed as a retrofit before January l, 2010.

Self-Generation Incentive Program (SGIP) through the California Public Utilities Commission (CPUC). http://www.cpuc.ca.gov

http://www.cpuc.ca.gov/PUC/energy/DistGen/sgip/

Tax-exempt and taxable bonds (California Alternative Energy \& Advanced Transportation Financing Authority) for projects that use alternative energy sources and technologies.

http://www.treasurer.ca.gov/caeatfa/

California Integrated Waste Management Board (CIWMB) offers funding to assist public and private entities in the safe and effective management of waste.

http://www.ciwmb.ca.gov/Grants/

State Water Resources Control Board, Division of Financial Assistance (DFA) includes loan and grant funding for construction of municipal sewage and water recycling facilities, remediation for underground storage tank releases, watershed protection projects, nonpoint source pollution control projects, etc. DFA also administers the Water Recycling Program and the Operator Certification Program.

http://www.swrcb.ca.gov/water issues/programs/grants loans/

Integrated Regional Water Management Grant Program (IRWM) promotes integrated regional water management to ensure sustainable water uses, reliable water supplies, better water quality, environmental stewardship, efficient urban development, protection of agriculture, and a strong economy.

http://www.swrcb.ca.gov/water issues/programs/grants loans/irwmgp/inde $\underline{\mathrm{x} . \mathrm{shtml}}$ 
Water Recycling Funding Program (WRFP) promotes the beneficial use of treated municipal wastewater (water recycling) in order to augment fresh water supplies by providing technical and financial assistance in support of water recycling projects and research.

http://www.swrcb.ca.gov/water issues/programs/grants loans/water recycli ng/index.shtml

Department of Water Resources website offers grants and loans.

http://www.water.ca.gov/nav/nav.cfm?loc=t\&\&id=103

\section{LOCAL \& REGIONAL FUNDING}

At the local level, the City may fund sustainability programs directly from the City's General Fund, and may include these programs as part of the City's Capital Improvement Project (CIP) funded in part by development impact fees (AB 1600 fees). The City may also use Redevelopment Agency funds within the Redevelopment Project Area to install energy efficient appliances, fixtures, and amenities. In a Revolving Loan Fund (RLF) funded by redevelopment, monies could be established to finance energy efficiency and green building programs within the Redevelopment Project Area.

As previously stated, it is expected that new sources of funding will become available over time. In addition, revenue generated from the City's LEED and GreenPoint Rated consulting services can be used to fund sustainability projects, along with monies saved directly by the City as a result of increased efficiency in the use of water and energy.

The City should also consider partnering with other agencies such as the San Joaquin Valley Air Pollution Control District (SJVAPCD), the Stanislaus Council of Governments (StanCOG), Stanislaus Regional Transit Agency (StaRT), Stanislaus County, the Stanislaus Economic Development Workforce and Alliance.

The City may also wish to consider the sale of municipal bonds, local sales tax measures, new metered parking fees in downtown, increased park user fees, new development impact fees, or in-lieu fees to fund sustainability projects.

\section{PRIVATE FUNDING}

The City should encourage residents and private businesses to take advantage of rebates available through their utility companies. For example, Pacific Gas \& Electric Company (PG\&E) offers rebates for the purchase of high-efficiency gas water heaters, dish \& clothes washers, and natural gas furnaces. The Turlock Irrigation District (TID) offers rebates for the following purchases by their customers:

- $\$ 10$ rebate when customers spend $\$ 20$ on compact fluorescent light bulbs (CFLs)

- Rebate when customers purchase a new ENERGY STAR ${ }^{\circledR}$ appliance such as a clothes washer, refrigerator, or a room air conditioner 
- $\$ 35$ rebate to use towards the purchase of a more energy-efficient refrigerator and help recycling old models

- $\$ 20$ rebate per tree when planting new shade trees to help cool the house in the summer

- Sun Screen Rebate: \$1 per square foot for customers who cover their windows with heavy duty vinyl coated shade screens that block at least $80 \%$ of the sun's heat

- \$75 rebate for purchasing and installing a whole house fan

- Rebate of 40-cents per square foot for new residential homes that incorporate energy efficiency measures and meet the program requirements:

o Builders must achieve a 35\% reduction in the structure's combined space heating, cooling, and water-heating energy

o Builders must achieve a $40 \%$ reduction in the building's air conditioning energy compared to specifications contained in the Title 24 of the state's Building Energy Efficiency Standards

o All appliances must be ENERGY STAR rated

o Independent on-site testing and inspections are required to verify the energy efficiency measures

- Rebate to offset a portion of the purchase cost for the installation of home photovoltaic (PV) systems http://www.tid.org/Residential/Rebates/index.htm

As with agency funding, the City should consider partnering with the Chamber of Commerce, the Patterson Joint Unified School District (PJUSD), utility companies (TID, PG\&EE), waste collection and recycling agencies (Bertolotti), local manufacturers and corporate distribution centers (e.g. Kohl's, CVS Pharmacy), and the San Joaquin Valley Clean Energy Organization (SJVCEO), under the California Partnership for the San Joaquin Valley.

The City should also encourage residents and other local businesses to privately invest in, and finance, their own projects to improve sustainability. The City can also seek out private contributions from community organizations, non-profit agencies (e.g. land trusts such as the American Farmland Trust for conservation easement acquisition), local businesses, and corporations, to sponsor individual City projects improving sustainability.

\section{ADDITIONAL FUNDING RESOURCES}

The following is a list of additional potential funding resources:

San Joaquin Valley Air Pollution Control District (SJVAPCD) provides grants and incentives for a variety of measures to improve air quality. http://www.valleyair.org/Grant Programs/GrantPrograms.htm 
Great Valley Center The Great Valley Solar Partnership website lists state and federal financial incentives for solar installation and other types of renewable energy.

http://www.greatvalley.org/energy/solarincent.aspx

San Joaquin Valley Clean Energy Organization (SJVCEO) website provides funding currently available from federal, state, utility, foundation, and other sources. http://www.sjvcleanenergy.org/finding-funding

Local Government Commission (LGC) website lists funding opportunities for local governments. http://www.lgc.org/freepub/energy/funding.html

Cool California website has resources listed specifically for Local Government, as well as resources organized by categories for Households, Small Businesses, Youth, Community Organizations, and Schools. http://www.coolcalifornia.org/article/find-resources

\section{CARB Air Pollution Incentives, Grants and Credit Programs}

The California Air Resources Board (CARB) website provides links to Grant Programs for Clean On- and Off-Road Vehicles and Equipment, with hundreds of millions of dollars in grants available to reduce emissions from on- and off-road vehicles and equipment. Vehicle and equipment owners typically must apply for funds. The CARB website has Other Incentive and Equipment Grant Programs providing incentives for actions that reduce emissions, for technology demonstration projects, and other clean air initiatives. The CARB website also provides links to information regarding state and federal air quality financing opportunities, as well as information regarding state emission reduction credits and other offset programs. http://www.arb.ca.gov/ba/fininfo.htm

ICLEI (USA) website provides potential funding sources. http://www.icleiusa.org/

ICLEI (USA) Economic Recovery Funding Updates website provides the latest information on funding made available through the American Recovery and Reinvestment Act (AARA). http://www.icleiusa.org/action-center/financing-staffing/stimulus-fundingupdates

PMC Carbon Conscious website provides information on grants, rebates, and low-interest loan programs designed specifically for local climate action plans, greenhouse gas inventories, public outreach programs, and projects that reduce GHG emissions. http://carbonconscious.us/funding.html 
APPENDIX 


\section{APPENDIX A \\ BEST PRACTICES REVIEW}

\section{INTRODUCTION}

Planning for climate change and sustainability is a relatively new practice in local and regional planning agencies. This document provides a summary of the most recent, state-of-the-art planning practices, derived from Sustainability Plans, Climate Action Plans, and General Plan Elements that incorporate principles of sustainability, how other jurisdictions have chosen to address these issues (what plan format was used), and which ideas, approaches, and techniques can be applied to Patterson. The process of compiling this document has helped inform the determination of which plan format option is most appropriate for adoption and implementation in the City of Patterson.

For purposes of this study, "best practices" are policies, actions, and indicators that provide specific measures to achieve a more sustainable City through practices of water conservation, energy conservation, compact urban form and growth, jobs/housing balance, waste reduction and recycling, carbon sequestration, improved air quality, and outreach \& awareness. This summary is intended to provide an overview of the range of approaches being applied in other jurisdictions. While there are many quality plans (Sustainability Plans, Climate Action Plans, and General Plan Elements) that have been adopted over the past few years, only a few were selected for innovative strategies combating climate change and achieving greater sustainability. The cities chosen are generally from California, but cities from around the nation (e.g. Seattle) with a strong reputation and initiative in successfully moving toward sustainability were also studied. Some plans have stronger, more comprehensive actions in the Waste Reduction \& Recycling focus area, for example, while others have a more complete section on Agricultural Preservation. The City of Fresno's Plan was important for review because it has many similar characteristics when compared to the City of Patterson, such as the continuing outward urban sprawl pattern, contributing to the loss of agricultural lands. Not all strategies being implemented elsewhere are appropriate for Patterson. However, many of these approaches will help conjure up alternatives that can be adapted for Patterson. The following documents were reviewed:

\section{SUSTAINABILITY PLANS}

- Sacramento Creating A Sustainable City: Implementation Plan (February 2008)

- Burbank Sustainability Action Plan (January 2008)

- Fresno Green: The City of Fresno's Strategy for Achieving Sustainability (May 2008)

- City of Santa Monica Sustainable City Plan (October 2006)

- City of Pasadena Green City Action Plan (2006) 


\section{SUSTAINABILITY ELEMENT OF GENERAL PLAN}

- City of Grand Terrace Sustainable Development Element (January 2008 Draft)

- Boulder County Comprehensive Plan Sustainability Element (May 2007)

- City of Benicia Community Development and Sustainability Element (1999)

\section{SUSTAINABILITY THROUGHOUT THE GENERAL PLAN}

- Marin Countywide Plan (November 2007)

\section{Climate action Plans}

- City of Los Angeles: Green LA - An Action Plan to Lead the Nation In Fighting Global Warming (May 2007)

- Meeting the Kyoto Challenge: Seattle Climate Action Plan (September 2006)

- San Francisco Climate Action Plan (September 2004)

\section{MODEL POLICIES, ACTIONS \& INDICATORS}

This summary of actions toward achieving sustainability is organized into nine broad policy areas: Land Use \& Community Design, Transportation, Energy, Waste Reduction \& Recycling, Water, Sustainable Economic Development, Natural Resources, Public Health, and Outreach \& Awareness. Each section lists model policies, programs, indicators (to measure the effectiveness), and quantifiable objectives (targets) that warrant review by the City of Patterson. Outreach measures, where relevant, are included in each policy area. The Outreach $\&$ Awareness section details efforts applicable to many policy areas.

\section{LAND USE \& COMMUNITY DESIGN}

Inefficient, spread-out development known as sprawl can encourage automobile use. This pattern of community design forces residents to drive long distances to work, school, and commercial destinations, while increasing dependence on motor vehicles, wasting fuel, and contributing to air pollution and increased greenhouse gas emissions. Infill, mixed-use, transit-oriented, compact, and higher-density development is the solution being applied in many jurisdictions, discouraging and reducing the use of personal vehicles.

\section{COMPACT \& MIXED USE DEVELOPMENT}

One strategy for reducing dependence on motor vehicles, is to return to traditional neighborhood design, increase density, and mix land uses housing, retail, entertainment, and employment - to be more conducive to walking and biking, reduce the obesity rate, and improve health. With thousands of new housing units being developed, there is great potential to have an enormous impact on sustainability by encouraging higher density and limiting residential building size in new development to achieve a decline in energy use. 


\begin{tabular}{|c|c|}
\hline Action & Source \\
\hline $\begin{array}{l}\text { Create compact, mixed-use projects, forming } \\
\text { urban villages designed to encourage walking, } \\
\text { bicycling and the use of existing and future } \\
\text { public transit systems. }\end{array}$ & Santa Monica Sustainable City Plan \\
\hline $\begin{array}{l}\text { Ensure that new development is compatible } \\
\text { with adjacent existing development and does } \\
\text { not detract from Benicia's small town qualities } \\
\text { and historic heritage. }\end{array}$ & $\begin{array}{l}\text { Benicia Community Development and } \\
\text { Sustainability Element }\end{array}$ \\
\hline A discernible center - plaza \& transit stop & Marin Countywide Plan \\
\hline $\begin{array}{l}\text { Buildings close to the sidewalk and to each } \\
\text { other }\end{array}$ & Marin Countywide Plan \\
\hline $\begin{array}{l}\text { Dwellings mostly within } 5 \text { minute walk from the } \\
\text { center }\end{array}$ & Marin Countywide Plan \\
\hline A variety of dwelling types & Marin Countywide Plan \\
\hline Encourage second units. & Marin Countywide Plan \\
\hline Encourage home offices. & Marin Countywide Plan \\
\hline Encourage narrow roads, shaded by trees. & Marin Countywide Plan \\
\hline $\begin{array}{l}\text { Garages and parking at rear of buildings (alleys } \\
\text { okay). }\end{array}$ & Marin Countywide Plan \\
\hline $\begin{array}{l}\text { The City shall promote mixed-use development } \\
\text { projects that coordinate land uses with } \\
\text { transportation systems and parks and open } \\
\text { space in an effort to create a walkable } \\
\text { neighborhood environment. }\end{array}$ & $\begin{array}{l}\text { Grand Terrace Sustainable } \\
\text { Development Element }\end{array}$ \\
\hline $\begin{array}{l}\text { Identify urban infill parcels instead of greenfields } \\
\text { sites. Select sites that have existing public } \\
\text { services and facilities. }\end{array}$ & $\begin{array}{l}\text { Grand Terrace Sustainable } \\
\text { Development Element }\end{array}$ \\
\hline Promote brownfields development. & $\begin{array}{l}\text { Grand Terrace Sustainable } \\
\text { Development Element }\end{array}$ \\
\hline $\begin{array}{l}\text { Select sites that are in close proximity to mass } \\
\text { transit lines and bikeways. }\end{array}$ & $\begin{array}{l}\text { Grand Terrace Sustainable } \\
\text { Development Element }\end{array}$ \\
\hline $\begin{array}{l}\text { Reduce the development footprint through } \\
\text { increased density. }\end{array}$ & $\begin{array}{l}\text { Grand Terrace Sustainable } \\
\text { Development Element }\end{array}$ \\
\hline $\begin{array}{l}\text { Increase density around activity centers and } \\
\text { transportation corridors to encourage trip } \\
\text { reduction through mixed-use development. }\end{array}$ & $\begin{array}{l}\text { Fresno Green } \\
\text { Marin Countywide Plan } \\
\text { Seattle Climate Action Plan }\end{array}$ \\
\hline $\begin{array}{l}\text { Update subdivision design standards to } \\
\text { promote vehicular and pedestrian connectivity. }\end{array}$ & Fresno Green \\
\hline $\begin{array}{l}\text { Increased height limits and greater development } \\
\text { flexibility in exchange for incorporating energy- } \\
\text { efficient green building practices and public } \\
\text { amenities. }\end{array}$ & Seattle Climate Action Plan \\
\hline $\begin{array}{l}\text { "Transit-oriented development" - compact, } \\
\text { mixed-use developments in which walking, } \\
\text { biking, and transit access are safe and easy. }\end{array}$ & Seattle Climate Action Plan \\
\hline Limit residential building size. & Marin Countywide Plan \\
\hline $\begin{array}{l}\text { Develop/review the TDR/TDC program (transfer } \\
\text { of development rights/credits). }\end{array}$ & Marin Countywide Plan \\
\hline $\begin{array}{l}\text { TDR incentives for landowners to voluntarily } \\
\text { build smaller, lightly impacting homes or } \\
\text { structures on vacant lands. }\end{array}$ & Boulder County Sustainability Element \\
\hline $\begin{array}{l}\text { Development which includes the conservation } \\
\text { of lands, materials, energy, and other resources } \\
\text { in its design, construction, and infrastructure; } \\
\text { and that preserves the rural character of the } \\
\text { County as well as the distinctive character of the } \\
\text { community in which development may be } \\
\text { located. }\end{array}$ & Boulder County Sustainability Element \\
\hline
\end{tabular}




\begin{tabular}{|l|l|}
\hline \multicolumn{1}{|c|}{ Action } & \multicolumn{1}{c|}{ Source } \\
\hline $\begin{array}{l}\text { All residents shall live within reasonable walking } \\
\text { distance }(1 / 2 \text { mile or } 1 / 4 \text { mile) of a park or } \\
\text { recreational open space. }\end{array}$ & $\begin{array}{l}\text { Fresno Green } \\
\text { Sacramento Implementation Plan } \\
\text { Pasadena Green City Action Plan }\end{array}$ \\
\hline
\end{tabular}

\section{AGRICULTURAL PRESERVATION}

Strategies to preserve agriculture promote sustainability by keeping more land available for carbon sequestration and less land that can worsen the Urban Heat Island Effect. They contribute to the local economy, reduce Vehicle Miles Traveled (VMT) when food is distributed locally rather than thousands of miles away, and can allow for improved public health. Best practices in agricultural preservation will also be discussed under Sustainable Economic Development and Public Health (Food Systems Planning).

\begin{tabular}{|l|l|}
\hline \multicolumn{1}{|c|}{ Action } & \multicolumn{1}{c|}{ Source } \\
\hline $\begin{array}{l}\text { Encourage merger of parcels on lands } \\
\text { protected by agricultural conservation } \\
\text { easements. }\end{array}$ & Marin Countywide Plan \\
\hline Facilitate land conservation contracts. & Marin Countywide Plan \\
\hline $\begin{array}{l}\text { Work with regional partners to develop an } \\
\text { agricultural land conservancy program. Apply } \\
\text { new program(s) within and outside of the City's } \\
\text { Sphere of Influence (SOI) by 2015. }\end{array}$ & Fresno Green \\
\hline $\begin{array}{l}\text { Initiate a variety of planning, regulatory, and } \\
\text { financial measures to ensure permanent } \\
\text { protection of agricultural and open space uses. }\end{array}$ & $\begin{array}{l}\text { Benicia Community Development } \\
\text { and Sustainability Element }\end{array}$ \\
\hline $\begin{array}{l}\text { No urban development is allowed beyond the } \\
\text { Urban Growth Boundary (requiring one or more } \\
\text { basic municipal services including, but not } \\
\text { limited to, water service, sewer, improved storm } \\
\text { drainage facilities, fire hydrants and other } \\
\text { physical public facilities and services. }\end{array}$ & $\begin{array}{l}\text { Benicia Community Development } \\
\text { and Sustainability Element }\end{array}$ \\
\hline
\end{tabular}

\section{PARKS AND OPEN SPACE}

Open space, parks, greenbelts, and trails offer opportunities for carbon sequestration (the absorption of carbon dioxide, mitigating the accumulation of greenhouse gases contributing to global warming) and bicycle \& pedestrian activity, reducing vehicle trips, and improving air quality and public health. Urban forestry (e.g. tree canopy coverage) will be discussed under Natural Resources.

\begin{tabular}{|c|c|}
\hline Action & Source \\
\hline $\begin{array}{l}\text { Develop and maintain a sufficient open space } \\
\text { system so that it is diverse in uses and } \\
\text { opportunities and includes natural } \\
\text { function/wildlife habitat as well as passive and } \\
\text { active recreation with an equitable distribution of } \\
\text { parks, trees, and pathways throughout the } \\
\text { community. }\end{array}$ & Santa Monica Sustainable City Plan \\
\hline
\end{tabular}




\begin{tabular}{|l|l|}
\hline \multicolumn{1}{|c|}{ Action } & \multicolumn{1}{c|}{ Source } \\
\hline $\begin{array}{l}\text { Indicator: Number of acres of public open space } \\
\text { by type (parks, public gathering places, } \\
\text { gardens, and other) } \\
\text { Target: Upward trend }\end{array}$ & Santa Monica Sustainable City Plan \\
\hline $\begin{array}{l}\text { Ensure new development includes open space, } \\
\text { trees, and other amenities. }\end{array}$ & Seattle Climate Action Plan \\
\hline $\begin{array}{l}\text { An open space impact fee on new development } \\
\text { to help fund public open space. }\end{array}$ & Seattle Climate Action Plan \\
\hline
\end{tabular}

\section{TRANSPORTATION}

A sustainable transportation system consists of pedestrian and bicycle improvements, trip reduction, alternative fuels, fuel efficiency, traffic flow improvements, improved public transit, and ridesharing.

\section{PEDESTRIAN \& BICYCLE IMPROVEMENTS}

Planning for an improved pedestrian and bicycle network, with better connectivity throughout the City, reduces traffic congestion and greenhouse gas (GHG) emissions, improves air quality and public health, reduces obesity rates, provides for a more friendly shopping environment which in turn helps the local economy, and improves the overall quality of life.

\begin{tabular}{|l|l|}
\hline \multicolumn{1}{|c|}{ Action } & \multicolumn{1}{|c|}{ Source } \\
\hline $\begin{array}{l}\text { Increase bicycling and walking as an alternative } \\
\text { to driving. }\end{array}$ & $\begin{array}{l}\text { San Francisco } \\
\text { Climate Action Plan }\end{array}$ \\
\hline $\begin{array}{l}\text { Give priority to pedestrian safety, access, and } \\
\text { transit over automobile speed and volume. }\end{array}$ & $\begin{array}{l}\text { Benicia Community Development } \\
\text { and Sustainability Element }\end{array}$ \\
\hline $\begin{array}{l}\text { Continue to increase the number of bicycle } \\
\text { lanes, routes, and paths. }\end{array}$ & $\begin{array}{l}\text { San Francisco } \\
\text { Climate Action Plan }\end{array}$ \\
\hline $\begin{array}{l}\text { Continue to improve safe access and passage } \\
\text { on pedestrian walkways. }\end{array}$ & $\begin{array}{l}\text { San Francisco } \\
\text { Climate Action Plan }\end{array}$ \\
\hline $\begin{array}{l}\text { Improve bicycle access to transit. } \\
\text { Provide a comprehensive system of pedestrian } \\
\text { and bicycle routes which link the various } \\
\text { components of the community: employment } \\
\text { centers, residential areas, commercial areas, } \\
\text { schools, parks, and open space. }\end{array}$ & Climate Action Plan \\
\hline $\begin{array}{l}\text { Require bicycle amenities as part of new } \\
\text { development projects. }\end{array}$ & Benicia Community Development \\
\hline $\begin{array}{l}\text { The City actively works with new developments } \\
\text { to install safe and convenient bicycle parking, } \\
\text { showers, and changing facilities on-site to } \\
\text { increase the opportunities and convenience for } \\
\text { bike riders. }\end{array}$ & $\begin{array}{l}\text { Pasadena Green City Action Plan } \\
\text { Climate Action Plan }\end{array}$ \\
\hline $\begin{array}{l}\text { The City shall require alternative transportation } \\
\text { plans for all major employment generators as } \\
\text { part of the development review process. }\end{array}$ & $\begin{array}{l}\text { Grand Terrace Sustainable } \\
\text { Development Element }\end{array}$ \\
\hline $\begin{array}{l}\text { Update street design standards to provide an } \\
\text { attractive bike and pedestrian environment. }\end{array}$ & Fresno Green \\
\hline $\begin{array}{l}\text { Better education and enforcement of traffic laws } \\
\text { as they relate to bicycle and pedestrian safety. }\end{array}$ & Seattle Climate Action Plan \\
\hline $\begin{array}{l}\text { Address opportunities to improve on-road } \\
\text { bicycling conditions, develop a way-finding } \\
\text { system, establish facility design guidelines, and }\end{array}$ & Seattle Climate Action Plan \\
\hline
\end{tabular}




\begin{tabular}{|l|l|}
\hline \multicolumn{1}{|c|}{ Action } & Source \\
\hline create a maintenance plan. & \\
\hline $\begin{array}{l}\text { Increase bike trails and lanes, improve } \\
\text { sidewalks and walkways and pedestrian street } \\
\text { crossings in high-use areas. }\end{array}$ & Seattle Climate Action Plan \\
\hline $\begin{array}{l}\text { Repair existing pedestrian infrastructure, its } \\
\text { sidewalks, trails, walkways, and stairways. }\end{array}$ & Seattle Climate Action Plan \\
\hline $\begin{array}{l}\text { Achieve an annual expansion of } 5 \% \text { of the } \\
\text { existing bikeway and pedestrian system. }\end{array}$ & Sacramento Implementation Plan \\
\hline $\begin{array}{l}\text { Research a new program to convert parking } \\
\text { meter poles into bike parking devices. }\end{array}$ & Sacramento Implementation Plan \\
\hline Bike parking rebate program. & Sacramento Implementation Plan \\
\hline $\begin{array}{l}\text { Achieve restoration of and public access along } \\
\text { all waterways, urban creeks, and riparian } \\
\text { corridors. }\end{array}$ & Sacramento Implementation Plan \\
\hline $\begin{array}{l}\text { Review discretionary permits with pedestrian } \\
\text { orientation, accessibility, and transit connectivity } \\
\text { in mind to provide transit and pedestrian } \\
\text { access. Review projects to ensure that } \\
\text { opportunities for open space are maximized. }\end{array}$ & Burbank Sustainability Action Plan \\
$\begin{array}{l}\text { Require all City departments (which represent } \\
\text { multiple disciplines) that review development } \\
\text { proposals to use this perspective. }\end{array}$ & \\
\hline
\end{tabular}

\section{TRIP REDUCTION}

Strategies to reduce the number of motor vehicles on the road reduce traffic congestion, lower greenhouse gas (GHG) emissions, and improve air quality and public health by way of clean air and more people walking and biking.

\begin{tabular}{|l|l|}
\hline \multicolumn{1}{|c|}{ Action } & \\
\hline $\begin{array}{l}\text { Discourage driving. } \\
\text { Progress Indicators: Decrease in traffic counts } \\
\text { on area roadways, Decrease in parking ratios in } \\
\text { new developments, Decrease in parking in } \\
\text { areas well-served by transit, Implement parking } \\
\text { fees, City Carshare (choice to not own a car by } \\
\text { providing alternative access to a vehicle when } \\
\text { one is needed), Increase the gas tax, Cap or } \\
\text { reduce the number of parking spaces }\end{array}$ & \\
\hline $\begin{array}{l}\text { Facilitate a reduction in automobile dependency } \\
\text { in favor of affordable alternative, sustainable } \\
\text { modes of travel. }\end{array}$ & Sante Action Plan \\
\hline $\begin{array}{l}\text { Reduce single-occupant vehicles through } \\
\text { increasing alternative transportation for } \\
\text { commute trips made by residents who live and } \\
\text { work in the City, strategies for trip reduction } \\
\text { through land use development standards that } \\
\text { encourage alternative transportation and } \\
\text { transportation demand management. }\end{array}$ & Plan \\
\hline $\begin{array}{l}\text { Purchase products produced locally to reduce } \\
\text { product transportation. }\end{array}$ & \\
\hline $\begin{array}{l}\text { Citywide commercial parking tax. More } \\
\text { expensive parking motivates people to choose } \\
\text { alternative transportation, or to limit the number } \\
\text { of trips that require paid parking. }\end{array}$ & Seattle Climate Action Plan \\
\hline Reduce by 20\% the number of commute trips by & Fresno Green \\
\hline
\end{tabular}




\begin{tabular}{|c|c|}
\hline Action & Source \\
\hline \multicolumn{2}{|l|}{$\begin{array}{l}\text { single occupancy vehicles from } 2000 \text { baseline } \\
\text { by } 2015 \text {. }\end{array}$} \\
\hline $\begin{array}{l}\text { Reduce long commutes by providing a wide } \\
\text { array of transportation and housing choices } \\
\text { near jobs for a balanced, healthy city. }\end{array}$ & Sacramento Implementation Plan \\
\hline Encourage City employees to drive less. & Sacramento Implementation Plan \\
\hline $\begin{array}{l}\text { Support trip reduction through employer-based } \\
\text { programs. Progress Indicators: Increase in the } \\
\text { percentage of all alternative modes combined } \\
\text { for commute trips, Increase in the number of } \\
\text { employers required to provide trip reduction } \\
\text { programs and incentives, Increase in the } \\
\text { percentage of City employees using alternative } \\
\text { modes for their commute. }\end{array}$ & $\begin{array}{l}\text { San Francisco } \\
\text { Climate Action Plan }\end{array}$ \\
\hline $\begin{array}{l}\text { Expand employer transportation management } \\
\text { requirements. Mandatory employer trip } \\
\text { reduction programs yield significantly greater } \\
\text { benefits than voluntary programs. }\end{array}$ & $\begin{array}{l}\text { San Francisco } \\
\text { Climate Action Plan }\end{array}$ \\
\hline $\begin{array}{l}\text { Offer incentives to employers who implement a } \\
\text { Transportation Demand Management Program } \\
\text { and commit to the goal of } 20 \% \text { reduction in } \\
\text { single occupancy vehicles in seven years. Such } \\
\text { programs may include provision of free bus } \\
\text { passes, a parking pricing program, preferential } \\
\text { parking for vanpools and carpools, bicycle racks } \\
\text { and lockers, and employee showers. }\end{array}$ & Fresno Green \\
\hline City employee rideshare program. & Los Angeles Climate Action Plan \\
\hline $\begin{array}{l}\text { Employee commute program. Incorporate } \\
\text { transit passes and incentives into benefits and } \\
\text { provide lockers and showers for bicycle } \\
\text { commuters. }\end{array}$ & Seattle Climate Action Plan \\
\hline $\begin{array}{l}\text { Indicator: Average vehicle ridership (AVR) of } \\
\text { businesses with more than } 50 \text { employees } \\
\text { Target: Upward trend in the use of sustainable } \\
\text { modes of transportation (bus, bike, pedestrian, } \\
\text { rail) }\end{array}$ & $\begin{array}{l}\text { Santa Monica Sustainable City } \\
\text { Plan }\end{array}$ \\
\hline $\begin{array}{l}\text { Indicator: Vehicle ownership - average number } \\
\text { of vehicles per person of driving age, percent of } \\
\text { total that are qualified low emission/alternative } \\
\text { fuel vehicles } \\
\text { Target: } 10 \% \text { reduction in the average number of } \\
\text { vehicles per person by } 2010\end{array}$ & $\begin{array}{l}\text { Santa Monica Sustainable City } \\
\text { Plan }\end{array}$ \\
\hline
\end{tabular}

\section{AlTERNATIVE FUELS \& FUEL EFFICIENCY}

Improving fuel efficiency reduces dependence on non-renewable energy sources and results in less greenhouse gas emissions and improved air quality. The development of such technologies also contributes to a healthier economy.

\begin{tabular}{|l|l|}
\hline \multicolumn{1}{|c|}{ Action } & \multicolumn{1}{c|}{ Source } \\
\hline $\begin{array}{l}\text { Increase the use of clean air vehicles and } \\
\text { improve fleet efficiency } \\
\text { City Fleet Vehicles } \\
\begin{array}{l}\text { Green Fleets, Alternative Fuel Vehicles } \\
\text { (AFVs) }\end{array}\end{array}$ & $\begin{array}{l}\text { San Francisco } \\
\text { Climate Action Plan }\end{array}$ \\
\hline
\end{tabular}




\begin{tabular}{|c|c|}
\hline Action & Source \\
\hline $\begin{array}{l}\text { Private Contractor Fleets } \\
\text { Public Transit Vehicles } \\
\text { Right Sizing and Down Sizing of the City Fleet } \\
\text { Progress Indicators: } \\
\text { - Increase in average vehicle fuel } \\
\text { efficiency [reported annually by EPA] } \\
\text { Decrease in the number of large and/or } \\
\text { inefficient vehicles registered in the } \\
\text { City } \\
\text { - Increase in the number of small, } \\
\text { efficient, and/or alternative fuel } \\
\text { vehicles registered } \\
\text { - Increase in the use of City Car Share } \\
\text { vehicles } \\
\text { Increase in the number/percentage of } \\
\text { clean vehicles in the City fleet } \\
\text { Increase in the percentage of clean air } \\
\text { public transit vehicles } \\
\text { Increase in the number of alternative } \\
\text { fueling stations in the City with public } \\
\text { access } \\
\text { Increase in the number of private fleets } \\
\text { implementing clean vehicle technology }\end{array}$ & \\
\hline $\begin{array}{l}\text { Indicator: Percent of City's non-emergency fleet } \\
\text { vehicles using alternative fuels (Public Works, } \\
\text { public transit buses, non-emergency policy and } \\
\text { fire vehicles) } \\
\text { Target: Upward trend in percentage of qualified } \\
\text { low emission/alternative fuel vehicles }\end{array}$ & $\begin{array}{l}\text { Santa Monica Sustainable City } \\
\text { Plan }\end{array}$ \\
\hline $\begin{array}{l}\text { Conversion of fleet vehicles to hybrid or electric } \\
\text { technology, and clean fuels. }\end{array}$ & Fresno Green \\
\hline $\begin{array}{l}\text { Replace all City-owned light equipment vehicles } \\
\text { with hybrid vehicles, and if not practical for } \\
\text { hybrid application, require a minimum of } 30 \\
\text { miles per gallon fuel efficiency by } 2017 \text {. }\end{array}$ & Fresno Green \\
\hline $\begin{array}{l}\text { Hybrid electric cars are the standard sub- } \\
\text { compact in the City fleet and Segways (battery } \\
\text { operated personal mobility vehicles) are used } \\
\text { for water meter reading, security at Seattle } \\
\text { Center, and for Seattle Police to patrol large } \\
\text { events. }\end{array}$ & Seattle Climate Action Plan \\
\hline $\begin{array}{l}\text { Require } 85 \% \text { of the City fleet to be powered by } \\
\text { alternative fuels. }\end{array}$ & Los Angeles Climate Action Plan \\
\hline $\begin{array}{l}\text { Purchase of Gasoline/Electric Hybrid Vehicles, } \\
\text { Liquefied Natural Gas refuse trucks, and Flex } \\
\text { Fuel (E85 capable) vehicles. }\end{array}$ & Sacramento Implementation Plan \\
\hline $\begin{array}{l}\text { Target of } 25 \% \text { of new light duty fleet vehicles to } \\
\text { be flexible fuel, hybrid, electric, or fuel cell. }\end{array}$ & Sacramento Implementation Plan \\
\hline $\begin{array}{l}\text { Replacement of diesel-fueled trucks with natural } \\
\text { gas fueled trucks for solid waste operations. }\end{array}$ & Sacramento Implementation Plan \\
\hline $\begin{array}{l}\text { Convert } 100 \% \text { of City refuse collection trucks } \\
\text { and street sweepers to alternative fuels. }\end{array}$ & Los Angeles Climate Action Plan \\
\hline $\begin{array}{l}\text { Convert } 100 \% \text { of MTA buses to alternative } \\
\text { fuels. }\end{array}$ & Los Angeles Climate Action Plan \\
\hline $\begin{array}{l}\text { For 2012, reduce per capita fleet fuel } \\
\text { consumption by } 15 \% \text { relative to baseline year of } \\
2003 \text {. }\end{array}$ & Sacramento Implementation Plan \\
\hline Vehicle "right-sizing" program. & Sacramento Implementation Plan \\
\hline
\end{tabular}




\begin{tabular}{|c|c|}
\hline Action & Source \\
\hline $\begin{array}{l}\text { Fleet Reduction. Conduct fleet size and } \\
\text { utilization study. }\end{array}$ & Burbank Sustainability Action Plan \\
\hline $\begin{array}{l}\text { Parks Department replacing gas-powered } \\
\text { mowers and other equipment with electric or } \\
\text { hybrid electric models. }\end{array}$ & Seattle Climate Action Plan \\
\hline $\begin{array}{l}\text { City's Department of General Services: pilot } \\
\text { global positioning system (GPS) implementation } \\
\text { on city fleet vehicles. The GPS tracks idle time, } \\
\text { speeding violations, miles per gallon, engine } \\
\text { problems, and trip distances. The data obtained } \\
\text { from this system thus far shows great promise } \\
\text { in monitoring and controlling excessive idle time } \\
\text { and reducing fuel consumption. }\end{array}$ & Sacramento Implementation Plan \\
\hline $\begin{array}{l}\text { Retrofitting diesel-powered vehicles with } \\
\text { particulate traps. }\end{array}$ & Sacramento Implementation Plan \\
\hline $\begin{array}{l}\text { Install advanced emission control devices for } \\
\text { the City fleet of diesel-fueled off-road } \\
\text { equipment. }\end{array}$ & Burbank Sustainability Action Plan \\
\hline $\begin{array}{l}\text { Reduce vehicle idling by equipping five trucks } \\
\text { with power inverters - devices that enable } \\
\text { equipment to run off batteries without using the } \\
\text { truck engine. }\end{array}$ & Seattle Climate Action Plan \\
\hline $\begin{array}{l}\text { Increase the percentage of biodiesel blend used } \\
\text { in City vehicles and equipment from B20 to as } \\
\text { much as B40. }\end{array}$ & Seattle Climate Action Plan \\
\hline Purchase E-85 ethanol and B-5 bio-diesel fuel. & Sacramento Implementation Plan \\
\hline $\begin{array}{l}\text { The City purchases ultra low sulfur diesel fuel in } \\
\text { compliance with state and federal regulations. }\end{array}$ & Burbank Sustainability Action Plan \\
\hline $\begin{array}{l}\text { Preferred parking for low emission, alternative } \\
\text { energy, and carpool vehicles. }\end{array}$ & $\begin{array}{l}\text { Grand Terrace Sustainable } \\
\text { Development Element }\end{array}$ \\
\hline $\begin{array}{l}\text { Electric mulching lawn mower rebate program to } \\
\text { ensure old mowers are turned in for disposal } \\
\text { and not used elsewhere. }\end{array}$ & Seattle Climate Action Plan \\
\hline $\begin{array}{l}\text { Develop plug-in hybrid and electric vehicle } \\
\text { charging station infrastructure by } 2009 .\end{array}$ & Fresno Green \\
\hline $\begin{array}{l}\text { Begin installation of alternative fueling } \\
\text { infrastructure. }\end{array}$ & Sacramento Implementation Plan \\
\hline $\begin{array}{l}\text { The City shall encourage the use of zero- } \\
\text { emission vehicles, low-emission vehicles, and } \\
\text { car sharing programs by requiring sufficient and } \\
\text { convenient infrastructure and parking facilities in } \\
\text { residential developments and employment } \\
\text { centers to accommodate these vehicles and } \\
\text { programs. }\end{array}$ & Sacramento Implementation Plan \\
\hline
\end{tabular}

\section{TRAFFIC FLOW IMPROVEMENTS}

By improving traffic flow and reducing congestion, vehicle idling time is minimized, resulting in less greenhouse gas emissions, and improved air quality and public health.

\begin{tabular}{|l|l|}
\hline \multicolumn{1}{|c|}{ Action } & \multicolumn{1}{|c|}{ Source } \\
\hline $\begin{array}{l}\text { Indicator: Traffic congestion - number of } \\
\text { signalized intersections with unacceptable } \\
\text { motor vehicle congestion (LOS D, E, or F) } \\
\text { during peak hours. Target: Downward trend }\end{array}$ & $\begin{array}{l}\text { Santa Monica Sustainable City } \\
\text { Plan }\end{array}$ \\
\hline
\end{tabular}




\begin{tabular}{|l|l|}
\hline \multicolumn{1}{|c|}{ Action } & \multicolumn{1}{|c|}{ Source } \\
\hline $\begin{array}{l}\text { Indicator: Traffic congestion - LOS for } \\
\text { sustainable modes of transportation at impacted } \\
\text { intersections. Target: Upward trend }\end{array}$ & $\begin{array}{l}\text { Santa Monica Sustainable City } \\
\text { Plan }\end{array}$ \\
\hline
\end{tabular}

\section{PUBLIC TRANSIT}

Improved public transit service reduces the number of vehicles on the road, improving traffic flow and reducing congestion, resulting in less greenhouse gas emissions, and improved air quality and public health.

\begin{tabular}{|c|c|}
\hline Action & Source \\
\hline $\begin{array}{l}\text { Increase the use of public transit as an } \\
\text { alternative to driving. } \\
\text { Progress Indicator: Increase in the percentage } \\
\text { of transit trips. }\end{array}$ & $\begin{array}{l}\text { San Francisco } \\
\text { Climate Action Plan }\end{array}$ \\
\hline $\begin{array}{l}\text { Transit First Policy: gives priority to public transit } \\
\text { investments and provides street capacity and } \\
\text { parking policies to discourage increases in } \\
\text { automobile traffic. Designated transit lanes and } \\
\text { streets and improved signalization, and } \\
\text { increased transit service to meet the needs } \\
\text { generated by new development. }\end{array}$ & $\begin{array}{l}\text { San Francisco } \\
\text { Climate Action Plan }\end{array}$ \\
\hline Expand local transit service. & $\begin{array}{l}\text { San Francisco } \\
\text { Climate Action Plan }\end{array}$ \\
\hline $\begin{array}{l}\text { Expand and improve regional transit service } \\
\text { and connections. }\end{array}$ & $\begin{array}{l}\text { San Francisco } \\
\text { Climate Action Plan }\end{array}$ \\
\hline $\begin{array}{l}\text { Develop a transportation impact fee to new } \\
\text { construction and commercial space. }\end{array}$ & $\begin{array}{l}\text { San Francisco } \\
\text { Climate Action Plan }\end{array}$ \\
\hline $\begin{array}{l}\text { Indicator: Bus ridership - annual ridership, } \\
\text { percent of residents who have ridden the bus in } \\
\text { the past year, annual ridership on regional } \\
\text { routes originating in the Santa Monica } \\
\text { Target: Upward trend }\end{array}$ & $\begin{array}{l}\text { Santa Monica Sustainable City } \\
\text { Plan }\end{array}$ \\
\hline $\begin{array}{l}\text { Promote the development of better public transit } \\
\text { services through collaboration with regional and } \\
\text { subregional transit planning groups. }\end{array}$ & Burbank Sustainability Action Plan \\
\hline $\begin{array}{l}\text { Continue to produce and distribute marketing } \\
\text { materials including route maps and schedules } \\
\text { for the City's shuttle service. Continue to update } \\
\text { materials as routes and services change. }\end{array}$ & Burbank Sustainability Action Plan \\
\hline
\end{tabular}

\section{RIDESHARING}

Increased ridesharing reduces the number of vehicles on the road, improving traffic flow and reducing congestion, resulting in less greenhouse gas emissions, and improved air quality and public health.

\begin{tabular}{|l|l|}
\hline \multicolumn{1}{|c|}{ Action } & \multicolumn{1}{c|}{ Source } \\
\hline $\begin{array}{l}\text { Increase the use of ridesharing as an alternative } \\
\text { to single occupancy driving. } \\
\text { Progress Indicators: Increase in the percentage } \\
\text { of carpool and vanpool trips, Increase in the } \\
\text { number of carpool/vanpool ridematches, } \\
\text { Increase in the number of carpool/vanpool }\end{array}$ & $\begin{array}{l}\text { San Francisco } \\
\text { Climate Action Plan }\end{array}$ \\
\hline
\end{tabular}




\begin{tabular}{|l|l|}
\hline \multicolumn{1}{|c|}{ Action } & \multicolumn{1}{c|}{ Source } \\
\hline $\begin{array}{l}\text { parking spaces at municipal and private parking } \\
\text { lots, High level of participation in school } \\
\text { ridesharing program }\end{array}$ & \\
\hline Implement school ridesharing program. & $\begin{array}{l}\text { San Francisco } \\
\text { Climate Action Plan }\end{array}$ \\
\hline $\begin{array}{l}\text { Preferential parking, e.g. designated carpool } \\
\text { and vanpool parking. }\end{array}$ & $\begin{array}{l}\text { San Francisco } \\
\text { Climate Action Plan }\end{array}$ \\
\hline $\begin{array}{l}\text { Establish a vehicle pool for vehicle sharing by } \\
\text { all City departments. }\end{array}$ & Burbank Sustainability Action Plan \\
\hline Expand the City rideshare program. & Los Angeles Climate Action Plan \\
\hline
\end{tabular}

\section{OUTREACH \& AWARENESS}

In order to achieve a more sustainable transportation system, it is imperative for cities to reach out to the community because improving City operations, while important, can only do so much. Businesses and residents should also be willing to change their behavior for the betterment of public health, safety, and welfare.

\begin{tabular}{|c|c|}
\hline Action & Source \\
\hline $\begin{array}{l}\text { "Drive Smart" component focused on fuel } \\
\text { efficiency: what to look for when purchasing a } \\
\text { car, maintenance and driving tips to increase } \\
\text { mileage, and tips for driving less. The campaign } \\
\text { will include a variety of media, messages, } \\
\text { workshops, and events tailored to reach specific } \\
\text { audiences. }\end{array}$ & Seattle Climate Action Plan \\
\hline $\begin{array}{l}\text { Drive smart. Keep cars and trucks tuned and } \\
\text { tires properly inflated, more moderate speeds, } \\
\text { bundle errands together. Don't idle - about } 15 \\
\text { seconds is the breakeven point. Forget jack } \\
\text { rabbit starts; they cut fuel efficiency by } 31 \% \text { ! On } \\
\text { the high-way, drive the speed limit. You'll do } \\
\text { more than cut emissions, you will avoid tickets, } \\
\text { improve safety, reduce stress, and lower car } \\
\text { maintenance bills. }\end{array}$ & Seattle Climate Action Plan \\
\hline $\begin{array}{l}\text { Drive the cleanest vehicle you can. If you } \\
\text { double the mileage of your vehicle, you'll halve } \\
\text { the greenhouse gas emissions. Plus, new gas- } \\
\text { electric hybrid vehicles are eligible for a federal } \\
\text { tax credit. Alternative fuels like biodiesel and } \\
\text { ethanol also cut emissions. }\end{array}$ & Seattle Climate Action Plan \\
\hline $\begin{array}{l}\text { Make transit information easily available, } \\
\text { understandable, and translated into multiple } \\
\text { languages. }\end{array}$ & Los Angeles Climate Action Plan \\
\hline $\begin{array}{l}\text { Promote walking ad biking to work, within } \\
\text { neighborhoods, and to large events and } \\
\text { venues. }\end{array}$ & Los Angeles Climate Action Plan \\
\hline $\begin{array}{l}\text { Increase marketing and promotion of bicycling, } \\
\text { public transit, and ridesharing. }\end{array}$ & $\begin{array}{l}\text { San Francisco } \\
\text { Climate Action Plan }\end{array}$ \\
\hline $\begin{array}{l}\text { Expand employer commute assistance and } \\
\text { outreach. Educate them about the various trip- } \\
\text { reduction strategies available (commuter tax } \\
\text { benefits, parking cash-out, telecommuting, etc.). }\end{array}$ & $\begin{array}{l}\text { San Francisco } \\
\text { Climate Action Plan }\end{array}$ \\
\hline
\end{tabular}




\section{ENERGY}

According to the Los Angeles Climate Action Plan (2007), conservation is the most effective strategy for meeting energy demand (p.4). Replacing a single incandescent bulb with a CFL reduces $\mathrm{CO} 2$ emissions from electricity consumption by 65.2 pounds/year (p.20). This section lays out best practices in green building, renewable energy/power purchasing, energy conservation / demand reduction, and outreach \& awareness.

\section{GREEN BUILDING}

As mentioned in the Los Angeles Climate Action Plan (2007), "buildings in the United States use one-third of total energy consumed in the country, two-thirds of the electricity consumed, and produce 30\% of GHG emissions. Since the expected lifetime of a new building is about 100 years, actions taken today during this period of rapid expansion will have lasting repercussions on the ability to achieve long-term sustainability" (p.19).

Sustainable design techniques, known as green building practices, improve energy efficiency and water conservation, provide for optimum indoor air quality, obtain materials locally rather than from thousands of miles away, minimize the use of and impact on natural resources, and include numerous other benefits for the building's occupants and the environment.

\begin{tabular}{|c|c|}
\hline Action & Source \\
\hline $\begin{array}{l}\text { Strengthen legislation, codes, and standards. } \\
\text { Progress Indicators: Enforcement reports show } \\
\text { high level of compliance, Energy usage reports } \\
\text { show decreased demand (kilowatts) and energy } \\
\text { use (kilowatt-hours, therms), Number of } \\
\text { buildings obtaining LEED silver certification } \\
\text { - Expand energy efficiency requirements } \\
\text { for existing buildings } \\
\text { - Strengthen local buildings codes for } \\
\text { new construction and renovation } \\
\text { Green Building Ordinance (LEED } \\
\text { Silver as a standard for all new } \\
\text { construction, renovation, and additions } \\
\text { over a certain square footage) }\end{array}$ & San Francisco Climate Action Plan \\
\hline $\begin{array}{l}\text { Develop a mandatory program for Municipal } \\
\text { buildings modeled after the California State } \\
\text { Green Building Standards. }\end{array}$ & Burbank Sustainability Action Plan \\
\hline $\begin{array}{l}\text { The City shall implement green building } \\
\text { practices into all new municipal projects. }\end{array}$ & $\begin{array}{l}\text { Grand Terrace Sustainable } \\
\text { Development Element }\end{array}$ \\
\hline $\begin{array}{l}\text { Mandate LEED certification for all new City- } \\
\text { owned buildings. }\end{array}$ & Sacramento Implementation Plan \\
\hline $\begin{array}{l}\text { Incorporate "green" building practices into the } \\
\text { review of all new or renovated development } \\
\text { projects. }\end{array}$ & $\begin{array}{l}\text { Grand Terrace Sustainable } \\
\text { Development Element }\end{array}$ \\
\hline $\begin{array}{l}\text { The City shall review its Zoning Ordinance and } \\
\text { Building Codes to promote green building } \\
\text { concepts into all development projects including } \\
\text { possible incentives for the expanded use of } \\
\text { green building concepts. }\end{array}$ & $\begin{array}{l}\text { Grand Terrace Sustainable } \\
\text { Development Element }\end{array}$ \\
\hline For 2012, achieve 30\% LEED-type certification & Sacramento Implementation Plan \\
\hline
\end{tabular}




\begin{tabular}{|l|l|}
\hline \multicolumn{1}{|c|}{ Action } & \multicolumn{1}{c|}{ Source } \\
\hline $\begin{array}{l}\text { of new construction within the City. For 2030, } \\
\text { achieve 80\%. }\end{array}$ & \\
\hline $\begin{array}{l}\text { Establish and continuously improve "green" } \\
\text { building standards for both residential and } \\
\text { commercial development-new and remodeled. }\end{array}$ & Sacramento Implementation Plan \\
\hline $\begin{array}{l}\text { For 2030, per the California Energy Commission } \\
\text { regulation, all new construction within City limits } \\
\text { will be carbon neutral. }\end{array}$ & Sacramento Implementation Plan \\
\hline $\begin{array}{l}\text { The green building program will offer property } \\
\text { owners flexibility and options in determining } \\
\text { which materials and techniques meet their } \\
\text { needs and desires for complying with the } \\
\text { standards set by regulations and codes. }\end{array}$ & $\begin{array}{l}\text { Boulder County Sustainability } \\
\text { Element }\end{array}$ \\
\hline
\end{tabular}

The following is a non-exhaustive list of cities with green building programs in California:

- City of Berkeley

o Berkeley Best Builders program

o Green Remodeling in Berkeley Guide

- City of Davis

- City of Fresno (incentive-based)

- City of Irvine

- City of Oakland

- City of Pasadena (mandatory by ordinance)

- City of Santa Monica (mandatory by ordinance + guidelines)

o City of Santa Monica Residential Green Building Guide

- City of Sacramento (pursuing)

- City of Santa Barbara

o Built Green Santa Barbara (voluntary, expedited plan check review)

\section{RENEWABLE ENERGY/POWER PURCHASING}

Renewable energy includes solar, wind, geothermal, and other sources. Many cities are developing a Renewable Energy Standard Portfolio, requiring a certain percentage of citywide electricity to be generated from renewable sources. Some power utilities offer consumers the option to pay a surcharge to use renewable energy to power their homes.

The City of Los Angeles is uniquely positioned to diversify its sources of energy because the City owns the power utility (LADWP). Pasadena Water $\&$ Power (PWP) also has a Green Power Program. Some jurisdictions are studying the possibility of Community Choice Aggregation (CCA), such as the County of Marin and its cities through Marin Clean Energy (MCE).

\begin{tabular}{|l|l|}
\hline \multicolumn{1}{|c|}{ Action } & \multicolumn{1}{|c|}{ Source } \\
\hline $\begin{array}{l}\text { Develop renewable energy projects (solar, wind, } \\
\text { biomass). }\end{array}$ & San Francisco Climate Action Plan \\
$\begin{array}{l}\text { Progress Indicators: Installed capacity } \\
\text { (kilowatts) and energy production (kilowatt- }\end{array}$ & \\
\hline
\end{tabular}

City of PATTERSON JUNE 2009 SUSTAINABILITY PLAN 


\begin{tabular}{|c|c|}
\hline Action & Source \\
\hline $\begin{array}{cl}\text { hours), Number of sites monitored } \\
\text { - } \quad \text { Implement program with goal to install } \\
\text { at least } 100 \text { solar electric systems on } \\
\text { residential and commercial rooftops } \\
\text { - } \quad \text { Solar PV Installations on municipal } \\
\text { buildings } \\
\text { - } \quad \text { Develop small scale wind generation } \\
\text { - } \\
\text { Research biomass energy } \\
\text { opportunities }\end{array}$ & \\
\hline $\begin{array}{l}\text { Support and develop green power purchasing. } \\
\text { Progress Indicator: Megawatt-hours of } \\
\text { renewable energy purchased } \\
\text { - Support accelerated implementation of } \\
\text { California's Renewable Portfolio } \\
\text { Standard (RPS) } \\
\text { - Evaluate Community Choice } \\
\text { Aggregation for a citywide power } \\
\text { purchasing pool }\end{array}$ & San Francisco Climate Action Plan \\
\hline $\begin{array}{l}\text { Clean hydroelectricity produces approximately } \\
90 \% \text { of City Light's power. Purchase offsets for } \\
\text { the remaining emissions, spending about } \$ 2 \text { per } \\
\text { customer per year to meet this commitment. }\end{array}$ & Seattle Climate Action Plan \\
\hline $33 \%$ renewable energy by 2020 & Burbank Sustainability Action Plan \\
\hline $\begin{array}{l}\text { Generate } 20 \% \text { of total power from clean } \\
\text { sources by } 2010\end{array}$ & Los Angeles Climate Action Plan \\
\hline $\begin{array}{l}\text { For } 2012 \text {, increase the purchase of renewable } \\
\text { energy to meet } 10 \% \text { of the City's operations } \\
\text { annual electricity energy usage. }\end{array}$ & Sacramento Implementation Plan \\
\hline $\begin{array}{l}\text { Pasadena Water \& Power offers } \\
\text { environmentally friendly "green power" to } \\
\text { customers. Currently, } 100 \% \text { of PWP's green } \\
\text { power comes from wind sources and is } \\
\text { available for an extra energy charge. Customers } \\
\text { can choose from three different options at } \\
\text { incremental additional costs. }\end{array}$ & Pasadena Green City Action Plan \\
\hline $\begin{array}{l}\text { Significantly reduce the use of fossil fuels, } \\
\text { improve the availability of locally and regionally } \\
\text { produced renewable energy, and replace or } \\
\text { renovate obsolete energy or resource inefficient } \\
\text { infrastructure (buildings, facilities, systems, } \\
\text { etc.). }\end{array}$ & Sacramento Implementation Plan \\
\hline $\begin{array}{l}\text { Conduct a feasibility study with financing } \\
\text { analysis for installing solar power equipment at } \\
\text { City-owned facilities (e.g. water reservoirs, } \\
\text { parking structures) and explore the inclusion of } \\
\text { public school buildings. }\end{array}$ & Burbank Sustainability Action Plan \\
\hline $\begin{array}{l}\text { Provide financial assistance to residents and } \\
\text { businesses to install photovoltaic systems that } \\
\text { connect to the utility. }\end{array}$ & Burbank Sustainability Action Plan \\
\hline $\begin{array}{l}\text { Require all future City constructed buildings at } \\
\text { usable sf of } 7500 \text { sf or more to have a solar } \\
\text { system design considered during the planning } \\
\text { phase, unless an exemption is identified and } \\
\text { approved by Council. }\end{array}$ & Fresno Green \\
\hline $\begin{array}{l}\text { Install solar heating for all City-owned swimming } \\
\text { pools. }\end{array}$ & Los Angeles Climate Action Plan \\
\hline $\begin{array}{l}\text { Let contracts for power imports from coal-fired } \\
\text { plants expire. }\end{array}$ & Los Angeles Climate Action Plan \\
\hline
\end{tabular}




\begin{tabular}{|l|l|}
\hline \multicolumn{1}{|c|}{ Action } & \multicolumn{1}{c|}{ Source } \\
\hline $\begin{array}{l}\text { Increase use of biogas for natural gas-fired } \\
\text { power plants. }\end{array}$ & Los Angeles Climate Action Plan \\
\hline $\begin{array}{l}\text { Indicator: Percent of citywide energy use from } \\
\text { renewable and more efficient sources } \\
\text { Target: By 2010, 25\% of all electricity use } \\
\text { should come from renewable sources }\end{array}$ & $\begin{array}{l}\text { Santa Monica Sustainable City } \\
\text { Plan }\end{array}$ \\
\hline
\end{tabular}

\section{ENERGY CONSERVATION / DEMAND REDUCTION}

Conservation saves residents and businesses money and reduces the need for new energy infrastructure such as power plants and transmission lines. Building energy efficient homes is far more cost-effective than remodeling later, but there are many measures that can be taken for existing structures. Compact fluorescent light bulbs (CFLs) are 75\% more efficient than incandescent bulbs and last much longer (Seattle CAP p.36). According to the EPA, if every U.S. household replaced one bulb with a CFL, it would cut the climate pollution of a million cars (Seattle CAP p.36). As mentioned in the Los Angeles Climate Action Plan (2007), the cleanest and least expensive kilowatt-hour of electricity is the one that does not have to be produced (p.20).

\begin{tabular}{|c|c|}
\hline Action & Source \\
\hline $\begin{array}{l}\text { Meet all new demand through conservation and } \\
\text { renewable energy sources }\end{array}$ & Seattle Climate Action Plan \\
\hline $\begin{array}{l}\text { Reduce the City's peak electrical load by } 10 \% \\
\text { through energy efficiency, shifting the timing of } \\
\text { energy demands, and conservation measures } \\
\text { by } 2012 \text {. }\end{array}$ & Fresno Green \\
\hline $\begin{array}{l}\text { For } 2012 \text {, reduce energy consumption } \\
\text { (electricity, natural gas) of City facilities on a unit } \\
\text { basis to } 10 \% \text { less than the baseline year of } \\
2005 \text {. }\end{array}$ & Sacramento Implementation Plan \\
\hline $\begin{array}{l}\text { By } 2030 \text {, energy consumption (electricity, } \\
\text { natural gas, motor fuels) of City facilities on a } \\
\text { unit basis will be } 25 \% \text { less than the baseline } \\
\text { year of } 2005 \text {. }\end{array}$ & Sacramento Implementation Plan \\
\hline $\begin{array}{l}\text { Progress will be measured by: Tracking per } \\
\text { capita residential energy use (both gas and } \\
\text { electric) }\end{array}$ & Seattle Climate Action Plan \\
\hline $\begin{array}{l}\text { Indicator: Total citywide energy use (also report } \\
\text { per capita and by sector) } \\
\text { Target: Pending completion of Greenhouse Gas } \\
\text { Emission (GHG) Inventory and GHG Reduction } \\
\text { Strategy }\end{array}$ & $\begin{array}{l}\text { Santa Monica Sustainable City } \\
\text { Plan }\end{array}$ \\
\hline $\begin{array}{l}\text { Develop a "green practices" ordinance for all } \\
\text { applicable projects to achieve } 10 \% \text { energy } \\
\text { efficiency over baseline - Title } 24 \text { requirements. }\end{array}$ & Burbank Sustainability Action Plan \\
\hline $\begin{array}{l}\text { New homes, remodels or additions greater than } \\
1,500 \text { sf must exceed Title } 24 \text { energy standards } \\
\text { by at least } 15 \%\end{array}$ & $\begin{array}{l}\text { Marin County July 3, } 2008 \text { Building } \\
\text { Code Amendment }\end{array}$ \\
\hline $\begin{array}{l}\text { Make improvements to the residential energy } \\
\text { code. }\end{array}$ & Seattle Climate Action Plan \\
\hline $\begin{array}{l}\text { The City shall incorporate energy conservation } \\
\text { measures into conditions of approval for new } \\
\text { development projects. }\end{array}$ & $\begin{array}{l}\text { Grand Terrace Sustainable } \\
\text { Development Element }\end{array}$ \\
\hline
\end{tabular}




\begin{tabular}{|c|c|}
\hline Action & Source \\
\hline $\begin{array}{l}\text { The City shall conduct an energy audit of all City } \\
\text { facilities and implement energy conservation } \\
\text { measures as appropriate. }\end{array}$ & $\begin{array}{l}\text { Grand Terrace Sustainable } \\
\text { Development Element }\end{array}$ \\
\hline $\begin{array}{l}\text { Identify the least energy efficient buildings, } \\
\text { reduce peak load, and match electrical load to } \\
\text { intermittent renewably energy such as wind. }\end{array}$ & Burbank Sustainability Action Plan \\
\hline $\begin{array}{l}\text { Add a weatherization/energy conservation } \\
\text { component to all City renovation and repair } \\
\text { programs. Develop and implement homeowner } \\
\text { weatherization program to include low-income } \\
\text { residents, including seniors, in insulating their } \\
\text { homes. }\end{array}$ & Fresno Green \\
\hline Weatherization program for gas heated homes & Seattle Climate Action Plan \\
\hline $\begin{array}{l}\text { Upgrade plants and facilities with the latest } \\
\text { technology to increase efficiency. }\end{array}$ & Los Angeles Climate Action Plan \\
\hline $\begin{array}{l}\text { Improve energy efficiency at drinking water } \\
\text { treatment and distribution facilities. }\end{array}$ & Los Angeles Climate Action Plan \\
\hline $\begin{array}{l}\text { Maximize energy efficiency of wastewater } \\
\text { treatment equipment. }\end{array}$ & Los Angeles Climate Action Plan \\
\hline $\begin{array}{l}\text { Complete energy efficiency retrofits in all City- } \\
\text { owned buildings to meet a } 20 \% \text { or more } \\
\text { reduction in energy consumption. }\end{array}$ & Los Angeles Climate Action Plan \\
\hline $\begin{array}{l}\text { Conducting a feasibility study for installing } \\
\text { devices on municipal and private buildings that } \\
\text { reduce the power required to operate } \\
\text { equipment and for shifting the equipment usage } \\
\text { to off-peak. }\end{array}$ & Pasadena Green City Action Plan \\
\hline $\begin{array}{l}\text { Seasonal "time of use" billing rate that offers } \\
\text { lower rates for electric usage during off-peak } \\
\text { hours than during peak hours. Other possible } \\
\text { rates to consider include tiered energy rates. }\end{array}$ & $\begin{array}{l}\text { Burbank Sustainability Action Plan } \\
\text { Pasadena Green City Action Plan }\end{array}$ \\
\hline $\begin{array}{l}\text { Allow individual energy users to easily access } \\
\text { consumption information and modify as } \\
\text { appropriate. }\end{array}$ & Burbank Sustainability Action Plan \\
\hline $\begin{array}{l}\text { Replacing all incandescent traffic signal lights } \\
\text { with energy-efficient Light-Emitting Diode (LED) } \\
\text { lamps. }\end{array}$ & $\begin{array}{l}\text { Burbank Sustainability Action Plan } \\
\text { Grand Terrace Sustainable } \\
\text { Development Element } \\
\text { Pasadena Green City Action Plan }\end{array}$ \\
\hline $\begin{array}{l}\text { Requiring energy efficient lighting (compact } \\
\text { fluorescents) for exterior lighting or regular lights } \\
\text { with daylight and motion sensors. }\end{array}$ & Seattle Climate Action Plan \\
\hline $\begin{array}{l}\text { Requiring linear fluorescent lights to be high } \\
\text { efficiency fluorescent fixtures (T-8s). }\end{array}$ & Seattle Climate Action Plan \\
\hline $\begin{array}{l}\text { Purchase and use of super-efficient " } 80 \text {-plus" } \\
\text { computers and servers. }\end{array}$ & Seattle Climate Action Plan \\
\hline
\end{tabular}

\section{OUTREACH \& AWARENESS}

To promote energy efficiency, cities should conduct outreach to educate and motivate the community to make small changes in their personal behavior. Public involvement is crucial to the implementation of measures helping to achieve sustainability. The actions of City employees, residents, and commercial $\&$ industrial businesses to reduce energy use will ultimately improve public health, safety, and welfare. 


\begin{tabular}{|c|c|c|}
\hline & Action & Source \\
\hline $\begin{array}{l}\text { Increase incenti } \\
\text { technical assist } \\
\text { Municipal buildir } \\
\text { Progress Indica } \\
\text { (kilowatts) and } \\
\text { therms), Increas } \\
\text { Number of staff } \\
\text { integrated into s } \\
\text { Develo } \\
\text { Progra } \\
\text { o }\end{array}$ & $\begin{array}{l}\text { es, direct installation and } \\
\text { hce (Residential, Commercial, } \\
\text { gs). } \\
\text { rs: Decreased demand } \\
\text { lergy use (kilowatt-hours, } \\
\text { d program participation rates, } \\
\text { rained, Energy efficiency is } \\
\text { andard operating procedures } \\
\text { Residential Efficiency } \\
\text { Encourage consumers to } \\
\text { choose the most efficient } \\
\text { appliances } \\
\text { Encourage early replacement } \\
\text { of old, inefficient appliances } \\
\text { with new, more efficient ones } \\
\text { Focus on water heaters, } \\
\text { furnaces, refrigerators, } \\
\text { washing machines, and } \\
\text { electric heating and natural } \\
\text { gas appliances } \\
\text { Target porch lights, table } \\
\text { lamps, and torchieres for } \\
\text { conversion to compact } \\
\text { fluorescent lamps (CFLs) } \\
\text { Weatherization and building } \\
\text { testing services to reduce } \\
\text { energy "leaks" } \\
\text { Refrigerator bulk purchasing } \\
\text { programs targeted to } \\
\text { multifamily building owners } \\
\text { lents }\end{array}$ & $\begin{array}{l}\text { San Francisco } \\
\text { Climate Action Plan }\end{array}$ \\
\hline \multicolumn{2}{|c|}{$\begin{array}{l}\text { Expand education and outreach. } \\
\text { Progress Indicators: Number of website hits and } \\
\text { hotline contacts, Number of participants trained } \\
\text { - Develop local outreach program } \\
\text { o Complement state- } \\
\text { administered Flex Your Power } \\
\text { campaign } \\
\text { o Partner with schools, } \\
\text { neighborhood organizations, } \\
\text { California Energy } \\
\text { Commission, and PG\&E } \\
\text { - Provide energy efficiency training } \\
\text { classes for designers, contractors, and } \\
\text { building operators }\end{array}$} & $\begin{array}{l}\text { San Francisco } \\
\text { Climate Action Plan }\end{array}$ \\
\hline \multicolumn{2}{|c|}{$\begin{array}{l}\text { The City shall acquire public education } \\
\text { materials on energy conservation and make } \\
\text { them available at City Hall and public functions. }\end{array}$} & $\begin{array}{l}\text { Grand Terrace Sustainable } \\
\text { Development Element }\end{array}$ \\
\hline \multicolumn{2}{|c|}{$\begin{array}{l}\text { Climate protection action-awareness campaign } \\
\text { that promotes energy conservation for both } \\
\text { natural gas and electricity for all users: homes, } \\
\text { businesses, and public institutions. }\end{array}$} & Seattle Climate Action Plan \\
\hline \multirow{2}{*}{\multicolumn{2}{|c|}{$\begin{array}{l}\text { Targeted technical assistance, incentives, } \\
\text { promotion of utility conservation programs. } \\
\text { Variety of financial incentives and rebates to }\end{array}$}} & Seattle Climate Action Plan \\
\hline & & Los Angeles Climate Action Plan \\
\hline
\end{tabular}




\begin{tabular}{|c|c|}
\hline Action & Source \\
\hline \multicolumn{2}{|l|}{$\begin{array}{l}\text { residential, commercial, and industrial } \\
\text { customers who purchase energy efficient } \\
\text { appliances or install other energy saving } \\
\text { devices. }\end{array}$} \\
\hline $\begin{array}{l}\text { Provide up to } 100 \text { solar water heaters to } \\
\text { qualified low-income owner occupied } \\
\text { households through loans over a five-year } \\
\text { period starting in } 2008 \text {. }\end{array}$ & Fresno Green \\
\hline $\begin{array}{l}\text { Customer rebates for energy efficient } \\
\text { appliances, windows, lighting, and heating and } \\
\text { cooling systems. }\end{array}$ & Los Angeles Climate Action Plan \\
\hline $\begin{array}{l}\text { Distribute two compact fluorescent light (CFL) } \\
\text { bulbs to each household. }\end{array}$ & Los Angeles Climate Action Plan \\
\hline CFL Bulb Exchange program & Sacramento Implementation Plan \\
\hline $\begin{array}{l}\text { The City shall work with Southern California } \\
\text { Edison to promote energy conservation at } \\
\text { residences and businesses. }\end{array}$ & $\begin{array}{l}\text { Grand Terrace Sustainable } \\
\text { Development Element }\end{array}$ \\
\hline $\begin{array}{l}\text { Work with PG\&E to improve and increase City- } \\
\text { wide energy conservation programs. }\end{array}$ & Fresno Green \\
\hline $\begin{array}{l}\text { Turn down, turn off, and unplug. Set } \\
\text { thermostats at } 68 \text { degrees when you're home } \\
\text { and } 55 \text { or lower when you're away or at night. } \\
\text { Turn off lights in empty rooms and unplug } \\
\text { electronics and cell phone chargers that aren't } \\
\text { in use. }\end{array}$ & Seattle Climate Action Plan \\
\hline $\begin{array}{l}\text { Install an efficient furnace. Older gas furnaces } \\
\text { and boilers waste energy. Modern systems can } \\
\text { be as high as } 97 \% \text { efficient, meaning the energy } \\
\text { you pay for actually heats your home. An } \\
\text { Energy Star brand furnace can save you up to } \\
40 \% \text { on heating bills. }\end{array}$ & Seattle Climate Action Plan \\
\hline $\begin{array}{l}\text { Use a push or electric mower. Going manual or } \\
\text { electric is cleaner and quieter. }\end{array}$ & Seattle Climate Action Plan \\
\hline $\begin{array}{l}\text { Tighten up that fireplace. Wood-burning } \\
\text { fireplaces can be a big energy drain, sucking } \\
\text { heating dollars up the chimney. Energy-saving } \\
\text { options include low-cost removable flue sealers } \\
\text { to fireplace doors or a new high-efficiency gas } \\
\text { insert. }\end{array}$ & Seattle Climate Action Plan \\
\hline $\begin{array}{l}\text { Insulate basement walls and attics to reduce } \\
\text { your energy bill by as much as } 30 \% \text {. Plug leaks } \\
\text { around doors, windows, attic hatches, and in } \\
\text { walls. }\end{array}$ & Seattle Climate Action Plan \\
\hline $\begin{array}{l}\text { Set the fridge at } 35 \text { to } 38 \text { degrees and the } \\
\text { freezer at zero for maximum efficiency. Clean } \\
\text { coils regularly. Keep the rubber door seals } \\
\text { clean and tight. Keep the fridge and freezer } \\
\text { away from heat sources. }\end{array}$ & Seattle Climate Action Plan \\
\hline Use motion sensors for lighting. & Seattle Climate Action Plan \\
\hline
\end{tabular}

\section{WASTE REDUCTION \& RECYCLING}

Consumption reduction is the ultimate goal, but before such drastic behavioral change becomes the norm, it is necessary to reduce the amount of solid waste taken to the landfill, which reduces methane (type of GHG) emissions, leads to fewer garbage truck trips to the landfill (reduced GHGs), 
and decreases the amount of land needed to accommodate our trash. Recycling is an essential (and easy) way to achieve waste reduction.

\section{SOURCE REDUCTION}

The following Actions are some of the best goals and strategies to reduce the amount of solid waste taken to the landfill.

\begin{tabular}{|c|c|}
\hline Action & Source \\
\hline $\begin{array}{l}\text { For } 2012 \text {, achieve } 60-65 \% \text { total diversion from } \\
\text { waste stream. }\end{array}$ & Sacramento Implementation Plan \\
\hline $\begin{array}{l}\text { Achieve } 75 \% \text { diversion from landfills by } 2012 \\
\text { and zero waste to landfills by } 2025 \text {. }\end{array}$ & Fresno Green \\
\hline Zero waste goal. & $\begin{array}{l}\text { Boulder County Sustainability } \\
\text { Element } \\
\text { Fresno Green } \\
\text { Los Angeles Climate Action Plan } \\
\text { Santa Monica Sustainable City } \\
\text { Plan }\end{array}$ \\
\hline $\begin{array}{l}\text { Promote source reduction, reuse, and other } \\
\text { waste reduction. } \\
\text { Progress Indicator: Increased tons of waste } \\
\text { diverted from landfill }\end{array}$ & $\begin{array}{l}\text { San Francisco } \\
\text { Climate Action Plan }\end{array}$ \\
\hline $\begin{array}{l}\text { Indicators: Total citywide solid waste } \\
\text { generation. } \\
\text { Targets: Generation: Do not exceed year } 2000 \\
\text { levels by } 2010 \text {. Diversion: Increase amount } \\
\text { diverted to } 70 \% \text { of total by } 2010 \text {. }\end{array}$ & $\begin{array}{l}\text { Santa Monica Sustainable City } \\
\text { Plan }\end{array}$ \\
\hline $\begin{array}{l}\text { Restrict yard trimmings and other easily } \\
\text { recyclable materials from disposal at the City } \\
\text { landfill. }\end{array}$ & Burbank Sustainability Action Plan \\
\hline $\begin{array}{l}\text { Reduce persistent, plastic disposables. } \\
\text { Consider local bans on plastic peanuts and } \\
\text { expanded polystyrene disposables. }\end{array}$ & Burbank Sustainability Action Plan \\
\hline $\begin{array}{l}\text { The City shall reduce the use of disposable } \\
\text { products at all City facilities. }\end{array}$ & $\begin{array}{l}\text { Grand Terrace Sustainable } \\
\text { Development Element }\end{array}$ \\
\hline $\begin{array}{l}\text { The City will work with local businesses in an } \\
\text { effort to reduce the use of disposable shopping } \\
\text { bags. }\end{array}$ & $\begin{array}{l}\text { Grand Terrace Sustainable } \\
\text { Development Element }\end{array}$ \\
\hline $\begin{array}{l}\text { Reduce use of plastic shopping bags by local } \\
\text { retailers within the City by } 2010 \text {. }\end{array}$ & Fresno Green \\
\hline $\begin{array}{l}\text { Banning recyclable paper and cardboard in } \\
\text { commercial garbage. }\end{array}$ & Seattle Climate Action Plan \\
\hline $\begin{array}{l}\text { Banning recyclable paper, cardboard and glass, } \\
\text { metal and plastic bottles in household garbage. }\end{array}$ & Seattle Climate Action Plan \\
\hline $\begin{array}{l}\text { Reduce use and sale of non-rechargeable } \\
\text { batteries within the City by } 2010 \text {. }\end{array}$ & Fresno Green \\
\hline $\begin{array}{l}\text { Reduce use and sale of incandescent bulbs } \\
\text { within the City by } 2010 \text {. }\end{array}$ & Fresno Green \\
\hline $\begin{array}{l}\text { Providing convenient curbside or on-site } \\
\text { recycling collection to households as part of } \\
\text { their solid waste collection services at no } \\
\text { additional charge. }\end{array}$ & Seattle Climate Action Plan \\
\hline $\begin{array}{l}\text { Providing convenient curbside collection of yard } \\
\text { debris and food waste to households for a } \\
\text { modest fee. }\end{array}$ & Seattle Climate Action Plan \\
\hline $\begin{array}{l}\text { Pay-as-you-throw program (since 1999). Cost } \\
\text { for curbside collection is based on how much is }\end{array}$ & Pasadena Green City Action Plan \\
\hline
\end{tabular}




\begin{tabular}{|l|l|}
\multicolumn{1}{|c|}{ Action } & \multicolumn{1}{c|}{ Source } \\
\hline $\begin{array}{l}\text { recycled and how much is thrown away. The } \\
\text { more you recycle, the less you pay. }\end{array}$ & \\
\hline Setting volume-based garbage collection fees. & Seattle Climate Action Plan \\
\hline $\begin{array}{l}\text { The City is developing facilities that will convert } \\
\text { refuse to energy without incineration. }\end{array}$ & Los Angeles Climate Action Plan \\
\hline $\begin{array}{l}\text { All City facilities which previously were provided } \\
\text { with private vendor water deliveries are required } \\
\text { to use potable water. In the long-term, the City } \\
\text { should experience a substantial cost-savings; } \\
\text { fewer resources devoted for the production of } \\
\text { plastic water containers; and less global } \\
\text { greenhouse gas emitted through the container } \\
\text { production. Each delivery run reduction helps to } \\
\text { reduce traffic congestion and improve air } \\
\text { quality. }\end{array}$ & \\
\hline
\end{tabular}

\section{RECYCLING \& COMPOSTING}

Recycling is an easy way to reduce the amount of solid waste going to the landfill, providing jobs for the local economy, while useful in providing raw materials for manufacturing companies. Composting is an effective way of re-using food waste in the garden or at the very least, minimizing the amount taken to the landfill.

\begin{tabular}{|c|c|}
\hline Action & Source \\
\hline $\begin{array}{l}\text { Increase residential recycling and composting. } \\
\text { Progress Indicator: Tons of waste diverted from } \\
\text { landfill } \\
\text { - Expand recycling and composting } \\
\text { programs } \\
\text { o } \quad \text { Fantastic 3: blue for } \\
\text { commingled recyclables - all } \\
\text { paper, cardboard, bottles, and } \\
\text { cans; green for all } \\
\text { compostable food scraps, } \\
\text { yard trimmings, wooden } \\
\text { crates, animal bedding, and } \\
\text { soiled paper; and black for } \\
\text { any remaining refuse. Also 2- } \\
\text { gallon kitchen pail to help } \\
\text { separate and collect food } \\
\text { scraps. }\end{array}$ & $\begin{array}{l}\text { San Francisco } \\
\text { Climate Action Plan }\end{array}$ \\
\hline $\begin{array}{l}\text { Convert from three-bin system to single-stream } \\
\text { recycling. }\end{array}$ & Sacramento Implementation Plan \\
\hline $\begin{array}{l}\text { Support alternate collection methods for } \\
\text { recyclable materials. } \\
\text { Progress Indicator: Tons of waste diverted from } \\
\text { landfill } \\
\text { - Increase metals recycling } \\
\text { - Support community drop-off, buy-back, } \\
\text { and collection } \\
\text { - Support recovery by material handlers }\end{array}$ & $\begin{array}{l}\text { San Francisco } \\
\text { Climate Action Plan }\end{array}$ \\
\hline $\begin{array}{l}\text { Expand municipal programs. } \\
\text { Progress Indicator: Increased tons of waste } \\
\text { diverted from landfill } \\
\text { • Expand recycling in City facilities }\end{array}$ & $\begin{array}{l}\text { San Francisco } \\
\text { Climate Action Plan }\end{array}$ \\
\hline
\end{tabular}




\begin{tabular}{|c|c|}
\hline Action & Source \\
\hline Recycle $70 \%$ of trash by 2015 . & Los Angeles Climate Action Plan \\
\hline $\begin{array}{l}\text { Mandate a minimum recycling rate for residents } \\
\text { and businesses. Increase public education, } \\
\text { outreach, awards, and recognition in advance of } \\
\text { the implementation of the mandatory } \\
\text { requirement. }\end{array}$ & Burbank Sustainability Action Plan \\
\hline $\begin{array}{l}\text { Continue and increase residential backyard } \\
\text { composting programs, including grass cycling, } \\
\text { mulching, and zero waste yard care. Promote } \\
\text { landscape educational programs addressing } \\
\text { energy and water conservation, waste } \\
\text { reduction, and organic food production and } \\
\text { consumption. }\end{array}$ & Burbank Sustainability Action Plan \\
\hline $\begin{array}{l}\text { Increase commercial recycling and composting. } \\
\text { Progress Indicator: Tons of waste diverted from } \\
\text { landfill }\end{array}$ & $\begin{array}{l}\text { San Francisco } \\
\text { Climate Action Plan }\end{array}$ \\
\hline $\begin{array}{l}\text { Expanding recycling to multifamily dwellings, } \\
\text { commercial establishments, and restaurants. }\end{array}$ & Los Angeles Climate Action Plan \\
\hline $\begin{array}{l}\text { Ensure that all new multi-family and commercial } \\
\text { buildings not only provide adequate space for } \\
\text { both refuse and recycling containers, but also } \\
\text { implement a recycling program and/or provide } \\
\text { proof that a minimum percentage of waste is } \\
\text { taken to a materials recovery facility (MRF) to } \\
\text { be recycled. }\end{array}$ & Burbank Sustainability Action Plan \\
\hline $\begin{array}{l}\text { Request a plan from franchises outlining } \\
\text { strategies to increase commercial recycling as a } \\
\text { condition of license renewal. }\end{array}$ & Pasadena Green City Action Plan \\
\hline $\begin{array}{l}\text { Implement a Business Recycling Ordinance with } \\
\text { a target of } 30 \% \text { diversion by commercial waste } \\
\text { generators. }\end{array}$ & Sacramento Implementation Plan \\
\hline $\begin{array}{l}\text { Require a plan from each private refuse hauler } \\
\text { to increase commercial recycling as a condition } \\
\text { of the hauler's license renewal. Require haulers } \\
\text { to achieve a minimum recycling rate, such as } \\
\text { the state-mandated } 50 \% \text { presently required of } \\
\text { cities. }\end{array}$ & Burbank Sustainability Action Plan \\
\hline $\begin{array}{l}\text { Implement a Food Waste Recycling Program for } \\
\text { residences, restaurants, and other businesses. }\end{array}$ & $\begin{array}{l}\text { Fresno Green } \\
\text { Burbank Sustainability Action Plan } \\
\text { Pasadena Green City Action Plan }\end{array}$ \\
\hline $\begin{array}{l}\text { Permanent electronic waste collection center in } \\
\text { the City. }\end{array}$ & $\begin{array}{l}\text { Burbank Sustainability Action Plan } \\
\text { Pasadena Green City Action Plan }\end{array}$ \\
\hline $\begin{array}{l}\text { Within renewable limits, encourage the use of } \\
\text { local, non-polluting, renewable and recycled } \\
\text { resources (material resources). }\end{array}$ & $\begin{array}{l}\text { Santa Monica Sustainable City } \\
\text { Plan }\end{array}$ \\
\hline
\end{tabular}

\section{CONSTRUCTION \& DEMOLITION RECYCLING}

Recycling construction and demolition waste is an easy way to reduce the amount of solid waste going to the landfill, providing jobs for the local economy, while useful in providing raw materials for other construction projects and manufacturing companies. Many cities have a mandatory ordinance requiring a certain percentage to be recycled. The following are a few of the cities that have a Construction \& Demolition Recycling Ordinance: Burbank, Davis, Oakland, Palo Alto, Sacramento, San Francisco, San Jose, Santa Monica, Santa Rosa, and Willits. The following table shows what some cities are doing in their Plans. 


\begin{tabular}{|c|c|}
\hline Action & Source \\
\hline $\begin{array}{l}\text { Expand construction and demolition debris } \\
\text { recycling. } \\
\text { Progress Indicator: Tons of waste diverted from } \\
\text { landfill }\end{array}$ & $\begin{array}{l}\text { San Francisco } \\
\text { Climate Action Plan }\end{array}$ \\
\hline $\begin{array}{l}\text { Mandatory Construction and Demolition (C\&D) } \\
\text { Ordinance }\end{array}$ & $\begin{array}{l}\text { Burbank Sustainability Action Plan } \\
\text { Fresno Green } \\
\text { Grand Terrace Sustainable } \\
\text { Development Element } \\
\text { Pasadena Green City Action Plan }\end{array}$ \\
\hline $\begin{array}{l}\text { Require new construction projects to divert } 60 \% \\
\text { of their waste away from landfills. }\end{array}$ & Pasadena Green City Action Plan \\
\hline $\begin{array}{l}\text { Mandatory Construction and Demolition (C\&D) } \\
\text { Ordinance requires } 50 \% \text { recycling of } \\
\text { construction materials. Review and increase the } \\
\text { minimum recycling rate periodically as C\&D } \\
\text { processes and markets improve. Assist } \\
\text { contractors and buildings in locating C\&D } \\
\text { materials recovery facilities (MRFs), materials } \\
\text { exchange opportunities, and other reuse and } \\
\text { recycling sources. }\end{array}$ & Burbank Sustainability Action Plan \\
\hline
\end{tabular}

\section{SUSTAINABLE PURCHASING / PRODUCT STEWARDSHIP}

The City has significant influence on the market through purchasing, procurement, and contracting. As mentioned in the Los Angeles Climate Action Plan (2007), the City "has the power to provide leadership, stimulate market demand, model innovative and profitable green businesses, promote private investment, create a business-friendly regulatory environment for green companies, and invest in workforce development programs that facilitate growth of the green economy" (p.11-12).

\begin{tabular}{|l|l|}
\hline \multicolumn{1}{|c|}{ Action } & Source \\
\hline $\begin{array}{l}\text { Decrease consumption of non-local, non- } \\
\text { renewable, non-recyclable and non-recycled } \\
\text { materials, water, and energy and fuels. The City } \\
\text { should take a leadership role in encouraging } \\
\text { sustainable procurement and extended }\end{array}$ & $\begin{array}{l}\text { Santa Monica Sustainable City } \\
\text { Plan }\end{array}$ \\
producer responsibility. & \\
\hline $\begin{array}{l}\text { Support statewide and national product } \\
\text { stewardship policies and programs that } \\
\text { encourage manufacturers to design safe, long } \\
\text { lasting, repairable and recyclable products and } \\
\text { to take back products at the end of their useful } \\
\text { life. }\end{array}$ & Burbank Sustainability Action Plan \\
\hline $\begin{array}{l}\text { Support Producer Responsibility, where product } \\
\text { manufacturers are responsible for the final } \\
\text { disposal of any toxic products produced, } \\
\text { through continued support of the California }\end{array}$ & \\
Product Stewardship Council. & Fresno Green \\
\hline $\begin{array}{l}\text { Developing practices for cleaning, maintenance, } \\
\text { and operations of municipal facilities to advance } \\
\text { sustainability and eliminate the use of toxins. } \\
\text { Maintenance staff will be trained, and } \\
\text { purchasing staff will be required to purchase }\end{array}$ & Pasadena Green City Action Plan \\
\hline
\end{tabular}




\begin{tabular}{|c|c|}
\hline Action & Source \\
\hline environmentally preferable cleaning products. & \\
\hline $\begin{array}{l}\text { Develop an environmentally friendly purchasing } \\
\text { policy addressing "green" services and products } \\
\text { (repairable, long life, recycled content, } \\
\text { sustainability-produced, non-toxic). Begin with a } \\
\text { City Administrative Procedure requiring the } \\
\text { purchase of "green" products and the } \\
\text { minimization of the use of disposables such as } \\
\text { Styrofoam cups, plates, and plastic ware. }\end{array}$ & Burbank Sustainability Action Plan \\
\hline $\begin{array}{l}\text { The City shall develop and implement a policy } \\
\text { for the purchase of "green" products whenever } \\
\text { possible. }\end{array}$ & $\begin{array}{l}\text { Grand Terrace Sustainable } \\
\text { Development Element }\end{array}$ \\
\hline
\end{tabular}

\section{OUTREACH \& AWARENESS}

To promote waste reduction \& recycling, cities should conduct outreach to educate and motivate the community to make small changes in their personal behavior. Public involvement is crucial to the implementation of measures helping to achieve sustainability. The actions of City employees, residents, and commercial \& industrial businesses to reduce waste and recycle more will ultimately improve public health, safety, and welfare.

\begin{tabular}{|l|l|}
\hline \multicolumn{1}{|c|}{ Action } & \multicolumn{1}{|c|}{ Source } \\
\hline $\begin{array}{l}\text { Encouraging waste minimization and recycling } \\
\text { through education and outreach. }\end{array}$ & Seattle Climate Action Plan \\
\hline $\begin{array}{l}\text { Develop and implement public education } \\
\text { programs for waste reduction, reuse, and } \\
\text { recycling. }\end{array}$ & $\begin{array}{l}\text { Grand Terrace Sustainable } \\
\text { Development Element }\end{array}$ \\
\hline $\begin{array}{l}\text { Educate those who live, work, and interact in } \\
\text { our community to emulate sustainable natural } \\
\text { cycles, where all discarded materials are } \\
\text { resources for others to use beginning in 2008. }\end{array}$ & Fresno Green \\
\hline Composting workshops. & Pasadena Green City Action Plan \\
\hline $\begin{array}{l}\text { Conduct a reuse campaign for both businesses } \\
\text { and residents establishing partnerships with and } \\
\text { promoting thrift shops and reuse stores. } \\
\text { Establish and/or promote materials exchange } \\
\text { programs and include a program to divert bulky } \\
\text { items from landfills. }\end{array}$ & Burbank Sustainability Action Plan \\
\hline $\begin{array}{l}\text { Develop an outreach plan in partnership with } \\
\text { local businesses and others to reduce the use } \\
\text { and disposal of plastic bag and food service } \\
\text { plastics. }\end{array}$ & Burbank Sustainability Action Plan \\
\hline $\begin{array}{l}\text { Work in collaboration with local grocery stores } \\
\text { and supermarkets to set a reduction target of a } \\
\text { given quantity of disposable grocery bags. }\end{array}$ & Pasadena Green City Action Plan \\
\hline \begin{tabular}{l} 
Outstanding recycler awards. \\
\hline
\end{tabular} & $\begin{array}{l}\text { Burbank Sustainability Action Plan } \\
\text { Pasadena Green City Action Plan }\end{array}$ \\
\hline
\end{tabular}

\section{WATER}

To be sustainable, a city needs to provide its residents with a clean, reliable source of water, and reduce the amount of water it consumes to be able to allow groundwater aquifers to recharge and provide water for future generations. 


\section{WATER CONSERVATION / DEMAND REDUCTION}

Water conservation can reduce wastewater treatment costs, improve air quality, and reduce GHG emissions. According to the Los Angeles Climate Action Plan (2007), "one of the most cost-effective ways to meet the future demands for water is to conserve. Water supply diversity is also important and alternative supplies, including recycled water and storm water capture, should be pursued" (p.21). Conserving water reduces energy consumption an estimated 19\% of California's total electricity demand is associated with water pumping and treatment (p.21).

\begin{tabular}{|c|c|}
\hline Action & Source \\
\hline Reduce per capita water consumption by $20 \%$. & Los Angeles Climate Action Plan \\
\hline $\begin{array}{l}\text { Reduce overall water use by } 20 \% \text { by } 2010 \text {. } \\
\text { Increase percentage of locally-obtained potable } \\
\text { water to } 70 \% \text { of total by } 2010 \text {. } \\
\text { Indicators: Total citywide water use (also report } \\
\text { per capita and by sector), Percent local vs. } \\
\text { imported }\end{array}$ & $\begin{array}{l}\text { Santa Monica Sustainable City } \\
\text { Plan }\end{array}$ \\
\hline $\begin{array}{l}\text { Continue working with the Metropolitan Water } \\
\text { District in researching, developing, and } \\
\text { implementing emerging water efficiency } \\
\text { technologies and strategies that may assist in } \\
\text { meeting the goal of reducing water consumption } \\
\text { by } 10 \% \text { by } 2015 \text {. }\end{array}$ & Burbank Sustainability Action Plan \\
\hline $\begin{array}{l}\text { The City shall incorporate water conservation } \\
\text { into the development review process. }\end{array}$ & $\begin{array}{l}\text { Grand Terrace Sustainable } \\
\text { Development Element }\end{array}$ \\
\hline $\begin{array}{l}\text { Mandate all projects to achieve a water use } \\
\text { reduction of } 20 \% \text { over baseline. }\end{array}$ & Burbank Sustainability Action Plan \\
\hline $\begin{array}{l}\text { Hold water use steady despite overall } \\
\text { population growth. }\end{array}$ & Los Angeles Climate Action Plan \\
\hline $\begin{array}{l}\text { Meet all additional demand for water resulting } \\
\text { from growth through water conservation ad } \\
\text { recycling. }\end{array}$ & Los Angeles Climate Action Plan \\
\hline $\begin{array}{l}\text { Adopt an ordinance requiring replacement of } \\
\text { inefficient plumbing fixtures (toilets, urinals, } \\
\text { shower heads, etc.) when properties change } \\
\text { ownership. }\end{array}$ & $\begin{array}{l}\text { Burbank Sustainability Action Plan } \\
\text { Pasadena Green City Action Plan }\end{array}$ \\
\hline $\begin{array}{l}\text { Continue focusing on outdoor water efficiency } \\
\text { programs, such as weather based irrigation } \\
\text { controllers and drought tolerant landscaping. } \\
\text { Conduct cost-effectiveness analysis of } \\
\text { landscape audits for large commercial } \\
\text { customers. }\end{array}$ & Burbank Sustainability Action Plan \\
\hline $\begin{array}{l}\text { Regionally appropriate vegetation - percent of } \\
\text { new or replaced, public landscaped area with } \\
\text { regionally appropriate plants }\end{array}$ & $\begin{array}{l}\text { Santa Monica Sustainable City } \\
\text { Plan }\end{array}$ \\
\hline $\begin{array}{l}\text { Incorporate water conservation into park } \\
\text { planning and design. }\end{array}$ & $\begin{array}{l}\text { Benicia Community Development } \\
\text { and Sustainability Element }\end{array}$ \\
\hline $\begin{array}{l}\text { Automated Irrigation System for parks to reduce } \\
\text { water use. }\end{array}$ & Sacramento Implementation Plan \\
\hline $\begin{array}{l}\text { Install water meters and develop a usage-based } \\
\text { fee system on all single-family residential } \\
\text { locations by } 2015 \text {. }\end{array}$ & Fresno Green \\
\hline $\begin{array}{l}\text { Identify and develop opportune locations for } \\
\text { stormwater infiltration to recharge groundwater } \\
\text { aquifers. }\end{array}$ & Los Angeles Climate Action Plan \\
\hline
\end{tabular}




\section{OUTREACH \& AWARENESS}

To conserve water, cities should conduct outreach to educate and motivate the community to make small changes in their personal behavior. Public involvement is crucial to the implementation of measures helping to achieve sustainability. The actions of City employees, residents, and commercial \& industrial businesses to conserve water will ultimately improve public health, safety, and welfare.

\begin{tabular}{|l|l|}
\hline \multicolumn{1}{|c|}{ Action } & \\
\hline $\begin{array}{l}\text { Initiate a water conservation education and } \\
\text { inspection program. }\end{array}$ & Source \\
\hline Water Meter Retrofit Project & Sacramento Implementation Plan \\
\hline $\begin{array}{l}\text { Develop and promote programs to both } \\
\text { residential and commercial customers that } \\
\text { strongly encourage the purchase and } \\
\text { installation of durable water-saving fixtures and } \\
\text { devices. }\end{array}$ & Burbank Sustainability Action Plan \\
\hline $\begin{array}{l}\text { Comprehensive showerhead and faucet aerator } \\
\text { program for all residential customers. }\end{array}$ & Seattle Climate Action Plan \\
\hline $\begin{array}{l}\text { Encourage the use of waterless urinals, high } \\
\text { efficiency toilets, and other water conserving } \\
\text { fixtures to decrease the volume of wastewater } \\
\text { for treatment. }\end{array}$ & Burbank Sustainability Action Plan \\
\hline $\begin{array}{l}\text { Regular bill inserts with conservation message. } \\
\text { Landscape workshops on native plants. }\end{array}$ & Burbank Sustainability Action Plan \\
\hline $\begin{array}{l}\text { Special editions of the community newsletter } \\
\text { devoted to water issues. }\end{array}$ & Burbank Sustainability Action Plan \\
\hline $\begin{array}{l}\text { Develop signage to place around the City } \\
\text { highlighting conservation efforts and native } \\
\text { landscape efforts. }\end{array}$ & Burbank Sustainability Action Plan \\
\hline $\begin{array}{l}\text { Conserve water. Your hot water tank is your } \\
\text { home's second largest user of energy. Set your } \\
\text { tank at 120 degrees, take shorter showers, use } \\
\text { water-efficient dishwashers and washing } \\
\text { machines, run them only when full and wash } \\
\text { clothes in cold water. You'll save money on } \\
\text { energy and water. }\end{array}$ & Seattle Climate Action Plan \\
\hline
\end{tabular}

\section{SUSTAINABLE ECONOMIC DEVELOPMENT}

The economy can be stimulated (e.g. job creation, business opportunities) by investing in solutions to combat climate change and achieve sustainability. Innovation and improvements in efficiency save consumers money, allowing them to spend it on local, environmentally-friendly goods and services, contributing to a stable economy. The Los Angeles Climate Action Plan calls for cities to "provide leadership, stimulate market demand, model innovative and profitable green businesses, promote private investment, create a business-friendly regulatory environment for green companies, and invest in workforce development programs that speed growth of the green economy" (p.5). Agricultural preservation is also a topic relevant to sustainable economic development in and around Patterson, but it will mostly be addressed in the Food Systems Planning subsection of the Public Health chapter. 


\begin{tabular}{|c|c|}
\hline Action & Source \\
\hline $\begin{array}{l}\text { Nurture a diverse, stable, local economy that } \\
\text { supports basic needs of all segments of the } \\
\text { community. }\end{array}$ & $\begin{array}{l}\text { Santa Monica Sustainable City } \\
\text { Plan }\end{array}$ \\
\hline $\begin{array}{l}\text { No single sector shall be greater than } 25 \% \text { of } \\
\text { total economic activity/output; and the top three } \\
\text { sectors shall not be greater than } 50 \% \text { of total } \\
\text { economic activity/output. }\end{array}$ & $\begin{array}{l}\text { Santa Monica Sustainable City } \\
\text { Plan }\end{array}$ \\
\hline $\begin{array}{l}\text { Attract and retain a balance of different kinds of } \\
\text { industrial uses. }\end{array}$ & $\begin{array}{l}\text { Benicia Community Development } \\
\text { and Sustainability Element }\end{array}$ \\
\hline $\begin{array}{l}\text { Increase local and regional job production, thus } \\
\text { keeping money in the regional economy. }\end{array}$ & Sacramento Implementation Plan \\
\hline $\begin{array}{l}\text { Indicator: Jobs/housing balance - ratio of the } \\
\text { number of jobs to the amount of housing } \\
\text { Target: Ratio should approach } 1\end{array}$ & $\begin{array}{l}\text { Santa Monica Sustainable City } \\
\text { Plan }\end{array}$ \\
\hline $\begin{array}{l}\text { Indicator: Jobs/housing balance - percent of } \\
\text { residents employed inside the City } \\
\text { Target: Increasing trend }\end{array}$ & $\begin{array}{l}\text { Santa Monica Sustainable City } \\
\text { Plan }\end{array}$ \\
\hline $\begin{array}{l}\text { Indicator: Local employment of City staff - } \\
\text { percent of City employees who live inside the } \\
\text { City, distance City employees travel to work }\end{array}$ & $\begin{array}{l}\text { Santa Monica Sustainable City } \\
\text { Plan }\end{array}$ \\
\hline $\begin{array}{l}\text { Prioritize the green sector in the City's overall } \\
\text { economic development and workforce } \\
\text { strategies. }\end{array}$ & Los Angeles Climate Action Plan \\
\hline $\begin{array}{l}\text { Indicator: Number of certified "green" } \\
\text { businesses } \\
\text { Targets: Increase to } 25 \text { by } 2010 \text {, and } 50 \text { by } \\
2012\end{array}$ & Marin Countywide Plan \\
\hline $\begin{array}{l}\text { Support and encourage existing green } \\
\text { enterprises in the City through a Green } \\
\text { Business Recognition program by } 2009 .\end{array}$ & Fresno Green \\
\hline $\begin{array}{l}\text { Incorporate into the City's Economic } \\
\text { Development Strategic Plan policies and } \\
\text { incentives for attracting new green businesses } \\
\text { by } 2010 \text {. }\end{array}$ & Fresno Green \\
\hline $\begin{array}{l}\text { Collaborate with local educational institutions } \\
\text { such as universities, community colleges, and } \\
\text { adult education programs to create more } \\
\text { curricula that provide City residents with the } \\
\text { skills and knowledge to create and work for } \\
\text { competitive green businesses. }\end{array}$ & Los Angeles Climate Action Plan \\
\hline $\begin{array}{l}\text { Develop targeted programs to train residents of } \\
\text { low and middle-income communities for jobs in } \\
\text { the greening economy. }\end{array}$ & Los Angeles Climate Action Plan \\
\hline $\begin{array}{l}\text { Designate and establish Air Quality } \\
\text { Empowerment Zones which produce } \\
\text { quantifiable reductions and preserve or create } \\
\text { jobs in economically disadvantaged areas by } \\
2011 .\end{array}$ & Fresno Green \\
\hline $\begin{array}{l}\text { Create environmentally beneficial jobs in low- } \\
\text { income neighborhoods by } 2015 \text {. }\end{array}$ & Fresno Green \\
\hline $\begin{array}{l}\text { Collaborate with community-based } \\
\text { organizations to develop workforce training } \\
\text { programs to ensure that residents of low-income } \\
\text { communities develop the skills to obtain living } \\
\text { wage jobs in the greening economy. }\end{array}$ & Los Angeles Climate Action Plan \\
\hline Development of a "CleanTech" zone & $\begin{array}{l}\text { Sacramento Implementation Plan, } \\
\text { City of Benicia }\end{array}$ \\
\hline Encourage and recruit green technology & Sacramento Implementation Plan \\
\hline
\end{tabular}




\begin{tabular}{|c|c|}
\hline Action & Source \\
\hline \multicolumn{2}{|l|}{ companies to locate in the City. } \\
\hline $\begin{array}{l}\text { Identify and promote locations for green } \\
\text { businesses. }\end{array}$ & Los Angeles Climate Action Plan \\
\hline $\begin{array}{l}\text { Collaborate with the private sector to offer } \\
\text { effective incentives for the growth of local green } \\
\text { businesses. }\end{array}$ & Los Angeles Climate Action Plan \\
\hline $\begin{array}{l}\text { Encourage development of a green business } \\
\text { park for new businesses where waste streams } \\
\text { are treated as resources by } 2012 \text {. }\end{array}$ & Fresno Green \\
\hline $\begin{array}{l}\text { Support a local green business council that } \\
\text { provides information exchange and promotes } \\
\text { sustainable business practices that balance } \\
\text { environment, equity, and economy. }\end{array}$ & Burbank Sustainability Action Plan \\
\hline $\begin{array}{l}\text { Leverage City policy, purchasing practices, and } \\
\text { regulation, and deepen local university } \\
\text { partnerships to promote local research, } \\
\text { development, and production of green } \\
\text { technology and products. }\end{array}$ & Los Angeles Climate Action Plan \\
\hline $\begin{array}{l}\text { Promote and support the use of local products, } \\
\text { technologies, expertise, and other locally } \\
\text { available resources. }\end{array}$ & $\begin{array}{l}\text { Boulder County Sustainability } \\
\text { Element }\end{array}$ \\
\hline Create public/private partnerships. & Sacramento Implementation Plan \\
\hline $\begin{array}{l}\text { Establish and award bid preferences to City } \\
\text { vendors and contractors that operate in a green } \\
\text { fashion. }\end{array}$ & Sacramento Implementation Plan \\
\hline $\begin{array}{l}\text { Build on existing partnerships to interest } \\
\text { business in energy efficiency measures, identify } \\
\text { ways to engage businesses in new strategies } \\
\text { and to track progress (awards program). }\end{array}$ & Sacramento Implementation Plan \\
\hline $\begin{array}{l}\text { Work with the business community on } \\
\text { opportunities to promote sustainability, such as } \\
\text { the Greenest Hotel Competition. }\end{array}$ & Sacramento Implementation Plan \\
\hline $\begin{array}{l}\text { Track economic growth with the Index for } \\
\text { Sustainable Economic Welfare or the Genuine } \\
\text { Progress Indicator (GPI) in addition to gross } \\
\text { product starting in 2009. }\end{array}$ & Fresno Green \\
\hline $\begin{array}{l}\text { Strengthen the Downtown as the City's central } \\
\text { commercial zone. }\end{array}$ & $\begin{array}{l}\text { Benicia Community Development } \\
\text { and Sustainability Element }\end{array}$ \\
\hline
\end{tabular}

\section{NATURAL Resources}

Preserving open space and maintaining a healthy urban forest (trees and vegetation) is essential to sustainability to ensure the long-term existence of humans and sensitive species. Beyond the highly-desired aesthetic value, these resources provide habitat, recreational opportunities, and carbon sequestration benefits. As mentioned in the Los Angeles Climate Action Plan (2007), "green spaces allow the City and its people to breathe, relax, play, and to find a connection to nature," while "soil and vegetation filters air pollution and absorbs $\mathrm{CO} 2$, prevents flooding and replenishes groundwater, and provides public health benefits and opportunities for recreation" (p.25).

\begin{tabular}{|l|l|}
\hline \multicolumn{1}{|c|}{ Action } & \multicolumn{1}{c|}{ Source } \\
\hline $\begin{array}{l}\text { The City shall seek to preserve open space and } \\
\text { habitat areas. }\end{array}$ & $\begin{array}{l}\text { Grand Terrace Sustainable } \\
\text { Development Element }\end{array}$ \\
\hline Select sites that are not adjacent to wetlands, & Grand Terrace Sustainable \\
\hline
\end{tabular}




\begin{tabular}{|c|c|}
\hline Action & Source \\
\hline $\begin{array}{l}\text { on prime farmland, or have sensitive species or } \\
\text { habitat present. }\end{array}$ & Development Element \\
\hline $\begin{array}{l}\text { Provide incentives for habitat restoration and } \\
\text { protection through the City's Fresno Green } \\
\text { building incentive program by } 2011 \text {. }\end{array}$ & Fresno Green \\
\hline $\begin{array}{l}\text { Strive to preserve significant areas of vegetation } \\
\text { and open space when approving development } \\
\text { projects. }\end{array}$ & $\begin{array}{l}\text { Benicia Community Development } \\
\text { and Sustainability Element }\end{array}$ \\
\hline $\begin{array}{l}\text { Restoration and management plans for natural } \\
\text { open space areas and demonstration } \\
\text { landscapes. }\end{array}$ & Sacramento Implementation Plan \\
\hline $\begin{array}{l}\text { Increase the amount of publicly accessible and } \\
\text { protected green space and riparian corridors, } \\
\text { expand the urban forest, and preserve farmland } \\
\text { and habitat resources. }\end{array}$ & Sacramento Implementation Plan \\
\hline $\begin{array}{l}\text { Protect the ecological integrity of the City's } \\
\text { primary drinking water sources (i.e. aquifers, } \\
\text { rivers, lakes, wetlands, and associated } \\
\text { ecosystems). }\end{array}$ & Fresno Green \\
\hline $\begin{array}{l}\text { Use environmentally-friendly and rapidly } \\
\text { renewable products. Use wood alternatives or } \\
\text { FSC-certified wood products. Use flooring } \\
\text { products of bamboo, cork, or eucalyptus that } \\
\text { grow rapidly. }\end{array}$ & $\begin{array}{l}\text { Grand Terrace Sustainable } \\
\text { Development Element }\end{array}$ \\
\hline $\begin{array}{l}\text { Use pervious paving materials/products that } \\
\text { filter surface runoff. }\end{array}$ & $\begin{array}{l}\text { Grand Terrace Sustainable } \\
\text { Development Element }\end{array}$ \\
\hline
\end{tabular}

\section{URBAN FORESTRY}

Preserving, protecting, and planting more trees and vegetation enhances the removal of carbon dioxide $\left(\mathrm{CO}_{2}\right)$ from the atmosphere, known as carbon sequestration.

\begin{tabular}{|l|l|}
\hline \multicolumn{1}{|c|}{ Action } & \multicolumn{1}{c|}{ Source } \\
\hline $\begin{array}{l}\text { Comprehensively assess the health and } \\
\text { condition of the City's oldest and most } \\
\text { significant trees. }\end{array}$ & Sacramento Implementation Plan \\
\hline $\begin{array}{l}\text { Continue tree planting and replacement } \\
\text { programs with a goal of adding } 1000 \text { new trees } \\
\text { annually. }\end{array}$ & Sacramento Implementation Plan \\
\hline $\begin{array}{l}\text { Begin compilation of a GIS-based database } \\
\text { (tree inventory) of all publicly owned trees. }\end{array}$ & $\begin{array}{l}\text { Burbank Sustainability Action Plan } \\
\text { Sacramento Implementation Plan }\end{array}$ \\
\hline $\begin{array}{l}\text { For 2030, achieve double the current canopy } \\
\text { cover to meet the Greenprint goal of an average } \\
\text { of 35\% canopy coverage. }\end{array}$ & Sacramento Implementation Plan \\
\hline $\begin{array}{l}\text { Plant and maintain trees in order to achieve } \\
\text { shading of at least 50\% of all hardscaped } \\
\text { parking and pedestrian surfaces by 2015. }\end{array}$ & Fresno Green \\
\hline $\begin{array}{l}\text { Work with community groups such as Tree } \\
\text { Fresno to conduct an inventory of existing } \\
\text { canopy coverage in the City and to prepare } \\
\text { adequate maintenance plans of City-owned } \\
\text { trees and landscaped medians by 2010. }\end{array}$ & Fresno Green \\
\hline $\begin{array}{l}\text { Trees for a Green LA program provides free } \\
\text { shade trees to LADWP customers to save } \\
\text { energy and improve local climates. Partnership }\end{array}$ & Los Angeles Climate Action Plan \\
\hline
\end{tabular}




\begin{tabular}{|l|l|}
\hline \multicolumn{1}{|c|}{ Action } & \multicolumn{1}{|c|}{ Source } \\
\hline $\begin{array}{l}\text { with the Million Trees LA initiative, providing } \\
\text { shade and cooling temperatures, thus reducing } \\
\text { the urban heat island effect. }\end{array}$ & \\
\hline $\begin{array}{l}\text { The City shall develop a program and seek } \\
\text { grant funds for the planting of shade trees and } \\
\text { other landscaping along all arterial highways } \\
\text { and on all municipal property. }\end{array}$ & $\begin{array}{l}\text { Grand Terrace Sustainable } \\
\text { Development Element }\end{array}$ \\
\hline
\end{tabular}

\section{Public Health}

Clearly, public health is addressed directly and indirectly in each of the focus areas for achieving sustainability in Patterson. This section specifically addresses air quality, food systems planning, and the obesity rate. While urban forestry is an important resource for carbon sequestration and improving air quality, this topic is addressed in the Natural Resources section.

\section{AIR QUALITY}

Improved air quality will reduce the number of people who suffer from asthma, respiratory illnesses, and cancer. According to the Los Angeles Climate Action Plan (2007), "pollution from cars, trucks, buses, and other mobile sources is the major contributor to the formation of smog, a health concern for residents" (p.21). Many cities are proactively reducing greenhouse gas emissions through a number of innovative strategies, thereby improving air quality.

\begin{tabular}{|c|c|}
\hline Action & Source \\
\hline $\begin{array}{l}\text { Reduce citywide total greenhouse emissions to } \\
\text { match requirements of State Assembly Bill } 32 \\
\text { by } 2012 \text {. }\end{array}$ & Fresno Green \\
\hline $\begin{array}{l}\text { By } 2024, \text { meet the federal clean air standards } \\
\text { through coordination with the California Air } \\
\text { Resources Board and San Joaquin Valley Air } \\
\text { Pollution Control District. }\end{array}$ & Fresno Green \\
\hline $\begin{array}{l}\text { Indicator: Total citywide greenhouse gas } \\
\text { emissions (also report per capita, by source, } \\
\text { and by sector) } \\
\text { Target: At least } 30 \% \text { below } 1990 \text { levels by } 2015 \\
\text { for City Operations; At least } 15 \% \text { below } 1990 \\
\text { levels by } 2015 \text { citywide }\end{array}$ & $\begin{array}{l}\text { Santa Monica Sustainable City } \\
\text { Plan }\end{array}$ \\
\hline $\begin{array}{l}\text { Annual reporting to the California Climate Action } \\
\text { Registry, a volunteer program to record and } \\
\text { monitor greenhouse gas emissions. }\end{array}$ & $\begin{array}{l}\text { Burbank Sustainability Action Plan } \\
\text { Fresno Green }\end{array}$ \\
\hline $\begin{array}{l}\text { Develop a system for accounting and auditing } \\
\text { greenhouse gas emissions. }\end{array}$ & Fresno Green \\
\hline $\begin{array}{l}\text { Focus on larger air quality contributors to } \\
\text { reduce emissions. }\end{array}$ & Fresno Green \\
\hline $\begin{array}{l}\text { Reduce motor vehicle emissions by increasing } \\
\text { transit, biking, and walking opportunities - } \\
\text { significantly improving air quality and public } \\
\text { health. }\end{array}$ & Seattle Climate Action Plan \\
\hline $\begin{array}{l}\text { City-wide automated traffic signal } \\
\text { synchronization and control system (ATSAC) to } \\
\text { reduce vehicle emissions. }\end{array}$ & $\begin{array}{l}\text { Fresno Green } \\
\text { Los Angeles Climate Action Plan }\end{array}$ \\
\hline
\end{tabular}




\begin{tabular}{|c|c|}
\hline Action & Source \\
\hline $\begin{array}{l}\text { Consider policies for alternatives to the use of } \\
\text { gasoline powered lawn mowers. }\end{array}$ & Fresno Green \\
\hline $\begin{array}{l}\text { Develop Department level action plans for } \\
\text { Healthy Air Living. }\end{array}$ & Fresno Green \\
\hline $\begin{array}{l}\text { The City shall require that development projects } \\
\text { that result in substantial air quality impacts to } \\
\text { incorporate design or operational features that } \\
\text { result in a reduction in emissions equal to } 15 \% \\
\text { from the level that would be produced by an } \\
\text { unmitigated project. }\end{array}$ & Sacramento Implementation Plan \\
\hline $\begin{array}{l}\text { The City shall review proposed development } \\
\text { projects to ensure projects incorporate feasible } \\
\text { measures that reduce emissions through project } \\
\text { design. }\end{array}$ & Sacramento Implementation Plan \\
\hline $\begin{array}{l}\text { The Department of Utilities will evaluate the } \\
\text { concept of providing voluntary carbon neutral } \\
\text { services to its customers. }\end{array}$ & Sacramento Implementation Plan \\
\hline Offer and improve carbon neutral events. & Sacramento Implementation Plan \\
\hline $\begin{array}{l}\text { For } 2012 \text {, carbon neutral services will be } \\
\text { available to all water and solid waste customers. }\end{array}$ & Sacramento Implementation Plan \\
\hline $\begin{array}{l}\text { Reduce urban heat island effect } \\
\text { Indicator: Percent of open space that is } \\
\text { permeable. Target: Upward trend }\end{array}$ & $\begin{array}{l}\text { Santa Monica Sustainable City } \\
\text { Plan }\end{array}$ \\
\hline $\begin{array}{l}\text { Reduce heat islands (parking lots). Use shade } \\
\text { trees, paving materials with a high Solar } \\
\text { Reflectance Index, and open grid paving in } \\
\text { parking lots and driveways. Maximize open } \\
\text { space areas around buildings and parking lots. }\end{array}$ & $\begin{array}{l}\text { Grand Terrace Sustainable } \\
\text { Development Element }\end{array}$ \\
\hline $\begin{array}{l}\text { Reduce heat islands (roofs). Use roofing } \\
\text { materials with a high Solar Reflectance Index to } \\
\text { reduce heat generation and energy } \\
\text { consumption. }\end{array}$ & $\begin{array}{l}\text { Grand Terrace Sustainable } \\
\text { Development Element }\end{array}$ \\
\hline $\begin{array}{l}\text { Reduce the heat island effect by planting } 1 \\
\text { million trees throughout the City and increasing } \\
\text { open space }\end{array}$ & Los Angeles Climate Action Plan \\
\hline Woodsmoke Ordinance & Marin Countywide Plan \\
\hline $\begin{array}{l}\text { Use paints, cleaning products, and fabrics with } \\
\text { Low Volatile Organic Compound (VOC) } \\
\text { production. }\end{array}$ & $\begin{array}{l}\text { Grand Terrace Sustainable } \\
\text { Development Element }\end{array}$ \\
\hline $\begin{array}{l}\text { Use of climate-friendly cement using blast- } \\
\text { furnace slag. }\end{array}$ & Seattle Climate Action Plan \\
\hline $\begin{array}{l}\text { Develop an education program to increase } \\
\text { awareness of air quality improvement options by } \\
2010 \text {. }\end{array}$ & Fresno Green \\
\hline
\end{tabular}

\section{FOOD SYSTEMS PLANNING}

Cities work with County officials to promote the adoption of sustainable agriculture practices, community gardens, and the purchase of fresh, local, organic food options. When done successfully, food systems planning can improve residents' health as well as the local economy, all while reducing greenhouse gas emissions when produce is no longer transported from thousands of miles away. 


\begin{tabular}{|c|c|}
\hline Action & Source \\
\hline Develop a food systems plan. & Marin Countywide Plan \\
\hline Establish a farmer's market. & Marin Countywide Plan \\
\hline $\begin{array}{l}\text { Preserve and protect agricultural lands and } \\
\text { uses as resources. Improve agricultural viability. }\end{array}$ & Marin Countywide Plan \\
\hline $\begin{array}{l}\text { Promote small-scale diversification, and small- } \\
\text { scale crop production. }\end{array}$ & Marin Countywide Plan \\
\hline Encourage agricultural processing. & Marin Countywide Plan \\
\hline $\begin{array}{l}\text { Community Food Security. Why? Locally } \\
\text { available, fresh, organic food provides } \\
\text { numerous health benefits, can be more readily } \\
\text { accessed in the event of an emergency, and } \\
\text { reduces GHG emissions. }\end{array}$ & Marin Countywide Plan \\
\hline $\begin{array}{l}\text { Work with local and regional stakeholders to } \\
\text { develop regional buying incentives by } 2012 \text {. }\end{array}$ & Fresno Green \\
\hline $\begin{array}{l}\text { Work with large manufacturers and food service } \\
\text { operators to remove obstacles and identify } \\
\text { opportunities for piloting decentralized food } \\
\text { purchasing by } 2012 \text {. }\end{array}$ & Fresno Green \\
\hline $\begin{array}{l}\text { Require City food vendors to provide a minimum } \\
\text { of } 20 \% \text { locally grown organic food in orders } \\
\text { received by the City. }\end{array}$ & Burbank Sustainability Action Plan \\
\hline $\begin{array}{l}\text { Use locally grown and/or organic foods in City- } \\
\text { sponsored events. Promote organic food in } \\
\text { schools. }\end{array}$ & Marin Countywide Plan \\
\hline $\begin{array}{l}\text { Encourage all City facilities (including schools) } \\
\text { to serve at least } 20 \% \text { locally grown and organic } \\
\text { foods beginning in } 2009 \text {. }\end{array}$ & Fresno Green \\
\hline $\begin{array}{l}\text { Daily lunches to school children (with some } \\
\text { organic food). }\end{array}$ & Sacramento Implementation Plan \\
\hline $\begin{array}{l}\text { Seek opportunities for community and school } \\
\text { gardens where local residents can grow } \\
\text { vegetables free of pesticides. }\end{array}$ & Burbank Sustainability Action Plan \\
\hline $\begin{array}{l}\text { Encourage the purchase of locally-produced } \\
\text { food. }\end{array}$ & $\begin{array}{l}\text { Sacramento Implementation Plan } \\
\text { Marin Countywide Plan }\end{array}$ \\
\hline $\begin{array}{l}\text { Promote the purchase of fresh, healthy, local, } \\
\text { organic food products and sustainable } \\
\text { agriculture. }\end{array}$ & Marin Countywide Plan \\
\hline $\begin{array}{l}\text { Encourage community gardens \& healthy food } \\
\text { in schools and workplaces. }\end{array}$ & Marin Countywide Plan \\
\hline $\begin{array}{l}\text { Indicator: Percent of fresh, locally-produced, } \\
\text { organic produce served at City facilities and } \\
\text { other institutions (e.g. hospitals, schools, and } \\
\text { City-sponsored food programs) } \\
\text { Target: Annual increase in percent of } \\
\text { organically grown and low-chemical produce } \\
\text { sales over baseline }\end{array}$ & $\begin{array}{l}\text { Santa Monica Sustainable City } \\
\text { Plan }\end{array}$ \\
\hline $\begin{array}{l}\text { Promote the public health and environmental } \\
\text { benefits of supporting locally grown and organic } \\
\text { foods. }\end{array}$ & Fresno Green \\
\hline $\begin{array}{l}\text { Provide outreach to residents on how to eat } \\
\text { better by including organic food in their diets } \\
\text { and to read and understand nutrition labels. }\end{array}$ & Burbank Sustainability Action Plan \\
\hline $\begin{array}{l}\text { Promote certified organic and fair trade } \\
\text { products. Promote edible landscaping. }\end{array}$ & Marin Countywide Plan \\
\hline Landscaping ordinance that supports & Sacramento Implementation Plan \\
\hline
\end{tabular}




\begin{tabular}{|l|l|}
\hline \multicolumn{1}{|c|}{ Action } & \multicolumn{1}{|c|}{ Source } \\
\hline neighborhood gardening. & \\
\hline $\begin{array}{l}\text { Demonstration Landscapes as tools to educate } \\
\text { the public on how to garden and grow their own } \\
\text { food. }\end{array}$ & Sacramento Implementation Plan \\
\hline
\end{tabular}

\section{OBESITY}

Some cities are addressing the rise in the incidence of obesity by promoting physical fitness through community design (e.g. increased open space and recreational opportunities), allowing residents the opportunity to improve their own health.

\begin{tabular}{|l|l|}
\multicolumn{1}{|c|}{ Action } & \multicolumn{1}{|c|}{ Source } \\
\hline $\begin{array}{l}\text { Partner with schools to address the problem of } \\
\text { obesity in children. }\end{array}$ & Marin Countywide Plan \\
\hline $\begin{array}{l}\text { Indicator: Percent of population overweight and } \\
\text { obese by age and gender }\end{array}$ & \\
$\begin{array}{l}\text { Targets: Obesity decreases } 10 \% \text { by } 2015 . \\
\text { Amount of time spent in physical activity by } \\
\text { children } 2-17 \text { increases by } 10 \% \text {. Percentage of } \\
\text { children eating } 5 \text { or more servings of fruit and } \\
\text { vegetables per day increase } 10 \% .\end{array}$ & Marin Countywide Plan \\
\hline $\begin{array}{l}\text { Encourage and promote physical fitness } \\
\text { throughout the City. }\end{array}$ & \\
\hline
\end{tabular}

\section{OUTREACH \& AWARENESS}

To achieve a more sustainable community, cities should conduct outreach to educate and motivate the community to make small changes in their personal behavior. Public involvement is crucial to the implementation of measures helping to achieve sustainability. The actions of City employees, residents, and commercial \& industrial businesses to improve sustainability will ultimately improve public health, safety, and welfare. This section contains broad actions for community outreach, while many other strategies are listed in their respective chapters based on sustainability focus area.

\begin{tabular}{|l|l|}
\hline \multicolumn{1}{|c|}{ Action } & Source \\
\hline $\begin{array}{l}\text { The City will collaborate with local government } \\
\text { associations, including the U.S. Conference of } \\
\text { Mayors, to develop and share climate change } \\
\text { strategies. }\end{array}$ & Los Angeles Climate Action Plan \\
\hline $\begin{array}{l}\text { Adopt an action plan to support a regional vision } \\
\text { that fosters a collaboration of citizens, } \\
\text { businesses and green initiative groups to } \\
\text { become engaged and contribute to a } \\
\text { sustainable future, promote innovative } \\
\text { programs to educate and capture the public's } \\
\text { imagination of global change, commit to leading } \\
\text { by example and foster behavioral change } \\
\text { throughout the City, and promote an ethic of } \\
\text { conservation and stewardship. }\end{array}$ & \\
\hline $\begin{array}{l}\text { Make public buildings didactic through the } \\
\text { development of permanent interpretive panels }\end{array}$ & \\
\hline
\end{tabular}




\begin{tabular}{|c|c|}
\hline Action & Source \\
\hline \multicolumn{2}{|l|}{$\begin{array}{l}\text { at each site that "teach" about the building's use } \\
\text { of green technology. }\end{array}$} \\
\hline $\begin{array}{l}\text { Department of Finance will work with the } \\
\text { Employees Retirement System to explore } \\
\text { options for climate-friendly investing (in } \\
\text { solutions). }\end{array}$ & Seattle Climate Action Plan \\
\hline $\begin{array}{l}\text { Continue to promote the Citywide employee } \\
\text { volunteer program to further engage } \\
\text { volunteerism and spirit of giving. }\end{array}$ & Burbank Sustainability Action Plan \\
\hline $\begin{array}{l}\text { Employee outreach campaign to turn the City's } \\
\text { employees into ambassadors for climate } \\
\text { protection. }\end{array}$ & Seattle Climate Action Plan \\
\hline Introduction to LEED classes for City staff. & Sacramento Implementation Plan \\
\hline $\begin{array}{l}\text { Recruitment effort, targeting the largest } \\
\text { employers, for the Seattle Climate Partnership } \\
\text { (with credibility as a non-governmental } \\
\text { organization), which includes REI, Starbucks } \\
\text { Coffee Company, Port of Seattle, University of } \\
\text { Washington, Shoreline Community College, } \\
\text { King County, and others. }\end{array}$ & Seattle Climate Action Plan \\
\hline $\begin{array}{l}\text { Partner with community organizations to } \\
\text { develop educational materials and reach out } \\
\text { with steps they can take to reduce their own } \\
\text { emissions. }\end{array}$ & Los Angeles Climate Action Plan \\
\hline $\begin{array}{l}\text { Conduct multi-lingual, community-based } \\
\text { outreach to all neighborhoods to inform them of } \\
\text { the development of the actions. }\end{array}$ & Los Angeles Climate Action Plan \\
\hline $\begin{array}{l}\text { Host an annual event with the Mayor and other } \\
\text { civic leaders to recognize and promote the } \\
\text { Partnership's climate protection } \\
\text { accomplishments, thereby increasing } \\
\text { networking and recruitment of new Partners. }\end{array}$ & Seattle Climate Action Plan \\
\hline $\begin{array}{l}\text { Climate protection action-awareness campaign, } \\
\text { employing a variety of media, to make } \\
\text { residents, public institutions, and businesses } \\
\text { aware of the link between their everyday energy } \\
\text { use and the climate crisis. }\end{array}$ & Seattle Climate Action Plan \\
\hline $\begin{array}{l}\text { Develop a myriad of public information material } \\
\text { tailored for diverse audiences and applicable to } \\
\text { website development, media campaigns, and } \\
\text { educational initiatives. }\end{array}$ & Sacramento Implementation Plan \\
\hline $\begin{array}{l}\text { Provide presentations to Neighborhood groups, } \\
\text { business, and community organizations. }\end{array}$ & Sacramento Implementation Plan \\
\hline $\begin{array}{l}\text { Identify target audiences and reach out to target } \\
\text { groups with program information and resources. }\end{array}$ & Sacramento Implementation Plan \\
\hline $\begin{array}{l}\text { Work with local schools to facilitate outreach } \\
\text { and education of school-aged children. }\end{array}$ & Sacramento Implementation Plan \\
\hline $\begin{array}{l}\text { Kids for Climate Protection, new educational } \\
\text { program in schools. }\end{array}$ & Seattle Climate Action Plan \\
\hline $\begin{array}{l}\text { Develop and distribute "Tips to be Sustainable" } \\
\text { at home, work, road, and in the community. }\end{array}$ & Sacramento Implementation Plan \\
\hline $\begin{array}{l}\text { Continue engaging and strengthening residents } \\
\text { through outreach, education, and trust building } \\
\text { efforts in focus neighborhoods in order to } \\
\text { empower and create open communication, } \\
\text { active participation, and meaningful change. } \\
\text { Continue to fortify projects and collaborations } \\
\text { through programs and activities that promote }\end{array}$ & Burbank Sustainability Action Plan \\
\hline
\end{tabular}




\begin{tabular}{|c|c|}
\hline Action & Source \\
\hline $\begin{array}{l}\text { community strength and ownership, civic } \\
\text { engagement, further values of leadership within } \\
\text { neighborhoods and foster community } \\
\text { environments that build long-term social health } \\
\text { and sustainability. }\end{array}$ & \\
\hline $\begin{array}{l}\text { Continue to nurture community partnerships } \\
\text { between focus neighborhood residents, City } \\
\text { employees, non-profits, service clubs, and } \\
\text { businesses to strengthen communication and } \\
\text { quality of life. }\end{array}$ & Burbank Sustainability Action Plan \\
\hline $\begin{array}{l}\text { Develop and implement a technical assistance } \\
\text { program for partners, including: a resource } \\
\text { guide; a web site for sharing ideas, } \\
\text { experiences, best practices and success } \\
\text { stories; training workshops; and direct technical } \\
\text { support from a team of experts in climate } \\
\text { solutions, such as energy conservation and } \\
\text { commute trip reduction. }\end{array}$ & Seattle Climate Action Plan \\
\hline $\begin{array}{l}\text { Indicator: Percent of residents who are aware of } \\
\text { the Ecological Footprint and understand their } \\
\text { contribution to it. Target: } 25 \% \text { by } 2010\end{array}$ & Santa Monica Sustainable City Plan \\
\hline $\begin{array}{l}\text { Indicator: Percent of residents who have an } \\
\text { understanding of how each Sustainable City } \\
\text { goal area is a component of a sustainable } \\
\text { community and the extent to which this affects } \\
\text { their decisions. Target: Upward trend }\end{array}$ & Santa Monica Sustainable City Plan \\
\hline
\end{tabular}

\section{UPdATING Policy \& DeVElopMent REVIEW}

The following Actions were found to best show how cities can amend policy documents and improve development review to promote sustainability.

\begin{tabular}{|l|l|}
\hline \multicolumn{1}{|c|}{ Action } & \\
\hline $\begin{array}{l}\text { Ensure that all goals and policies are consistent } \\
\text { with the intent of this action item. Adopt the } \\
\text { documents such that they become the official } \\
\text { policy of the City and can be effectively }\end{array}$ & Burbank Sustainability Action Plan \\
implemented through the Zoning Ordinance and \\
other regulatory documents.
\end{tabular}




\section{OPTIONS FOR ADOPTION}

Cities have taken several approaches when incorporating sustainability into policies and programs. The City will need to determine which option is most feasible and realistic in terms of adoption and implementation for Patterson, be it a Climate Action Plan, incorporation of sustainability into the existing Conservation Element (Patterson labels it, "Natural Resources Element"), Sustainability Element of the General Plan, sustainability incorporated throughout the General Plan, or a stand-alone Sustainability Plan. For those that have completed a Sustainability Plan in some form, a few have chosen to mirror the 21 Urban Environmental Accords (explained in detail below), while others have chosen their own unique format to organize the plan's contents. There are plans that are less than ten pages in length, while others are more than 100 pages long.

The discussion of each option for adoption assesses the advantages and disadvantages, many of which are disputed as to whether or not they are beneficial or non-beneficial. Following each set of advantages and disadvantages is a list of example jurisdictions that modeled the documents after that option (compiled in December 2008).

\section{OPTION 1: CLIMATE ACTION PLAN (CAP)}

Separate from the General Plan.

The majority of Climate Action Plans focus mainly on reducing greenhouse gas (GHG) emissions to curb climate change. Sustainability, though, is a broader concept that includes the acknowledgement of climate change and actions to revert it, but other measures that promote sustainable economic development, for example, to diversify the economic base and be able to maintain a healthy economy to support the community in the long-term. In the larger scheme of things, Climate Action Plans are very new. As such, there is no set standard to date. Some Climate Action Plans, in addition to measures that reduce GHG emissions, include measures that address sustainability, but do not necessarily help reduce GHG emissions. Below are some advantages and disadvantages to the option of a Climate Action Plan:

Advantages:

- Will allow more specific policies and implementation measures addressing climate change and sustainability (as opposed to more general policies in the General Plan).

- Helpful to have everything related to sustainability and climate change in one place.

- City held more accountable for implementation.

- Easier to adopt (by resolution). More receptive to residents and business community.

- Could still be referenced in the General Plan by a few policies (e.g., "Prepare a Climate Action Plan).

Disadvantages:

- Focuses solely on reducing GHG emissions. 
- Climate change and sustainability are relevant to all topics throughout the General Plan. As such, they should be integrated throughout the document.

- May require CEQA review

Example Climate Action Plans:

- Sacramento is pursuing a Climate Action Plan

- Davis is working on Emissions Inventory and pursuing a CAP

- Phoenix Climate Action Plan coming July 2009

- Irvine is working on Emissions Inventory and CAP

- Salt Lake City Climate Action Plan (website)

- Chicago Climate Action Plan (CCAP)

- Tacoma Climate Action Plan July 2008 (33 pg)

- $\quad$ Berkeley Climate Action Plan $2^{\text {nd }}$ DRAFT September 2008 (179 pg)

- Pittsburgh Climate Action Plan Version 1.0 June 2008 (125 pg)

- Nevada Climate Change Advisory Committee Final Report May 2008 (70 pg)

- Evanston, IL Climate Action Plan (ECAP) DRAFT May 2008 (18 pg)

- Palo Alto Climate Protection Plan December 2007 (114 pg)

- City of Los Angeles Harbor Department/Port of Los Angeles Climate Action Plan - Strategies for Municipally-Controlled Sources December 2007

- Boston's Climate Action Plan December 2007 (32 pg)

- Montana Climate Change Action Plan November 2007 (93 pg)

- Colorado Climate Action Plan November 2007 (35 pg)

- Denver Climate Action Plan October 2007 (46 pg)

- City of Aspen Canary Initiative Climate Action Plan 2007-2009 May 2007 (38 pg)

- Philadelphia Local Action Plan for Climate Change April 2007 (33 pg)

- Adapting to Climate Change in Stockholm March 2007 (36 pg)

- King County, Washington Climate Plan 2007 (178 pg)

- New Mexico Climate Change Advisory Group Final Report December 2006 (ll pg)

- Worcester, Massachusetts Climate Action Plan December 2006 (236 pg)

- Arizona Climate Change Action Plan August 2006 (100 pg)

- City of Boulder Climate Action Plan September 2006 (72 pg)

- Seattle Climate Action Plan (SeaCAP) September 2006 (40 pg)

- Town of Carbondale Energy \& Climate Protection Plan: Creating a Strong Carbondale Economy with Clean Energy (17 pg)

- Contra Costa County Climate Protection Report November 2005 (4l pg)

- Vancouver: The Climate-Friendly City - A Community Climate Change Action Plan March 2005 (55 pg)

- Maine Climate Action Plan December 2004 (1ll pg)

- Climate Action Plan For San Francisco September 2004 (140 pg)

- Town of Brattleboro, Vermont Climate Action Plan October 2003 (42 pg)

- Stockholm's Action Programme Against Greenhouse Gas Emissions 2003 $(34 \mathrm{pg})$

- Portland Local Action Plan on Global Warming April 2001 (39 pg)

- Chula Vista $\mathrm{CO}_{2}$ Reduction Plan November 2000 (75 pg)

- Delaware Climate Change Action Plan January 2000 (210 pg) 


\section{OPTION 2: PART OF GENERAL PLAN ELEMENT}

One option is to integrate sustainability into the existing General Plan Conservation Element (labeled "Natural Resources Element” in Patterson).

According to the San Diego Area Council of Governments (SANDAG) Background Report on Climate Action Plans, the City of San Diego, after adopting its Climate Protection Action Plan in July 2005, "incorporated climate change mitigation strategies into the Conservation Element of its August 2007 Draft General Plan Update" (p.12). The draft Conservation Element "introduces eleven policies under the rubric of Climate Change and Sustainable Development. Many of these policies seek to promote green building and energy efficiency in the community. In addition, the element provides a matrix indicating how climate change has implicitly addressed other elements of the Draft General Plan, including Land Use/Community Planning, Mobility, Urban Design, Recreation, and Public Facilities, Services, and Safety" (p.13). Implementation strategies are provided in the Conservation Element, not in the Climate Protection Action Plan. Below are some advantages and disadvantages to the option of integrating sustainability into an existing Element:

Advantages:

- Helpful to have everything related to sustainability in one place. Disadvantages:

- Would require findings of internal consistency.

- Would require amendments of the Zoning Ordinance and Subdivision Ordinance to ensure consistency with the General Plan.

- Sustainability is relevant to all topics. As such, it should be integrated throughout.

- Subject to CEQA review

Example jurisdictions:

- City of San Diego Conservation Element (March 2008)

- City of Chula Vista Environmental Element December 2005 (and in Public Facilities \& Services Element)

OPTION 3: INTEGRATED THROUGHOUT THE GENERAL PLAN

Integrated into each General Plan Element.

Advantages:

- Sustainability is relevant to all topics. As such, it should be integrated throughout.

Disadvantages:

- Would require findings of internal consistency.

- Would require amendments of the Zoning Ordinance and Subdivision Ordinance to ensure consistency with the General Plan.

- CEQA compliance

City of PATTERSON JUNE 2009 SUSTAINABILITY PLAN 
Example jurisdictions:

- Sustainable Northampton, Massachusetts Comprehensive Plan January 2008

- Marin Countywide Plan November 2007

- Seattle Comprehensive Plan (Toward a Sustainable Seattle) January 2005

\section{OPTION 4: SUSTAINABILITY ELEMENT}

Included in General Plan as a separate optional Element.

Boulder County, in its (May 2007) Sustainability Element of the Comprehensive Plan, acknowledges that, "in its fullest expression, sustainability should influence and connect all of the other Elements in the Plan." The American Planning Association (APA) Policy Guide On Planning \& Climate Change (April 2008) recommends that, "climate planning elements should be incorporated in comprehensive plans" (p.12).

\section{Advantages:}

- Helpful to have everything related to sustainability in one place.

Disadvantages:

- Would require findings of internal consistency.

- Would require amendments of the Zoning Ordinance and Subdivision Ordinance to ensure consistency with the General Plan.

- More difficult to adopt. City \& citizens may be less receptive.

- CEQA compliance

Example jurisdictions:

- City of Chico is developing a Sustainability Element

- City of Madera is developing a Sustainability Element

- City of Rohnert Park is developing a Sustainability Element

- City of Berkeley Environmental Management Element April 2002

- City and County of San Francisco Environmental Protection Element

- City of Benicia Community Development and Sustainability Element (1999)

\section{OPTION 5: SUSTAINABILITY PLAN}

Separate from General Plan. It differs from a Climate Action Plan in that it focuses on long-term objectives toward achieving sustainability, many of which may not be directly related to reducing greenhouse gas emissions.

A stand-alone document may be ideal, at least as a starting point, so that the City can organize the desired actions before incorporating policies and programs into the General Plan. The City can then add the appropriate (general) topics to the General Plan, while leaving out more specific actions that may not belong in the General Plan.

\section{Advantages:}

- Will allow more specific policies and implementation measures addressing climate change and sustainability (as opposed to more general policies in the General Plan). 
- Helpful to have everything related to sustainability in one place.

- City held more accountable for implementation.

- Easier to adopt (by resolution). More receptive to residents and the business community.

- May not immediately require amendments of the Zoning Ordinance and Subdivision Ordinance to ensure consistency with the General Plan.

- Could still be referenced in General Plan by a few policies (e.g., "Prepare a Sustainability Plan" or "Ensure that each approved application is consistent with the Sustainability Plan," or "Promote energy efficiency" and "Encourage water conservation").

Disadvantages:

- Sustainability is relevant to all topics. As such, it should be integrated throughout.

Example Sustainability Plans:

- Culver City is working on a Sustainable Community Plan (SCP)

- Princeton NJ working on a Sustainable Princeton Community Plan

- Baltimore DRAFT Sustainability Plan December 2008

- Sustainable Santa Fe Plan October 2008 (52 pg)

- Building A Bright Future: San Francisco's Environmental Plan 2008 (28 pg)

- Fresno Green: The City of Fresno's Strategy for Achieving Sustainability May 2008 (19 pg)

- UC Santa Barbara Campus Sustainability Plan April 2008

- Ahupua'a, Honolulu: Working Toward the $21^{\mathrm{st}}$ Century Ahupua'a. April 2008. Version 1.l (96 pg)

- Creating A Sustainable City: Implementation Plan, City of Sacramento Feb $2008(25 \mathrm{pg})$

- Princeton University Sustainability Plan February 2008 (10 pg)

- Hawai'i 2050 Sustainability Plan January 2008 (99 pg)

- Burbank Sustainability Action Plan January 2008 (76 pg)

- Summary Table (15 pg)

- Phoenix: Living Like it Matters! Environmental Sustainability Program 2008 (43 pg)

- Portland Development Commission (PDC) Sustainability Plan Sep. 2007 to Sep. 2008 (17 pg)

- Creating A Sustainable City: A Master Plan to Move the City of Sacramento Towards Sustainability December 2007 (17 pg)

- London 2012 Sustainability Plan: Towards a one planet 2012 November 2007 (68 pg)

- San Jose's Green Vision Plan October 2007 (14 pages)

- Pasadena Green City Action Plan 2006 (ll pg)

- Santa Monica Sustainable City Plan October 2006 (30 pg)

- Green Riverside: Clean and Green Sustainable Riverside Action Plan (6 pg)

- New York City's PLANYC: A Greener, Greater New York (158 pg)

- Oregon Dept. of Transportation Sustainability Plan March 2004 (38 pg)

- U.S. Army Strategy for the Environment: Sustain the Mission - Secure the Future October 2004 (12 pg)

- A New Path Forward: Action Plan for a Sustainable Washington February $2003(36$ pg) 
- $\quad$ Recipe For A Liveable Sydney July 2002 (15 pg)

- Sustainability Plan for San Francisco October 1996

Example Sustainability Reports:

- Cal Poly Facilities \& Operations Sustainability Plan: Second Biennial Progress Report 2008

- Sustainable Santa Barbara Annual Report 2008 (31 pages)

- Santa Monica Sustainable City Report Card September 2008 (6 pg)

- Santa Monica Sustainable City Progress Report (Ongoing, website)

- Port of Los Angeles Sustainability Assessment and Plan Formulation June 2008 (40 pg)

- Pasadena Green City Report 2007

- County of Marin Sustainability Status Report December 2007

- UC Santa Cruz Campus Sustainability Assessment 2007 (96 pg)

- Seattle Climate Action Plan (SeaCAP) Progress Report 2007

- County of Marin Operations Report: Measuring Progress Towards Sustainability April 2006

- UC Berkeley Campus Sustainability Assessment 2005 (122 pg)

- Port of Oakland Environmental Annual Report 2005 (2l pages)

- Port of Oakland Sustainability Program Annual Report 2003 (17 pages)

\section{URBAN ENVIRONMENTAL ACCORDS}

For those jurisdictions that choose the Sustainability Plan option, many model the document after the Urban Environmental Accords, made up of 21 Actions. On June 5, 2005, the United Nations and more than 60 mayors from all over the globe met on World Environment Day in San Francisco to sign the Urban Environmental Accords - Green Cities Declaration, encouraging other cities to implement as many of the Actions as possible before 2012. The U.S. Mayors Climate Protection Agreement is an influential, and growing, coalition of more than 935 municipal leaders taking local action in their cities to combat global warming and calling for stronger federal leadership.

Many cities, including the City of Sacramento with its Sustainability Master Plan, the City of Pasadena with its Green City Action Plan and the City of Burbank with its Sustainability Action Plan (January 2008), have chosen to use the following Actions as a model, adapting them to their own needs, and adding as necessary to satisfy specific local needs. Under each Action item in the Burbank Sustainability Action Plan, are a number of specific policies and programs to achieve successful implementation. Next to each Action Item is the "Status," indicated as "Existing - On-going," "New - Administrative," which means a new Staff-driven initiative is needed, or "New - Legislative," which means City Council needs to adopt a new ordinance, resolution, or plan.

The focus areas of the Urban Environmental Accords are Energy (renewable energy, energy efficiency, climate change), Waste Reduction (zero waste, manufacturer responsibility, consumer responsibility), Urban Design (green building, urban planning, slums), Urban Nature (parks, habitat restoration, wildlife), Transportation (public transportation, clean vehicles, reducing

CITY of PATTERSON JUNE 2009 SUSTAINABILITY PLAN 
congestion), Environmental Health (toxics reduction, healthy food systems, clean air), and Water (water access and efficiency, source water protection, waste water reduction).

The Green Cities Declaration and 21 Actions are listed below:

\section{$\underline{\text { Declaration }}$}

Recognizing that for the first time in history, the majority of the planet's population now lives in cities and that continued urbanization will result in one million people moving to cities each week, thus creating a new set of environmental challenges and opportunities; and

Believing that as Mayors of cities around the globe, we have a unique opportunity to provide leadership to develop truly sustainable urban centers based on culturally and economically appropriate local actions; and

Recalling that in 1945 the leaders of 50 nations gathered in San Francisco to develop and sign the Charter of the United Nations; and

Acknowledging the importance of the obligations and spirit of the 1972 Stockholm Conference on the Human Environment, the 1992 Rio Earth Summit (UNCED), the 1996 Istanbul Conference on Human Settlements, the 2000 Millennium Summit, and the 2002 Johannesburg World Summit on Sustainable Development, we see the Urban Environmental Accords described below as a synergistic extension of the efforts to advance sustainability, foster vibrant economies, promote social equity, and protect the planet's natural systems;

Therefore, be it resolved, today on World Environment Day 2005 in San Francisco, we the signatory Mayors have come together to write a new chapter in the history of global cooperation. We commit to promote this collaborative platform and to build an ecologically sustainable, economically dynamic, and socially equitable future for our urban citizens; and

Be it further resolved that we call to action our fellow Mayors around the world to sign the Urban Environmental Accords and collaborate with us to implement the Accords; and

Be it further resolved that by signing these Urban Environmental Accords, we commit ourselves to moving vital issues of sustainability to the top of our legislative agendas. By implementing the Urban Environmental Accords, we aim to realize the right to a clean, healthy, and safe environment for all members of our society.

$\underline{\text { Actions }}$

Energy

Action 1 Adopt and implement a policy to increase the use of renewable energy to meet ten percent of the city's peak electric load within seven years (by 2012).

Action 2 Adopt and implement a policy to reduce the city's peak electric load by ten per cent within seven years through energy efficiency, shifting

City of PATTERSON JUNE 2009 SUSTAINABILITY PLAN 
the timing of energy demands, and conservation measures.

Action 3 Adopt a citywide greenhouse gas reduction plan that reduces the jurisdiction's emissions by twenty-five per cent by 2030, and which includes a system for accounting and auditing greenhouse gas emissions.

\section{Waste Reduction}

Action 4 Establish a policy to achieve zero waste going to landfills and incinerators by 2040 .

Action 5 Adopt a citywide program that reduces the use of a disposable, toxic, or non-renewable product category by at least fifty per cent in seven years.

Action 6 Implement "user-friendly" recycling and composting programs, with the goal of reducing by twenty per cent per capita solid waste disposal to landfill and incineration in seven years.

\section{Urban Design}

Action 7 Adopt a policy that mandates a green building rating system standard that applies to all new municipal buildings.

Action 8 Adopt urban planning principles and practices that advance higher density, mixed use, walkable, bikeable, and disabled-accessible neighborhoods which coordinate land use and transportation with open space systems for recreation and ecological restoration.

Action 9 Adopt a policy or implement a program that creates environmentally beneficial jobs in slums and/or low-income neighborhoods.

\section{Urban Nature}

Action 10 Ensure that there is an accessible public park or recreational open space within half-a-kilometer of every city resident by 2015 .

Action 11 Conduct an inventory of existing canopy coverage in the city and then establish a goal based on ecological and community considerations to plant or maintain canopy coverage in not less than 50 per cent of all available sidewalk planting sites.

Action 12 Pass legislation that protects critical habitat corridors and other key habitat characteristics (e.g. water features, food-bearing plants, shelter for wildlife, use of native species, etc.) from unsustainable development.

\section{Transportation}

Action 13 Develop and implement a policy which expands affordable public transportation coverage to within half-a-kilometer of all city residents in ten years.

Action 14 Pass a law or implement a program that eliminates leaded gasoline (where it is still used); phases down sulfur levels in diesel and gasoline fuels, concurrent with using advanced emission controls on all buses, taxis, and public fleets to reduce particulate matter and smogforming emissions from those fleets by 50 per cent in seven years. 
Action 15 Implement a policy to reduce the percentage of commuter trips by single occupancy vehicles by ten per cent in seven years.

\section{Environmental Health}

Action 16 Every year, identify one product, chemical, or compound that is used within the city that represents the greatest risk to human health and adopt a law and provide incentives to reduce or eliminate its use by the municipal government.

Action 17 Promote the public health and environmental benefits of supporting locally grown organic foods. Ensure that twenty per cent of all city facilities (including schools) serve locally grown and organic food within seven years.

Action 18 Establish an Air Quality Index (AQI) to measure the level of air pollution and set the goal of reducing by 10 per cent in seven years the number of days categorized in the AQI range as "unhealthy" or "hazardous."

\section{Water}

Action 19 Develop policies to increase adequate access to safe drinking water, aiming at access for all by 2015 . For cities with potable water consumption greater than 100 liters per capita per day, adopt and implement policies to reduce consumption by 10 per cent by 2015 .

Action 20 Protect the ecological integrity of the city's primary drinking water sources (i.e., aquifers, rivers, lakes, wetlands and associated ecosystems).

Action 21 Adopt municipal wastewater management guidelines and reduce the volume of untreated wastewater discharges by ten per cent in seven years through the expanded use of recycled water and the implementation of a sustainable urban watershed planning process that includes participants of all affected communities and is based on sound economic, social, and environmental principles.

\section{CONCLUSION}

Patterson can learn a great deal from other cities. After a thorough review of best practices in several jurisdictions known for their efforts toward achieving greater sustainability, the City now has the opportunity to adapt these model policies, actions, and indicators to work in Patterson, in addition to developing new ones to address specific issues unique to Patterson.

\section{WHICH OPTION FOR ADOPTION?}

Some jurisdictions use more than one option. For example, Seattle has both a Climate Action Plan and a Comprehensive Plan that incorporates sustainability throughout. In March 2009, the City of Sacramento adopted its 2030 General Plan with principles of sustainability incorporated throughout, although the City first adopted its Sustainability Master Plan as a stand-alone document. In the end, any of the options (Climate Action Plan, incorporation of sustainability into the existing Natural Resources Element, Sustainability Element, sustainability incorporated throughout the General 
Plan, or a stand-alone Sustainability Plan) enhance the ability to achieve internal operations and residential and business practices that promote sustainability, and each provides the City with an opportunity for enhanced civic pride.

The Patterson General Plan, adopted on September 7, 2004, is made up of two documents: the Background Report and the Policy Document. The 2004 revision of the General Plan was not a comprehensive update, but intended to bring the Plan into conformance with amendments to State Law, and to re-affirm the Plan's goals, objectives, and policies. The City is currently updating the General Plan, making this an ideal opportunity to incorporate principles of sustainability.

The process of compiling this Best Practices Review helped inform the determination of which of the plan format options is most feasible and realistic in terms of adoption and implementation for the City of Patterson. The City will develop a stand-alone Sustainability Plan - The City of Patterson Sustainability Plan (PSP) - which will inform the General Plan update, incorporating principles of sustainability. Because the City seeks greater flexibility in the development of its plan, it will not model the PSP after the 21 Actions of the Urban Environmental Accords, but the Plan will adapt and incorporate many of the measures that are applicable to Patterson. The best approach for Patterson is a stand-alone plan because it allows both broad policies to inform decision-making (as in a General Plan), as well as incorporating specific implementation measures (Actions) to achieve sustainability. The City also considers it very useful to have all of its Goals and Actions related to sustainability in one place, and hopes the community will find it easier to hold the City accountable. The City also finds a standalone plan beneficial because it will revise the plan regularly as priorities change, following the Annual Progress Report, and incorporate broader policies throughout the General Plan, referencing the Sustainability Plan. Within the Near-Term, the City will also develop, adopt, and implement a Climate Action Plan as a separate document, focusing solely on innovative strategies to reduce greenhouse gas (GHG) emissions. 


\section{APPENDIX B NEEdS AssessMeNT \& POLICY AUdIT}

\section{INTRODUCTION}

Sustainability, according to the 1987 Brundtland Report, is defined as "meeting the needs of the present generation without compromising the ability of future generations to meet their needs." The Commission formulated this all-encompassing definition which still applies today. Sustainability is also widely known to have three components: economy, environment, and social equity. The term "sustainability" has not yet been explicitly mentioned in any of Patterson's policy documents, but the City is already addressing some measures of sustainability with current policies and practices. This document contains an inventory and analysis of existing General Plan goals, objectives, policies, and programs supporting sustainability (organized by General Plan Element), to evaluate current conditions in Patterson (strengths and challenges), and determine what areas of policy need change in order to further promote the concept of sustainability. The policies of Stanislaus County will also be analyzed, to gain an understanding of the context in which Patterson lies, especially the agricultural land surrounding the City.

The following documents, among others, were reviewed:

- Patterson General Plan (2004)

- Patterson Bicycle Master Plan (2001)

- Patterson Commuter Survey (March 2004)

- Patterson Community Design Guidelines (October 2002)

- Patterson Non-Potable Water Master Plan and Feasibility Study (July 2008)

- $\quad$ Patterson Urban Water Management Plan (December 2006)

- Villages of Patterson Development Plan EIR (2006)

- Stanislaus County General Plan (1994)

- Stanislaus County Non-Motorized Transportation Plan (September 2008)

- Stanislaus County Visioning Project 2000 (January 2002)

- California Farmland Conversion Report (December 2006)

For the purpose of this study, a goal is defined as a general direction, or an ideal future end related to public health, safety, and welfare. A policy is defined as a statement that guides decision-making and actions taken. Many of Patterson's General Plan policies already address practices of water conservation, energy efficiency, and compact growth, for example, but the purpose of achieving sustainability is not mentioned, and the language utilized in each of these policies does not require action; it only encourages it. An objective is defined as a specified end, condition, or state (measurable and time-specific whenever possible) that is an intermediate step toward attaining a goal. A program is an implementation measure, action, or technique to carry out a policy. The intent of the proposed Sustainability Plan is to require a proactive approach to implementing actions to achieve sustainability. 


\section{CITY PROFILE}

Patterson is a community of about 21,000 people (an $83 \%$ increase, or nearly double the 11,600 residents counted in the 2000 Census) located approximately 20 miles southwest of Modesto (the County seat), in the western part of Stanislaus County, in the San Joaquin Valley. The nearest community is Westley, six miles northwest of Patterson. The selfproclaimed "Apricot Capital of the World" is adjacent to Interstate-5 and three miles west of the San Joaquin River. Highway-33 runs northwestsoutheast along $2^{\text {nd }}$ Street, separating the downtown core from industrial uses to the east. Incorporated in 1919, Patterson is a small, rural town of about three square miles, surrounded by agricultural land, and a history of apricots, almonds, walnuts, dry beans, tomatoes, broccoli, spinach, peas, and melons. The City derives much of its economic vitality from agriculture and food processing, but it also has a large and expanding business park. Patterson's street layout, inspired by the metropolitan areas of Paris, France and Washington, D.C., features a circular format in the central district surrounded by radiating streets. The City is also known for its tree-lined main thoroughfares (eucalyptus, sycamore, and palm trees). In recognition of its agricultural heritage, the City is home to the annual Apricot Fiesta in June.

Figure B-1. State and Regional Location

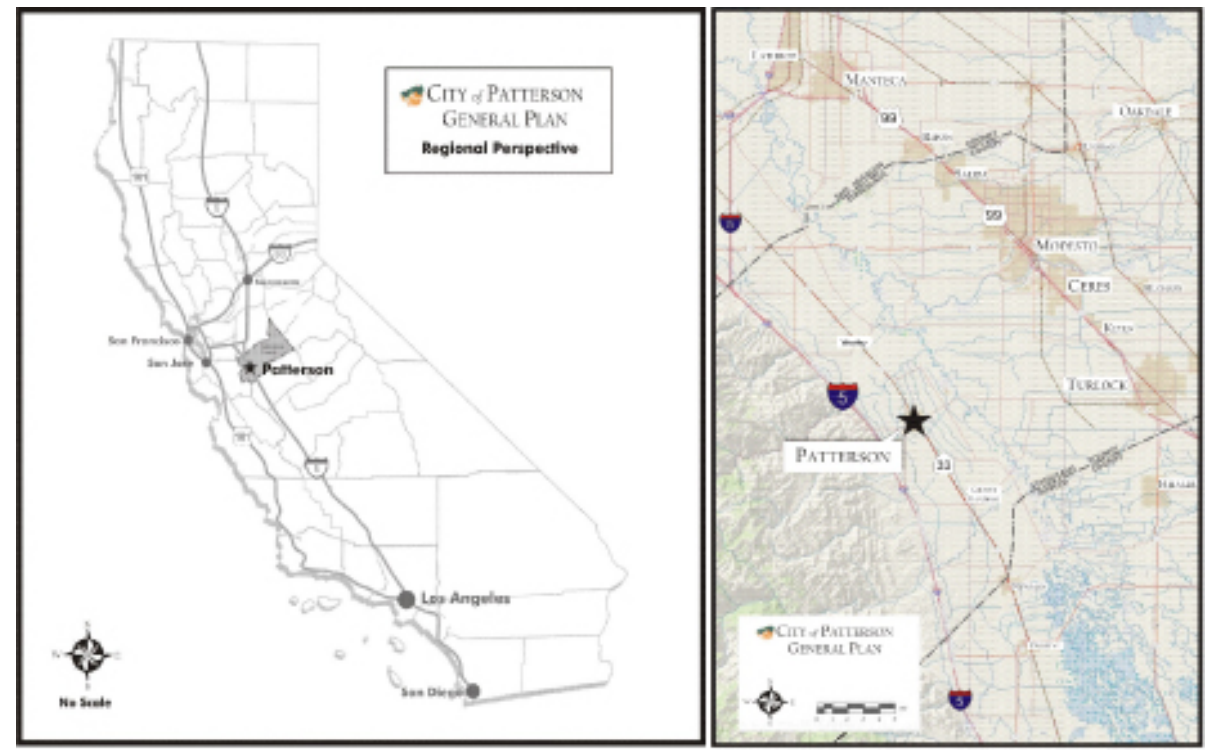

Source: General Plan (2004)

\section{EXISTING CONDITIONS}

\section{COMMUNITY STRENGTHS PROMOTING SUSTAINABILITY}

The following is a discussion of community strengths, organized by each of the focus areas of sustainability that will be present in the Sustainability Plan. 


\section{LAND USE \& COMMUNITY DESIGN}

Downtown Patterson was originally designed on a hub-and-spoke street pattern, resulting in a fairly compact development pattern. Traffic circles (roundabouts), although not mandated by ordinance, are required in new subdivisions, often included in the development agreement. For example, the Villages of Patterson project (in the northeast corner of the City), approved in 2006 (but not yet built), is designed around a traffic circle mimicking the original, El Circulo. At build-out, this area could have as many as 3,100 additional dwelling units, or about 9,000 residents. In Downtown and at major intersections, the City is building curb extensions and bulb-outs that narrow the overall width required by pedestrians to cross the street.

Patterson, as a whole, has the advantage of being a relatively small city, making alternative transportation more viable. There is also an abundance of parks. New development is assessed an impact fee to help fund public parks. With a limited amount of effort, the opportunity to be a sustainable community is well within the grasp of Patterson city officials, business owners, and residents - especially given the General Plan policies and Community Design Guidelines promoting "smart growth." The County has a policy (County Policy GP 24) of referring all development within the Sphere of Influence to the City for approval prior to taking action. This allows the City to have great influence in achieving a compact urban form, preventing traditional sprawling land development patterns. The City also conducts a build-out analysis each year, and regularly reviews its supply of vacant land. In November 2008, the City had 1,865 acres of vacant land, 693 acres of which are designated Light Industrial, 516 acres Low Density Residential, 321 acres Medium Density Residential, and 59 acres Downtown Core. There are 361 acres of underutilized land designated as Estate Residential, and 77 acres of General Commercial. With so many acres of vacant and underutilized residential land, the City has great potential to influence future development to be more compact and more sustainable.

Figure B-2. Vacant Land (December 2008)

\begin{tabular}{|l|l|}
\hline General Plan Designation & Acres \\
\hline Downtown Core & 58.64 \\
\hline Heavy Industrial & 91.4 \\
\hline High Density Residential & 14.03 \\
\hline Highway Service Commercial & 60.8 \\
\hline Light Industrial & 692.54 \\
\hline Low Density Residential & 515.5 \\
\hline Medical Professional & 3.78 \\
\hline Medium Density Residential & 321.26 \\
\hline Parks/Open Space & 71.49 \\
\hline Public/Quasi-Public & 35.43 \\
\hline TOTAL & $\mathbf{1 8 6 4 . 8 7}$ \\
\hline
\end{tabular}

Source: Crawford Multari \& Clark Associates

The City has designated a Historic Preservation Overlay District, a tool that is part of a defined program that retains and preserves historic structures. As a result, there is potential to promote adaptive reuse, and minimize the necessity for new building construction. 
The Modesto Bee newspaper, with the help of planning experts from October 2007 to January 2008, polled 68 planning directors from the eightcounty San Joaquin Valley, evaluating planning policies (not what physically exists) for widely-accepted smart growth principles including public outreach, development, fees, transportation \& infrastructure, design, amenities, affordability, agriculture \& open space, and economic development. Patterson ranked $2^{\text {nd }}$ overall, out of 60 communities, with a score of 77.25 percent, behind Oakdale (79.5\%). According to the study, no city scored higher in design (100\%), developer fees (88\%), and affordability $(87 \%)$. The study found the City's comprehensive landscaping, street furniture, building, thematic and color design standards to be "second to none," but the City could "feel pain in the future, however, without water and sewer improvements." According to an October 2008 Modesto Bee article, Patterson "recognized its mistakes it made with some developments" and amended its General Plan in 2004 to include policies similar to those neo-traditional development principles embraced by Oakdale and Turlock almost 15 years ago.

Within the City, there is a considerable amount of undeveloped commercial $\&$ industrial land, therefore a great potential for improving principles of sustainability (e.g. compact \& more dense urban form, pedestrian-oriented development, green building), especially within the West Patterson Business Park, the commercial areas located at the intersection of Ward Avenue and Sperry Avenue, and on the south side of Sperry Avenue at the Interstate-5 interchange.

CITY of PATTERSON JUNE 2009 SUSTAINABILITY PLAN 
Figure B-3. Existing Land Use Map

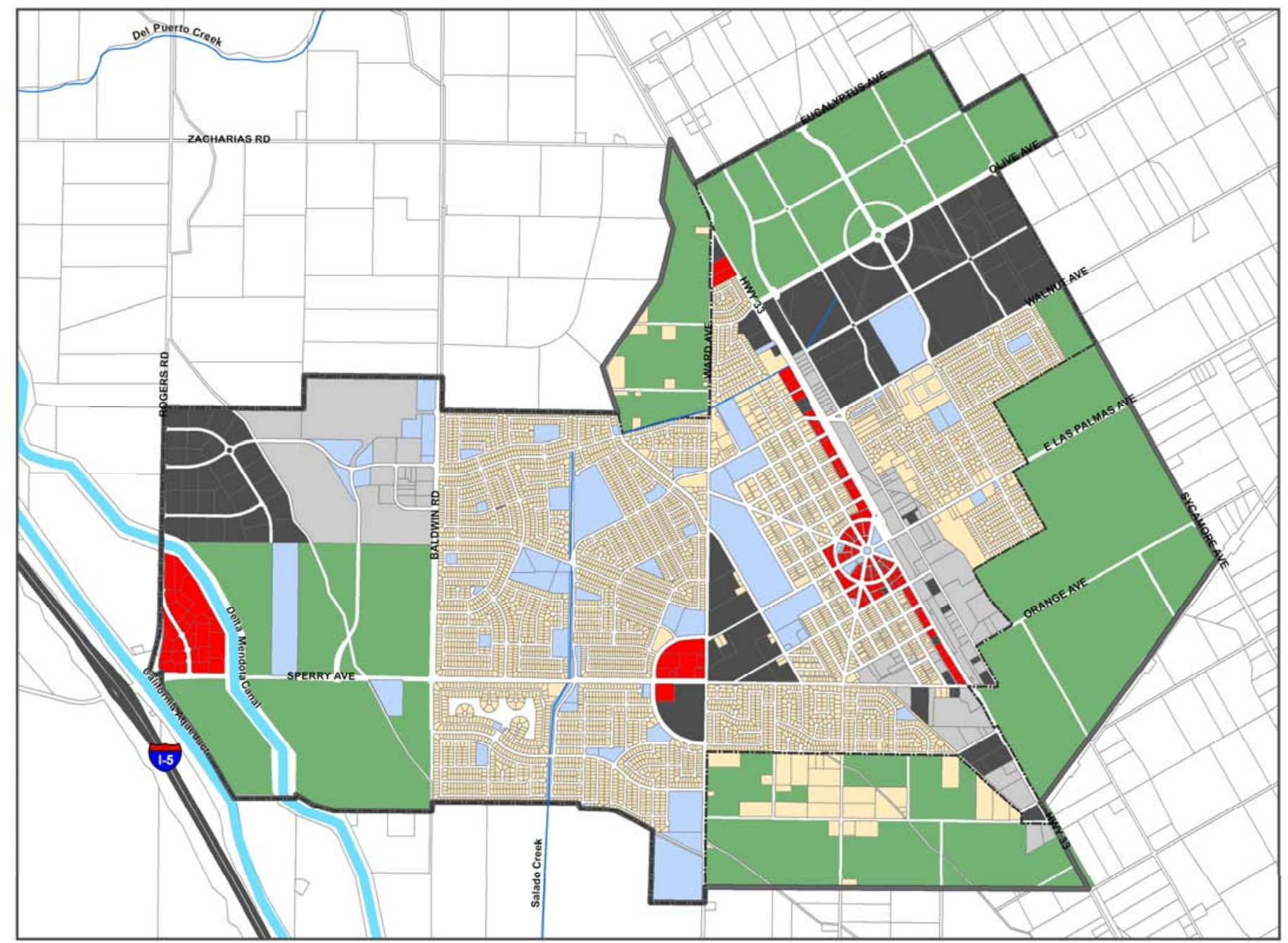

City of Patterson
General Plan

BACKGROUND REPORT

Legend

Existing Land Uses

Agriculture

Commercia

Industrial

Public/Quasi-Public

Residentia

vacant

[.].] City Limits

Sphere of Influence

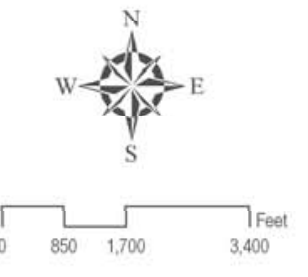

Source: General Plan Background Report (2007)

City of PATTERSON JUNE 2009 SUSTAINABILITY PLAN 


\section{TRANSPORTATION}

According to the Stanislaus County Non-Motorized Transportation Plan (StanCOG, September 2008), Patterson has four miles of bikeways, three of which are classified as Class II facilities (bikes lanes painted on the road). Some of these bike lanes can easily be seen by walking through one of the City's newer subdivisions.

Stanislaus Regional Transit Service (StaRT) offers fixed-route service from Patterson east toward Turlock (Route 45, 6:16am to 7:37pm weekdays and 6:3lam to 6:39pm on Saturdays), and from Patterson north to Modesto, with stops in Westley and Grayson (Route 40, 6:26am to 7:37pm weekdays and 6:40am to 6:35pm on Saturdays).

In 2008, there was a "Commute Green in the San Joaquin" friendly competition amongst employees from the Air District and 23 small, medium, and large organizations, promoting alternative commutes such as carpooling, vanpools, bicycles, electric vehicles, and telecommuting (Healthy Air Living website). The City of Patterson should encourage local businesses, and its own employees, to participate in the future.

\section{WASTE REDUCTION \& RECYCLING}

The City has a curbside garbage, green waste (e.g. lawn clippings, trimmed tree branches, leaves, weeds), and recycling program, collected by Bertolotti Disposal. Polystyrene (Styrofoam) is recyclable in Patterson. Garbage and recyclables are taken to a materials recovery facility (MRF) for sorting and separation of paper, plastics, glass, aluminum, and other materials. Sorted bales and bins of materials are then taken to processing facilities to be sold as resources for making new products. Used oil and oil filters can be disposed of at local auto care facilities inside City limits.

The Bertolotti Transfer and Recycling Center, owned and operated by a private company, is a large-volume transfer station permitted to receive general waste and recyclables from residential, commercial and industrial sources (p. 1-97). The County Plan puts forth a future perspective, acknowledging that, "projects like composting operations and material recovery facilities need to be planned for and encouraged. Facilities and projects that deal with the diversion of special wastes (food processing residue, demolition/construction waste, inert wastes, tires, de-watered sewage sludge and household hazardous wastes) should be allowed to continue and expand as justifiable" (p. 1-98).

In September 1989, the Integrated Waste Management Act mandated a 50 percent solid waste reduction by 2000. Stanislaus County and its eight cities have a diversion rate of 52 percent, partially attributable to the Fink Road Waste-To-Energy Facility that gives these jurisdictions a 10 percent diversion credit for transforming garbage into electricity. Ten percent of the local solid waste agency's 52 percent is the result of that credit.

At the Fink Road Landfill, the Stanislaus County Environmental Resources Department diverts materials from the waste stream for recycling or re-use,

City of PATTERSON JUNE 2009 SUSTAINABILITY PLAN 
including appliances (white goods), electronics (E-waste), and tires (stancounty.com). The Department also provides an illegal roadside dumping clean-up program in collaboration with the Sheriff's Office, Abandoned Vehicle Abatement, and Code Enforcement (stancounty.com). The Fink Road Landfill, owned and operated by the Stanislaus County Environmental Resources Department, has a Class III fill operation for general refuse and a Class II monofill used exclusively for ash residual from the waste-to-energy facility, which is known as the Stanislaus Resource Recovery Facility, or SRRF (p. 1-97). The garbage burner handles about 243,300 tons of garbage each year, reducing the volume of solid waste by $90 \%$ and greatly increasing the life of available landfill space (SRRF website). SRRF recycles ferrous metals at an average of 450 tons each month and 5,400 tons annually (SRRF website).

\section{ENERGY}

Owned and operated by a private company (Covanta Energy), the Stanislaus Resource Recovery Facility (SRRF) is an 800-ton-per-day, mass-burn, waste-to-energy facility, where electricity is generated and sold to Pacific Gas \& Electric to offset the cost of the plant construction, operation, and maintenance (p. 1-97). The facility processes 800 tons per day of solid waste, which generates up to 22.5 megawatts of renewable energy (Covanta Energy website). Approximately 3.5 megawatts are consumed in-house for SRRF operations and the remaining 19 megawatts (average of 135,500 megawatts annually) is sold to PG\&E (SRRF website), enough to power 18,000 homes. The SRRF is located on 16.5 acres adjacent to the Fink Road Landfill and, according to its website, "cars driving by on Interstate-5 neither see nor smell the garbage being processed." Since opening in 1989, this facility has processed over 4.9 million tons of garbage and has generated more than 2.4 billion kilowatt-hours of electricity (SRRF website). SRRF's power generation is considered by the U.S. EPA to be a "clean, reliable, renewable source of energy" and is recognized by the State of California as eligible for the Renewable Portfolio Standard (RPS) required of investor-owned utilities (SRRF website). Incineration is exempt from CEQA.

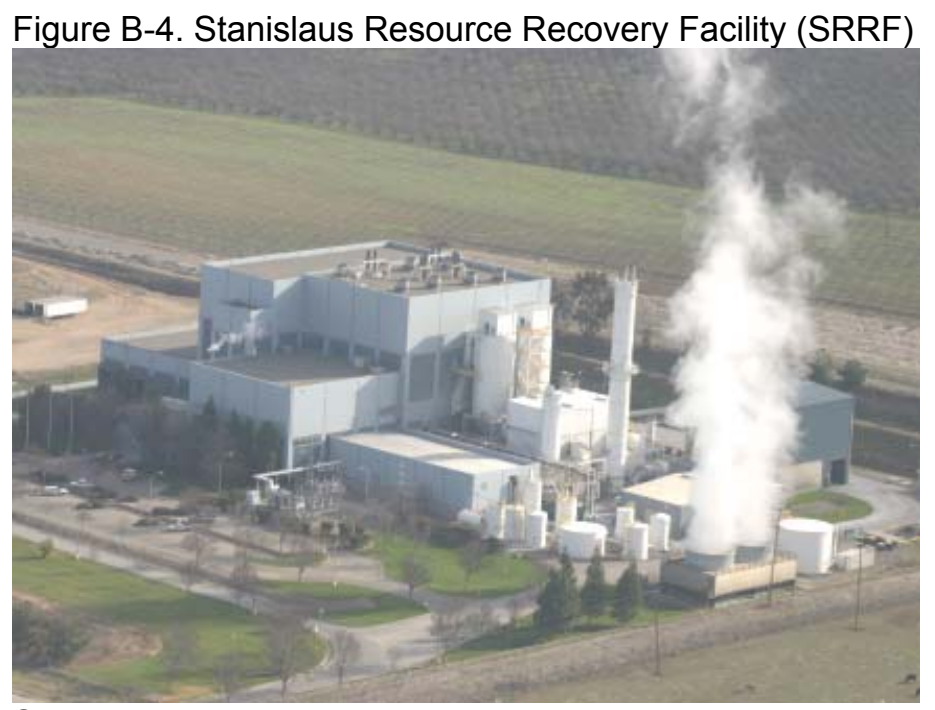

Source: http://www.stanislauswte.com/gallery.html\# 
Turlock Irrigation District (TID) Water \& Power, by taking advantage of water and gravity, generates electricity on its irrigation canal system through several small hydroelectric plants. Since 2003, the Turlock Irrigation District has provided $100 \%$ of the City's electricity demand. Turlock Irrigation District (TID) Water \& Power has a Renewable Portfolio goal of 20\% by 2017. With the Spring 2009 purchase of 137 megawatts of wind energy, TID has exceeded its goal.

TID's website lists energy efficiency tips, and offers several rebates related to energy efficiency and renewable energy:

- Spend $\$ 20$ on compact fluorescent light bulbs (CFL) and receive a $\$ 10$ rebate.

- Purchase new ENERGY STAR ${ }^{\circledR}$ appliances such as a clothes washer, refrigerator, or a room air conditioner and receive a rebate.

- TID offers help recycling old refrigerators and a $\$ 35$ rebate.

- Receive a \$20 rebate per tree when planting new shade trees to help cool the house in the summer.

- TID offers a rebate to offset a portion of the purchase cost for the installation of photovoltaic (PV) systems at your home.

- Sun Screen Rebate: TID offers a $\$ 1$ per square foot rebate to customers who cover their windows with heavy duty vinyl coated shade screens that block at least $80 \%$ of the sun's heat.

- $\$ 75$ rebate for purchasing and installing a whole house fan.

- Rebate of 40-cents per square foot for new residential homes that incorporate energy efficiency measures and meet the program requirements:

a. Builders must achieve a 35\% reduction in the structure's combined space heating, cooling, and water-heating energy.

b. Builders must achieve a $40 \%$ reduction in the building's air conditioning energy compared to specifications contained in the Title 24 of the state's Building Energy Efficiency Standards.

c. All appliances must be ENERGY STAR rated.

d. Independent on-site testing and inspections are required to verify the energy efficiency measures.

The Lakeside Oxidation Ditch, built in 1980, will soon be studied for suitability for energy efficiency upgrades.

According to the California Energy Commission (CEC), the Patterson area has substantial solar potential, with an estimated 5.37 Annual (kwh/sqm/day) PV Potential (April 2005, Figures $2 \& 3$, p.7). Stanislaus County, as a whole, has a PV Potential of 795,435 MWh/day and 140,965 MW (Table 1, p.8). The potential for residential buildings in Stanislaus County is estimated to have a PV Capacity of 2,518 kw (Table 2, p.10), while the potential for commercial buildings is estimated to have a PV Capacity of 198,513 kw (Table 3, p.11).

The community pool at the Patterson Aquatic Center utilizes solar heating.

CITY of PATTERSON JUNE 2009 SUSTAINABILITY PLAN 


\section{WATER}

Patterson is a member (Group l: Water Supplier) of the California Urban Water Conservation Council (CUWCC), which was created to increase efficient water use statewide through partnerships among urban water agencies, public interest organizations, and private entities. The City signed a Memorandum of Understanding pledging to develop and implement 14 comprehensive conservation Best Management Practices (BMPs).

The City lies within the Delta Mendota Groundwater Subbasin, as defined by the California Department of Water Resources. Water for agricultural use is provided by the surrounding irrigation districts that use surface supplies; some properties in agricultural production use groundwater. Agricultural irrigation generally uses surface supplies from the San Joaquin River and the west-side aqueducts. The City of Patterson does not use any surface water. According to the Villages of Patterson Development Plan EIR (2006), Patterson has historically satisfied all of its water demand from groundwater. According to the UWMP, there are two aquifers underlying the City: a lower confined zone, and an upper unconfined zone, separated by the thick, semi-impermeable Corcoran Clay layer. The City operates six groundwater wells, delivered to its customers after treatment, and continues to add wells for additional supply. The total production capacity of the six operational wells, according to the UWMP, is 6,700 gallons per minute (gpm), and there are back-up generators at all well sites in the event of a power failure. The City maintains 4.5 million gallons of storage and plans to construct additional storage for a total of at least 7.5 million gallons of storage capacity as system demands increase. The City also plans to investigate the possibility of aquifer storage and recovery to ensure longterm sustainability (UWMP).

According to the Villages of Patterson Development Plan EIR (2006), despite the new wells, the local groundwater table appears to remain stable, and the City has not seen measurable changes in the groundwater table or yield due to periods of low rainfall. Nevertheless, the City has adopted a Drought Contingency Plan.

The Water Planning Study (WPS), conducted in late 2005, recommended the conjunctive use of ground and surface water sources, providing the City with the best combination of quality, reliability, and affordability (UWMP). The City is currently working on the first phase of this program by completing "confirmation" work (i.e. acquiring surface water entitlements, pilot testing, supplemental water quality testing, property purchases for treatment facilities, and funding \& financing plans). The City is pursuing a possible regional strategy with Stanislaus County for a future water supply program. Negotiations with the Western Hills Water District about a potential partnership to increase the long-term water supply reliability for both agencies are on-going (UWMP).

The Water Division performs approximately one to two water leak repairs per week. Consistent with the Federal Safe Drinking Water Act (SDWA), the Water Supervisor releases an Annual Water Report, or Consumer 
Confidence Report, each year, providing information on drinking water quality.

The Environmental Programs Division of the Public Works Department urges residents, via the City website, to conserve water because "people use up our planet's fresh water faster than it can naturally be replenished." The City's message is that when you use water wisely, you help the environment, save energy, and save money. Numerous water-saving habits are explained on the website, including a Landscaping Watering Schedule, droughttolerant or lower water-use plants and grasses, efficient plumbing fixtures, repairing leaks, full loads of dishes and clothes, ultra-low-flush toilets, shorter showers, and more.

Municipal Code Chapter 15.48 prescribes planting and irrigation system design standards for new development, requires preparation of landscape and irrigation plans, and specifies that 90 percent of plants must be drought tolerant and underground irrigation must reduce water waste. Section 13.24.380 prohibits residential outdoor water use between 10am and 7pm, requires quick acting shutoff hose nozzles for car washing, establishes limitations on water use for newly planted lawns, and prescribes penalties for violation.

\begin{tabular}{|c|c|c|}
\hline & $\begin{array}{l}\text { If Address Ends in an Even } \\
\text { Number }\end{array}$ & $\begin{array}{l}\text { If Address Ends in an Odd } \\
\text { Number }\end{array}$ \\
\hline Monday & Watering Prohibited & $\begin{array}{c}\text { No Watering Between the } \\
\text { Hours } \\
\text { Of } 10 \mathrm{AM}-7 \mathrm{PM}\end{array}$ \\
\hline Tuesday & $\begin{array}{c}\text { Nowatering Between the } \\
\text { Hours } \\
\text { Of 10AM - 7PM }\end{array}$ & Watering Prohibited \\
\hline Wednesday & Watering Prohibited & $\begin{array}{c}\text { No watering Between the } \\
\text { Hours } \\
\text { Of } 10 \mathrm{AM}-7 \mathrm{PM}\end{array}$ \\
\hline Thursday & $\begin{array}{c}\text { No Watering Between the } \\
\text { Hours } \\
\text { Of } 10 \mathrm{AM}-7 \mathrm{PM}\end{array}$ & Watering Prohibited \\
\hline Friday & Watering Prohibited & $\begin{array}{c}\text { No watering Between the } \\
\text { Hours } \\
\text { Of } 10 \mathrm{AM}-7 \mathrm{PM}\end{array}$ \\
\hline Saturdav & $\begin{array}{c}\text { No Watering Between the } \\
\text { Hours } \\
\text { Of } 10 \mathrm{AM}-7 \mathrm{PM}\end{array}$ & Watering Prohibited \\
\hline Sunday & $\begin{array}{c}\text { Nowatering Between the } \\
\text { Hours } \\
\text { Of } 10 \mathrm{AM}-7 \mathrm{PM}\end{array}$ & $\begin{array}{c}\text { No Watering Between the } \\
\text { Hours } \\
\text { of } 10 \mathrm{AM}-7 \mathrm{PM}\end{array}$ \\
\hline
\end{tabular}

The City's Water Conservation patrol performs inspections to enforce water conservation. When water wastage is detected, the employee reports this to the Management Analyst, who is responsible for tracking these in a database. The first action taken is sending out notifications advising them of the City's Water Conservation program, which includes the City's watering schedule.

The Sewer Improvement Program lists helpful tips on the City website, such as using absorbent materials instead of a hose for outdoor spills, storing cleaning fluids indoors so leaks and spill cannot reach a storm drain, instructions on how to dispose of oils and greases, proper training of food facilities employees to prevent wastewater and food waste from entering storm drains, and the proper disposal of household hazardous waste (HHW) through the hazardous materials residential pick-up service. The website also warns residents against storm drain pollution because storm drains flow directly into river waters untreated by a sewage treatment plant.

The Stanislaus Resource Recovery Facility is a zero water discharge plant all wastewater generated on-site is treated and reused in the process (Covanta Energy website). 


\section{AIR QUALITY}

The tree-lined main thoroughfares and abundance of parks allow for carbon sequestration, reducing the amount of greenhouse gas emissions.

According to the San Joaquin Valley Air Pollution Control District (APCD) Annual Report on the District's Air Toxics Program (2007), there are no Air Toxics "Hot Spots" in the City of Patterson.

According to its website, the Stanislaus Resource Recovery Facility's emission control system exceeds expectations, controlling emissions "well below" EPA limits: lead 99.7\% removal, mercury 99.3\% removal, cadmium 98.8\% removal, hydrogen chloride $94.2 \%$ removal, and sulfur dioxide $91.2 \%$ removal.

\section{NATURAL RESOURCES}

The City has General Plan policies, under the Goal of "protect[ing] sensitive native vegetation and wildlife communities and habitat," that seek to preserve environmental resources. Please refer to the Policy Audit (tables) portion of the document.

\section{SuSTAINABLE ECONOMIC DEVELOPMENT}

Located in Stanislaus County, which ranks as one of the nations' top ten agricultural counties, producing in excess of $\$ 1$ billion in gross farm income, Patterson has a distinct advantage given its proximity to major markets, access to key ports, easy access to major highways and railways, and prime location in the world's most highly productive farming region. For every dollar of agricultural production in Stanislaus County, \$3.50 in economic activity is generated through processing, packaging, marketing, and retail. The City can easily position itself for sustainable economic development and local food purchasing. Agriculture and food processing industries are important to the area's economic success, but the growing commercial, industrial, and service sectors will provide for a diversified and sustainable economic base.

The City derives much of its economic vitality from agriculture, food processing, and distribution. It is also home to an expanding business park adjacent to Interstate 5, the Keystone Pacific Business Park, which has brought nearly 2,000 new jobs to the City.

Locating a business in Patterson strategically places companies near several of California's major markets. The area is within 90 miles of the San Francisco Bay Area, Silicon Valley, Sacramento, the Sierra Nevada Mountains, and California's central coast. Patterson is also about a 5-hour drive from Los Angeles. Two of California's major north-south highways intersect the area: Interstate 5 and Highway 99. All of these advantages add up to an outstanding location for business.

There is an existing association of businesses, the Patterson-Westley Chamber of Commerce. The City should partner with this organization to encourage and promote responsible and sustainable (green) businesses.

CITY of PATTERSON JUNE 2009 SUSTAINABILITY PLAN 
Stewart \& Jasper Orchards, family-owned in nearby Newman for more than 50 years, offers locally grown specialty nuts and dried fruits at its store located in Patterson in the commercial area adjacent to Interstate-5 - a great opportunity for a local grower to market its products.

\section{Challenges To IMPROVING SUSTAINABILITY}

Climate change is a global problem with local impacts on sustainability. Rising temperatures, longer, more frequent heat waves, and increased asthma and respiratory illnesses due to higher ozone levels (in an Air District already known to have nearly the worst air quality in the nation next to Los Angeles and Houston) all pose dangerous threats to Patterson residents. The agricultural industry is also expected to be "greatly disrupted" by a warmer climate, according to the San Francisco Climate Action Plan (ES-3).

Due to inaction on the part of the federal government for so many years, local action has come to be critical, with more than 935 U.S. cities (as of March 23, 2009) having chosen to participate in the Cities for Climate Protection (CCP) campaign, sponsored by Local Governments for Sustainability ICLEI. The new administration has already shown a commitment to investments in renewable energy and "green jobs," with the intent to combat climate change, but measures towards sustainability such as waste reduction and recycling have not been directly addressed yet. As such, local jurisdictions need to take the lead in planning and implementation. Given that Patterson will be adversely impacted by the effects of climate change, it is in the City's best interest to promote the concept of sustainability. The City of Patterson, its constituents, and business owners have the responsibility to act.

The following is a discussion of challenges facing the City of Patterson, organized by each of the focus areas of sustainability.

\section{LAND USE \& COMMUNITY DESIGN}

At the center of the City, a street grid pattern can be found, where the original roads of Patterson Colony were built based on the northwestsoutheast angle of the railroad (and now Highway 33), and the roundabout adapted from the cities of Washington, D.C. and Paris, France (Figure B-5). Moving outward, there is an obvious shift in the circulation network, from the grid pattern to that of the suburban paradigm, choc full of arterials, collector streets, and dead-end cul-de-sacs (shown below). Rampant growth, consisting mainly of generic subdivisions on the urban fringe, has far outpaced other valley cities, with a peak in 2005. Sprawl only exacerbates air pollution, traffic congestion, and an already-strained water supply. In order to achieve greater sustainability, the City needs to re-visit its roots, promoting compact urban form, smaller homes, and an intelligent circulation network to accompany it.

CITY of PATTERSON JUNE 2009 SUSTAINABILITY PLAN 


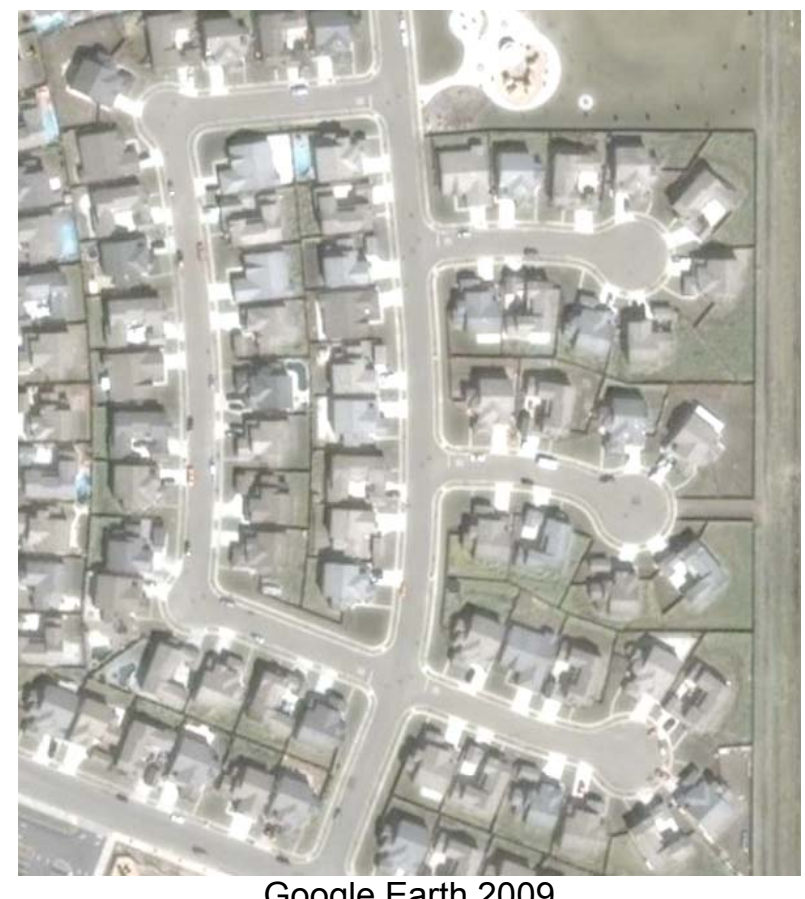

Google Earth 2009

Three alternatives were proposed as part of the General Plan Update. The Job Emphasis Alternative (Figure B-6) proposed a population of 50,000 in 2028 , and 72,000 in 2048, where the Ratio of Jobs to Housing would be $2.4^{*}$ in 2028 and $1.4 *$ in 2048. The Compact Development Alternative (Figure B7), recommended by the City's General Plan consultant, proposed a population of 47,000 for 2028 and 61,000 for 2048 in addition to more compact building design as an alternative to conventional, land-consumptive development. The Ratio of Jobs to Housing would be $2.0^{*}$ in 2028 and $1.4^{*}$ in 2048. In January 2009, the Planning Commission voted to recommend the third alternative (Figure B-8), designating land for more than triple the population from about 21,000 to 70,000 in 2028 and 83,000 in 2048. The jobs/housing ratio would be $1.30^{*}$ in 2028 and $1.26^{*}$ in 2048 .

*Incorporates a 30\% deduction for part-time jobs. 
Figure B-5. Current General Plan Land Use Map (January 2009)
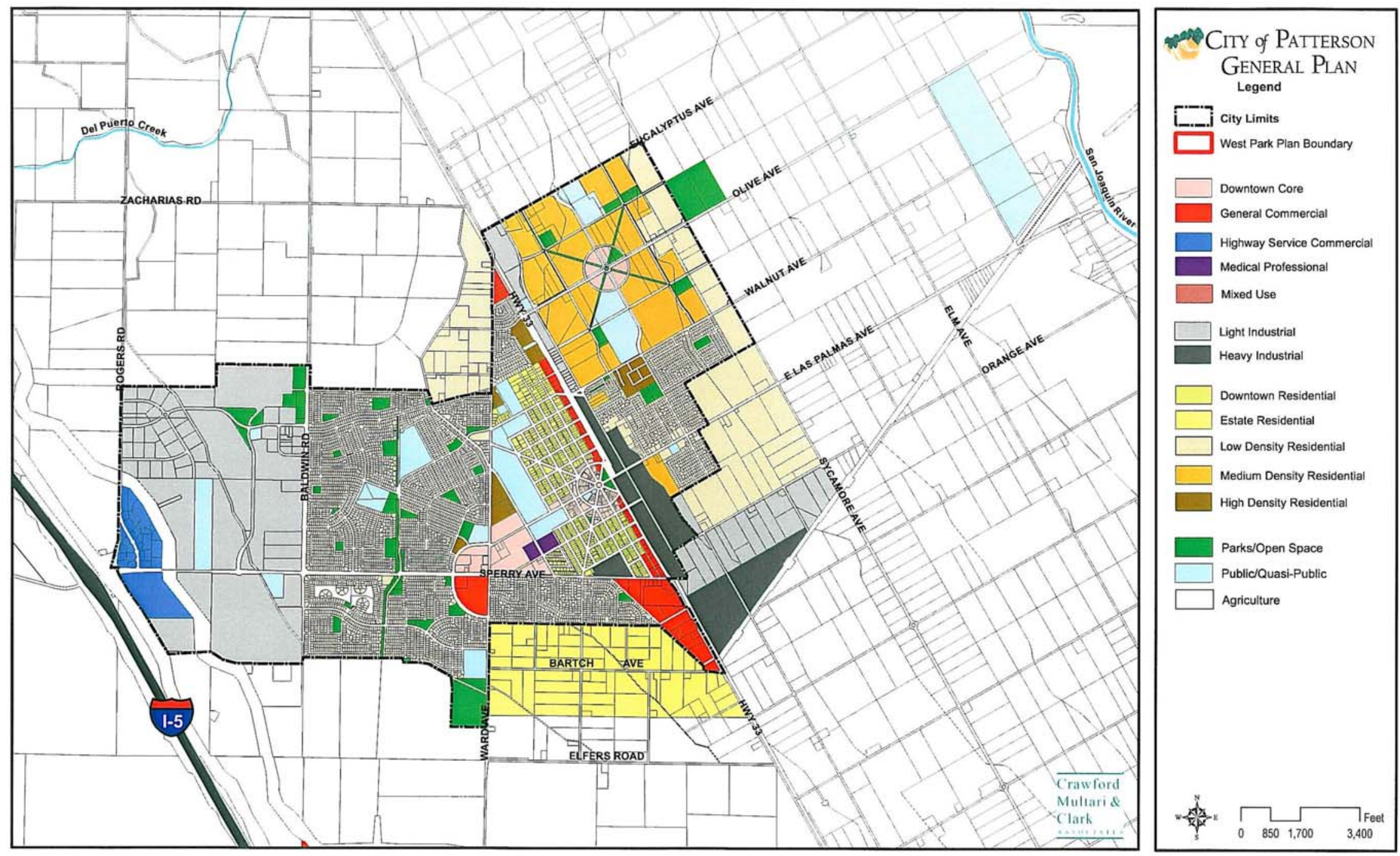

Source: Crawford Multari \& Clark Associates

City of PATTERSON JUNE 2009 SUSTAINABILITY PLAN 
Figure B-6. Job Emphasis Alternative (January 2009)

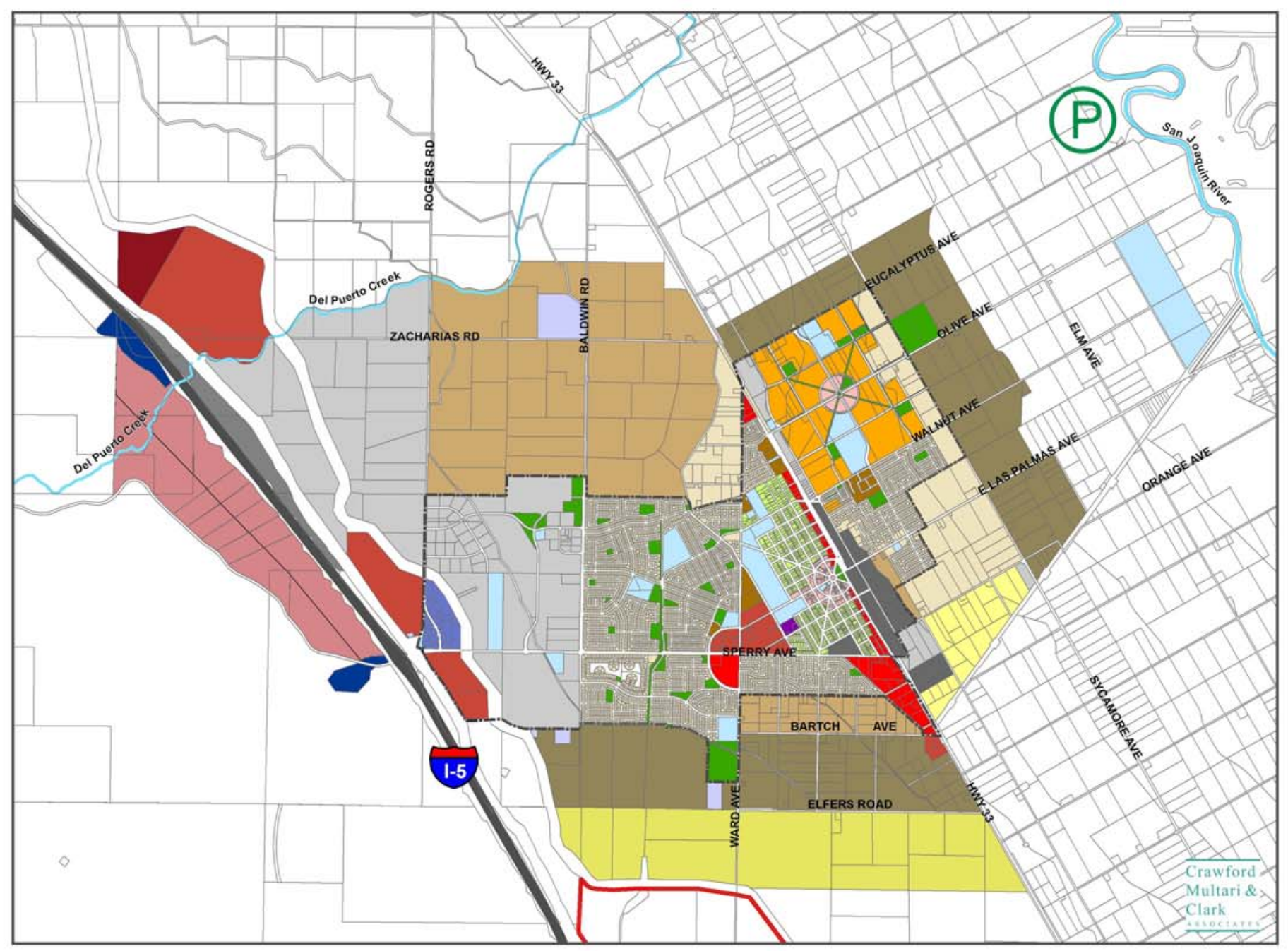

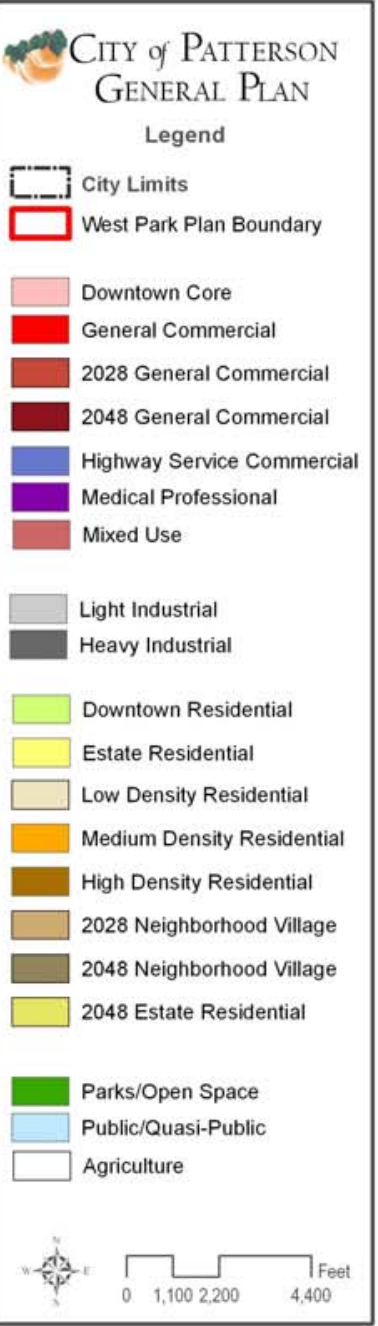

Source: Crawford Multari \& Clark Associates

City of PATTERSON JUNE 2009 SUSTAINABILITY PLAN 
Figure B-7. Compact Development Alternative (January 2009)

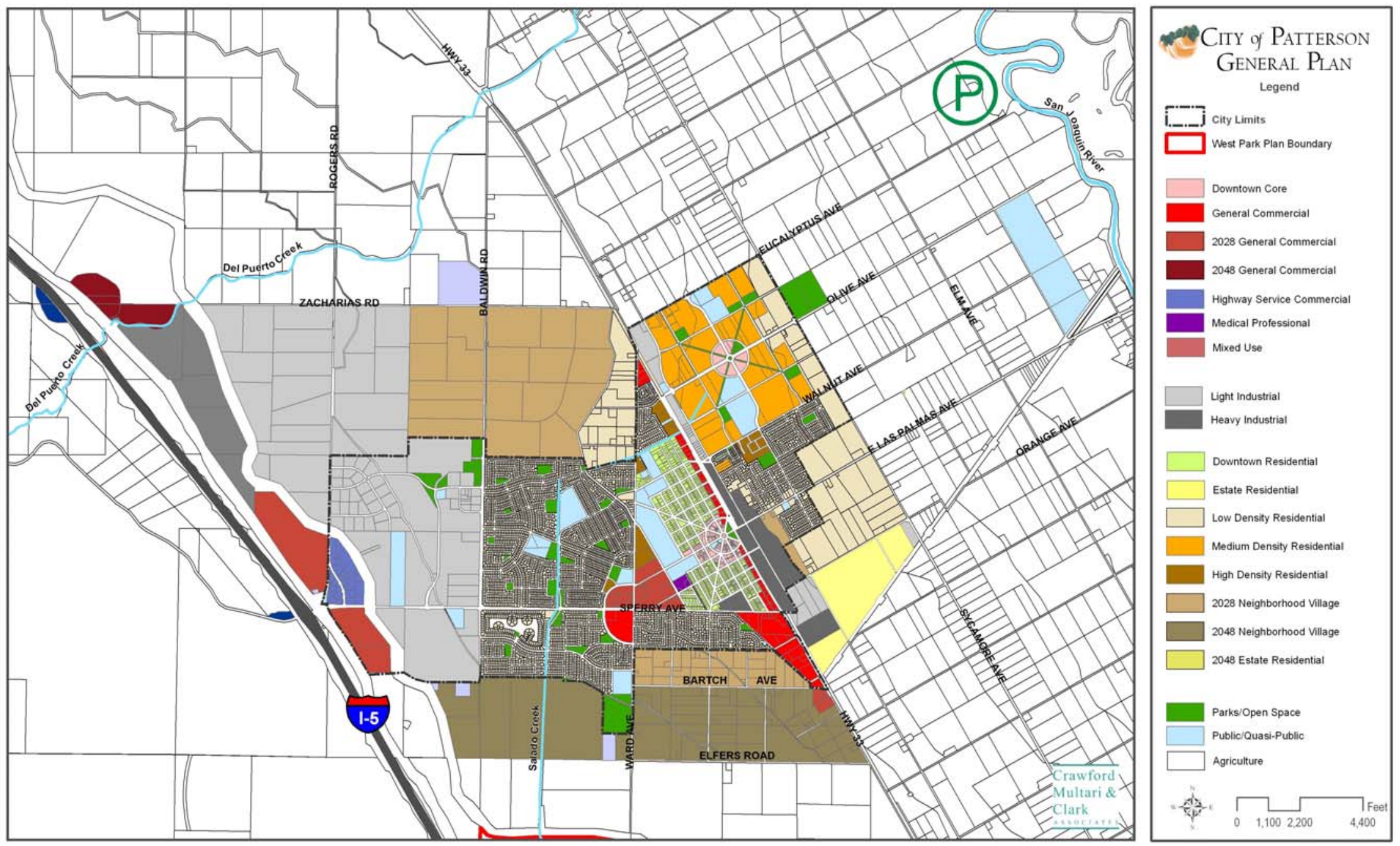

Source: Crawford Multari \& Clark Associates 
Figure B-8. Planning Commission Recommendation (January 2009)

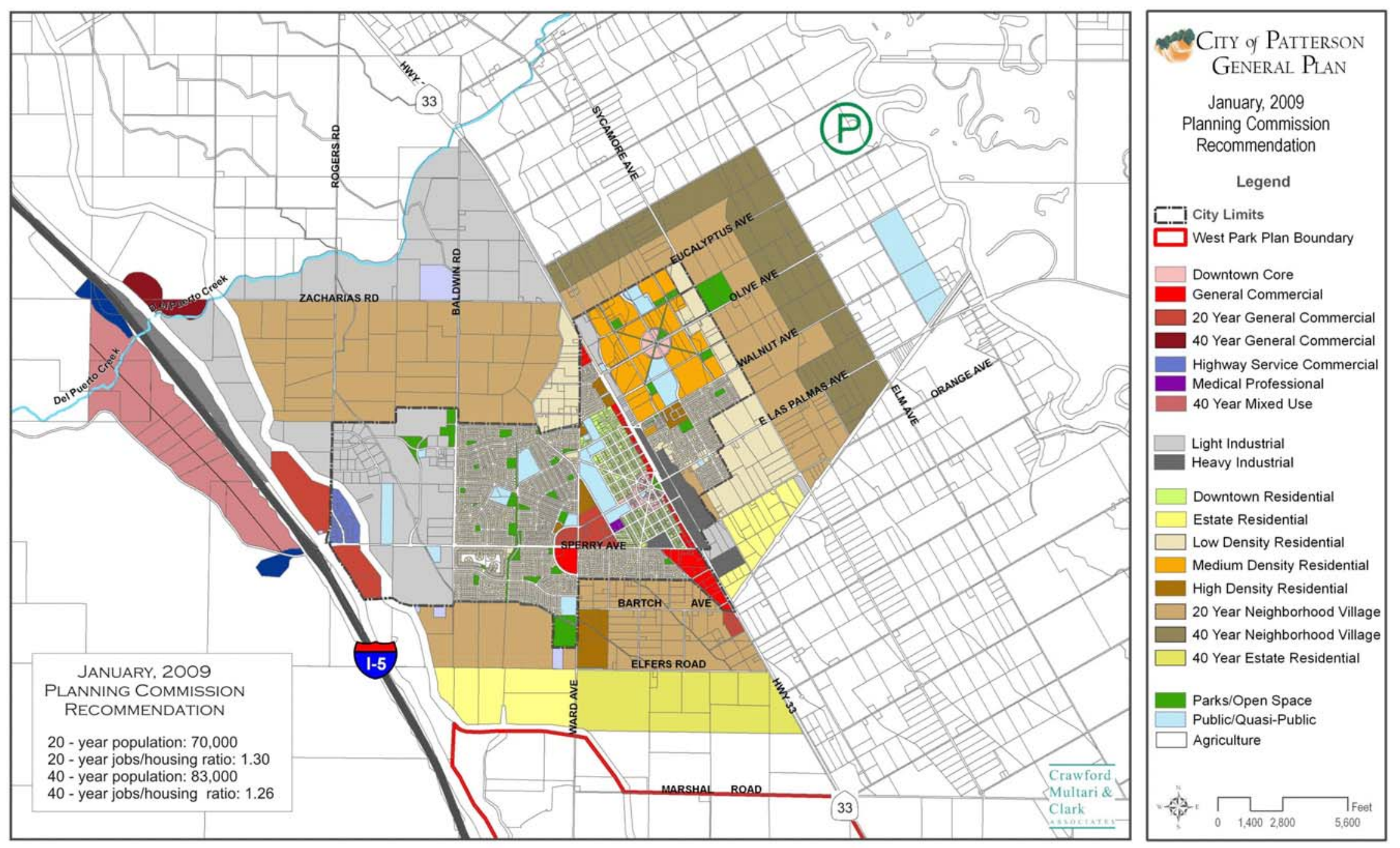

Source: Crawford Multari \& Clark Associates

City of PATTERSON JUNE 2009 SUSTAINABILITY PLAN 
Figure B-9 shows a number of parcels containing Prime Agricultural soils in the Patterson area that fall under the Land Conservation Act (Williamson Act) contracts. According to the State Department of Conservation, the Williamson Act enables governments to enter into contracts with private landowners for the purpose of restricting specific parcels of land to agricultural or related open space use. In return, landowners receive lower property tax assessments based on farming and open space uses, as opposed to full market value. Many of the Williamson Act lands directly surrounding Patterson, have filed for Non-Renewal of the contract. At the end of the nine-year Non-Renewal period, the contract is terminated and the land may then be developed for uses other than agriculture. In order to achieve compact urban form, an important facet of a sustainable community, it is imperative that outward expansion is minimized to the extent that it is possible to first develop vacant and underutilized land within the current City limits.

Under the State Important Farmland Mapping \& Monitoring Program (FMMP), agricultural land is rated according to soil quality and irrigation status. As shown in Figure B-10, by the California Department of Conservation Division of Land Resources Protection, the current Urban and Built-Up limits of the City are completely surrounded by Prime Farmland the best combination of physical and chemical features able to sustain longterm agricultural production (the best quality land). This land has the soil quality, growing season, and moisture supply needed to produce sustained high yields. Considering Patterson's projected future growth, the landowners of these surrounding lands in agriculture uses will increasingly be pressured to convert this farmland to urban development, resulting in the loss of Prime Farmland.

CITY of PATTERSON JUNE 2009 SUSTAINABILITY PLAN 
Figure B-9. Williamson Act Lands 2004
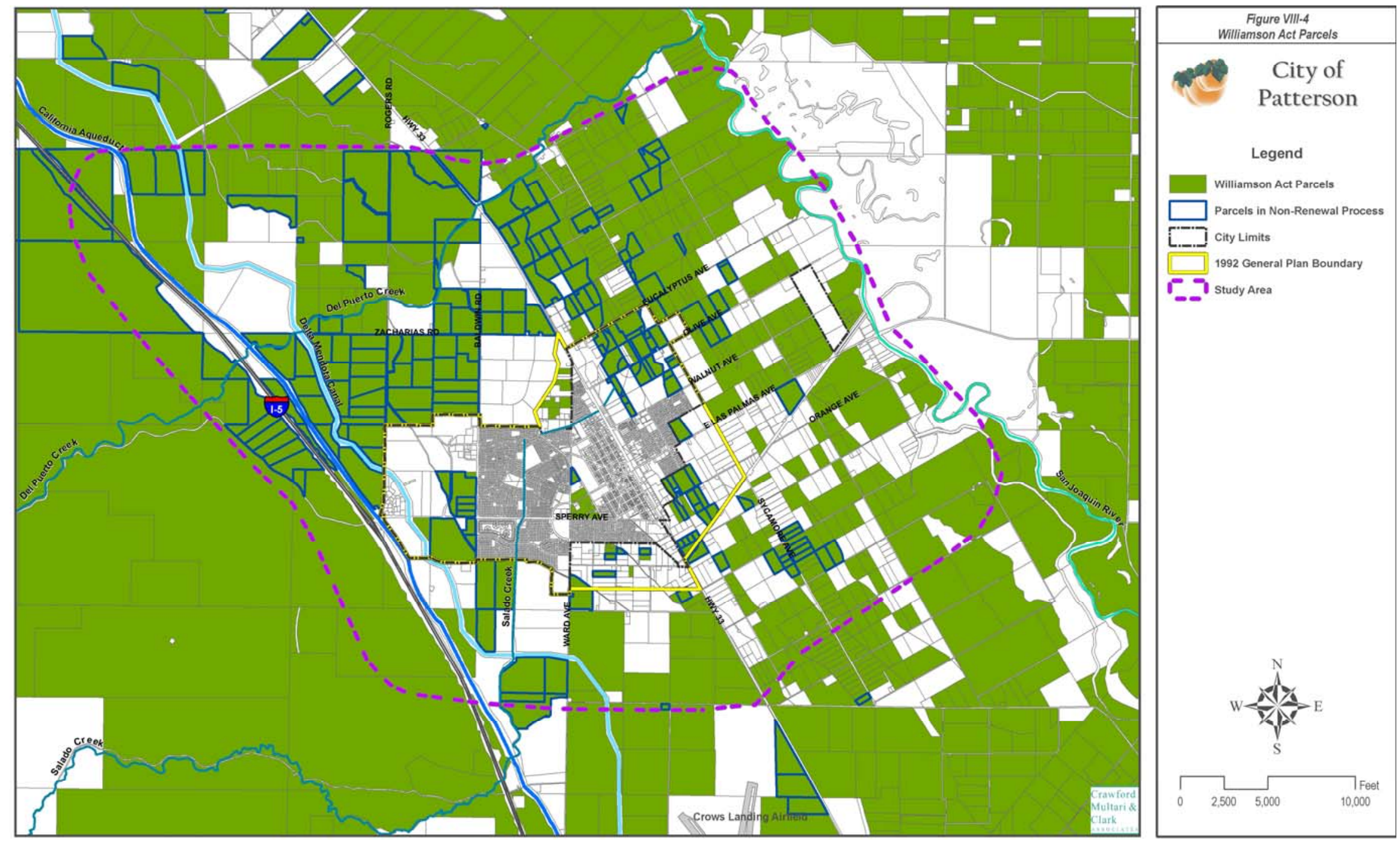

Source: Crawford Multari \& Clark Associates

City of PATTERSON JUNE 2009 SUSTAINABILITY PLAN

B-19 
Figure B-10. State Important Farmland 2004
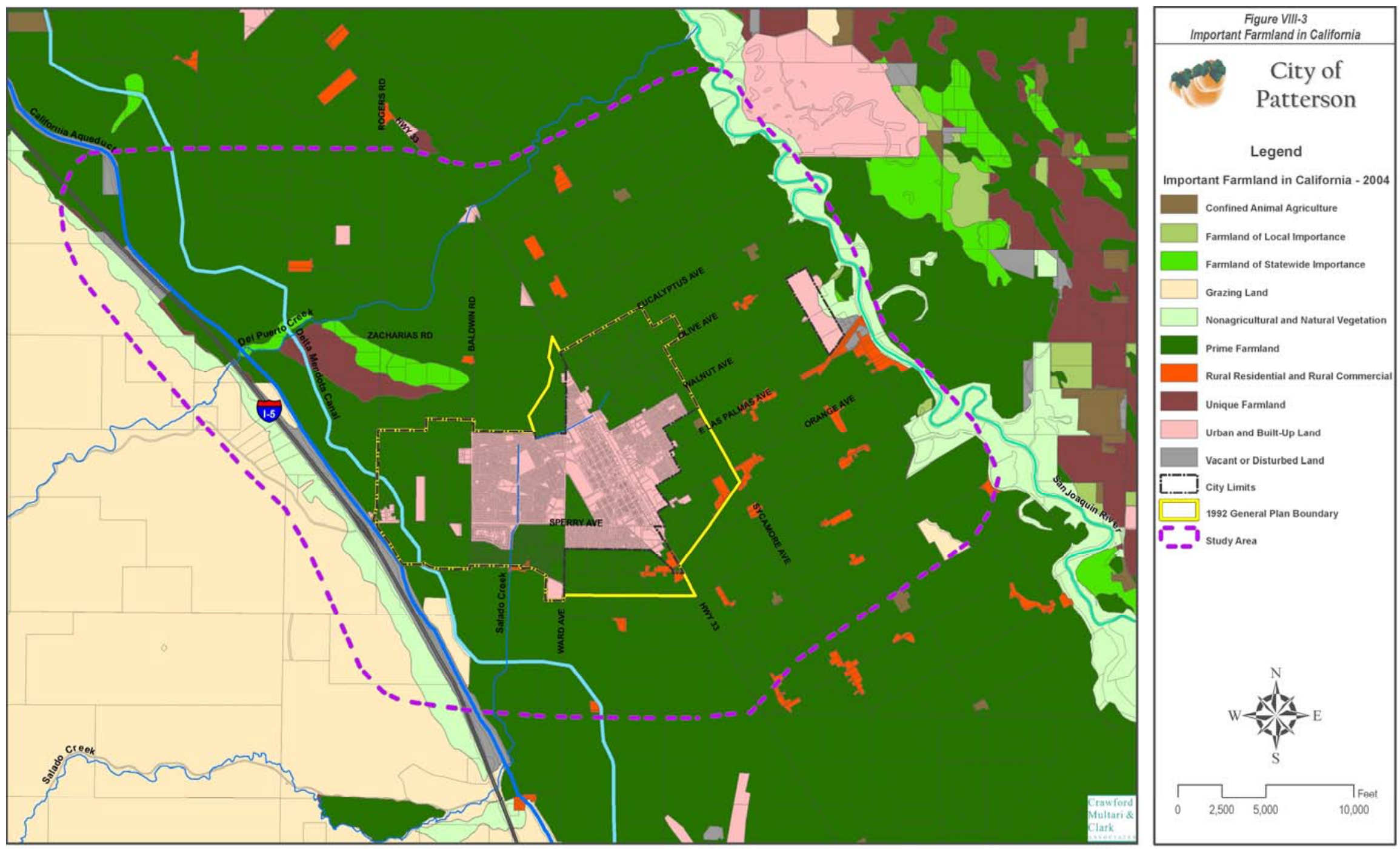

Source: Crawford Multari \& Clark Associates

CITY of PATTERSON JUNE 2009 SUSTAINABILITY PLAN 
Although the San Joaquin Valley has the overwhelming majority (55.4\%) of Prime Farmland in the state of California, urbanization continues to be a serious threat to the area (p.23), not to mention the state economy. The San Joaquin Valley region experienced the largest irrigated land losses between 2002 and 2004 (44\% of the statewide net decrease) (p.23). According to the California Farmland Conversion Report (December 2006), Stanislaus County had the tenth largest net decrease in irrigated farmland between 2000 and 2002, or 2,682 net acres (p.22). Stanislaus County ranked eighth overall in urbanization (in net acreage) in California between 2002 and 2004 (p.12), and had the second highest ratio (70\%) of prime farmland to urban land conversion in the entire state of California, after Tulare County (73\%) (p.l). Although the City has adopted the California Right-to-Farm Law, it does not have formal or informal greenbelt buffers.

The Estate Residential (ER) General Plan land use designation, applied to the area south of Poppy Avenue and east of Ward Avenue, is made up of mostly large-lot single family detached homes of a residential density between 1 du per half-acre and 1 du per 3 acres (p. I-2). This area serves as a buffer between more intense urban land uses and less intense agricultural uses. While this area mainly consists of ranchettes, what many consider contrary to the compact urban form required for pedestrian scale and the reduction of greenhouse gas emissions, it serves an equally valuable function in gradually separating incompatible land uses. With that said, the Estate Residential designation should be re-evaluated for its especially low density which does not match compact growth patterns typical of a sustainable community (p. I-2). If the designation remains, the City should consider a restriction in the form of a maximum lot coverage (building footprint) or a maximum floor-area-ratio (FAR) for the area designated Estate Residential.

The City has chosen to opt out of the adoption of strategies recommended by the San Joaquin Valley Regional Blueprint Planning Process, an innovative, eight county planning exercise intended to provide for sustainable growth through 2050. City officials prefer to "keep local control."

\section{TRANSPORTATION}

Shopping and services are generally located in the downtown core and at the intersection of Ward and Sperry Avenues, providing for an ideal bicycle and pedestrian-friendly environment, but the majority of residents drive from their homes to do their shopping. Moreover, jobs are generally not "within easy access" of most residents, although the West Patterson Business Park is easily accessible to new neighborhoods on the west side of town. According to the US Census, the average commute to work in 2000 was more than 41 minutes (one-way) for residents of Patterson, compared to 27 minutes for workers in the overall County of Stanislaus. In 2000, at least 70 percent drove a car alone to work, while only 24 percent carpooled (Figure B-11). Nearly 77 percent of workers (16 years of age and over), worked outside Stanislaus County (US Census). The Commuter Survey conducted in early 2004 revealed 79 percent of respondents naming a San Francisco Bay Area location (San Jose and Livermore were mentioned the most) as their commute destination and an average one-way commute time of almost 78 minutes.

CITY of PATTERSON JUNE 2009 SUSTAINABILITY PLAN 
Figure B-11. Means of Transportation to Work

\begin{tabular}{|l|c|c|}
\hline Drove a car alone: & $70 \%$ & 2,915 \\
\hline Carpooled: & $24 \%$ & 992 \\
\hline Bus: & $0 \%$ & 2 \\
\hline Subway (BART): & $0 \%$ & 7 \\
\hline Railroad: & $0 \%$ & 10 \\
\hline Bicycle: & $0 \%$ & 13 \\
\hline Walked: & $2 \%$ & 83 \\
\hline Other means: & $2 \%$ & 67 \\
\hline Worked at home: & $2 \%$ & 77 \\
\hline
\end{tabular}

Source: U.S. Census 2000

Unfortunately, regional transit by train is not a viable option for a daily commute. The nearest passenger rail station, Turlock/Denair Amtrak Station, is 21 miles east of Patterson, or roughly a 48-minute drive, according to Google Maps. The Tracy ACE (Altamont Commuter Express) Train Station, operated by Amtrak, is 26 miles northwest of Patterson, or a 31minute drive up Interstate- 5 .

Patterson Dial-a-Ride, operated by StaRT, offers curb-to-curb service by appointment for the elderly and disabled, in the Patterson area (Figure B-12). The hours of operation are $7 \mathrm{am}$ to $6 \mathrm{pm}$ Monday through Saturday, although the service is not offered between $12 \mathrm{pm}$ and $\mathrm{lpm}$. As such, the community is underserved when there are people who wish to use the service to get to an eatery or to another destination during the lunch hour.

Figure B-12. Patterson Dial-a-Ride Service Area

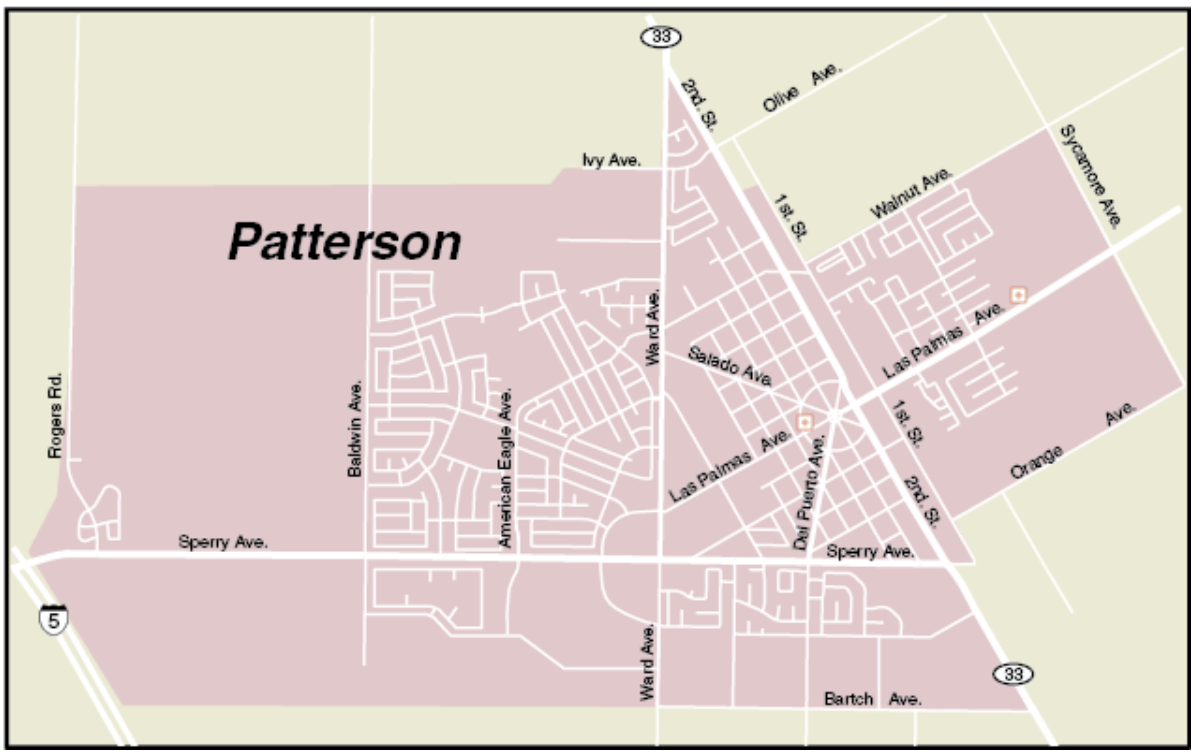

Source: http://www.srt.org (March 2009)

Goal 4 of the City of Patterson Bicycle Master Plan states that the City will work with employers to encourage incentives for employees who regularly 
commute by bicycle. As of June 2009, this program has not been implemented.

\section{WASTE REDUCTION \& RECYCLING}

Food waste is not recycled in Patterson (City website). While there is a recycling center in Patterson for other recyclables, batteries are to be dropped off at the Modesto Collection Facility, which is 17 miles (and 39 minutes) away. There is no ordinance requiring the majority of construction waste to be recycled.

\section{ENERGY}

The Building Maintenance Division has only one authorized position, reporting to the Urban Forestry supervisor, making it difficult for energy efficient measures to be implemented in a timely manner.

The Fleet Services Division has no hybrid or clean air vehicles.

There is no methane recovery system at the landfill or at the wastewater treatment plant to generate electricity.

\section{WATER}

According to the UWMP, nearly all water services in Patterson are metered on a monthly basis, but the City does not separately track different types of water use sectors (e.g. residential, commercial, industrial, landscaping, etc.). The UWMP recognizes that a new increasing block multi-tier rate structure based on volumetric use will likely encourage water conservation and reduce overall water demand, yet the City continues to enforce a fixed-rate structure.

According to the Non-Potable Water Master Plan and Feasibility Study (July 2008), traditional sources of water for Patterson and nearby communities (surface water from the California Aqueduct and Delta Mendota Canal, and local groundwater) are "limited and have quality challenges." Nearby San Joaquin River is not included as a surface water alternative because the Department of Health Services (DHS) does not consider it an acceptable source of drinking water, regardless of the level of treatment proposed, due to the "severely degraded" quality of the water (UWMP). Options for delivery of surface water include two man-made canals located west of Patterson: the California Aqueduct, part of the State Water Project, and the Delta Mendota Canal (DMC), part of the Federal Central Valley Project, but the canals have reached the end of their design life, and will require major reconstruction given the increasing frequency of outages, sometimes requiring repair lasting several weeks (UWMP). The DHS considers the California Aqueduct an acceptable source, but not the DMC.

From 1980 to 2005, Patterson's population increased by 413\%, but groundwater production increased by only $373 \%$ (UWMP). Competition for water among homes, farms, and the environment, will become more intense over time, especially given most projections indicating that less water will be

CITY of PATTERSON JUNE 2009 SUSTAINABILITY PLAN 
available in the future, due to climate change. The Plan/Study states that the cost of delivering water will "increase substantially" in the next fifteen to thirty years, and that Patterson will experience impacts more severely than most water purveyors. The City has no surface water entitlements, and groundwater quality and quantity are both limited. Securing reliable water for the existing General Plan is a challenging task by itself, but the City is currently undergoing a General Plan update reviewing potential scenarios that could expand the City by more than three times its current population by 2028 .

Water quality is a serious issue, more-so than the quantity of water supply, and the mineral content of the groundwater resource gets worse to the west. According to the Villages of Patterson Development Plan EIR (2006), the principal water quality concern with the groundwater is its high level of salinity. The City may be forced to provide treatment in the future, maybe even as early as 2009-2012, according to some studies, but the quality of the groundwater changes from year to year, making it difficult to establish a timeline. Even if the Villages of Patterson were not built and there was no additional growth approved within the present sphere of influence, the City would be expected to deplete the available supply of groundwater meeting Domestic Water Quality Standards at some point in the future (pg. III.J.14). The depletion would be accelerated should this project be developed. The City believes that, to meet demand, the City needs to start treating water, or acquire surface water from one of the three water districts in the next five to ten years (Patterson Irrigation District, Del Puerto Water District, and West Stanislaus Irrigation District). The Villages of Patterson Development Plan EIR (2006) affirms this belief, saying that at the time of the depletion of groundwater supply, the City would need to either transition to treatment of its groundwater sources or find an alternative water source.

The Non-Potable Water Master Plan and Feasibility Study (July 2008) found the City to have no surplus capacity in its water system, recommending a combination of water sources to maintain a more stable water program, likened to a balanced financial portfolio. This would "free up" existing water supply for new building permits without having to build new potable water production facilities that would be required otherwise. The Plan/Study found a non-potable system to be feasible, cost effective, highly reliable, and flexible.

According to the UWMP, summer water use is approximately 2.5 times more than in winter, due primarily to residential and commercial landscape irrigation. The Non-Potable Water Master Plan and Feasibility Study found that landscaping in Patterson uses a "tremendous" volume of water during warm periods of weather, with outdoor water use accounting for more than 50 percent of the total annual water use, and 2/3 of the maximum day demand. According to the Plan/Study, "estimated public and commercial landscaping that can be feasibly irrigated with a non-potable system is estimated to account for as much as 25 percent of the City's total annual water use, and over 40 percent of the peak month demands." Numerous local sources of water can be used for irrigation of landscaping, namely shallow groundwater, surface water from the Delta Mendota Canal, and reclaimed

City of PATTERSON JUNE 2009 SUSTAINABILITY PLAN 
wastewater. A dual water distribution system (potable and non-potable) receiving water from groundwater, surface water, and reclaimed wastewater - can provide non-potable irrigation of select public, semi-public, and commercial landscaping. At an estimated cost of $\$ 16.5$ million, implemented in phases, the non-potable water system can reduce the cost of drinking water to City residents, reduce drinking water demands substantially, allowing a reduction in the capacity of the proposed water treatment plant, and reduce the overall water supply program capital costs by up to $\$ 10$ million. With water supply becoming more limited, the City may eventually find that water for future growth is not available, regardless of its willingness to pay, but a non-potable water program can triple the number of water sources available to the City.

\section{AIR QUALITY}

For 2009, based on the scale below, Stanislaus County earned an Ozone Grade of "F" from the American Lung Association (i.e. between 2005-2007, there was an annual average of 45 Orange days: Unhealthy for Sensitive Groups and two Red days: Unhealthy).

$\begin{array}{lc}\text { OZONE } & \\ \text { Green } & 0.000-0.059 \mathrm{ppm} \text { Good } \\ \text { Yellow } & 0.060-0.075 \mathrm{ppm} \text { Moderate } \\ \text { Orange } & 0.076-0.095 \mathrm{ppm} \text { Unhealthy for Sensitive Groups } \\ \text { Red } & 0.096-0.115 \mathrm{ppm} \text { Unhealthy } \\ \text { Purple } & 0.116-0.374 \mathrm{ppm} \text { Very Unhealthy } \\ \text { Maroon } & >0.374 \mathrm{ppm} \text { Hazardous }\end{array}$

For 2009, based on the scale below, Stanislaus County earned a grade of "F" from the American Lung Association, ranking as the $20^{\text {th }}$ most polluted county in the nation, in terms of short-term $(24-\mathrm{hr})$ particle pollution, with an annual average of 32 Orange days: Unhealthy for Sensitive Groups, and two Red: Unhealthy days between 2005-2007 (http://www.stateoftheair.org). Modesto (20 miles northeast of Patterson) was ranked as the $17^{\text {th }}$ most polluted city in the nation, in terms of shortterm (24-hr) particle pollution (http://www.stateoftheair.org).

\section{Short-Term Particulate Pollution \\ Green from $0.0 \mu \mathrm{g} / \mathrm{m} 3$ to $15.4 \mu \mathrm{g} / \mathrm{m} 3 \mathrm{Good}$ \\ Yellow from $15.5 \mu \mathrm{g} / \mathrm{m} 3$ to $35.0 \mu \mathrm{g} / \mathrm{m} 3$ Moderate \\ Orange from $35.1 \mu \mathrm{g} / \mathrm{m} 3$ to $65.4 \mu \mathrm{g} / \mathrm{m} 3$ Unhealthy for Sensitive \\ Groups}

Red from $65.5 \mu \mathrm{g} / \mathrm{m}$ to $150.4 \mu \mathrm{g} / \mathrm{m}$ Unhealthy

Purple from $150.5 \mu \mathrm{g} / \mathrm{m}$ to $250.4 \mu \mathrm{g} / \mathrm{m}$ Very Unhealthy

Maroon greater than or equal to $250.5 \mu \mathrm{g} / \mathrm{m}$ Hazardous

The Urban Forestry Division does not have a goal for tree canopy coverage, nor is there a Tree Master Plan. 
Agricultural uses, including numerous dairy farms within a few miles of the City (ruminating cows are now widely known to emit harmful greenhouse gases nearly as much as trucks and cars), contribute towards the San Joaquin Valley's reputation as having the nation's worst air quality along with Los Angeles and Houston. According to a March 2006 Los Angeles Times article, smog in the San Joaquin Valley is responsible for $\$ 3.2$ billion annually in health costs and asthma and other respiratory illnesses abound.

Patterson has no higher education facilities, or an adult school. According to the Community Development Director, Modesto Junior College is considering construction of a satellite campus in Patterson (Personal interview, November 4, 2008). If this project comes to fruition, students will have a much shorter commute (Modesto is 20 miles away), reducing vehicle miles traveled (VMT) and greenhouse gas emissions, and improving air quality.

\section{NATURAL RESOURCES}

According to the Villages of Patterson Development Plan EIR (2006), agricultural and other human activity "long ago greatly modified" the natural communities that once existed along the west side of the San Joaquin Valley (III.H.1). With that said, there are still a "diverse assemblage of plants and wildlife." Land conversion for agricultural purposes and the predominance of crops that are unsuitable for foraging habitat have led to a loss of suitable habitat large enough to sustain Swainson's Hawks - a large soaring bird of open habitats once one of the most common birds of prey in California grasslands, but which populations have since declined by 90 percent since 1990 (III.H.7). However, the Swainson's Hawk (State Status: Threatened) is "presumed present" in the Villages of Patterson project area, despite not being observed during surveys (III.H.8). Suitable foraging habitat for the Northern Harrier (State Status: Species of Special Concern) was found to be present in Patterson (III.H.9). The Western Burrowing Owl (State Status: Species of Special Concern), although not found during surveys, may find suitable habitat prior to construction within the Villages of Patterson project site (III.H.9). The Loggerhead Shrike (State Status: Species of Special Concern) was found during the survey, due to suitable nesting and foraging habitat at the edge of the orchards and in some vegetation associated with residences (III.H.9). The Tricolored Blackbird (State Status: Species of Special Concern), while not found in surveys, is known to occasionally forage in agricultural habitats (III.H.10).

Concrete canals are now commonplace in, and surrounding Patterson. The original riparian habitat and associated biological resources, made up of both plants and animals, was long ago altered and displaced.

\section{SUSTAINABLE ECONOMIC DEVELOPMENT}

Generally, residents' everyday basic needs are met locally, including basic necessities such as groceries and products typically found in a pharmacy, but there is a great deal of "leakage" to other nearby cities such as Turlock or Modesto, for items such as clothing, electronics, and appliances.

CITY of PATTERSON JUNE 2009 SUSTAINABILITY PLAN 
According to the Department of Finance in 2008, the unemployment rate is 14.4\% (Labor Force Data For Sub-County Areas).

Known as the Apricot Capital of the World, sprawl from Patterson's original downtown core and earlier suburbs has "swallowed up" orchards, and the acreage devoted to apricots is declining. According to the president of the Apricot Producers of California in a July 2008 New York Times article, farmers blame the influx of dried apricots from Turkey, which sell for $\$ 1$ per pound compared to $\$ 3.50$ for California-grown, stealing 95 percent of the U.S. market. As a result, many farmers have sold out to developers or switched to less labor-intensive crops such as almonds. Despite the loss of local orchards that once produced 40 percent of the nation's apricots, the Apricot Fiesta, an agricultural and community festival which began in 1970, lives on each year in June.

\section{General Plan}

The Patterson General Plan, adopted on September 7, 2004, is made up of two documents: the Background Report and the Policy Document. The 2004 revision of the General Plan was not a comprehensive update, but intended to bring the Plan into conformance with amendments to State Law, and to re-affirm the Plan's goals, objectives, and policies. The City's consultant, Crawford Multari \& Clark Associates, is currently updating the General Plan, making this an ideal opportunity to incorporate principles of sustainability.

The City acknowledges that the General Plan "helps citizens to see their community as a complex system - a living entity that grows and responds to problems and opportunities" (p.l). The General Plan is also said to serve the following purposes:

- To establish within local government the capacity to analyze local and regional conditions and needs in order to respond effectively to the problems and opportunities facing the community;

- To identify the community's environmental, social, and economic goals;

- To record the local government's policies and standards for the maintenance and improvement of existing development and the location and characteristics of future development;

- To provide citizens with information about their community and with opportunities to participate in the local planning and decision-making process;

- To improve the coordination of community development and environmental protection activities among local, regional, state, and federal agencies; and

- To establish a basis for subsequent planning efforts, such as preparation of specific plans, redevelopment plans, and special studies, to deal with unique problems or areas in the community.

The last point mentions the General Plan's role in dealing with "unique problems," which includes climate change and the need to move towards sustainability to ensure the future prosperity of Patterson and its residents. Ultimately, it is the job of the City to "promote the health, safety, and welfare of the public" (p.2). 


\section{SUPPORTING GOALS, POLICIES \& PROGRAMS}

In each of the following sections, several policies are listed under each goal (with "Objectives" listed before each set of policies in the Housing Element), followed by "Implementation Programs." The proposed Sustainability Plan will seek to immediately follow each goal and objective with a specific and direct implementation measure. Implementation will be key to ensure successful progress toward sustainability. The following tables - organized by General Plan Element - list the existing City of Patterson General Plan goals, objectives, policies, and programs that support sustainability. The "Finding of Conformity" is listed with a brief description of what facet of sustainability is supported, e.g. compact urban form, jobs/housing balance, energy conservation, water conservation, waste reduction and recycling, carbon sequestration, and/or improved air quality.

\section{LAND USE}

A land use pattern that is compact, dense, and in close proximity to a mix of uses (e.g. residential and commercial) allows people to reduce their dependence on private automobiles and walk, bike, or use public transit to reach their destination. Compact and mixed-use development also increases the viability of public transit, something Patterson would like to improve. As a result, this trip reduction and decline in vehicle miles traveled (VMT) lowers the amount of greenhouse gas emissions and promotes greater public health through the increase in physical activity. The mere sight of others enjoying themselves walking and biking around town can encourage others to do the same, having a positive impact on businesses.

Table B-1 City of Patterson General Plan Land Use Element

\begin{tabular}{|l|l|}
\hline \multicolumn{1}{|c|}{ Goal, Objective, Policy, or Program } & \multicolumn{1}{c|}{ Finding of Conformity } \\
\hline $\begin{array}{l}\text { Policy I.A.1 The City shall seek to } \\
\text { preserve Patterson's traditional small- } \\
\text { town qualities and agricultural heritage, } \\
\text { while increasing its residential and } \\
\text { employment base. }\end{array}$ & $\begin{array}{l}\text { Supports compact \& mixed-use } \\
\text { development, agriculture, and a } \\
\text { jobs/housing balance. }\end{array}$ \\
& $\begin{array}{l}\text { Recommendation: Omit "seek to" for the } \\
\text { purpose of holding the City more } \\
\text { accountable in preserving said qualities. } \\
\text { Similarly, Policy I.A.2. states, the City } \\
\text { "should consider" the ratio of jobs to } \\
\text { dwelling units and progress towards } \\
\text { achieving standards. Such passive } \\
\text { language should be omitted. }\end{array}$ \\
\hline $\begin{array}{l}\text { Policy I.A.4. allows the City Council to } \\
\text { waive the requirements listed under } \\
\text { items A., B., and C. of Policy I.A.3. and } \\
\text { initiate proceedings for annexation } \\
\begin{array}{l}\text { upon finding that the project will result } \\
\text { in a significant public benefit which } \\
\text { may include: }\end{array}\end{array}$ & $\begin{array}{l}\text { Supports permanent protection of sensitive } \\
\text { habitat and agricultural land. }\end{array}$ \\
$\begin{array}{l}\text { D. The permanent protection of } \\
\text { sensitive resources such as } \\
\text { habitat for special status plants or } \\
\text { animal species or productive } \\
\text { agricultural land. }\end{array}$ & $\begin{array}{l}\text { protected in perpetuity as part of a project, } \\
\text { the requirement can be waived. }\end{array}$ \\
\hline
\end{tabular}


Table B-1 City of Patterson General Plan Land Use Element

\begin{tabular}{l}
\hline Goal, Objective, Policy, or Program \\
\hline Policy I.A.5. The City shall link the rate \\
of growth in Patterson to the provision \\
of adequate services and \\
infrastructure, including schools. The \\
City shall, through specific plans and/or \\
planned unit development plans for \\
major projects, ensure that growth \\
occurs in an orderly fashion and in \\
pace with the expansion of public \\
facilities and services.
\end{tabular}

Policy I.A.6. addresses the promotion of a "reasonable citywide balance between new employment-generating development and housing development."

Policy I.A.8. The City shall promote growth that reinforces the downtown and its western extension as the geographic and economic center of Patterson.

Policy I.B.2. Generally, higher density housing shall be located in areas served by the full range of urban services, preferably along collector and arterial streets, within walking distance of shopping areas.

Policy I.C.2. Major new commercial development shall be concentrated in a single node near the existing downtown, which complements, rather than competes with, the existing downtown.

Policy I.C.4. The City shall continue to pursue incentives to attract commercial and industrial development.
Supports economic importance of downtown.

Analysis: With more explicit specificity, this policy can help facilitate high-density, compact growth in the downtown to promote an economically viable, pedestrian and bicycle-friendly environment.

Supports compact urban form and walking.

Analysis: This policy should address "local" streets (as shown on the Circulation Plan Diagram) within the downtown core, an area where higher density housing should be encouraged, regardless of the street classification. The intent should be to proactively encourage and/or require high density residential uses, especially mixeduse (with residential above and commercial below), in this area.

Supports concentrated commercial uses near the downtown, and sustainable economic development.

Analysis: This policy promotes sustainable economic development by avoiding competition with the existing downtown, implicitly promoting a bicycle and pedestrian-friendly environment, but because it specifies "major" new commercial development, the policy does not explicitly encourage commercial development of a smaller scale, something to reconsider.

Recommendation: The Sustainability Plan will be more explicit of such incentives, and establish a "green business" program to allow existing businesses to reinvent themselves, broaden their consumer base, and provide for a new marketing mechanism to support local business.

Recommendation: See recommendation 
Table B-1 City of Patterson General Plan Land Use Element

\begin{tabular}{|c|c|}
\hline Goal, Objective, Policy, or Program & Finding of Conformity \\
\hline $\begin{array}{l}\text { local business groups and } \\
\text { associations, such as the Patterson- } \\
\text { Westley Chamber of Commerce, to } \\
\text { promote Patterson businesses. }\end{array}$ & after Policy I.C.4. \\
\hline $\begin{array}{l}\text { Policy I.C.6. The City shall encourage } \\
\text { efforts to attract major commercial and } \\
\text { office tenants to Patterson. }\end{array}$ & $\begin{array}{l}\text { Recommendation: This policy has } \\
\text { successfully been implemented to date, but } \\
\text { the City should consider encouraging } \\
\text { unique, smaller, locally-owned commercial } \\
\text { and office uses. }\end{array}$ \\
\hline $\begin{array}{l}\text { Policy I.E.4. The City shall promote } \\
\text { the development of clean industries } \\
\text { that do not create problems or pose } \\
\text { health risks associated with water and } \\
\text { air pollution or potential leaks or spills. }\end{array}$ & $\begin{array}{l}\text { Supports clean industries. } \\
\text { Recommendation: The City should be } \\
\text { more proactive in implementing this policy, } \\
\text { attracting clean energy firms, promoting } \\
\text { responsible manufacturers, and the like. }\end{array}$ \\
\hline $\begin{array}{l}\text { Policy I.F.2. The City shall promote } \\
\text { the clustering of public and quasi- } \\
\text { public uses such as schools, parks, } \\
\text { libraries, child care facilities, and } \\
\text { community activity centers. }\end{array}$ & $\begin{array}{l}\text { Supports compact urban form. Implies } \\
\text { ability to walk or bike. } \\
\text { Analysis: The implementation of this policy } \\
\text { contributes to a bicycle and pedestrian- } \\
\text { friendly community. The T.W. Patterson } \\
\text { Sports Complex built on the southern edge } \\
\text { of town is not consistent with the above } \\
\text { policy, but the Community Center currently } \\
\text { under construction adjacent to the existing } \\
\text { Community Pool is consistent with this } \\
\text { policy. Schools and parks are all located } \\
\text { within close proximity to each other, and the } \\
\text { Stanislaus County - Patterson Branch } \\
\text { Library is located in the downtown area. }\end{array}$ \\
\hline $\begin{array}{l}\text { Implementation Program I.4. The } \\
\text { City shall monitor the city's population } \\
\text { growth on an annual basis and shall } \\
\text { institute a growth management } \\
\text { program if necessary to ensure that the } \\
\text { city does not exceed the population } \\
\text { limits set forth in Policy I.A.2. }\end{array}$ & Supports growth management. \\
\hline $\begin{array}{l}\text { Implementation Program I.6. The } \\
\text { City shall develop an economic } \\
\text { development plan/employment } \\
\text { strategy to identify strategies to attract } \\
\text { new commercial development and } \\
\text { industry to Patterson. The City shall } \\
\text { create a citizen committee to assist the } \\
\text { City in this effort. }\end{array}$ & $\begin{array}{l}\text { Supports jobs/housing balance and } \\
\text { sustainable economic development } \\
\text { (implicitly). }\end{array}$ \\
\hline
\end{tabular}

\section{HOUSING}

If the City were to require the use of green building techniques, this policy would support mixed-use, infill development, energy efficiency, water conservation, and improve air quality, while creating jobs. Patterson, with the majority of its residents commuting outside its borders to work, is in dire need of a jobs/housing balance. The City must work to attract more jobs. 
Table B-2. City of Patterson General Plan Housing Element

\begin{tabular}{l}
\hline Goal, Objective, Policy, or Program \\
\hline Policy II.B.3. Encourage developers to \\
employ innovative or alternative \\
construction methods to reduce \\
housing costs and increase housing \\
supply.
\end{tabular}
supply.
Objective II.C.1. Provide information to profit and non-profit developers and other housing providers on available vacant land.

\section{Objective II.C.2. Provide opportunities} for mixed-use developments.

Policy II.C.1. Monitor and update the inventory of vacant lands. Implementation Program II.21. Continue to track development on all vacant land in the City on a quarterly basis.

Policy II.C.2. To ensure the development of housing that has, to the extent possible, a support structure of shopping, services, and jobs within easy access.

\begin{tabular}{l}
\multicolumn{1}{c|}{ Finding of Conformity } \\
Supports green building techniques \\
(implicitly).
\end{tabular}

Recommendation: This policy should be refined by further clarifying the meaning of "innovative" and "alternative" construction methods to encourage green building techniques (e.g. innovative materials and energy efficient, sustainable design), or simply provide examples, with more of an emphasis on minimizing the impact on the environment and providing for a safe and healthy indoor living space. Less of an emphasis should be placed on increasing housing supply.

Supports infill development.

Recommendation: The City has maps available. These should be marketed to developers.

Supports mixed-use development.

Analysis: The policy should specify the general location(s) of such development (e.g. downtown).

Supports infill development.

Analysis: May reduce the potential for greenfield development.

Supports compact urban form, jobs/housing balance, and growth supported by infrastructure and services.

Analysis: Shopping and services are generally located in the downtown core, providing for an ideal bicycle and pedestrian-friendly environment, but the majority of residents drive from their homes to do their shopping. Because the majority of people commute long distances to work, jobs are generally not "within easy access" for most residents.

Policy II.D.3. Promote energy conservation activities in all residential neighborhoods.

Supports energy conservation.

Recommendation: The proposed Sustainability Plan will define methods of energy conservation and specify how they will be promoted.

Policy II.F.1. Achieve a jobs/housing $\quad$ Supports jobs/housing balance. balance.

Analysis: Although the ratio of jobs to housing has improved from 2004 to 2009 , this policy has not yet been fully implemented. In order to achieve greater sustainability by reducing greenhouse gas 
Table B-2. City of Patterson General Plan Housing Element

\begin{tabular}{|c|c|}
\hline Goal, Objective, Policy, or Program & Finding of Conformity \\
\hline & $\begin{array}{l}\text { emissions and vehicle miles traveled } \\
\text { (VMT), and promote bicycling and walking, } \\
\text { the City needs to attract more jobs to } \\
\text { Patterson. }\end{array}$ \\
\hline $\begin{array}{l}\text { Implementation Program II.6. } \\
\text { Arrange an annual meeting with } \\
\text { representatives of the Board of } \\
\text { Realtors, and other community } \\
\text { development agencies to track regional } \\
\text { development. }\end{array}$ & $\begin{array}{l}\text { Supports regional planning. } \\
\text { Analysis: More than simply "tracking" } \\
\text { regional development, the City needs to be } \\
\text { more proactively involved at a regional } \\
\text { level. For example, the City should consider } \\
\text { being an active partner in the regional } \\
\text { Blueprint planning process in San Joaquin } \\
\text { Valley. A single meeting once per year is } \\
\text { insufficient, especially given recent state } \\
\text { legislation that will directly affect, namely } \\
\text { AB } 32 \text { Global Warming Solutions Act and } \\
\text { SB } 375 \text {. }\end{array}$ \\
\hline $\begin{array}{l}\text { Implementation Program II.22. } \\
\text { Encourage development of well } \\
\text { planned and designed projects that } \\
\text { provides for the development of } \\
\text { compatible residential, commercial, } \\
\text { industrial, institutional, or public uses } \\
\text { within a single project or neighborhood } \\
\text { by continuing to provide incentives } \\
\text { such as allowing higher building } \\
\text { intensities, reduced parking } \\
\text { requirements, reduced set-back and } \\
\text { yard requirements, allow for a higher } \\
\text { building height, and greater floor area } \\
\text { ratios in these zones. Other incentives } \\
\text { that the City will offer is to offer } \\
\text { reduced residential fees or only charge } \\
\text { commercial fees for the mixed use } \\
\text { project. }\end{array}$ & $\begin{array}{l}\text { Supports high density, mixed-use, compact } \\
\text { urban form. } \\
\text { Recommendation: This policy should } \\
\text { specifically promote walking and biking. }\end{array}$ \\
\hline $\begin{array}{l}\text { Implementation Program II.23. } \\
\text { Encourage development of mixed use } \\
\text { projects to maximize residential } \\
\text { components by modeling future } \\
\text { projects on past office/residential mix } \\
\text { use accomplishments. }\end{array}$ & Supports mixed-use development. \\
\hline $\begin{array}{l}\text { Implementation Program II.25. } \\
\text { Promote orderly growth through the } \\
\text { establishment and adherence to } \\
\text { Policies that focuses annexations and } \\
\text { growth to one area at a time to allow } \\
\text { for timely and efficient use of } \\
\text { infrastructure and resources. }\end{array}$ & Supports growth management. \\
\hline $\begin{array}{l}\text { Implementation Program II.27. } \\
\text { Supply energy conservation } \\
\text { awareness brochures in all public } \\
\text { meeting places. }\end{array}$ & $\begin{array}{l}\text { Supports energy conservation. } \\
\text { Analysis: The "Timing" is listed as being } \\
\text { "June 2005," making it unclear whether } \\
\text { such brochures will regularly be supplied or } \\
\text { only during that month. The implementation } \\
\text { should occur on an ongoing basis. }\end{array}$ \\
\hline
\end{tabular}




\section{TRANSPORTATION AND CIRCULATION}

Availability of public transit is minimal at best in Patterson, requiring riders to Dial-a-Ride. The City of Patterson is fortunate to be a size conducive to pedestrian and bicycle activity, but still most people drive to each of their daily destinations. The City needs to strive to make these alternative modes of transportation more attractive, and attract more jobs within City limits to reduce the need for a long commute to the San Francisco Bay Area.

Table B-3. City of Patterson General Plan Transportation And Circulation Element

\begin{tabular}{|c|c|}
\hline Goal, Objective, Policy, or Program & Finding of Conformity \\
\hline $\begin{array}{l}\text { Goal III.A. To create and maintain a } \\
\text { roadway network that will ensure the } \\
\text { safe and efficient movement of people } \\
\text { and goods throughout the city. }\end{array}$ & Supports efficient transportation. \\
\hline $\begin{array}{l}\text { Policy III.A.1. Street design and } \\
\text { access standards shall provide for safe } \\
\text { and efficient movement of goods and } \\
\text { people. Restrictive traffic control } \\
\text { measures (such as channelization, } \\
\text { street closures, and prohibition of } \\
\text { some traffic movements) shall be used } \\
\text { where appropriate to promote traffic } \\
\text { safety and efficient traffic operation. }\end{array}$ & Supports efficient transportation. \\
\hline $\begin{array}{l}\text { Policy III.A.2. The City shall endeavor } \\
\text { to maintain a Level of Service "D", as } \\
\text { defined by the } 2000 \text { Highway Capacity } \\
\text { Manual or subsequent revisions, on all } \\
\text { streets and intersections within the city. }\end{array}$ & $\begin{array}{l}\text { Supports efficient transportation. } \\
\text { Analysis: The City should aim for a Level } \\
\text { of Service (LOS) "C" - which is considered } \\
\text { typical, with less of an emphasis on Level } \\
\text { of Service, and more of an emphasis on } \\
\text { "complete streets" that equally } \\
\text { accommodate bicyclists and pedestrians, } \\
\text { and not just motor vehicles. }\end{array}$ \\
\hline $\begin{array}{l}\text { Policy III.A.4. Neighborhood streets } \\
\text { shall be designed, where feasible, to } \\
\text { discourage unsafe traffic speeds. }\end{array}$ & $\begin{array}{l}\text { Supports walking and biking (implicitly) } \\
\text { Analysis: This policy should specifically } \\
\text { encourage the use of landscaped } \\
\text { roundabouts, or traffic circles, for traffic } \\
\text { calming and additional public open space } \\
\text { for carbon sequestration, public safety, and } \\
\text { aesthetics. The City already has numerous } \\
\text { traffic circles, and seeks to provide more, } \\
\text { but has no General Plan policy supporting } \\
\text { them. }\end{array}$ \\
\hline $\begin{array}{l}\text { Policy III.A.8. Industrial and } \\
\text { commercial development shall be } \\
\text { planned so that truck access through } \\
\text { residential areas is avoided. }\end{array}$ & $\begin{array}{l}\text { Supports safety for biking and walking } \\
\text { (implicitly). } \\
\text { Analysis: While this policy will result in a } \\
\text { safer, more comfortable environment for } \\
\text { both bicyclists and pedestrians, the City } \\
\text { should consider policies directly narrowing } \\
\text { the width of existing roads to make streets } \\
\text { safer and more conducive to walking. }\end{array}$ \\
\hline $\begin{array}{l}\text { Goal III.B. To promote and maintain } \\
\text { public and private transit systems that } \\
\text { are responsive to the needs of } \\
\text { Patterson residents. }\end{array}$ & $\begin{array}{l}\text { Supports efficient transportation and } \\
\text { private/public transit. }\end{array}$ \\
\hline Policy III.B.1. The City shall work to & Supports efficient transportation and \\
\hline
\end{tabular}


Table B-3. City of Patterson General Plan Transportation And Circulation Element

\begin{tabular}{|c|c|}
\hline Goal, Objective, Policy, or Program & Finding of Conformity \\
\hline $\begin{array}{l}\text { assure that West Side Dial-a-Ride } \\
\text { service is responsive to local needs. }\end{array}$ & private/public transit. \\
\hline $\begin{array}{l}\text { Policy III.B.2. The City shall work with } \\
\text { the County to maintain a van/minibus } \\
\text { transportation system tailored to the } \\
\text { needs of the elderly and disabled, } \\
\text { which can be expanded in the future. }\end{array}$ & Supports public transit for the elderly. \\
\hline $\begin{array}{l}\text { Policy III.B.3. The City shall } \\
\text { encourage the establishment of private } \\
\text { taxi service in Patterson. }\end{array}$ & Supports the ability to not own a car. \\
\hline $\begin{array}{l}\text { Goal III.C. To promote increased } \\
\text { efficiency in automobile use. }\end{array}$ & $\begin{array}{l}\text { Supports efficient transportation for } \\
\text { automobiles only. }\end{array}$ \\
\hline $\begin{array}{l}\text { Policy III.C.1. The City shall } \\
\text { encourage and support programs } \\
\text { which will increase ridesharing. }\end{array}$ & $\begin{array}{l}\text { Supports ridesharing and the ability to not } \\
\text { own a car. }\end{array}$ \\
\hline $\begin{array}{l}\text { Policy III.C.2. The City shall cooperate } \\
\text { with Caltrans in the development of } \\
\text { park-and-ride facilities near Interstate } \\
5 .\end{array}$ & Supports park-and-ride. \\
\hline $\begin{array}{l}\text { Policy III.C.3. The City shall organize } \\
\text { a voluntary ride-share coordination } \\
\text { system for commuters. }\end{array}$ & Supports ridesharing for commuters. \\
\hline $\begin{array}{l}\text { Policy III.D.1. To the extent feasible, } \\
\text { the City shall provide for separation of } \\
\text { residential and other noise-sensitive } \\
\text { land uses from major roadways to } \\
\text { reduce noise and air pollution impacts. }\end{array}$ & $\begin{array}{l}\text { Supports separation of land uses to } \\
\text { improve air quality. }\end{array}$ \\
\hline $\begin{array}{l}\text { Goal III.E. To promote } \\
\text { intergovernmental communication and } \\
\text { cooperation concerning transportation- } \\
\text { related issues. }\end{array}$ & $\begin{array}{l}\text { Supports regional and state transportation } \\
\text { planning (implicitly). }\end{array}$ \\
\hline $\begin{array}{l}\text { Policy III.E.1. The City shall continue } \\
\text { to participate in state, regional, and } \\
\text { local transportation planning efforts to } \\
\text { ensure coordination of the expansion } \\
\text { and improvement of the region's } \\
\text { transportation system. }\end{array}$ & $\begin{array}{l}\text { Supports regional and state transportation } \\
\text { planning. }\end{array}$ \\
\hline $\begin{array}{l}\text { Policy III.E.2. The City shall continue } \\
\text { to develop formal and informal lines of } \\
\text { communication between adjacent } \\
\text { jurisdictions to ensure cooperation in } \\
\text { the development of transportation } \\
\text { systems that cross jurisdictional } \\
\text { boundaries. }\end{array}$ & Supports regional transportation planning. \\
\hline $\begin{array}{l}\text { Policy III.F.5. The City shall encourage } \\
\text { business owners and employees of the } \\
\text { existing downtown, including } \\
\text { employees of the City of Patterson, to } \\
\text { park their vehicles at more distant } \\
\text { locations to free up parking spaces } \\
\text { within the downtown. }\end{array}$ & $\begin{array}{l}\text { Supports a park-once strategy for shoppers } \\
\text { who wish to walk. }\end{array}$ \\
\hline $\begin{array}{l}\text { Goal III.G. To promote pedestrian and } \\
\text { bicycle travel as alternatives to } \\
\text { automobile use. }\end{array}$ & $\begin{array}{l}\text { Supports walking and biking instead of } \\
\text { driving. }\end{array}$ \\
\hline $\begin{array}{l}\text { Policy III.G.1. The City shall create } \\
\text { and maintain a safe and convenient }\end{array}$ & $\begin{array}{l}\text { Supports walking and biking paths instead } \\
\text { of automobile use. }\end{array}$ \\
\hline
\end{tabular}


Table B-3. City of Patterson General Plan Transportation And Circulation Element

\begin{tabular}{l|l|}
\hline Goal, Objective, Policy, or Program & \multicolumn{1}{|c|}{ Finding of Conformity } \\
\hline system of pedestrian and bicycle & \\
pathways that encourages walking or & \\
bicycling as an alternative to driving. & \\
New development shall be required to & \\
pay its share of the costs for & \\
development of this pathway system. & \\
\hline Policy III.G.2. The City shall establish & Supports local and regional bicycle path \\
a safe and convenient network of & network. \\
identified bicycle routes connecting & \\
residential areas by the shortest & \\
possible routes with recreation, & \\
shopping, and employment areas & \\
within the city. The City shall cooperate & \\
with surrounding jurisdictions in & \\
designing and implementing an area- & \\
wide bikeway system. & \\
\hline Policy III.G.3. Bicycle routes shall & \\
emphasize paths separated from & Supports off-street bicycle paths and on- \\
vehicle traffic to the maximum extent \\
possible, but shall also include bicycle & \\
lanes within public streets. The City & \\
shall limit on-street bicycle routes to & \\
those streets where the available & \\
roadway width and traffic volumes \\
permit safe coexistence of bicycle and \\
motor vehicle traffic.
\end{tabular}

\section{Public FACILITIES AND SERVICES}

The clustering of public and semi-public facilities is crucial for trip reduction. Solid waste reduction, reuse, composting, and recycling are vital to sustainability, as is the need for water conservation. Open space, parks, and trails, offer opportunities for carbon sequestration and physical activity, improving air quality and public health. 
Table B-4. City of Patterson General Plan Public Facilities And Services Element

\begin{tabular}{|l|r}
\hline Goal, Objective, Policy, or Program & Finding of Conformity \\
\hline Policy IV A 1. The City shall continue & Supports water resource planning.
\end{tabular}

to use groundwater as a source of domestic water for the city. The City shall also pursue, as expeditiously as possible, acquisition of surface water rights to supplement its water supply in order to accommodate projected water demand and provide for water supply security.

Policy IV.A.2. The City shall expand and develop water treatment, distribution, and storage facilities to accommodate the needs of existing and planned development.

Policy IV.A.3. The City shall not approve any new development without the demonstrated assurance of an adequate water supply to support such development.

Policy IV.A.4. The City shall coordinate, to the extent feasible, with other agencies involved in water resource development in the region.

Policy IV.A.5. To minimize the need for the development of new water sources and facilities and to minimize sewer treatment needs, the City shall promote water conservation both in City operations and in private development.

Policy IV.A.6. The City shall systematically replace or repair old, leaking water lines.

Goal IV.D. To provide for the collection and disposal of solid waste while minimizing the generation of waste.

Policy IV.D.1. The City shall study and actively pursue methods of solid waste recycling and reuse, including source separation, with the goal of reducing its solid waste generation by 25 percent by 2005 and 50 percent by the year 2010 .

Policy IV.D.3. The City shall maintain close contact with the Stanislaus County Public Works Department concerning the City's continuing use of the Fink Road Waste-to-Energy Plant and its capacity projections. Goal IV.I. To promote efficiency, convenience, and harmonious relationships in the siting of public facilities.

Supports adequate water supply.

Supports adequate water supply.

Supports regional water resource planning.

Supports water conservation.

The City encourages water conservation on its website under its Environmental Programs \& Resources within the Public Works Department.

Supports water conservation.

Supports minimizing waste.

Supports recycling, reuse, and solid waste reduction.

Analysis: Giving policies specific timelines for achievement is highly effective under good leadership.

Supports continued use of waste-to-energy plant.

Supports clustering of public facilities (implicitly). 
Table B-4. City of Patterson General Plan Public Facilities And Services Element

\begin{tabular}{|c|c|}
\hline Goal, Objective, Policy, or Program & Finding of Conformity \\
\hline $\begin{array}{l}\text { Policy IV.I.2. Utility company rights- } \\
\text { of-way shall be considered for use as } \\
\text { public or private open space, trails, } \\
\text { parkland, or other compatible } \\
\text { recreational uses. }\end{array}$ & $\begin{array}{l}\text { Supports additional open space, trails, } \\
\text { parks, and recreation. }\end{array}$ \\
\hline $\begin{array}{l}\text { Policy IV.I.4. The City shall promote } \\
\text { the clustering of public and quasi- } \\
\text { public facilities such as schools, } \\
\text { parks, libraries, child care facilities, } \\
\text { and community activity centers. The } \\
\text { City shall promote joint-use of public } \\
\text { facilities, and agreements for sharing } \\
\text { costs and operational responsibilities } \\
\text { among public service providers. }\end{array}$ & $\begin{array}{l}\text { Supports clustering of public and quasi- } \\
\text { public facilities. } \\
\text { This indirectly promotes biking and walking } \\
\text { as an alternative to driving. }\end{array}$ \\
\hline $\begin{array}{l}\text { Implementation Program IV.8. The } \\
\text { City shall prepare, adopt, and } \\
\text { implement a Source Reduction and } \\
\text { Recycling Program which includes the } \\
\text { following components: } \\
\text { - Waste Characterization } \\
\text { - Source Reduction } \\
\text { - Recycling } \\
\text { - Somposting } \\
\text { - Edid Waste Facility Capacity } \\
\text { - Information } \\
\text { - Sunding } \\
\text { - Housecial Waste } \\
\text { Hould Hazardous Waste }\end{array}$ & Supports source reduction and recycling. \\
\hline
\end{tabular}

\section{RECREATIONAL AND Cultural SERVICES}

Open space, parks, and trails, offer opportunities for carbon sequestration and bicycle \& pedestrian activity, reducing vehicle trips and improving air quality and public health. Historic preservation minimizes the need for new building and promotes adaptive reuse.

Table B-5. City of Patterson General Plan Recreational And Cultural Services Element

\begin{tabular}{|l|l|}
\hline Goal, Objective, Policy, or Program & \multicolumn{1}{|c|}{ Finding of Conformity } \\
\hline $\begin{array}{l}\text { Policy V.A.5. Neighborhood parks } \\
\text { shall be integrated into, and become } \\
\text { focal points of, new residential } \\
\text { neighborhoods. Pedestrian } \\
\text { accessibility shall be emphasized. }\end{array}$ & $\begin{array}{l}\text { Supports additional parks and pedestrian } \\
\text { accessibility. }\end{array}$ \\
\hline $\begin{array}{l}\text { Policy V.A.7. The City shall pursue } \\
\text { joint-use of school facilities as a high } \\
\text { priority for the development of new } \\
\text { park and recreational facilities, } \\
\text { especially for after-school activities. }\end{array}$ & $\begin{array}{l}\text { Supports joint-use of facilities, minimizing } \\
\text { the need for additional facilities, and trip } \\
\text { reduction. }\end{array}$ \\
\hline $\begin{array}{l}\text { Policy V.A.11. The City shall } \\
\text { emphasize the use of drought-tolerant } \\
\text { and drought-resistant landscaping in } \\
\text { the development of City parks. }\end{array}$ & Supports water conservation. \\
\hline
\end{tabular}


Table B-5. City of Patterson General Plan Recreational And Cultural Services Element

\begin{tabular}{l|l|}
\hline Goal, Objective, Policy, or Program & \multicolumn{1}{|c|}{ Finding of Conformity } \\
\hline $\begin{array}{l}\text { Policy V.A.14. The City shall pursue } \\
\text { the development of a citywide network } \\
\text { of pedestrian and bicycle pathways. }\end{array}$ & Supports bicycle and pedestrian pathways. \\
\hline $\begin{array}{l}\text { Policy V.B.2. The City shall promote } \\
\text { the inclusion of private outdoor and } \\
\text { indoor recreation facilities in large } \\
\text { commercial/industrial projects as a } \\
\text { benefit for employees and as a means } \\
\text { of reducing demand on public } \\
\text { facilities. }\end{array}$ & $\begin{array}{l}\text { Supports trip reduction, public health, and } \\
\text { reduction of the obesity rate (implicitly). }\end{array}$ \\
\hline $\begin{array}{l}\text { Policy V.D.2. The City shall maintain } \\
\text { a historic district in the downtown area } \\
\text { and along East Las Palmas Avenue } \\
\text { and develop standards for } \\
\text { preservation and rehabilitation of } \\
\text { historic structures and compatible infill } \\
\text { development. }\end{array}$ & $\begin{array}{l}\text { Supports historic preservation, adaptive } \\
\text { reuse, and infill development. }\end{array}$ \\
\hline
\end{tabular}

\section{NATURAL RESOURCES}

Agricultural preservation is vital to sustainable economic development, healthy eating options, the promotion of infill development, and discouragement of sprawling land use patterns. The preservation of open space, as well as sensitive habitat and species, offers opportunities for carbon sequestration and bicycle \& pedestrian activity, reducing vehicle trips and improving air quality and public health. Species and habitat protection also ensures a diverse and sustainable ecosystem. Tree canopy coverage is important for carbon sequestration, improved air quality and public health, shade, and aesthetic appeal.

Table B-6. City of Patterson General Plan Natural Resources Element

\section{Goal, Objective, Policy, or Program \\ Goal VI.B. To promote the productivity of agricultural land surrounding Patterson and to prevent the premature conversion of agricultural land to urban uses.}

Policy VI.B.1. The City shall support the continuation of agricultural uses on lands designated for urban uses until urban development is imminent.

Policy VI.B.2. The City shall encourage the County to retain agricultural uses on lands surrounding the Planning Area and on lands within the Planning Area pending their annexation to the City or development by mutual agreement with the County.

Policy VI.B.3. The City shall support tax and economic incentives, at both the local and state levels, to enhance the economic competitiveness of
Finding of Conformity

Supports agricultural preservation.

Supports agricultural preservation.

Supports agricultural preservation.

Supports an agricultural economy.


Table B-6. City of Patterson General Plan Natural Resources Element

\begin{tabular}{|c|c|}
\hline Goal, Objective, Policy, or Program & Finding of Conformity \\
\hline agriculture. & \\
\hline $\begin{array}{l}\text { Policy VI.B.4. The City shall allow and } \\
\text { encourage activities that support local } \\
\text { agriculture such as farmers' markets, } \\
\text { on-site sale of produce, and special } \\
\text { events promoting local agricultural } \\
\text { products. }\end{array}$ & $\begin{array}{l}\text { Supports an agricultural economy through } \\
\text { marketing techniques. } \\
\text { Note: There currently is no farmer's market } \\
\text { in the City of Patterson. }\end{array}$ \\
\hline $\begin{array}{l}\text { Policy VI.B.6. The City shall adopt a } \\
\text { right-to-farm ordinance. }\end{array}$ & Supports farm preservation. \\
\hline $\begin{array}{l}\text { Policy VI.B.7. The City shall support } \\
\text { economic programs established by the } \\
\text { County for farm preservation. }\end{array}$ & Supports farm preservation. \\
\hline $\begin{array}{l}\text { Policy VI.B.8. Where necessary to } \\
\text { promote planned city growth, the City } \\
\text { shall encourage development of those } \\
\text { agricultural lands that are already } \\
\text { compromised by adjacent urban } \\
\text { development or contain property } \\
\text { required for the extension of } \\
\text { infrastructure or other public facilities, } \\
\text { before considering urban development } \\
\text { on agricultural lands that are not } \\
\text { subject to such urban pressures. }\end{array}$ & $\begin{array}{l}\text { Allows development of agricultural land, but } \\
\text { supports agricultural preservation. }\end{array}$ \\
\hline $\begin{array}{l}\text { Goal VI.C. To protect sensitive native } \\
\text { vegetation and wildlife communities } \\
\text { and habitat. }\end{array}$ & $\begin{array}{l}\text { Supports the protection of natural } \\
\text { resources. }\end{array}$ \\
\hline $\begin{array}{l}\text { Policy VI.C.1. The City shall } \\
\text { encourage and support development } \\
\text { projects and programs that enhance } \\
\text { public appreciation and awareness of } \\
\text { the natural environment. }\end{array}$ & Supports community outreach. \\
\hline $\begin{array}{l}\text { Policy VI.C.2. The City shall support } \\
\text { state and federal laws and policies to } \\
\text { preserve populations of rare, } \\
\text { threatened, and endangered species } \\
\text { by ensuring that development does not } \\
\text { adversely affect such species or by } \\
\text { fully mitigating adverse effects. }\end{array}$ & Supports species and habitat protection. \\
\hline $\begin{array}{l}\text { Policy VI.C.3. Unless there are } \\
\text { significant, overriding considerations, } \\
\text { the City shall not approve projects that } \\
\text { would cause unmitigatible impacts on } \\
\text { rare, threatened, or endangered } \\
\text { wildlife or plant species. }\end{array}$ & Supports species and habitat protection. \\
\hline $\begin{array}{l}\text { Policy VI.C.4. The City shall support } \\
\text { and participate in local and regional } \\
\text { attempts to restore and maintain viable } \\
\text { habitat for endangered plant and } \\
\text { animal species. }\end{array}$ & Supports species and habitat protection. \\
\hline $\begin{array}{l}\text { Policy VI.C.5. The City shall work with } \\
\text { the California Department of Fish and } \\
\text { Game in identifying a regional area or } \\
\text { areas suitable for Swainson's Hawk } \\
\text { habitat; this land should be designated } \\
\text { as a potential mitigation land bank for } \\
\text { impacts on existing habitat for these } \\
\text { species. }\end{array}$ & Supports species and habitat protection. \\
\hline
\end{tabular}


Table B-6. City of Patterson General Plan Natural Resources Element

\begin{tabular}{|c|c|}
\hline Goal, Objective, Policy, or Program & Finding of Conformity \\
\hline $\begin{array}{l}\text { Policy VI.C.7. The City shall promote } \\
\text { the use of native plants, especially } \\
\text { valley oaks, for landscaping roadsides, } \\
\text { parks, and private properties. }\end{array}$ & Supports water conservation. \\
\hline $\begin{array}{l}\text { Goal VI.D. To promote and, to the } \\
\text { extent possible, improve air quality in } \\
\text { Patterson and the region. }\end{array}$ & Supports improved air quality. \\
\hline $\begin{array}{l}\text { Policy VI.D.1. The City shall work with } \\
\text { the San Joaquin Unified Air Pollution } \\
\text { Control District in an effort to ensure } \\
\text { the earliest practicable attainment and } \\
\text { subsequent maintenance of federal } \\
\text { and state ambient air quality } \\
\text { standards. }\end{array}$ & Supports improved air quality. \\
\hline $\begin{array}{l}\text { Policy VI.D.2. The City shall utilize the } \\
\text { CEQA process to identify and avoid or } \\
\text { mitigate potentially significant air } \\
\text { quality impacts of new development. } \\
\text { The CEQA process shall also be } \\
\text { utilized to ensure early consultation } \\
\text { with the San Joaquin Unified Air Basin } \\
\text { Authority concerning air quality issues } \\
\text { associated with specific development } \\
\text { proposals. }\end{array}$ & Supports improved air quality. \\
\hline $\begin{array}{l}\text { Policy VI.D.4. Major intersections shall } \\
\text { be designed to minimize long vehicle } \\
\text { delays which result in carbon } \\
\text { monoxide (CO) "hot spots." }\end{array}$ & Supports improved air quality. \\
\hline $\begin{array}{l}\text { Policy VI.D.6. The City shall promote } \\
\text { expansion of employment opportunities } \\
\text { within Patterson to reduce commuting } \\
\text { to areas outside Patterson. }\end{array}$ & $\begin{array}{l}\text { Supports a jobs/housing balance, reduction } \\
\text { of long commutes, and improved air quality. }\end{array}$ \\
\hline $\begin{array}{l}\text { Implementation VI.2. The City shall } \\
\text { monitor the research and literature of } \\
\text { agricultural-based public and private } \\
\text { organizations in assessing methods to } \\
\text { protect agricultural lands at the urban } \\
\text { fringe, including the use of } \\
\text { conservation easements } \\
\text { (Responsibility: Planning Department. } \\
\text { Time Frame: Ongoing). }\end{array}$ & Supports agricultural preservation. \\
\hline
\end{tabular}

\section{City Design, StRucture, AND Aesthetics}

Compact growth is essential for agricultural preservation, trip reduction, and increased pedestrian and bicycle activity, supporting improved air quality, public health, and a viable downtown.

Table B-7. City of Patterson General Plan City Design, Structure, And Aesthetics Element

Goal, Objective, Policy, or Program Finding of Conformity

\begin{tabular}{l|l} 
Goal VIII.A. To promote the & Supports compact growth and agriculture.
\end{tabular} development of a coherent and distinctive physical form and structure 
Table B-7. City of Patterson General Plan City Design, Structure, And Aesthetics Element

\begin{tabular}{|c|c|}
\hline Goal, Objective, Policy, or Program & Finding of Conformity \\
\hline \multicolumn{2}{|l|}{$\begin{array}{l}\text { that reflects Patterson's small-town } \\
\text { qualities and agricultural heritage. }\end{array}$} \\
\hline $\begin{array}{l}\text { Policy VIII.A.3. The City shall use the } \\
\text { circulation system and the pedestrian } \\
\text { and bicycle pathway system as } \\
\text { important structural elements to link } \\
\text { and define neighborhoods and districts } \\
\text { in Patterson. }\end{array}$ & Supports bicycle and pedestrian pathways. \\
\hline $\begin{array}{l}\text { Policy VIII.A.4. The City shall promote } \\
\text { the development of a well-defined, } \\
\text { pedestrian-oriented downtown as the } \\
\text { center of Patterson's commercial, civic, } \\
\text { and cultural life. }\end{array}$ & Supports a walkable downtown. \\
\hline $\begin{array}{l}\text { Policy VIII.A.7. The City shall seek to } \\
\text { maintain a distinct agricultural } \\
\text { definition to the urban edge of the city } \\
\text { as a means of emphasizing } \\
\text { Patterson's small-town qualities and } \\
\text { agricultural heritage. }\end{array}$ & Supports agriculture. \\
\hline $\begin{array}{l}\text { Goal VIII.B. To create a well-defined, } \\
\text { pedestrian-oriented downtown which } \\
\text { serves as the center of Patterson's } \\
\text { commercial, civic, and cultural life. }\end{array}$ & $\begin{array}{l}\text { Supports a walkable downtown. } \\
\text { Note: Repeats Policy VIII.A.4. }\end{array}$ \\
\hline $\begin{array}{l}\text { Policy VIII.B.1. The City shall promote } \\
\text { the development of a well-defined, } \\
\text { pedestrian-oriented downtown by } \\
\text { preserving and enhancing the existing } \\
\text { downtown and by extending the grid } \\
\text { and radial street pattern of the existing } \\
\text { historic downtown to the west. The } \\
\text { downtown shall include commercial, } \\
\text { civic, residential, cultural, and } \\
\text { recreational uses, and shall serve all } \\
\text { segments of the community. The } \\
\text { commercial/civic core of downtown } \\
\text { shall be defined as the existing } \\
\text { downtown area focused on the circle } \\
\text { and its extension west along Las } \\
\text { Palmas Avenue to its planned } \\
\text { intersection with Sperry Avenue. The } \\
\text { existing downtown commercial/civic } \\
\text { core and its western expansion shall } \\
\text { be functionally and visually linked so } \\
\text { they operate to the maximum extent } \\
\text { possible as a single commercial/civic } \\
\text { district. }\end{array}$ & Supports a walkable downtown. \\
\hline $\begin{array}{l}\text { Policy VIII.B.3. The City shall } \\
\text { encourage the concentration and } \\
\text { intensification of urban uses, including } \\
\text { residential uses, in the downtown and } \\
\text { its western extension as a means of } \\
\text { increasing pedestrian activity and } \\
\text { providing support for commercial and } \\
\text { civic activities in the downtown. }\end{array}$ & $\begin{array}{l}\text { Supports downtown businesses, a walkable } \\
\text { downtown, compact growth, and infill } \\
\text { development. }\end{array}$ \\
\hline $\begin{array}{l}\text { Policy VIII.B.8. The City shall promote } \\
\text { the enhancement of the overall quality }\end{array}$ & Supports infill development. \\
\hline
\end{tabular}


Table B-7. City of Patterson General Plan City Design, Structure, And Aesthetics Element

Goal, Objective, Policy, or Program

of development along Highway 33 through infill and private and public redevelopment, as necessary.

\section{Finding of Conformity}

Analysis: This is one of the few policies (other than Policy V.D.2.) that directly address infill development. The implementation of this policy has the potential to increase the practice of infill development before greenfield development is allowed to occur.

Goal VIII.C. To preserve existing community character and fabric and promote the development of neighborhoods and districts that emphasize pedestrian convenience.

Policy VIII.C.2. The City shall promote the creation of well-defined residential neighborhoods in newly-developing areas. Each of these neighborhoods should have a clear focal point, such as a park, school, or other open space and community facility, and should be designed to promote pedestrian convenience. To this end, the City shall encourage the use of existing Patterson neighborhoods, including the grid street system, as models for the planning and design of new residential neighborhoods.

Policy VIII.C.3. New commercial and office development should promote pedestrian convenience, especially in the downtown and its western expansion. endeavor to protect the tree canopy created by mature trees in existing developed areas and in newly developing areas.

Policy VIII.D.2. The City shall require that all new development incorporate the planting of trees and other vegetation that extend the vegetation pattern of older adjacent neighborhoods into new development.
Supports pedestrian accessibility.

Supports walkable neighborhoods.

Supports a walkable downtown and pedestrian accessibility for other commercial and office areas.

Analysis: To a certain extent, this policy is not being implemented successfully, given the traditional strip mall-type development (not conducive to pedestrians, but rather cars) occurring in Patterson.

\section{Supports carbon sequestration and} improved air quality.

Recommendation: The City should adopt a tree preservation ordinance.

Supports carbon sequestration and improved air quality.

Analysis: Although the planting of trees may be occurring with new development, it takes several years for trees to mature in order to resemble any type of significant tree canopy for carbon sequestration and other objectives towards achieving a more sustainable Patterson. Moreover, the palm trees, while they are a tribute to Patterson's history and are aesthetically pleasing, they generally do not provide a great deal of ecological benefit, such as carbon sequestration to improve air quality, or 
Table B-7. City of Patterson General Plan City Design, Structure, And Aesthetics Element

\section{POTENTIALLY INCONSISTENT POLICIES}

The following policies are found to be inconsistent with measures to improve sustainability in Patterson.

Table B-8. City of Patterson General Plan

\begin{tabular}{l|l}
\hline Goal, Objective, Policy, or Program & \multicolumn{1}{|c}{ Finding of Conformity } \\
\hline $\begin{array}{l}\text { General Plan City Design, } \\
\text { Structure, And Aesthetics Element }\end{array}$ & \\
$\begin{array}{l}\text { Policy VIII.C.1. In approving new or } \\
\text { mull development, the City shall } \\
\text { respect existing neighborhood scale } \\
\text { and character. }\end{array}$ & $\begin{array}{l}\text { Does not support higher density, compact } \\
\text { growth. }\end{array}$ \\
\hline
\end{tabular}

\section{PATTERSON COMMUNITY DESIGN GUIDELINES (OCTOBER 2002)}

This 2005 APA award-winning document clearly states that Patterson "intends to maintain and enhance its present character as a compact community, with attractive and pedestrian-oriented commercial areas, welldesigned neighborhoods, and a vital downtown." The Community Design Guidelines promote a diversity of housing types, alternate modes of transportation, and a balanced mix of land uses, consistent with the City's 'Smart Growth' principles.

\section{STANISLAus COUNTY GENERAL PLAN (1994)}

The County General Plan begins to address the issue of sustainability, although not clearly stated as such. The lands designated for Agriculture "are of economic importance not only to Stanislaus County, but to the state and nation as well, as evidenced by the fact that Stanislaus County ranks very high nationally in production of agricultural commodities (p. 1-24). The Urban Transition designation is to ensure that land remains in agricultural usage until urban development consistent with a City's General Plan designation is approved (p. 1-24). Within the Land Use Element, there is explicit discussion of Source Reduction, Recycling and Composting, and Environmentally Safe Transformation and Landfilling (p. 1-97).

The Plan puts forth the following goals.

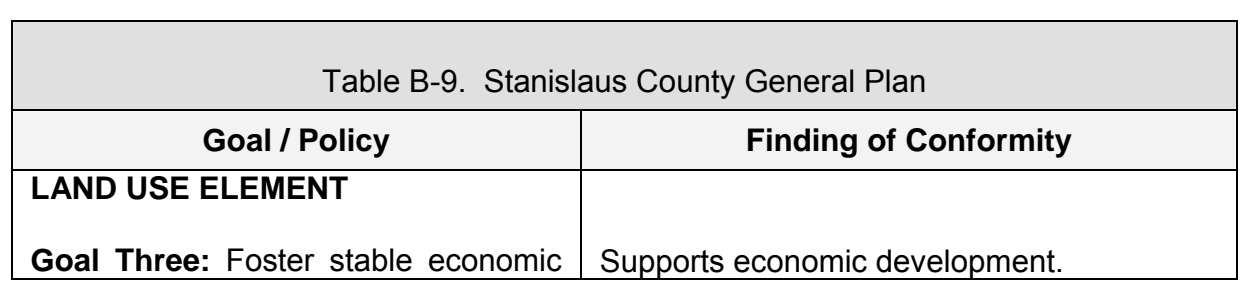

City of PATtERSON JUNE 2009 SUStAinABILITY PlaN 
Table B-9. Stanislaus County General Plan

\begin{tabular}{|l|l|}
\hline \multicolumn{1}{|c|}{ Goal $/$ Policy } & \multicolumn{1}{|c|}{ Finding of Conformity } \\
\hline $\begin{array}{l}\text { growth through appropriate land use } \\
\text { policies. }\end{array}$ & \\
\hline CIRCULATION ELEMENT &
\end{tabular}

Goal Two: Provide a safe, comprehensive, coordinated transportation system that includes a broad range of transportation modes. Goal Three: Maintain a balanced and efficient transportation system that facilitates inter-city and interregional travel and goods movement. CONSERVATION/OPEN SPACE ELEMENT

Goal One: Encourage the protection and preservation of natural and scenic areas throughout the County.

Goal Two: Conserve water resources and protect water quality in the County.

Goal Three: Provide for the long-term conservation and use of agricultural lands.

Goal Four: Provide for the openspace recreational needs of the residents of the County. Goal Six: Improve air quality. Goal Seven: Support efforts to minimize the disposal of solid waste through source reduction, reuse, recycling, composting and transformation activities.

Goal Ten: Protect fish and wildlife species of the County.

Goal Eleven: Conserve resources through promotion of waste reduction, reuse, recycling, composting, rideshare programs and alternative energy sources such as minihydroelectric plants, gas and oil exploration, and transformational facilities such as waste-to-energy plants.

AGRICULTURAL ELEMENT

Goal One: Strengthen the agricultural sector of our economy.

Goal Two: Conserve our agricultural lands for agricultural uses.

Goal Three: Protect the natural resources that sustain our agricultural industry.

Policy 2.3 To reduce development pressures on agricultural lands, higher
Supports walking, biking, and "Complete Streets."

Supports modes of transportation other than the private automobile. Supports regional transportation planning.

Supports protection of natural resources.

Supports water conservation.

Supports agricultural preservation.

Supports carbon sequestration, public health, and reduced obesity rates (implicitly). Supports improved air quality. Supports waste reduction, reuse, recycling, and composting.

Supports species and habitat protection.

Supports waste reduction, reuse, recycling, composting, and alternative energy sources.

Supports agriculture.

Supports agricultural preservation.

Supports agricultural preservation.

Supports infill development and agricultural preservation. 
Table B-9. Stanislaus County General Plan

\begin{tabular}{|c|c|}
\hline Goal / Policy & Finding of Conformity \\
\hline $\begin{array}{l}\text { density development and in-filling } \\
\text { shall be encouraged in urban and } \\
\text { built-up areas of the County. }\end{array}$ & \\
\hline $\begin{array}{l}\text { Policy } 2.4 \text { To the greatest extent } \\
\text { possible, development shall be } \\
\text { directed away from the County's most } \\
\text { productive agricultural areas. }\end{array}$ & Supports agricultural preservation. \\
\hline $\begin{array}{l}\text { Policy } 2.5 \text { New areas for urban } \\
\text { development (as opposed to } \\
\text { expansion of existing areas) shall be } \\
\text { limited to less productive agricultural } \\
\text { areas. }\end{array}$ & Supports agricultural preservation. \\
\hline $\begin{array}{l}\text { Policy 2.7 Proposed amendments to } \\
\text { the General Plan Diagram (map) that } \\
\text { would allow the conversion of } \\
\text { agricultural land to non-agricultural } \\
\text { uses shall be approved only if they } \\
\text { are consistent with the County's } \\
\text { conversion criteria. }\end{array}$ & Supports agricultural preservation. \\
\hline $\begin{array}{l}\text { Policy } 2.8 \text { The County recognizes the } \\
\text { right of cities and unincorporated } \\
\text { communities to grow and prosper and } \\
\text { shall not oppose reasonable requests } \\
\text { to expand spheres of influence of } \\
\text { cities or community services districts } \\
\text { and sanitary districts serving } \\
\text { unincorporated communities to } \\
\text { accommodate growth. }\end{array}$ & $\begin{array}{l}\text { Potentially impedes agricultural } \\
\text { preservation. }\end{array}$ \\
\hline $\begin{array}{l}\text { Policy } 2.9 \text { In recognition that } \\
\text { unincorporated land within spheres of } \\
\text { influence of cities or community } \\
\text { service districts and sanitary districts } \\
\text { serving unincorporated communities } \\
\text { ultimately will be urbanized, the } \\
\text { County shall cooperate with cities and } \\
\text { unincorporated communities in } \\
\text { managing development in urban } \\
\text { transition areas. }\end{array}$ & $\begin{array}{l}\text { Potentially impedes agricultural } \\
\text { preservation. }\end{array}$ \\
\hline $\begin{array}{l}\text { Policy } 2.11 \text { The County shall } \\
\text { discourage the expansion of spheres } \\
\text { of influence of cities or community } \\
\text { services districts and sanitary districts } \\
\text { serving unincorporated communities } \\
\text { into its most productive agricultural } \\
\text { areas. }\end{array}$ & Supports agricultural preservation. \\
\hline
\end{tabular}

COUNTY OF StANISLAUS VISIONING PROJECT 2000: CITIES/COUNTY VISION FOR THE NEW MILLENIUM

Published in January 2002, this document puts forth Vision statements, followed by related Actions for implementation.

\section{$\underline{\text { Land Use }}$}

Vision: We will demonstrate our resolve to produce a world class example of "DOING IT RIGHT" so that Stanislaus County remains blessed with a 
bounty of fertile land for agriculture. Population growth will be accommodated in communities of varying sizes ranging from larger metropolitan areas to mid-sized cities, to small rural towns and enclaves. Communities will plan, grow and evolve in a compact, efficient fashion. Large expanses of agricultural land and other open space will secure buffers between urban areas and preserve the beauty of views and vistas throughout the County.

Actions:

2. Protection of farmland outside the urban boundaries.

4. Compact urban development which encourages redevelopment of blighted areas, "in fill" development of vacant and underutilized land, and a variety of affordable housing.

5. Urban limit lines, providing for areas of open space, agriculture, very low density, rural development, or green belts in which urban development cannot occur.

\section{Environment}

Vision: Our precious natural resources will be used wisely. The air will be healthy to breathe, the water pure to drink and sufficient for our needs. We will enjoy an abundance of open space and a diversity of plant and animal life that is sustained in a variety of natural habitats.

Actions: The cities and County of Stanislaus will protect and enhance the environment by:

1. Restoration of riparian environments and preservation of river corridors for public access and use including regional park facilities and trail systems.

2. Ensuring that environmental policies affecting the region are developed with the involvement of local governments in Stanislaus County.

3. Protection, conservation and development of water resources for local domestic use and irrigation.

\section{Economy}

Vision: We will have a highly competitive, vibrant and diverse regional economy that provides economic opportunity for everyone close to home and results in both individual and regional prosperity.

Actions: A. The cities and County of Stanislaus will foster economic growth and develop a diversified economic base which provides maximum employment opportunities and jobs/housing balance, including:

4. A competitive workforce prepared to meet the needs of a world class economy.

6. Regional retail commercial centers along Highway corridors in urbanized areas.

7. Expansion of other major economic sectors which are compatible with agriculture. 
8. Development of freeway-oriented industrial and commercial uses in the I-5 corridor at the Patterson interchange to provide expanded employment centers for the residents of Stanislaus County.

9. Conversion of rural areas into large urban residential communities will be avoided. New residential development will be located within incorporated cities, Diablo Grande and other existing planned development communities.

Actions: B. The cities and County of Stanislaus will develop policies to maintain a strong agricultural economy including:

1. Preservation of farming, food processing and agricultural business services.

2. Ongoing research and analysis of the agriculture industry in order to sustain it as a major economic engine and source of employment.

\section{Transportation}

Vision: We will have an efficient, integrated transportation system that provides internal and external linkages and facilitates economic growth.

Actions: The cities and County of Stanislaus will develop a regional transportation system that will include the following:

1. A countywide expressway system with connector roads to provide access to other regions and to enhance mobility within Stanislaus County.

2. An efficient, well-coordinated countywide public transportation system. Bicycle and pedestrian trails linking neighborhoods and regional bikeways using existing public rights of way.

3. Development of the abandoned military airfield at Crows Landing, including air cargo facilities to expand the market for Stanislaus County agricultural products.

5. A system of rail passenger services including inter-urban light rail and access to interregional commuter rail services.

\section{Education}

Vision: Everyone, especially our children, will have opportunities to stimulate the mind, inspire the spirit and develop healthy bodies.

Actions: All the educational institutions of Stanislaus County will provide:

4. A workforce capable of meeting the needs of employers by providing graduates with core skills, a proper work ethic, and the ability to learn new skills.

5. Affordable and accessible continuing education programs for adults.

\section{Community}

Vision: Stanislaus County will contain diverse, interesting and unique social and cultural characteristics that strengthen the bonds within and between our communities, preserve local identity and enhance regional pride. Individuals and groups will commit to contributing to the well being of their community. 
Actions: The cities and County of Stanislaus will support local and regional cultural, library, recreation and parks facilities which provide a unique and rick quality of life, including:

1. A wide variety of cultural events, including the performing and visual arts, in modern facilities.

2. Community and regional facilities for community recreation including sports complexes for soccer, softball, baseball, track and field, etc.

\section{CONCLUSION}

The City of Patterson is already acting to improve sustainability, but there are numerous actions that can and should be added to the General Plan in order to combat climate change. The purpose of the proposed Sustainability Plan is to build on what policies already exist and lay out measures specifically aimed at achieving greater sustainability in Patterson, with the ability to measure progress. Of course, the easiest implementation measures, such as the elimination of conventional incandescent light bulbs in place of newer compact fluorescent lightbulbs (CFLs), are important to be implemented first, but there are many more actions that need to be implemented in order to be a sustainable community.

The City should encourage all of its employees, business owners, and residents to do everything in their power to promote only the best measures for mitigation, adaptation, and implementation in achieving greater sustainability.

The major areas in need of policy change are Land Use \& Community Design, Transportation, Waste Reduction \& $\&$ Recycling, Energy, Water, Air Quality, Natural Resources, Sustainable Economic Development, and Community Outreach \& Awareness. The City can and should focus its efforts on these areas, while continuing to improve on current practices set forth in the General Plan. The recommendations requiring the most attention in Patterson are the ones to achieve a jobs/housing balance, reduce the need for long-distance commuting to work, and the preservation of agricultural land.

City of PATTERSON JUNE 2009 SUSTAINABILITY PLAN 


\section{APPENDIX C ADDITIONAL ACTIONS FOR CONSIDERATION}

This Sustainability Plan recommends a range of actions to be implemented in the Near-Term (within five years of plan adoption) to improve sustainability in the City. However, the recommended Goals and Actions should not be considered an exhaustive list, nor an exclusive list. As stated in the Introduction, progress toward implementation will be reviewed annually to assess the effectiveness of the recommended actions and to take advantage of funding opportunities and improving technologies as they arise. In addition, achieving a greater measure of sustainability will necessarily involve a cooperative effort among federal, state, regional, and local governments and stakeholders. These cooperative efforts take time and effort to establish and are beyond the control of any single agency. With these constraints in mind, this Appendix contains additional Actions for the City to consider in the future.

\section{LAND USE \& TRANSPORTATION}

Goal: $\quad$ Preserve agriculture and agriculture-related operations as an important industry within and around Patterson, and protect agricultural land from urban development.

\section{Potential Additional Actions}

Collaborate with Stanislaus County to encourage lot mergers and consolidations within Agricultural zoning districts and among properties seeking inclusion into Agricultural districts to meet minimum parcel requirements for Williamson Act participation.

Issues:

City does not have direct authority over land use in the unincorporated County.

Achieve $80 \%$ of Williamson Act enrollment for qualified Agriculturedesignated properties that are otherwise not protected in perpetuity. An inventory of parcels under a Williamson Act contract and those with easements within the City shall be maintained by the Community Development Department and the status of those contracts/easements reported to the Planning Commission and City Council.

Issues:

City does not have direct authority over land use in the unincorporated County.

Coordinate with Stanislaus County to adopt a similar agricultural mitigation ordinance with permanent replacement of agricultural land with equal quality at a l:l ratio.

Issues:

City does not have direct authority over land use in the unincorporated County. 
Amend Municipal Code to require the development of vacant and underutilized land (infill growth) within City limits before annexing agricultural land or allowing outward expansion of urban limits. If vacant and underutilized land within the City is unavailable, develop agricultural land within the City before annexing agricultural land or allowing outward expansion of urban limits.

Explanation:

Similar Action is included in General Plan Update.

Amend Municipal Code to require new development to dedicate land for the buffer. Consider an in-lieu fee option.

Explanation:

This Action should be considered for later phasing.

The City should purchase contiguous tracts of agricultural land surrounding the City limits to ensure agricultural uses remain and land is protected from urban development.

Explanation:

This Action is one possible strategy for establishing an agricultural buffer around the City, and should be considered for later phasing.

Goal: $\quad$ Improve fuel efficiency of the City's Vehicle Fleet.

\section{Potential Additional Actions}

Reduce City fleet fuel consumption by $15 \%$ by 2012, relative to baseline year of 2010.

\section{Explanation:}

This Action should be considered for inclusion in the Climate Action Plan, or considered for later phasing in the PSP.

Explore alternative options for police patrolling units in Downtown and security at special events.

\section{Explanation:}

This Action should be considered for inclusion in the Climate Action Plan, or considered for later phasing in the PSP.

The City should utilize battery-operated personal mobility vehicles (e.g. Segways) and "cops on bikes."

\section{Explanation:}

This Action should be considered for inclusion in the Climate Action Plan, or considered for later phasing in the PSP. 
Goal: $\quad$ Improve fuel efficiency community-wide.

\section{Potential Additional Actions}

Encourage Patterson Joint Unified School District (PJUSD) to convert school buses to cleaner, more efficient vehicles such as electric, hybrid, or alternative fuels, and explore the option of de-commissioning all school buses, encouraging students to walk or bicycle instead.

Issues:

City does not have direct authority over the school district.

Encourage Stanislaus Regional Transit (StaRT) to convert 100\% of public transit vehicles to cleaner, more efficient vehicles such as electric, hybrid, or alternative fuels.

Issues:

City does not have direct authority over the regional transit agency.

Goal: $\quad$ Increase the use of alternative modes of transportation by City employees and employees of commercial and industrial businesses.

\section{Potential Additional Actions}

Create a friendly competition with neighboring cities by measuring the number of cars taken off the road.

Explanation:

This Action should be considered for inclusion in the Climate Action

Plan, or considered for later phasing in the PSP.

Encourage the use of Global Electric Motorcars (GEM) or Segways (batteryoperated personal mobility vehicles) for utility readings and mail delivery.

Issues:

City does not have direct authority over TID, PG\&E,

FedEx, UPS, or the U.S. Postal Service.

Goal: $\quad$ Increase the use of alternative modes of transportation by the general public.

\section{Potential Additional Actions}

Encourage the Patterson Joint Unified School District (PJUSD) to establish a school ridesharing program.

Issues:

City does not have direct authority over the school

district. 
Implement a "Safe Routes to School" Program.

Issues:

City does not have direct authority over the school district.

Goal: $\quad$ Promote increased public transit ridership.

\section{Potential Additional Actions}

Encourage Stanislaus Regional Transit (StaRT) to provide frequent shuttle service for special events (e.g. Apricot Fiesta).

Issues:

City does not have direct authority over the regional transit agency.

Encourage Stanislaus Regional Transit (StaRT) to provide shuttle service to international airports: Sacramento, Oakland, and San Jose.

Issues:

City does not have direct authority over the regional transit agency.

\section{ENERGY}

Goal: Incorporate sustainable building practices into the City's development regulations.

\section{Potential Additional Actions}

Encourage new school construction to achieve a LEED Silver rating. Issues:

City does not have direct authority over the school district.

Require materials of a high Solar Reflectance Index for cool roofs and roads, and the use of paving materials and open grid paving in parking lots and driveways.

\section{Explanation:}

This Action should be considered for inclusion in the Climate Action Plan, or considered for later phasing in the PSP.

CITY of PATTERSON JUNE 2009 SUSTAINABILITY PLAN

$$
\text { C-4 }
$$


Goal: $\quad$ Promote the development of on-site renewable energy (e.g. solar, wind, biomass, and geothermal).

\section{Potential Additional Actions}

Develop a City-wide renewable energy GIS database identifying potential sites for renewable energy projects.

Collaborate with the California Energy Commission (CEC) and the EPA to create wind and solar feasibility maps identifying the renewable energy potential by individual parcel.

Designate a City staff-member to act as a Renewable Energy Broker between private property owners interested in hosting renewable energy installation and third party energy producers/investors, using the database to locate potential sites.

\section{Explanation:}

This Action should be considered for inclusion in the Climate Action Plan, or considered for later phasing in the PSP.

Goal: $\quad$ Increase public awareness of energy-saving measures.

\section{Potential Additional Actions}

Encourage TID and PG\&E to include information in electronic billing notices, about measures to improve energy efficiency, reduce energy use, and the benefits of renewable energy.

Issues:

City does not have direct authority over TID or PG\&E.

Implement the "Change a Light Campaign" distributing two Compact Fluorescent Light (CFL) bulbs to each household to illustrate how simple and cost-effective energy efficiency measures can be.

\section{Explanation:}

This Action was omitted due to funding scarcity, and in favor of Outreach \& Awareness measures, but it should be considered for later phasing.

Encourage Energy Star office equipment (e.g. computers, monitors, printers, copiers, fax machines).

\section{Explanation:}

This Action should be included in the Green Business Certification requirements. 


\section{WAste REDUCTION \& RECYCLING}

Goal: $\quad$ Reduce the generation of solid waste from City operations.

\section{Potential Additional Action}

Support Producer Responsibility through the California Product Stewardship Council, where manufacturers are responsible for disposal of any toxic products produced and initiating product take-back programs.

Issues:

City does not have direct authority over manufacturers.

Goal: $\quad$ Increase public awareness of waste reduction and recycling.

\section{Potential Additional Actions}

Establish Outstanding Recycler Awards as a friendly competition among apartment complexes, and among schools, similar to Recycle Rex's Statewide Challenge. Collect aluminum and plastic CRV beverage containers from home, school, and neighbors.

Issues:

City does not have direct authority over management

of apartment complexes.

Create a City-wide recycled art contest. Winning pieces will be displayed at City Hall and other public facilities.

Explanation:

This Action should be considered for later phasing.

\section{WATER}

Goal: $\quad$ Reduce overall municipal water use.

\section{Potential Additional Action}

Meet all new demand through water conservation.

Explanation:

This Action should be considered for later phasing. 


\section{PUBLIC HEALTH}

Goal: $\quad$ Reduce air pollution and greenhouse gas (GHG) emissions.

\section{Potential Additional Actions}

Offer carbon neutral services to all water and solid waste customers.

\section{Explanation:}

This Action should be considered for inclusion in the Climate Action Plan.

Collaborate with Stanislaus County and the San Joaquin Valley Air Pollution Control District to evaluate the effects of the Fink Road Waste-to-Energy Plant on air quality. Explore the feasibility of alternatives and decommission. Develop facilities to convert refuse to energy without incineration.

\section{Explanation:}

Though the Fink Road Waste-to-Energy Facility is considered an asset in the June 2009 version of the Sustainability Plan, given its status as renewable energy, this Action should be considered for later phasing to improve air quality.

Amend Municipal Code to require the use of $\mathrm{CO}_{2}$-absorbing cement (e.g. cement using blast-furnace slag).

\section{Explanation:}

This Action should be considered for inclusion in the Climate Action Plan, or considered for later phasing in the PSP.

Goal: $\quad$ Establish and maintain a healthy urban forest.

\section{Potential Additional Action}

Plant trees, flowers, and foliage to complement the lawn at the stormwater retention basin in the West Patterson Business Park.

Explanation:

This Action should be considered for later phasing.

Goal: Improve the availability and access to local food sources.

\section{Potential Additional Action}

Impose a moratorium on fast-food restaurants and improve access to restaurants with healthier eating options.

Explanation:

This Action should be considered for later phasing. 


\section{SUSTAINABLE ECONOMIC DEVELOPMENT}

Goal: Increase public awareness of Green Businesses.

\section{Potential Additional Actions}

Amend Municipal Code to allow incidental retail/visitor-serving uses in Agricultural areas to promote direct marketing and diversification (e.g sale of local produce at fruit \& vegetable stands). Encourage and promote ecotourism and farm tourism (e.g. U-pick apricots and pumpkins, farm animals, hayrides, horse ride tours informing people about the history of agriculture in Patterson).

\section{Issues:}

City does not have direct authority over land use in the unincorporated County.

Encourage businesses to consider the impact of their location when expanding or moving. Locate businesses on sites in close proximity to transit stops and business centers to enable employees and customers to walk, bike, or take transit.

Explanation:

This Action should be considered for inclusion in the Climate Action Plan, or considered for later phasing in the PSP.

\section{OUTREACH $\&$ AWARENESS}

\section{Goal: Increase public awareness of measures to improve sustainability.}

\section{Potential Additional Actions}

Establish an annual "Sustainable Subdivisions" friendly competition to encourage residents to be more green than their neighbors.

Explanation:

This Action should be considered for later phasing.

Collaborate with HOAs and other community organizations to conduct multi-lingual outreach. Provide presentations to neighborhood groups, businesses, and community organizations to inform them of the actions the City is taking and what they can do to help.

Explanation:

This Action should be considered for later phasing.

Encourage the Kiwanis Club, Lions Club, Rotary Club, Soroptomist Club, Helping our Westside (HOW), the Chamber of Commerce, and other community organizations to spread awareness about sustainability.

Issues:

City does not have direct authority over community

organizations.

City of PATTERSON JUNE 2009 SUSTAINABILITY PLAN 


\section{TIPS TO BE SUSTAINABLE}

Many Actions that are too specific for inclusion in the Patterson Sustainability Plan should be made available on the City's new Sustainability Webpage, as "Tips to Be Sustainable." Some examples are shown below:

\section{LAND USE \& TRANSPORTATION}

1. Choose not to own a vehicle or drive less.

2. Use public transit or ride-share.

3. Walk, jog, bicycle, in-line skate, or skateboard (getting exercise at the same time), or use an electric scooter or Segway to travel to work, to a friend's home, and to events.

4. Shop close to home or work and combine errands into one trip.

5. Share the road. Get respect on the road. When driving, be aware of your surroundings. Check for bicyclists before merging or turning right.

6. Keep your vehicle properly maintained by getting regularly scheduled maintenance and keeping your tires inflated.

7. Check your air filter monthly. With an old air filter, your vehicle emits more carbon dioxide than with a new one and uses more energy.

8. Drive the speed limit and maintain a steady speed to save gas and reduce carbon emissions.

\section{ENERGY}

1. Replace incandescent light bulbs with energy-efficient or LED bulbs.

2. Take shorter showers and wash clothes in cold water.

3. Purchase more energy-efficient windows and appliances (Energy Star).

4. Increase insulation (walls, windows, doors, skylights, attic/roof).

5. Properly program home thermostats. Thermostats should not exceed 68 Degrees for heating and 75 degrees for cooling (California Energy Commission).

6. Set the water heater (the home's second largest energy user) to 120 degrees.

7. Keep the refrigerator and freezer away from heat sources. Set the refrigerator at 35 to 38 degrees and the freezer at zero for maximum efficiency. Clean coils and rubber door seals regularly.

Did you know?

Heating the water for a shower that uses an average of 2.5 gallons per minute produces 3 ounces of carbon dioxide per gallon. Showering 2 minutes less per day would result in a reduction of 342 pounds of carbon dioxide emissions per year. - stopglobalwarming.org The Energy Diet, Andrew Postman, October 5 , 2006

8. Purchase the most energy efficient appliances (Energy Star), including equipment that uses hot water more efficiently. 
9. Properly maintain your heating and cooling system to save energy and improve efficiency (i.e. HVAC units). Clean filters and perform a professional check-up every two years.

10. Plant trees that provide shade in summer and sun in winter to reduce heating and air conditioning energy use.

11. Open your windows instead of turning on the air conditioning.

12. Lower the brightness of your computer screen.

13. Only use the lights you need. Turn lights off when you leave the room.

14. Turn off (and unplug) electronics and appliances (e.g. computers, cell phone chargers) when you're not using them.

15. Limit the use of holiday lights (one week or less per year).

\section{WAste Reduction \& RECYCLING}

1. Use environmentally-friendly and rapidly renewable products. Use wood alternatives or FSC-certified wood products. Use flooring products of bamboo, cork, or eucalyptus that grow rapidly.

2. Utilize double-sided printing.

3. Use FSC-certified 100\% Post-Consumer Recycled Paper.

4. Avoid purchasing over-packaged goods.

5. Purchase a reusable BPA-free water bottle. They can be made from polylactic acid (PLA), a biodegradable (compostable) material derived from renewable resources, such as corn starch, eliminating the danger of being exposed to harmful toxic chemicals that are found in today's plastic bottles.

6. Compost your food scraps.

7. Avoid purchasing or using unnecessary plastic, such as individual water bottles and plastic bags.

8. Use a reusable cloth bag for your shopping instead of disposable plastic bags.

\section{WATER}

1. Use water-efficient dishwashers and washing machines, and run them only when full.

2. If you have a newer dishwasher, don't pre-rinse the dishes.

3. Take shorter showers.

4. Turn off the water while you're brushing your teeth or shaving.

City of PATterson JUNe 2009 SUStAINABILITY PLAN 


\section{PUBLIC HEALTH}

1. Use low-emission and environmentally-friendly carpet, sealants, adhesives, cleaning products, paint, flooring, fabrics, and home \& office furnishings, i.e. with Low Volatile Organic Compound (VOC) production.

2. Purchase organic food. The chemicals used in much of modern agriculture pollute the water supply and require energy to produce.

3. Buy locally grown produce. It's fresh and has traveled less, thus reducing greenhouse gas emissions. Support your local farmers!

4. Plant a tree to help clean the air. 



\section{APPENDIX D. GLOSSARY}

\section{DEFINITIONS}

alternative fuel vehicle - a vehicle that runs on a fuel other than traditional petroleum fuels (gas or diesel)

alternative modes of transportation - transportation by public transit (bus or rail), bicycle, walking, or using electric, hybrid, or alternative fuel vehicles

biodiesel - a renewable non-petroleum fuel produced from crops such as soy and canola, or used cooking oils and unwanted animal fats; in its life cycle, biodiesel produces 78 percent less carbon dioxide than petroleum diesel; biodiesel can be blended at any level with petroleum diesel but is most commonly found at a ratio of 20 percent biodiesel to 80 percent diesel (B20); biodiesel costs about the same as petroleum diesel and is becoming more widely available at retail and bulk fueling stations

biomass - organic matter that can be used to produce energy; can also be converted directly into a combustible gas, allowing for greater efficiency and cleaner performance

climate change - a global, human-induced problem with local consequences for sustainability; characterized by rising temperatures (global warming), and known to be primarily caused by greenhouse gas emissions from vehicles, buildings, power plants, and other manmade sources - rather than natural variations in climate (PEW Center on Global Climate Change)

cool roof - using materials of a high Solar Reflectance Index (light colors reflect heat and sunlight) to reduce the surface temperature by up to 100 degrees Fahrenheit (California Energy Commission), thereby reducing the heat transferred into the building below, which reduces energy costs (by keeping attics and ducts cooler), improves occupant comfort, cuts maintenance costs, increases the life cycle of the roof, and reduces the Urban Heat Island Effect along with associated smog

flex-fuel vehicle - an alternative fuel vehicle designed to run on more than one fuel

Food Systems Plan - planning for local/decentralized, sustainable food production, processing, distribution/purchasing, and composting food waste

geothermal energy - generated by converting hot water or steam from deep beneath the Earth's surface into electricity; geothermal plants emit very little air pollution and have minimal impact on the environment

greenhouse gas (GHG) emissions - the primary cause for the greenhouse effect, contributing to global warming (rising temperatures) and climate change; primarily from vehicles, buildings, power plants, and other man-

CITY OF PATTERSON JUNE 2009 SUSTAINABILITY PLAN 
made sources (PEW Center on Global Climate Change 2009); examples include carbon dioxide, methane, nitrous oxide, ozone, and chlorofluorocarbons

GreenPoint Rated (Build It Green) - residential buildings are graded on five categories:

1. Resource Conservation

2. Indoor Air Quality

3. Water Conservation

4. Community

5. Energy Efficiency

graywater - the majority of residential wastewater other than from the toilet; from dish washing, laundry, and bathing; this untreated wastewater can be used safely and effectively for irrigation where potable water is not required; graywater diverted from wastewater systems can be designed into new homes, or retrofitted in existing homes. Stormwater harvest (e.g. installation of cisterns on roof downspouts) also provide a water source for yard watering that does not require delivery of treated water

green roof - a permanent planting system with live plants covering a significant portion of a building's roof

hybrid vehicle - has an engine that runs on both electricity and conventional gas

LEED (Leadership in Energy and Environmental Design) quantitatively rates buildings by the impact on the current and future environment. Its requirements for both residential and non-residential development will change, continuously becoming more stringent as technology improves. The program evaluates numerous aspects of building programs including the following:

- Site Selection

- Brownfield Development

- Transit-oriented Development

- Maximization of Open Space

- Stormwater Management

- Heat Island Effects

- Light Pollution Reduction

- Efficient Water Usage in Structures

- Efficient Water Usage in Landscaping

- Innovative Wastewater Technologies

- Energy Conservation

- Construction Waste Management

- Implementation of Ongoing Recycling Programs

- Use of Recycled, Renewable, and/or Locally Produced Building Materials 
recycled water - treated wastewater that is reused to irrigate parks and other landscaping

sector - residential, commercial, industrial, or government

solar power - photovoltaic cells, which are made of silicon, convert the sun's (renewable) energy into electricity, providing a clean form of energy to feed electricity into the grid

\section{sustainability}

sustainable/green - a method of using a resource so that resource is not depleted or permanently damaged

sustainable business - provides goods and services, and/or has incorporated into its daily operations practices that result in cleaner air and water, less waste and pollution, conservation of energy and natural resources, less traffic, improved quality of life for residents and workers, and contributes to a strong and viable local economy sustainable community/city - a community or city that meets it present needs without sacrificing the ability of future generations to meet their own needs; improves and enhances its natural, social, and economic resources in ways that allow current and future members of the community to lead healthy, productive, and satisfying lives sustainable procurement/purchasing - procurement of environmentally preferable goods and services in a way that also takes into consideration social responsibility and sustainable economic development issues in the manufacture, transportation, sale and use of those goods and services

Transfer of Development Rights (TDR) program - a voluntary, incentivebased, and market-driven approach to preserve land and relocate development growth away from rural areas into existing urban areas

urban heat island - created by urban development in rural areas and waste heat from energy usage; can increase air temperatures and the intensity of heat waves, causing what is known as the Urban Heat Island Effect contributing to smog, alters local wind patterns, the rainfall pattern, and the plant-growing season; on warm summer days, a city can be 6-8 ${ }^{\circ} \mathrm{F}$ warmer than its surrounding areas (Akbari 2000)

zero waste - extends current approaches to recycling by introducing the concept of "cradle-to-grave" where as much waste as possible is reused, similar to the way resources are reused in nature

CITY OF PATTERSON JUNE 2009 SUSTAINABILITY PLAN 


\section{ACRONYMS}

\begin{tabular}{|c|c|}
\hline $\mathrm{AB}$ & Assembly Bill \\
\hline ACWA & Association of California Water Agencies \\
\hline \multicolumn{2}{|c|}{$\begin{array}{c}\text { ATSAC Automated Traffic Signal Synchronization and } \\
\text { Control System }\end{array}$} \\
\hline BMPs & Best Management Practices \\
\hline BPA & Bisphenol-A \\
\hline CARB & California Air Resources Board \\
\hline CAP & Climate Action Plan \\
\hline CCAR & California Climate Action Registry \\
\hline $\mathrm{CCP}$ & Cities for Climate Protection \\
\hline CEC & California Energy Commission \\
\hline CEQA & California Environmental Quality Act \\
\hline CFL & Compact Fluorescent Lamp \\
\hline CNG & Compressed Natural Gas \\
\hline $\mathrm{CO}_{2}$ & Carbon Dioxide \\
\hline CPUC & California Public Utilities Commission \\
\hline \multicolumn{2}{|c|}{ CREECCalifornia Regional Environmental Education } \\
\hline & Community \\
\hline CUWCC & California Urban Water Conservation Council \\
\hline CVP & Federal Central Valley Project \\
\hline CYES & California Youth Energy Services \\
\hline DHS & California Department of Health Services \\
\hline DMC & Delta Mendota Canal \\
\hline $\mathrm{EE}$ & Environmental Education \\
\hline EEI & Education and the Environment Initiative \\
\hline EIR & Environmental Impact Report \\
\hline EPA & Environmental Protection Agency \\
\hline FAR & Floor Area Ratio \\
\hline FSC & Forest Stewardship Council \\
\hline GHG & Greenhouse Gas \\
\hline gpm & gallons per minute \\
\hline GVC & Great Valley Center \\
\hline HHW & Household Hazardous Waste \\
\hline HBANC & $\begin{array}{l}\text { Home Builders Association of Northern } \\
\text { California }\end{array}$ \\
\hline $\mathrm{HOA}$ & Homeowners Association \\
\hline HVAC & Heating, Ventilating, and Air Conditioning \\
\hline ICLEI & Local Governments for Sustainability \\
\hline kw & kilowatt \\
\hline OLED & Organic Light-Emitting Diode \\
\hline LED & Light-Emitting Diode \\
\hline LEED & Leadership in Energy and Environmental Design \\
\hline \multicolumn{2}{|c|}{ LGSEC Local Government Sustainable Energy Coalition } \\
\hline LOS & Level of Service \\
\hline mpg & miles per gallon \\
\hline MPO & Metropolitan Planning Organization \\
\hline MRF & Materials Recovery Facility \\
\hline MW & Megawatt \\
\hline
\end{tabular}

CITY of PATTERSON JUNE 2009 SUSTAINABILITY PLAN

D-4 


$\begin{array}{ll}\text { MWh } & \text { Megawatt hours } \\ \text { NCLB } & \text { No Child Left Behind Act } \\ \text { PG\&E } & \text { Pacific Gas \& Electric } \\ \text { PJUSD Patterson Joint Unified School District } \\ \text { PLA } & \text { Polylactic Acid } \\ \text { PM } & \text { Particulate Matter } \\ \text { PSP } & \text { Patterson Sustainability Plan } \\ \text { PV } & \text { Photovoltaic } \\ \text { RHNA } & \text { Regional Housing Needs Allocation } \\ \text { RPS } & \text { Renewable Portfolio Standard } \\ \text { RTP } & \text { Regional Transportation Plan } \\ \text { SB } & \text { Senate Bill } \\ \text { SCS } & \text { Sustainable Communities Strategy (SB 375) } \\ \text { SDWA } & \text { Federal Safe Drinking Water Act } \\ \text { SJVAPCD } & \text { San Joaquin Valley Air Pollution Control District } \\ \text { SRRF } & \text { Stanislaus Resource Recovery Facility } \\ \text { StanCOG } & \text { Stanislaus Council of Governments } \\ \text { StaRT } & \text { Stanislaus Regional Transit } \\ \text { TDR } & \text { Transfer of Development Rights } \\ \text { TID } & \text { Turlock Irrigation District } \\ \text { TOD } & \text { Transit-Oriented Development } \\ \text { USGBCUnited States Green Building Council } \\ \text { UWMP } & \text { Patterson Urban Water Management Plan } \\ \text { VMT } & \text { Vehicle Miles Traveled } \\ \text { WQCF } & \text { Water Quality Control Facility } \\ \text { WPS } & \text { City of Patterson 2006 Water Planning Study } \\ \text { WTE } & \text { Waste-to-Energy Facility } \\ & \end{array}$

CITY OF PATTERSON JUNE 2009 SUSTAINABILITY PLAN 